

\section{DISCLAIMER}

This report was prepared as an account of work sponsored by an agency of the United States Government. Neither the United States Government nor any agency Thereof, nor any of their employees, makes any warranty, express or implied, or assumes any legal liability or responsibility for the accuracy, completeness, or usefulness of any information, apparatus, product, or process disclosed, or represents that its use would not infringe privately owned rights. Reference herein to any specific commercial product, process, or service by trade name, trademark, manufacturer, or otherwise does not necessarily constitute or imply its endorsement, recommendation, or favoring by the United States Government or any agency thereof. The views and opinions of authors expressed herein do not necessarily state or reflect those of the United States Government or any agency thereof. 


\section{DISCLAIMER}

Portions of this document may be illegible in electronic image products. Images are produced from the best available original document. 
$\mathrm{APL} / \mathrm{JHU}$

QM-79-261

DECEMBER 1979

\title{
Geothermal Energy And The Eastern U.S.
}

Technical Information Interchange Meeting

\section{MINUTES}

\author{
Prepared by: THE JOHNS HOPKINS UNIVERSITY \\ APPLIED PHYSICS LABORATORY \\ For the: DIVISION OF RESOURCE MANAGEMENT \\ RESOURCE APPLICATIONS \\ U.S. DEPARTMENT OF ENERGY
}

THE JOHNS HOPKINS UNIVERSITY a APPLIED PHYSICS LABORATORY Johns Hopkins Road, Laurel, Maryland 20810 


\section{PREFACE}

The technical interchange meeting documented here is the fourth meeting where people interested in geothermal energy in the Eastern U.S. have met to interchange technical information. These meetings are Intended to assist a 11 in the difficult task of balancing time and effort in doing their assigned jobs and keeping track of what others are doing in similar or related tasks o $A 11$ of the a forementioned meetings have served their intended purpose and further regional and nationa meetings are sure to follow.

We thank those who attended the meeting and presented summaries of their work particular recognition is due Mr. R. A,Black, Dr, G, P.Brophy, and Mr. B, B. Barnes of the Department of Energy who assisted in the organization of the meeting and contributed to its success.

The coolfont Convention Center provided a pleasant setting and very adequate facilities for the meeting. The able assistance of Mrs. Sharon Ryan is acknowledged for those arrangements. The very capable receptionist at the meeting was Mrs. Janice Eisner from the Berkeley Springs area.

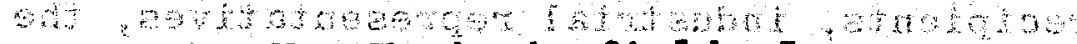

-Mr.W. A. Armfield,Jr. gave a most interesting ta1k

on the evening of 30 october on the mechanics of raising venture capital for oll and gas exploration Mr. Armfield briefly discussed whether and when these techniques will apply to geothermal energy development in the Eastern U.S.

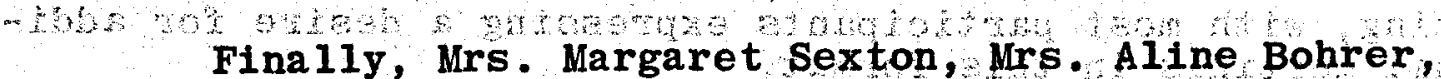
Mrs. Carolyn Silas, and Mr. William B. Chapman of The Johns Hopkins University Applied Physics Laboratory very capably took care of the myriad of items required to hold the meeting and to issue these minutes in a minimum of time.

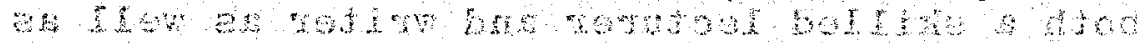

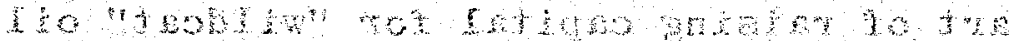

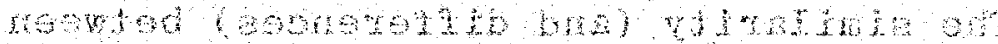

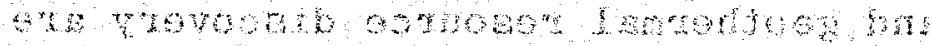

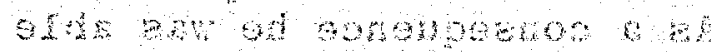

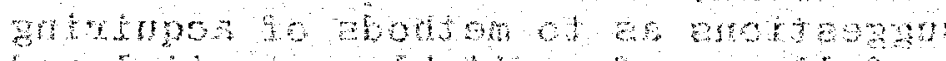

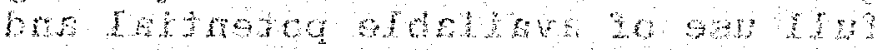

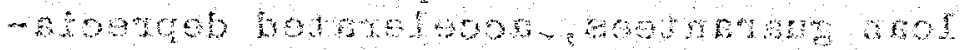

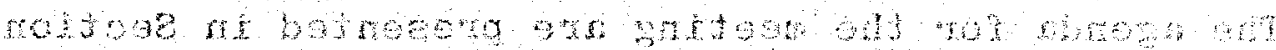




\section{INTRODUCTION}

The Technical Information Interchange Meeting, held at Berkeley Springs, West Virginia, on October 30-31, 1979, was the fourth in a series, each under separate auspices.

The first information interchange meeting on Eastern geothermal programs, the Near-Normal Gradient Workshop, was held in March 1975 under the aegis of the Energy Research and Development Administration. The second Technical Information Meeting was held at the Applied Physics Laboratory in September 1978 under the auspices of the Division of Geothermal Energy; Department of Energy (DOE). A symposium on Geothermal Energy and Its Direct Use in the Eastern United States was sponsored by the Geothermal Resources Council in Roanoke, Virginia in April 1979. This, the fourth such meeting, was sponsored by the Division of Geothermal Resource Management, DOE.

The fifty-four attendees represented DOE/DGE, DOE/RA, U.S. Geologic Survey, state geologic offices, state energy. offices, DOE Regional Offices, Program Research and Development Announcement (PRDA) recipients, industrial representatives, the national laboratories, and interested county officials (see Section XXX for the list of attendees). Virtualiv all attendees participated in the program, summarizing their efforts in promoting the use of geothermal energy in the East. By all accounts this was an enthusiastic and successful interchange meeting, with most participants expressing a desire for additional meetings in this format.

In the evening of the first day, an informal talk was given by Mr. W. A. Armfield, Jr., of The Armfield Organization, Inc., investment banking services, of Winston-Salem, North Carolina, who is both a skilled lecturer and writer as well as a practioner in the art of raising capital for "wildcat" oil and gas ventures. The similarity (and differences) between oil-well wildcatting and geothermal resource discovery are well understood by Mr. Armfield. As a consequence he was able to put forth several suggestions as to methods of acquiring venture capital, making full use of available potential and prospective tax credits, loan guarantees, accelerated depreciation, etc.

$\mathrm{XXX}$.

The agenda for the meeting are presented in Section 
THE JOHNS HOPKINS UNIVERSITY

APPLIED PHYSICS LABORATORY

LAUREL MAaYLAND

During the first morning, an overview of the current programs of DGRM/RA and DGE/DOE was presented, as well as a review of the Eastern geothermal resources by the DGE contractors, Gruy Federal and Virginia Polytechnic Institute and State University. The Eastern Hot Dry Rock program has already begun, with a number of holes drilled, as reported by Los Alamos Scientific Laboratory. Other Eastern programs in early stages were presented, notably that of the Oak Ridge Energy Analysis Institute for the Tennessee valley Authority region.

Of major interest were the discussions on the first DOE/DGE deep weIl in the East in Crisfield, Maryland. Details of the well performance and possible applications were presented by the Maryland State Geologist and by the Applied Physics Laboratory.

The first day concluded with several applications papers, notably one on geothermal vaporization of liquified natural gas (LNG) at Cove Point, Maryland, by the Columbia Gas Company, and one on a geothermal market assessment of the Atlantic Coastal Plain by the Applied Physics Laboratory.

The second day was devoted to reports on geothermal studies in the Eastern states, given principally by the respective state geologic surveys in the states of Delaware, Alabama, Mississippi, and Kansas, by New York State Energy Research and Development Administration (NYSERDA) and its contractors for New York state, and by the University of West Virginia and the University of Nebraska for their respective states.

These Minutes of the Technical Interchange Meeting consist of the textual and illustrative material as furnished by each speaker*. No attempt has been made by the editor to do more than ensure legibility and therefore the responsibility for the content lies with the individual authors. Fur thermore, correspondence with regard to any paper should be addressed to each author, respectively. The primary distribution of these Minutes is being made to the list of invitees to the meeting. Additional copies may be had on application to the Applied Physics Laboratory, Attn: Mr. William B. Chapman.

* In one or two cases, as indicated in the appropriate text, the material was assembled by $A P L / J H U$ from the author's notes or telephoned information. 


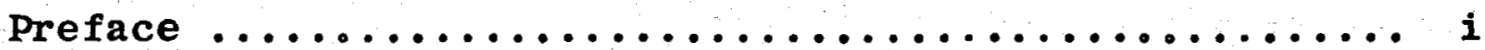

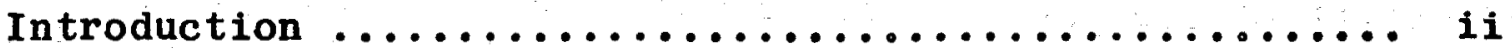

Table of Contents $\ldots \ldots \ldots \ldots \ldots \ldots \ldots \ldots \ldots \ldots \ldots \ldots \ldots \ldots$

I Summary of DOE Geothermal Programs .......... R. A. Black

II Federal/State Geothermal Planning and Project

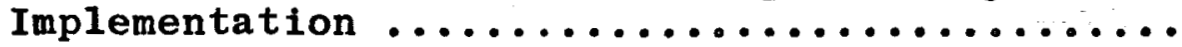
B. B. Barnes

II Summary Description of the DOE/DGE State Coupled

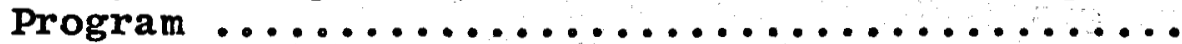
G. P. Brophy

IV Future Directions in the Direct Heat Applications Program

M. Ska lka

V Status of Federal Legislation of Interest to Geothermal Energy Development ............ R. C. Stephens

VI Preliminary Definition of Selection Geothermal Resources, Eastern U.S. ................ J. L. Renner

VII Mid-Atlantic and Southeastern Moderate Temperature Program - Geologic Setting and Targeting Process

VII The Hot Dry Rock - Eastern Program .......... J. C. Maxwe11

IX Geothermal Application Assessment for the TVA Region

C. E. Whittie

$X$ The MITRE Programs in Support of Geotherma1 Development

$$
\text { D. Entingh }
$$


The Crisfield We11, Somerset County, Maryland .. K. Schwarz

XIII Analysis of Test Data from DOE Crisfield Airport No. 1 Well

J. H. Hartsock

XIV Crisfield Well Characteristics Determined Using A11 Test Data

K. Yu

XV Geothermal Heating for the Crisfield, Maryland High School

F. C. Paddison

XVI Status Report Engineering and Economics Studies; Direct Application of East Coast Geothermal Resources in the Frozen Food Industry

$$
\begin{aligned}
& \text { R. Costelio and } \\
& \text { M. Knebel }
\end{aligned}
$$

XVII ING Vaporization at Cove Point, Maryland with Geothermal Energy

$$
\text { A. B. Litchfield }
$$

XVIII Geothermal Development Program, Department of Defense

$$
\begin{aligned}
& \text { T. A. Ladd and } \\
& \text { C. F. Austin }
\end{aligned}
$$

XIX Geothermal Energy Market Assessment, Atlantic Coastal plain

W. J. Toth

XX Comparison of Potential Geothermal Resources; Eastern U.S.

$$
\text { R. F. Meier }
$$

XXI

Geotherma1 studies, West Virginia

H. Heike

XXI I Geothermal studies, Saratoga Springs, N.Y. .... J. R. Young

XXIII Geothermal Studies, Western N.Y, ........... K. Hilfiker

XXIV Geothermal studies, Nebraska W. Gosnoid, Jr. 
XXV Geothermal studies, Delaware, and Comments Relating to Application at the Town of Lewes W. Woodruff

XXVI Geothermal Studies, Alabama

T. L. Nea thery

XXVII Geothermal Studies, Mississippi

E. Luper

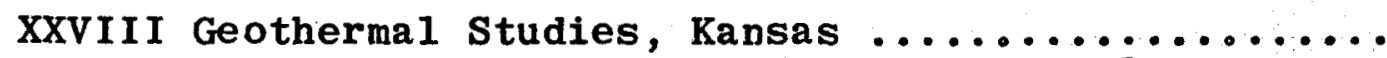

D. Steeples

XXIX U.S.G.S./WR Regional Aquifer Program ......... G. Bennett

XXX List of Attendees and Distribution and Meeting Agenda 


\title{
Summary of Department \\ of Energy - Geothermal Programs
}

\author{
by \\ Rudolph Black - DOE \\ Geothermal Resource Manager
}




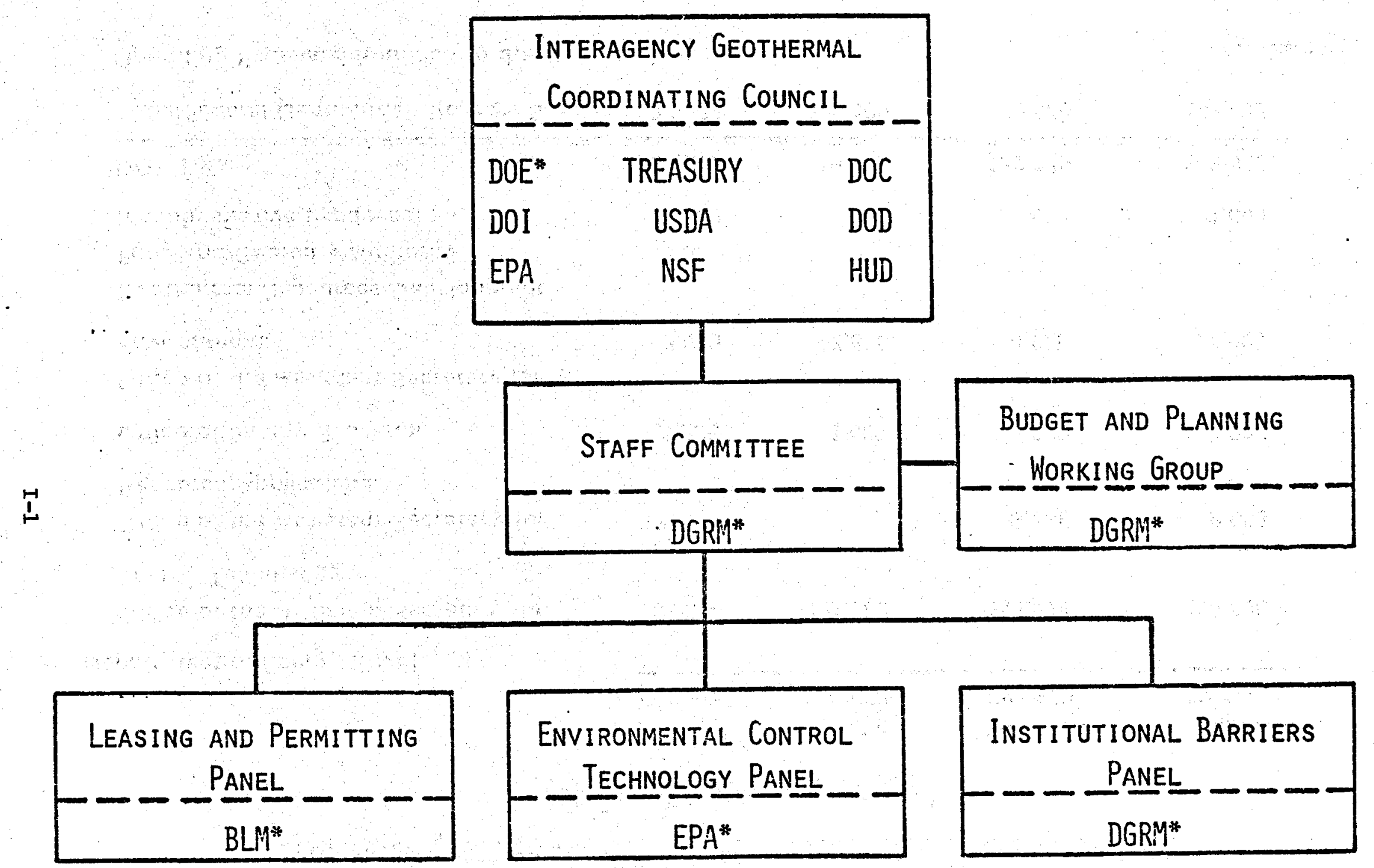




\section{Estimated Federal Funding for the Development of Geothermal Resources ( $\$$ in Thousands)*}

Department of Energy (DOE)

Office of the Assistant Secretary for Energy Technology

is Office of the Assistant Secretary for Resource Applications

Office of Energy Research

Office of the Assistant Secretary for Environment

Geothermal Resources Development Fund and Guaranty Authority

(Administrative Expenses)

DOE Total

Total Federal Geothermal Program Budget 74,508

"Operating Expenses Rounded to the Nearest Thousand

\begin{tabular}{rrrr}
$\begin{array}{c}\text { Actual } \\
\text { FY 1977 }\end{array}$ & $\begin{array}{c}\text { Actual } \\
\text { FY 1978 }\end{array}$ & $\begin{array}{c}\text { Estimated } \\
\text { FY 1979 }\end{array}$ & $\begin{array}{c}\text { Requested } \\
\text { FY 1980 }\end{array}$ \\
\hline 51,554 & 104,582 & 143,114 & 126,800 \\
& & 9,686 & 9,000 \\
1,235 & 1,400 & 1,920 & 2,225 \\
3,840 & 3,910 & 4,025 & 4,000 \\
& & & \\
380 & 410 & 1,000 & 1,000 \\
57,209 & 110.302 & 160.145 & 143,025 \\
\hline 74,508 & 129,100 & 180,940 & 161,495
\end{tabular}

GS7902555/9.45

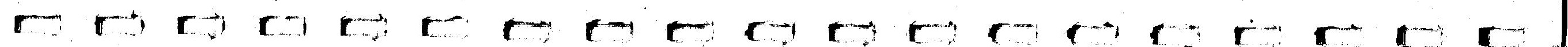




\begin{tabular}{|c|c|c|c|c|}
\hline $\begin{array}{r}\text { Estinated } \\
\text { Development } \\
\text { (\$ }\end{array}$ & $\begin{array}{l}\text { ara } \\
\text { Geotr } \\
\text { Hoods } \\
\text { Actual } \\
\text { FY } 1977\end{array}$ & $\begin{array}{l}\text { ding } \\
\text { mal } \\
\text { ds)* } \\
\text { Actual } \\
\text { FY } 1978\end{array}$ & $\begin{array}{l}\text { the } \\
\text { somerc }\end{array}$ & $\begin{array}{l}\text { Requested } \\
\text { FY } 1980\end{array}$ \\
\hline $\begin{array}{l}\text { Department of Agriculture (USDA) } \\
\text { U.S. Forest Service }\end{array}$ & 40 & 678 & 775 & 750 \\
\hline \multicolumn{5}{|l|}{ Department of the Interior (DOI) } \\
\hline Fish and Wildlife Service & 200 & 200 & 200 & 200 \\
\hline Bureau of Land Management & 2,500 & 2,300 & 2,600 & 2.600 \\
\hline Bureau of Mines & 528 & 550 & 650 & 650 \\
\hline Bureau of Reclamation & $1: 420$ & 1.080 & 1.250 & 900 \\
\hline Geological Survey & 11,831 & 13,828 & 15,375 & 13,400 \\
\hline $\begin{array}{l}\text { DOI Total } \\
\end{array}$ & 16.479 & 17,953 & 20,075 & 17,750 \\
\hline \multicolumn{5}{|l|}{ Environmental Protection Agency (EPA) } \\
\hline Office of Research and Development & 600 & 670 & 650 & 650 \\
\hline National Science Foundation (NSF) & 220 & 175 & 70 & 70 \\
\hline
\end{tabular}




\section{GEOTHERMAL RESOURCE MANAGEMENT AND SUPPORT}

\section{HYDROTHERMAL FUNCTIONAL ORGANIZATIONS}

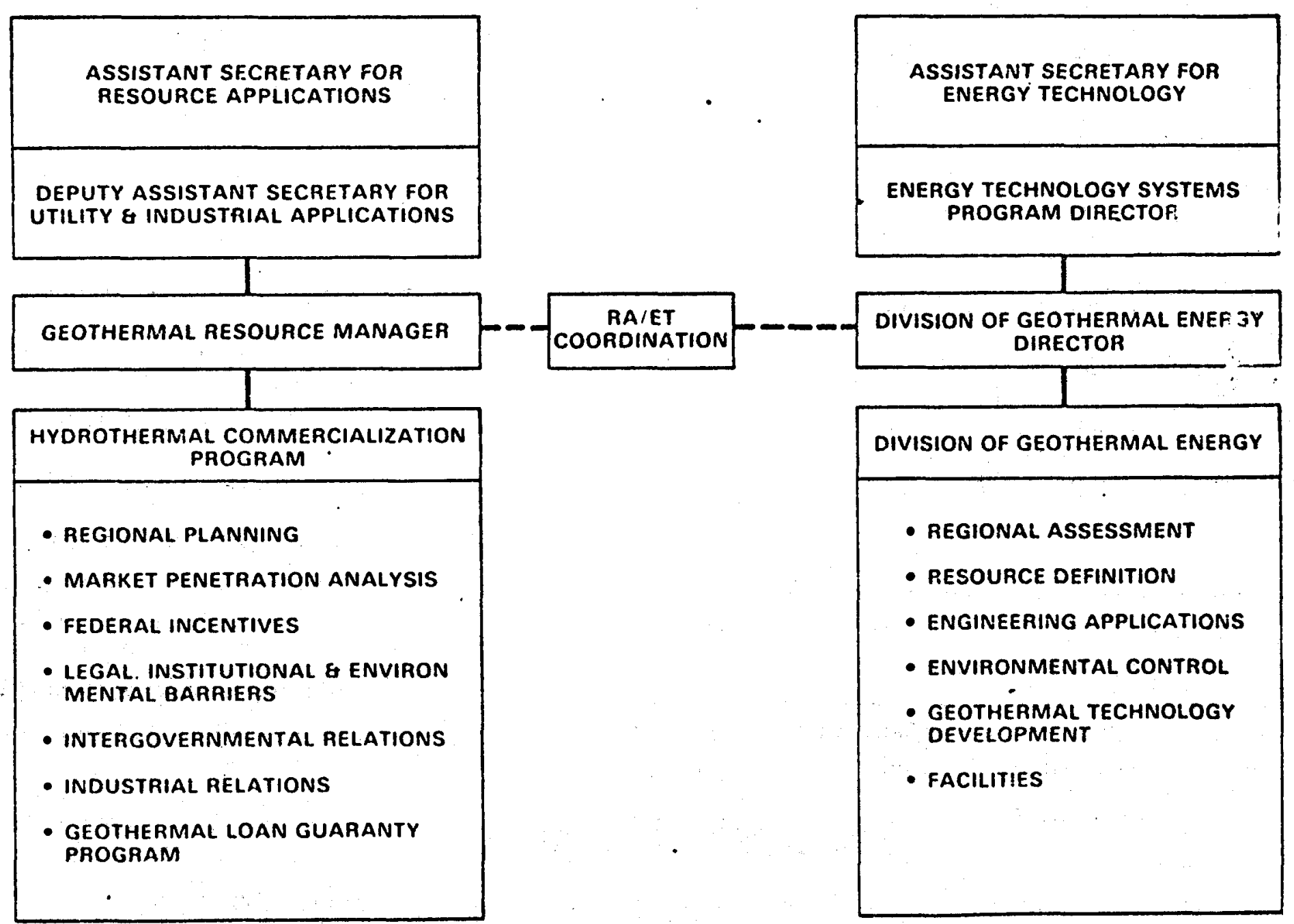


RA/GWO Coomommilly

\section{Funchonal Organcotion}

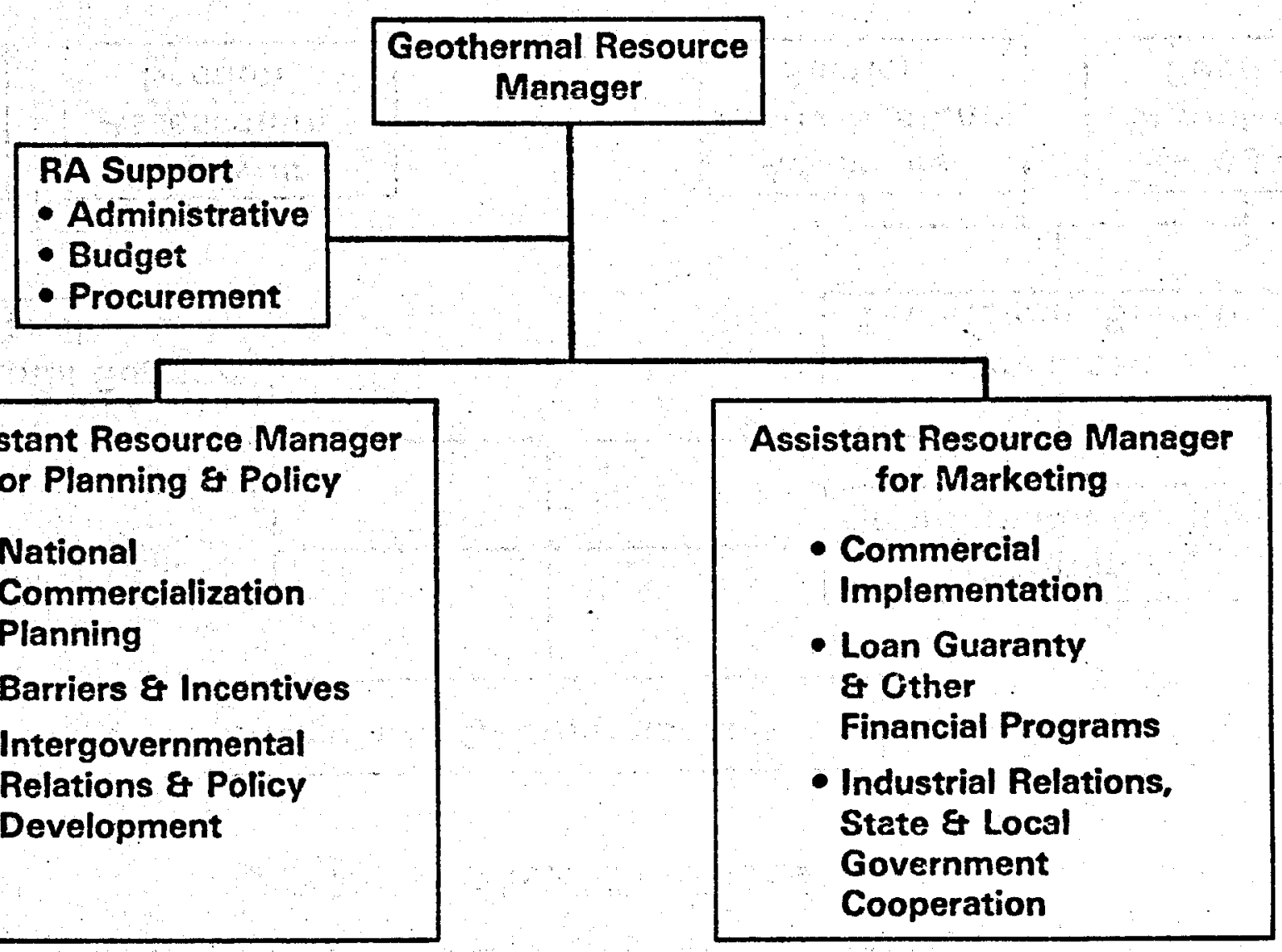




\section{Department of Energy Division of Geothermal Energy Organization Chart}

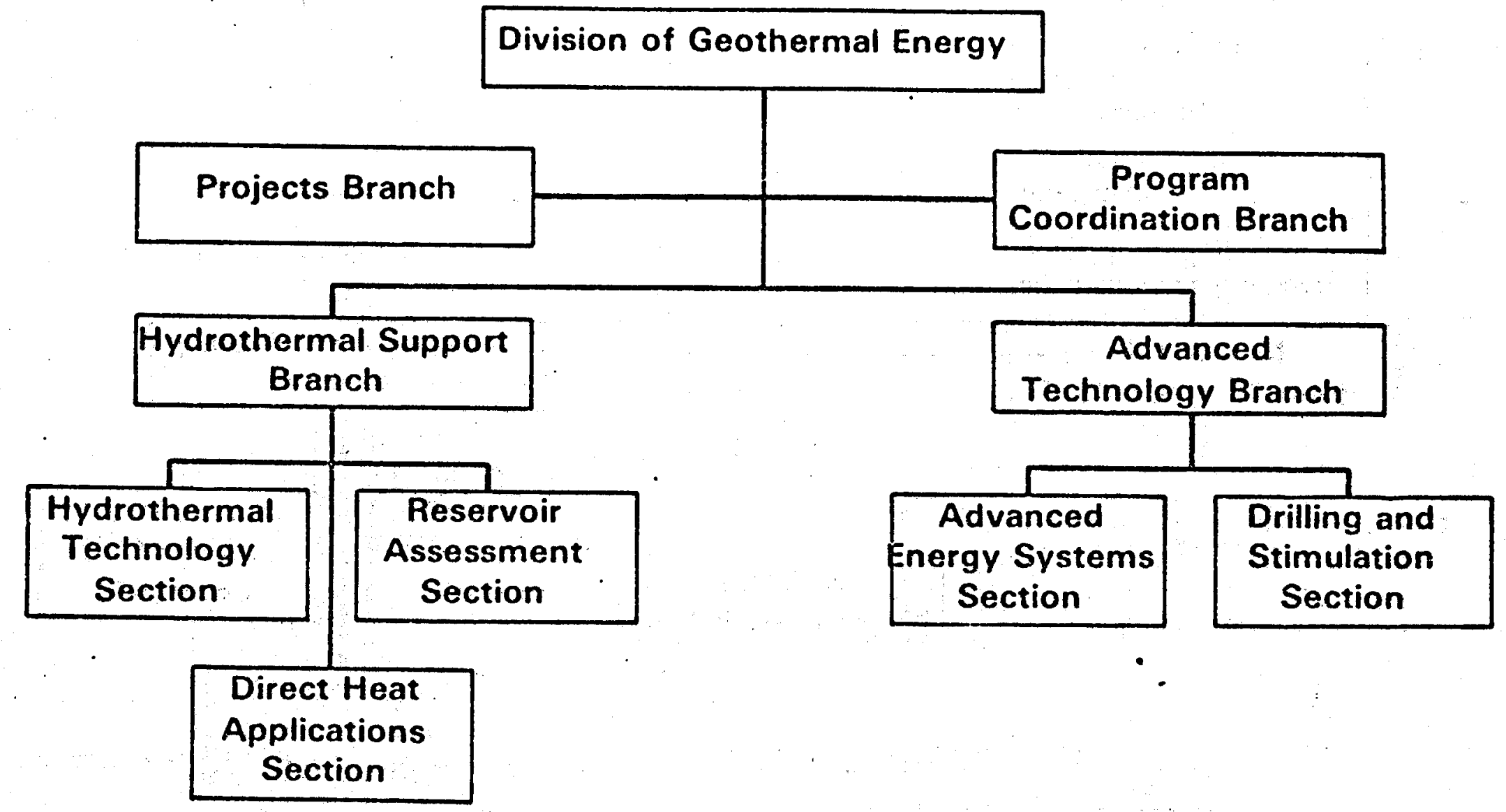




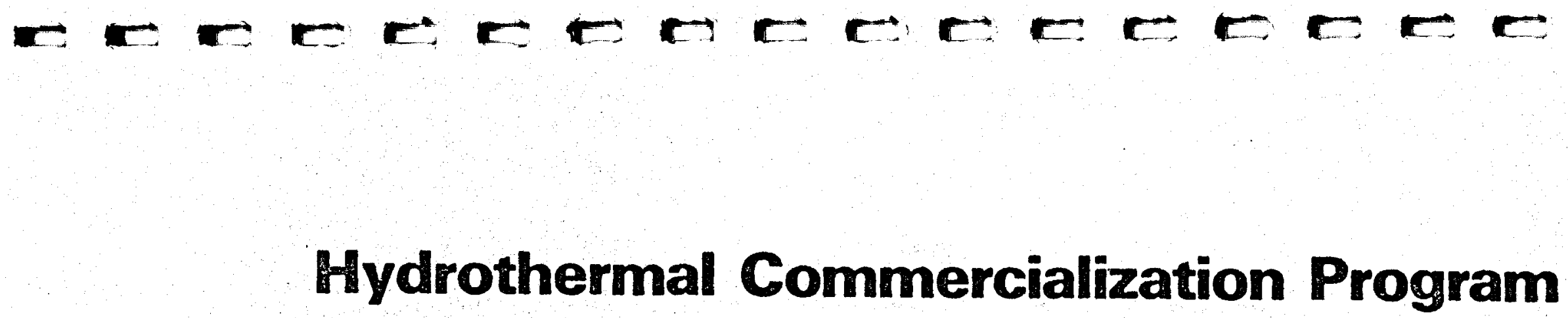

Goals for Hydrothermal Resource Utilization

$1985 \quad 2000$

Electric Power Applications

Electric Capacity (MW)

$3,000-4,000^{*} 20,000-40,000$

Fossil Fuel Displaced (q/yr)

$0.2 \cdot 0.3$

1.5-3.0

Direct Thermal Application (q/yr)

$\frac{0.1-0.2}{0.3-0.5} \frac{0.5-2.0}{2.0-5.0}$

Total Thermal Energy (q/yr)

$50-90$

$350-900$

*Includes The Geyers (Steam) Field 


\section{Geothermal Electric Capacisy Growth}

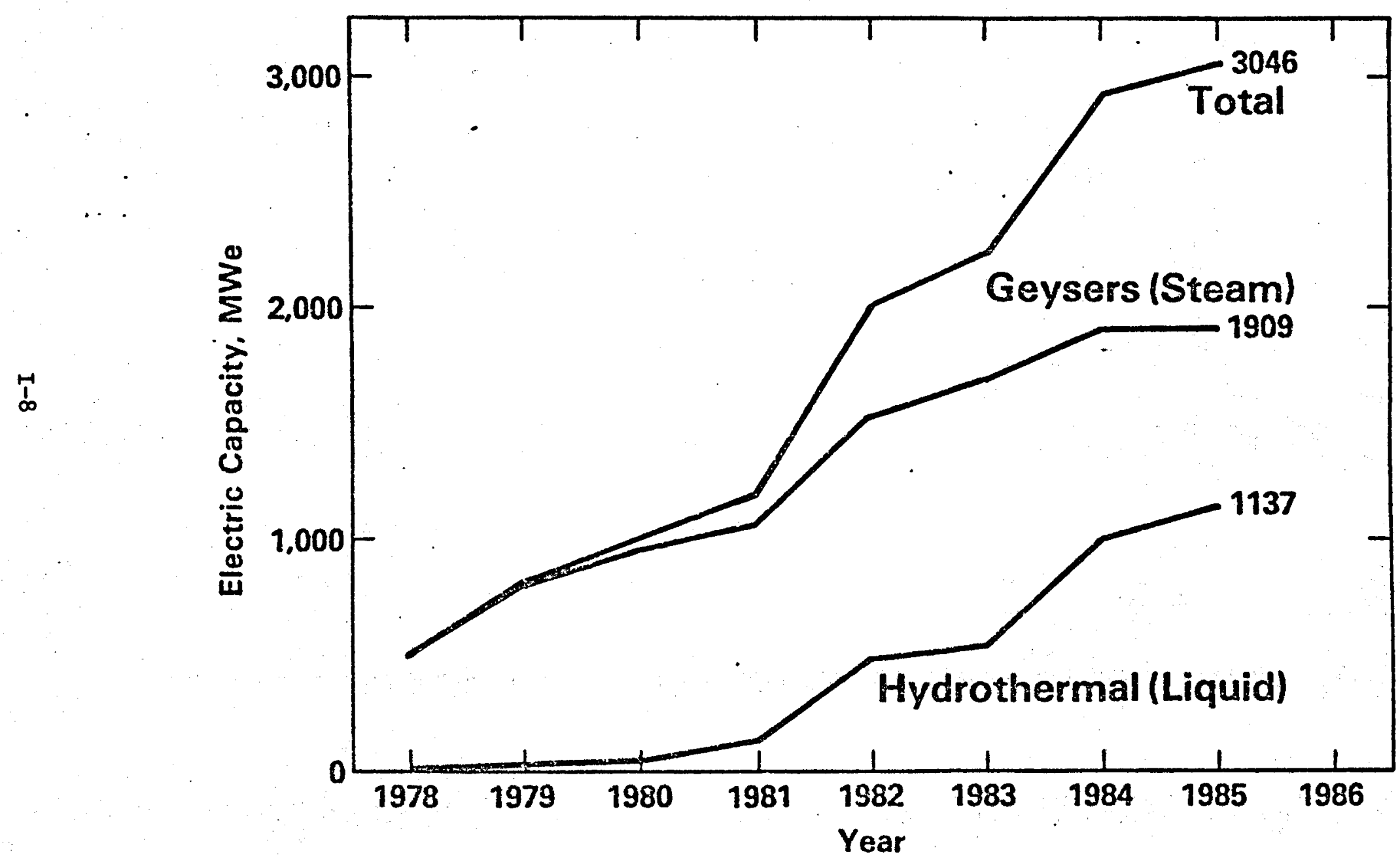

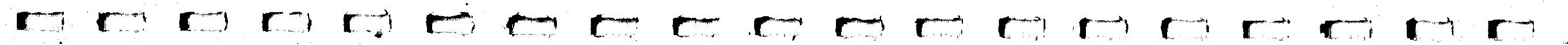




\section{Direct Heat Utilization Projections}

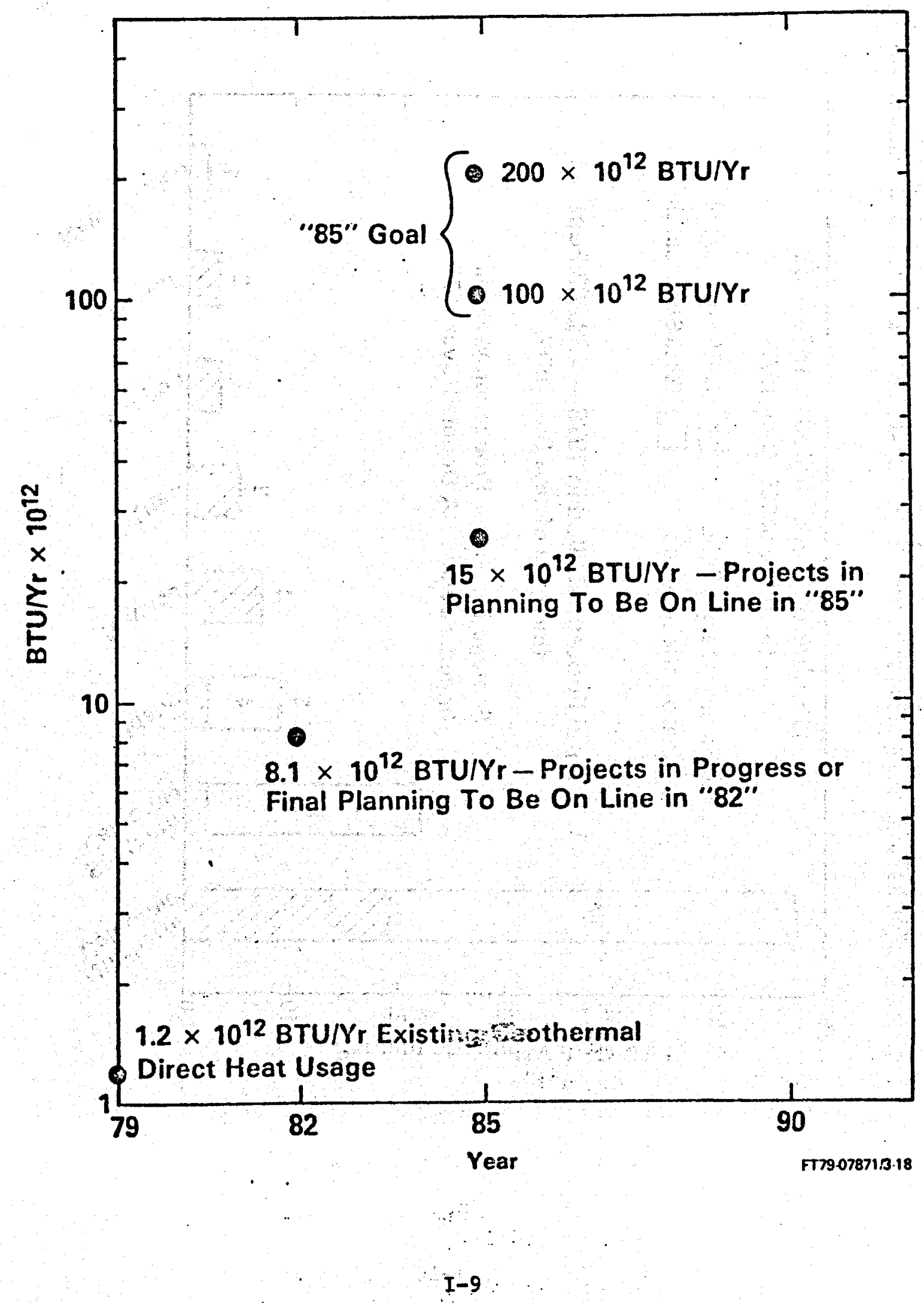




\section{Geothermal Drilling - Western United States}

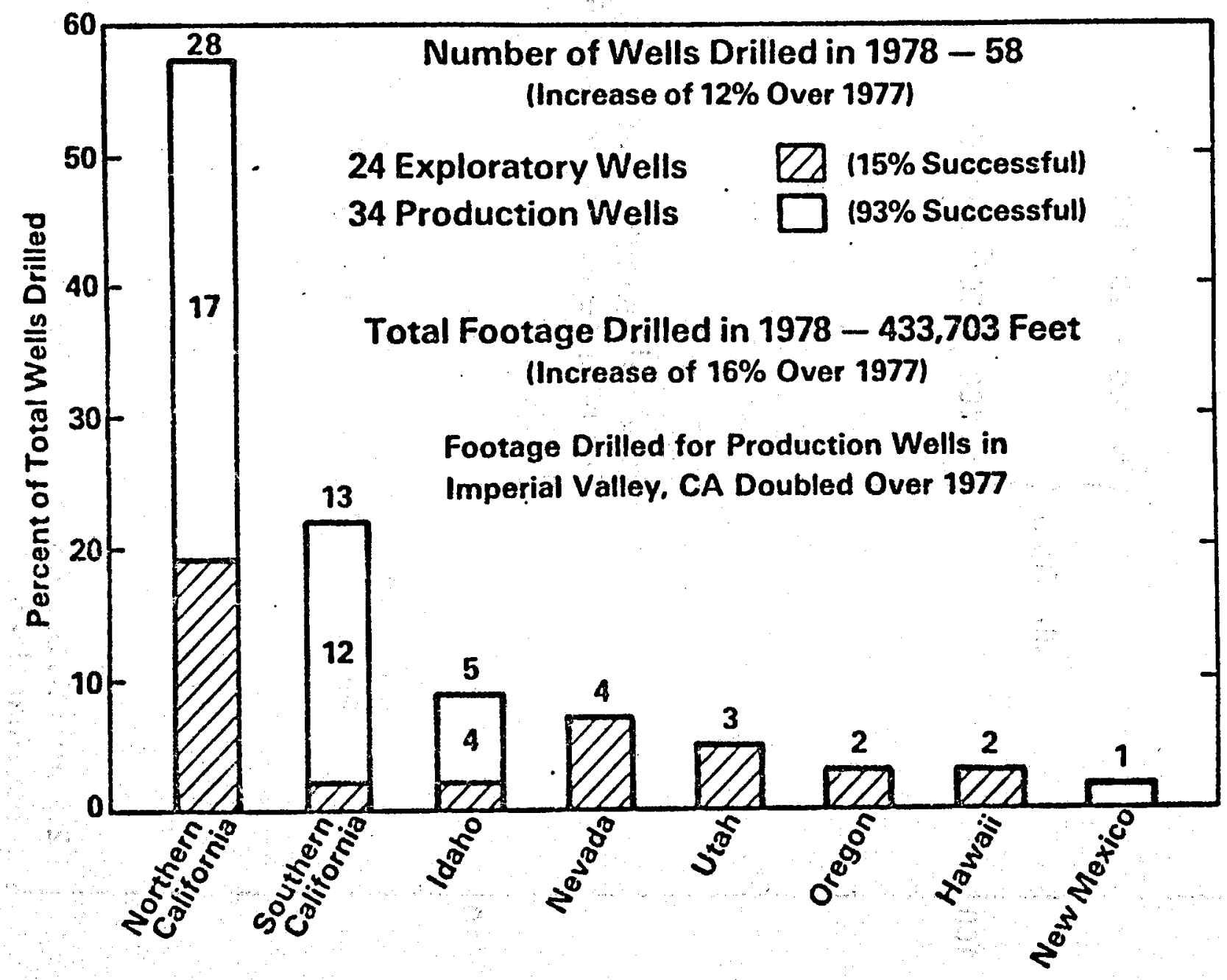

FT79078715.18 



\section{HYDROTHERMAL COMMERCIALIZATION PROGRAM}

PROGRAM DESCRIPTION:

STIMULATE PRIVATE SECTOR GEOTHERMAL DEVELOPMENT FOR

ELECTRIC POWER GENEAATION AND DIRECT HEAT APPLICATIONS BY:

- OUTAEACH

- MARKET ASSESSMENT

- RESOURCE DEVELOPMENT PLANNING

- BARRIER AND ECONOMIC ANALYSIS

- PROGRESS MONITORING

- APPLICATION PROJECTS

PROGRAM GOAL:

PROMOTE COMMERCIAL DEVELOPMENT AND UTILIZATION OF THE NATION'S LARGE GEOTHERMAL RESOURCES FOR ELECTRIC POWER PRODUCTION AND FON DIRECT HEAT APPLICATIONS.

MAJOR NEAR TERM OBJECTIVES:

- EXPAND RESOURCE DEVELOPMENT. ALREADY UNDERWAY FOR DRY STEAM. TO MUCH LARGER LIQUID-DOMINATED RESOURCE BASE

- ACCELERATE GROWTH OF GEOTHERMAL ELECTRIC POWER GENERATION CAPACITY BY ECONOMIC INCENTIVES AND REMOVAL OF INSTITUTIONAL BARRIERS

- STIMULATE DEVELOPMENT. NOW BAAELY BEGUN. OF LOW.TO. MODERATE TEMPEAATURE RESOURCES FOR DIRECT HEAT APPLICATIONS 


\section{Planning and Analysis \\ Interagency Coordination \& Federal Policy Development}

\section{Activities}

- Interagency Geothermal Coordinating Council (IGCC)

- Annual IGCC Report to President and Congress

- Geothermal Energy Omnibus Bill (GEO)

- State Workshops

- Regulatory, Legislative, Administrative Actions

\section{Accomplishments}

- Annual IGCC Report Published May 1979

- IGCC Geothermal Streamlining Task Force Report

- Draft Input to Proposed IGCC Geothermal Energy Omnibus Bill and Review of Church and McClure Bills

- Workshops Held in Six States (WA, NM, UT, VA, OR, DE) To Define Legislative Needs

- Joint Federal/State/Industry Planning Concept Developed for Environmental Assessment of Electric Site in Utah 


\section{Planning and Analysis Economic Evaluations and Barrier Analysis}

Activities

- Cost of Power Analysis

- Investment Decision Model

- Market Penetration Analyses

- Long and Short Term Supply Curves

- Net Energy Analyses

Barrier Identification and Mitigation

Accomplishments:

- Cost/Benefit Analysis - Impact of R\&D on Geothermal Development

- Supply Curves Developed for Known Plus Inferred Resources

- District Heating Cost Models Developed and Tested

- Barrier Mitigation Remedies Evaluated:

- Tax Policy

- Land Policy

- Environmental Policy

- Regulatory Activities 



\section{Private Sector Development Hydrothermal Applications}

Activities

- Engineering \& Economic Studies of Direct Heat Applications

- Direct Heat Applications and Hybrid Electric Projects

- Geothermal Loan Guaranty Program

\section{Accomplishments}

- Eleven Technical/Economic Analysis of Direct Heat Applications

- Applications Projects - "Cascades" Development (Oregon)

- "Honey Lake" Hybrid Electric (California)

- Westmoreland Loan Guaranty Application Approved Under GLGP

- Proposed GLGP Regulations Published 


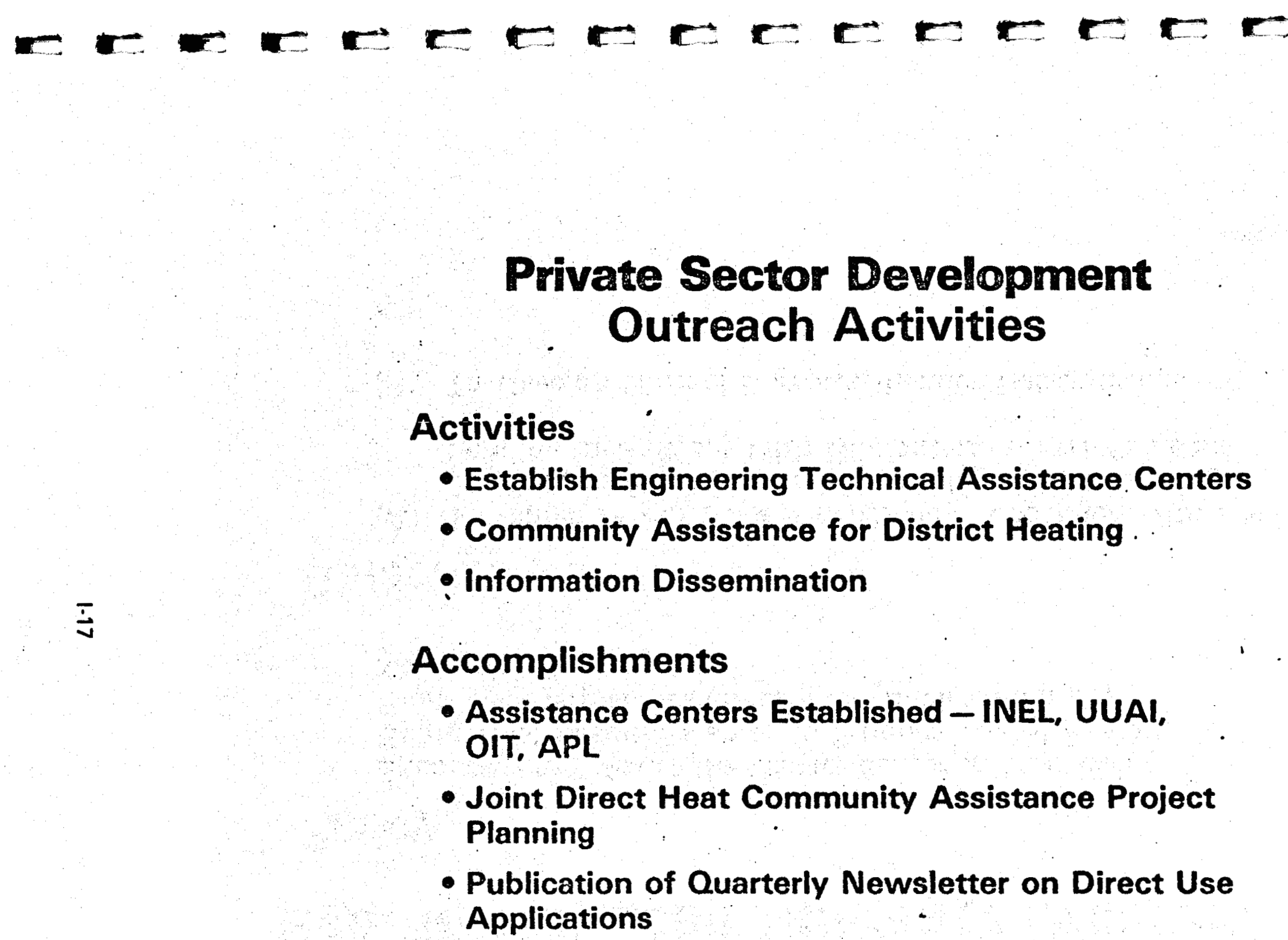

\section{Private Sector Development Outreach Activities}

Activities

- Establish Engineering Technical Assistance. Centers

- Community Assistance for District Heating

- Information Dissemination

Accomplishments

- Assistance Centers Established - INEL, UUAI, OT, APL Planning

Applications 


\section{Geothermal Loan Guaranty Program}

\section{Policy}

Encourage and Assist the Private Sector in Developing Geothermal Resources so as to Produce Useful Energy From Geothermal Resources in an Environmentally Acceptable Manner

\section{Objective}

(A) To Minimize Financial Risk Usually Associated With New Geothermal Resources and Technologies by Providing Lending Institutions With Guaranties on Private Loans

(B) To Develop Normal Borrower-Lender Relationships 



\section{Potential Loan Guaranty Applications Currently Being Prepared}

Application

1. Field Development and 25 MWe Power Plant

2. $55 \mathrm{MWe}$ Power Plant

3, Field Development

4. Cascading-Direct Use

5. Greenhouse

6. Field Development

7. 64 MWe Power Plant

8. Field Development
Location

Puna, Hawaii

Roosevelt Hot Springs, UT

Geysers, CA

Beryl, UT

Colorado

East Mesa, CA

East Mesa, CA

Brawley, CA

Total
Amount

\$ 44 Million

25 Million

15 Million

60 Million

3 Million

17 Million

67 Million

25 Million

\$256 Million (Estimated) 


\title{
Federal/State Geothermal Planning
} and Project Implementation

\author{
by \\ Burton Barnes - DOE - \\ Office of Geothermal Resource Manager
}


Good morning. Rudy has given you the broad perspective of the national geothermal program; now, I would like to take this opportunity to give you some of the philosophy as it applies to State and Local government planning and implementation of the program. In the course of this meeting, we of DOE would also be most interested in learning your reactions to this philosophy. In the Western United States, we see changes occuring that are due to both the Federal and State government's planning effort and an accelerating Interest by the public and private sectors in geothermal development. Similar reactions are beginning in the East. We have become quite sophistlcated since we began two years ago with the planning effort under what was then called a regional operations research program. We first Identified the resource potential and then produced site-specific development scenarlos; today we are conducting market assessments and penetration analysis. We realized early-on that a stateby-state approach to planning and Implementation was necessary. As a result, the private sector is moving ahead and we are now seeing development projects underway or being formulated in many parts of the U.S. Developers and end-users need the results of state planning and also technical and financial assistance to convert these plans into projects. In the West, we belleve a solid base has been established by the state planning teams and their interactive network and look forward now to establishing a similar network in the East. Once established, this can be used in the next step, which is project Implementation.

We would like to work with you in developing the organizational structure for planning and implementation. The planning effort, as you will soon learn, is a jointly-sponsored, cooperative effort, including the States, DOE, 
and may involve other Federal agencies; such as, the Title V Regional

Commission, Department of Housing and Urban Development, Urban Development

Actions Grants, Department of Commerce, Economic Development Administration, and the Department of Agriculture, Farmers Home Loan Administration.

Project implementation will

continue as a jointly-sponsored effort but will bring greater participation by seeking additional financial support from the Private Sector as well as other Federal, State, and Local government agencies. We believe that what we are doing will not only achieve DOE's objectives and those of other Federal agencies which are mandated to assist the development of alternate energy soures, Including geothermal resources, but will also satisfy the needs of the states in terms of gaining energy self-sufficiency. A combined effort requires commitments on the part of each participant, and it is in our mutual interest to work together.

We have grown considerably since the State and Local Government Planning Program began two years ago. There are now 15 western states involved in the planning effort, and we anticipate three additional states will be foining us from the eastern part of the U.S. during the coming year. Obviously, this growth will require greater commitments from DOE and from each participant, and we must consider carefully our financial resources. The planning for development must proceed in each of the states simultaneously with implementation. As each state establishes a planning capability, the Federal Government w11l shift its emphasis for fostering implementation of site-specific development projects. Based on the progress to date, we estimate the period required for establishing a state planning capability to be three years. Thereafter, the States themselves will be expected to take on the full fundingresponsibility for the planning part of the program, thus terminating DOE's participation in the State Planning Programs and shifting emphasis to assisting the states in development projects. 
Now, I would like to give you some Insight as to how we plan to develop

the implementation program. The first phase, the

assessment program is in place. It can be described as a 4-phase approach and is partially contained in legislative proposals now before the Congress, which,

if enacted, could have significant impact on geothermal development in the

U.S., particularly in the eastern U.S. (SLIDE): As you can see on the

slide, the Program is targeted at end-users and direct-heat applications

and is cost-shared. The First Phase involves Resource Assessment, mainly being

carried out through the State Cooperative Program in low-to-moderate temperature

resource assessment and by the private sector; the Second Phase consists

of the economic and engineering feasibility studies for site-specific and

applications-specific projects; the DOE Program Research and Development

Announcements, or so-called "PRDAs," currently represent this phase, a

subject which Morris Skalka w1ll cover in some detall this morning. The

Second and Third Phases are presently embodied in Congressional inftiatives

now before the Congress-a subject which Randy Stephens will describe

In detail to you tomorrow and which I will only briefly touch on now.

Senator McClure has introduced a B1ll (S. 1330) comparable to the Phase II .

element consisting of a cost-shared "forglvable" loan program-the intention $\therefore$

being that if a project was determined to be technically or economically

unfeastble, the repayment of the protion covered by a Government loan would

be cancelled, However, assuming success in the Phase II effort, the Third

Phase, as proposed by Senator Church (S. 1388), would provide funding for

drilling and reservolr confirmation. Under this phase, a few deep exploratory

tests could be completed and flow-tested at each project site. This would

prove or disprove whether a reservoir could provide energy sufficient to

meet the requirements of the application for which it is intended. Currently,

DOE Is funding exploration drilling and reservoir confirmation under the

Direct-Heat Program Opportunity Notlces and under the Geothermal Loan Guaranty

Program. Senator Church's B111 (S. 1388), proposes Phase III as

another cost-shared "forglvable" loan program; that 1s, like the Phase II

II -3 
feasibility studies, if the reservolr does not prove to be comercially producible, the portion of the loan given by the Government would be cancelled. Given success in both Phase II and III, the user would have the alternative of designing and constructing a facility using either the Phase IV Geothermal Loan Guaranty Program, Issue revenue bonds, other Federal sources; such as, HUD/UDAG, EDA, FHA, Title V Commission funding, or seek private financing. No further authority would be required of Congress for the Phase IV Program except to increase the resource fund. Obviously, enactment of the Phases II and III by Congress will greatly enhance the magnitude and extent of project development. However, even without enactment, we belleve we can still Initlate the four-phase concept beginning in FY 1981, although at a much reduced level of effort. (REMOVE SLIDE)

The question Is not "whether" we do it, but "how" do we do it. We need to take maximum advantage of our state planning and state assessment programs as we enter the project implementation program. We are already recelving proposals and inquiries from communities, as well as from companies in the private sector. Working within the framework of our existing systems seems the most plausible way to proceed in view of our limited resources.

With regard to resources, I want to propose ways in which we can stretch our very limited budgets and, at the same time, enhance our capability.

The first mechanism is to develop a data base on the resource potential and assess the market potential. In doing this, we fhald take maximum advantage of resources now in place; such as, the New Mexico Energy Institute, BNL, and APL, and state resource data.

A second mechanism for stretching our resources while enhancing our capabilities is in the outreach program, which will more thoroughly than before deliberately develop and alsseminate information on geothermal 
energy to a range of specific target groups. We need to integrate at the national level the output of each of the respective state outreach programs as these take place to maximize the benefits. Each outreach effort and program should benefit not only a single state and reglon, but each has the potential for providing real information on geothermal to the region and the nation as well. In order to assist the states in this effort, we have contracted with International Business Services and their representative, Mr. John Engle, Is with us today. I hope you will take this opportunity to meet Mr. Engle and learn about IBS involvement in the outreach program.

A third mechanism for building on our resources is to coordinate the State Planning and Resource Assessment Programs with the programs being carried out by other Federal agencles whose objectives complement our own. In - Washington, our Program Managers have already met and begun negotiating with several of these agencies to promote interest in the Geothermal Program. For example, Eric Peterson and Dick Gerson, who are here today, are serving on a District Heating Task Force headed by the Department of Housing and Urban Development. HUD is in the process of Implementing, through Its Urban Development Action Grants Program, a program to provide funding to communities for public works projects, which will include district heating projects using geothermal energy. We are discovering that there are many communities that qualify for HUD assistance, which are colocated with geothermal resources. Other Federal agency actions aimed at rural development Include the Farmers Home Loan Administration. This agency has recently Indicated a willingness to put up $\$ 2 M$ over the next two years in matching funds for development projects Involving utilization of geothermal resources. 
I have mentioned a few mechanisms, all of which depend on teamwork and your participation.

In conclusion, I hope that I have conveyed to you the Importance we place on your individual planning and resource assessment efforts. We believe that a joint Federal/State Planning and Project Implementation Program is a natural follow-on necessary to encourage and accelerate geothermal resource development. In this respect, we see this as a team effort in which your contributions mean more than merely satisfying a DOE contract, grant, or cooperative agreement; for your efforts not only benefit the nation but your respective states as well.

I look forward at this meeting to hearing of your progress and receiving Individual comments on the program presented this morning. Thank you.

Attachment 
USER-COUPLED, COST-SHARED DEVELOPMENT PROJECTS

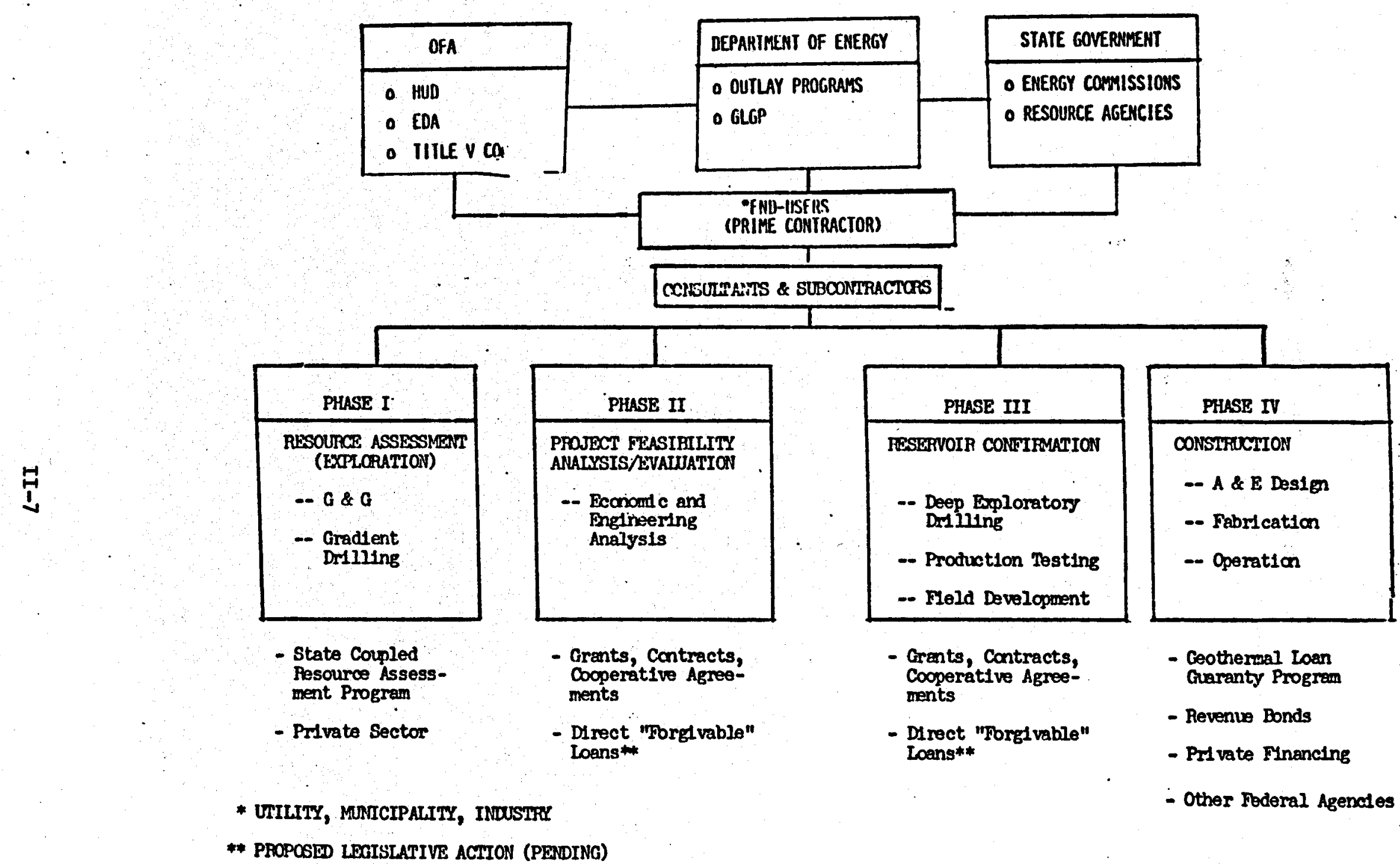

* proposed legislative action (PEnding) 
Summary Description of the

\section{DOE/DGE State Coupled}

Program

by

Dr. Gerald D. Brophy - DOE Division of Geothermal Energy 


\section{Summary Description of the State Coupled Program}

The objectives of the State Coupled Program are 1) to assist the U.S. Geological Survey in extending the inventory of geothermal resources in the United states to Include the low temperature $\left( \pm 20^{\circ} \mathrm{C}<\mathrm{T}<90^{\circ} \mathrm{C}\right)$ reservotrs most suitable for direct heat application, 2) to publish maps and reports on low- and moderate-temperature geothermal resources, and 3) to stimulate reservolr confirmation studies at sites where the private sector has no present interest in development but which have an apparent but unquantified potential for direct heat application development.

The State Coupled Program is carried out separately but concurrently in participating states by interdisclplinary groups from Federal and State agencies and other organizations. Each project is carried out in two phases, which may or may not operate concurrent1y:

PHASE I: 1. Compilation of avallable data and collection of new data on temperature, thermal gradient, water quality, aquifer productivity, and other related geologic Information;

2. Submission of certain 1tems of the bastc data from (1) above for Inclusion In USGS computer file GEOTHERM;

3. Publication of geothermal maps and reports based on interpretation of these data. 
PHASE II: 1. Selection, by use of the Phase I data base and the following criteria of specific sites for detailed surveying;

a. Geological investigations of the above specific sites to select drill-test locations;

b. Drill testing for thermal gradient determination and for reservolr confirmation and assessment;

c. Publication of site-specific results, including distribution of maps and reports to potential developers of direct-heat geothermal resources. Background

Most geologists agree that there are many more low- and moderate-temperature $\left(20^{\circ} \mathrm{C}\right.$ to $\left.150^{\circ} \mathrm{C}\right)$ hydrothermal resources than there are high-temperature hydrothermal resources. U.S. Geological Survey Circular 790 documents the distribution of hydrothermal resources as a function of temperature down to $90^{\circ} \mathrm{C}$, with the conclusion that there is an exponential increase in the number of known occurrences as temperature of the resource decreases. This means that the geographic distribution of hydrothermal resources is wider and that the possibility of co-location with a user is Increased as temperature decreases. Considering this relationship, it is possible that direct heat utilization of low- to moderatetemperature geothermal resources will ultimately contribute more power on line than will electrical generation from high-temperature geothermal resources simply because lower temperature resources are so much more plentiful and widespread. 
There is very little use presently being made of lowand moderate-temperature hydrothermal resources. The maln reasons for this appear to be 1) lack of enough knowledge of the resource itself to attract users, and 2) the present high risk level and high costs associated with reservoir confirmation drilling. By contrast, direct utilization of a geothermal resource, once it Is discovered and confirmed, usually consists of reasonably straightforward engineering.?

A new ambitious program known as the User Coupled Direct Heat Reservoir Confirmation Drilling Program is being planned by DOE to start in fiscal year 1981. This program will be a vital ingredient for the development of hydrothermal direct heat utilization in the United States. Development is presently hampered by lack of resource knowledge and the high costs and risks of reservolr confirmation, as mentioned before. In addition, there is presently no experienced infrastructure of consultants, contractors, engineers, equipment manufacturers and financial institutions in the private sector for direct heat development of the magnitude indicated as possible by the predicted large stze and widespread occurrence of the resource.

\footnotetext{
'Low-temperature geothermal resources generally have low salinities. Special high-temperature equipment and special techniques to handle high salinities are problems usually encountered only with hightemperature resources. Most direct heat geothermal applications can use off-the-shelf equipment and techniques.
} 
The present high risk level for reservoir confirmation stems partly from the lack of resource knowledge and partly from the fact that present surface surveying techniques are not well enough developed to ensure with a high level of probability that a dri11 hole w111 intercept a resource. Hydrothermal reservoirs are never uniform or continuous, so that dry holes can be drilled in the middle of the best of these resources. Better techniques for, and more experience in, siting well are needed to decrease the risk of drilling an unproductive well. The high costs of reservolr confirmation result mainly from the high cost of driliing.

Present developers of electrical power generation from high-temperature reservolrs are generally large companies that can finance reservoir confirmation by spreading the high risk and cost over many projects. These large companies are usually not interested in development or utilization of lower temperature reservolrs because of the relatively small scale of such projects. Small developers, the ones most likely to be interested In low- and moderate-temperature hydrothermal resources, are unable to spread risk and cost in the same way that a large company can, and a single unproductive well can mean financial disaster for them.

For the above reasons, it is not expected that the direct heat user in the private sector will be able to perform needed reservoir confirmation for low- and moderate-temperature hydrothermal resources alone in the near future. Without federal assistance these will continue to be very little use of the large lower temperature hydrothermal resource base that exists in the United States. 
The User Coupled Drililng Program would consist of DOE cost-shared surface exploration and drill confirmation of hydrothermal reservoirs. Users and developers in the private sector would share costs with DOE and would perform the work. DOE's cost share would be low for a successful project (a project that intercepts a hydrothermal resource having previously determined temperature and production characteristics) but would be high for an unsuccessful project. Development of the hydrothermal resource, once confirmed, would proceed by private investment, perhaps atded by PON or Geothermal Loan Guarantee funds.

This program would result in development of an estimated 25 percent of the total infrastructure that wi11 be needed In order for private users to develop about 1.5 Quads of direct heat uses by the year 2000, an amount we11 within the DOE stated goal of $0.5-2.0$. The remaining 75 percent of Infrastructure development would come from users once the total economic picture of direct heat use is developed as a result of the new program. As a result of this new program, about 0.15 Quads of direct heat utilization would be developed by 1982 , in IIne with DOE's near-term goals.

Regional exploration and resource data generated by the State Coupled Program are important for the success of the new User Coupled Drilling Program, as these data provide the basis for good site selection. Timely generation of data by the state Coupled Resource Assessment teams is required, so these data may be used by proposers to the Reservoir Confirmation Program. 
One of the most important interfaces between federal geothermal programs is between the State Coupled Resource Assessment Program and the state Commercialization Planning Program. The latter is a program which has the objective of planning for geothermal development within each state. The resource data base used for this planning is developed by the State Coupled Program resource assessment teams. Cooperation and mutual support are specific goals of both programs.

The Industry Coupled Program of DOE/DGE is a costsharing program with industry which has the objective of increasing the amount of exploration and reservolr assessment that industry is able to do for high-temperature resources suitable for electric power generation. In the process of carrying out this program, data on low- and moderate-temperature resources are automatically generated at specific sites. This program is currently active at only about 15 sites which have specific high-temperature potential, whereas regional geothermal data compliation and low- and moderatetemperature reservoir confirmation are needed at many more sites which have no current interest to the large developer.

By congressional mandate, the U.S. Geologlcal Survey has lead responsibility for federal geothermal resource assessment and inventories. The state coupled Program aids the USGS In this task by providing data on hydrothermal resources to the USGS for inclusion in computer file GEOTHERM and for inventory and other uses. An agreement of cooperation exists between DOE and the USGS to facilitate this interface. 
Participants in the State Coupled Program have several responsibilities for cooperation with the USGS as follows:

1. Periodic (at least quarterly) update of file GEOTHERM data for the state;

2. Working with USGS resource assessment personnel during their periodic inventory updates.

3. Working with the local Water Resources Division personnel, who can and will furnish temperature and hydrologic data on wells and springs.

Lack of resource knowledge occurs on two levels of

detail:

1. On a regional scale, the locations of low- and moderate-temperature resources are poorly known; Phase I of the State Coupled Program has the objective of correcting this deficiency;

2. On a site-specific scale, the lateral limits, depth, temperature, productivity, and longevity of very few 1 ow- and moderate-temperature geothermal reservolrs are known. Very little surface exploration and drilling have been done. A new Planned User Coupled Direct Heat Reservoir Confirmation Drilling Program has the objective of correcting this deficiency. Phase II of the State Coupled Program will assist in this by making detailed studies of a few selected sites. 
List of States in which DOE/DGE has Low to Moderate Temperature Resource Assessment Programs

State

Contractor

Cooperative Agreement

Alabama

Alaska

Arizona

Arkans as

California

Colorado

Delaware

Georgia

Hawaii

Idaho

I11inois

Iowa

Kansas

Maryland

Massachusetts

Michigan

Missouri

Montana

Nebraska

Nevada

Nèw Jersey

New Mexico
Alabama Geological Survery

Alaska Geological Survey

U. Alaska - Institute of

Geophysics

Bureau of Mines and Geology

LASL

Bureau of Mines and Geology

$0 i 1$ and Gas Commission

Colorado Geological Survey

Delaware Geological Survey

VPI

U. Hawaii - Institute of Geophysics

Department of Water Resources

Gruy Federal

Gruy Federal

Ransas Geological Survey

VPI

Gruy Federal \& Dunn Geoscience

Gruy Federal

Gruy Federal

Montana Bureau of Mines

Nebraska Geological Survey

Nevada Bureau of Mines \& Geology

VPI

New Mexico Energy Institute 
State

New York

North Carolina

North Dakota

Ohio

Oklahoma

Oregon

South Carolina

South Dakota

Texas

Utah

Vermont

Virginia

Washingt on

West Virginia

Wyoming
Contractor

NYSERDA (Dunn Geoscience)

VPI

N.D. Geological Survey

LASL to be followed by -

Geological Survey

Startup FY 1980

Oregon Geological Survey

VP.I

Program to be started FY 1980

S.D. Geological Survey

Bureau of Economic Geology

Texas Energy Advisory Council

Bureau of Mines \& Geology

Gruy Federal \& Dunn Geoscience

VPI

Department of Natural Resources

VPI - Completed

U. Wyoming
Cooperative Agreement 
Future Directions in the Direct

\section{Heat Applications Program}

by

Morris Skalka - DOE -

Division of Geothermal Energy 


\section{Future Directions in the Direct Heat Applications Program}

The main impediments to commercial'development of geothermal energy resources for direct applications are (1) lack of knowledge of the resources at particular sites, (2) the high risk for small developers and (3) the high cost to confirm the resources.

For these reasons, the future direction for the direct heat applications program, as in the past, will be to assist in defining the resource, while at the same time helping to reduce the risk for interested developers by helping to finance future developments.

For FY 1980 our current plan is to continue the 22 application projects with funds available in the FY 1980 budget. We will also issue a solicitation (PRDA) for cost-sharing engineering and economic studies directed toward industrial processing. Together with a state-coupled assistance program for development projects approximately $\$ 2$ million will be avallable in FY 1980.

To date, several western states have actively participated In geothermal development:

California has established a geothermal development authority. New Mexico has jointly funded several geothermal projects, while Idaho, Utah and Oregon are all contributing to our Direct Heat Application projects in these states. Similar efforts from additional states would be desirable. 
Wells Available for Project

Diamond King Ranch, S.D. ..

KF YMCA; OR

(4)

Pagosa Springs, Co

Navarro College, TX

\section{Resource Well Defined}

St. Mary"s Hospital, S.D,

Haakon School, S.D.

MERDI/Butte, MO

-Bolse, ID

Klamath Falls, OR

Kelly Hot Springs (GPC), CA

Susanville, CA

El Centro, CA

Holly Sugar - Brawley, CA

Monroe City, UT

Utah Energy Office/State Prison, UT

Memorial Hospital - Marlin, TX

Aquafarms, CA

Elko, NV

Moana - Reno, NV

\section{Resource Less Well Defined}

Madison County, ID

Ore-Ida Ontario, OR

Utah Roses, DT 


\section{Status of Federal Legislation}

of Interest to Geothermal Energy Development

by

Randall Stephens 


\section{GEOTHERMAL OMN IBUS LEGISLATION}

The Geothermal Energy Omnibus Legislation proposals that the Interagency Geothermal Coordinating Council was developing eariler this year have now been separated by the Congress into three separate bills. Not all the recommendations of the Council's Institutional Barrier panel were approved by the Administration, but essentially all of them are included in the bills, with some major added measures as we11.

The legislative process began with the introduction of two major bills, the Church and McClure bills and their counterparts in the House of Representatives, introduced by Congressman Santini and Symms. These are shown on the first chart. A third set of initiatives was proposed by Senator Packwood and others, and these tax credits have been incorporated in the Windfall profits Tax Bill s3919.

These two omnibus bills have been separated into their non-leasing and leasing provisions, which are being dealth with separately, so we now have the tax credit proposals, the geothermal title of the synthetic fuels bill, with the nonleasing provisions, and a leasing bill.

The tax credits have been approved by the Senate Finance Committee, and now await action by the senate. There are no similar tax credits in the House bill, so the major question will be acceptance of these expanded credits by the House conferees. The bill increases the credits in the National Energy Act to $50 \%$ for residential applications and to $20 \%$ for business applications, extends the time period to 1989 , and has some additional features shown on the chart.

Most of the non-leasing provisions of both the Church and McClure bills have been approved by the Senate Energy Committee as amendments to the Synfuels Bill, S932. That bill also has a House counterpart without similar provisions and depends on a Conference Committee acceptance, following full Senate action. It provides several major new programs, including a $\$ 750$ million forgivable loan program for geothermal reservoir confirmation driling, a $\$ 100$ milition reserve for reservoir insurance, and a \$50 million program of loans for non-electric feasibility studies and construction. The major elements of that title are shown on this chart.

The leasing provisions will be dealt with in a separate bill. Both the House and Senate committee staffs are working to develop compromise positions between the Church and Mcclure bills, and 
some action is expected in the next month or two. The major thrust of the leasing portion of the Omnibus Bill is to streamline federal leasing and permitting and to remove limitations and barriers to development on federal lands.

We expect to see further action on all three bills soon, and the prospects are very good that all three will be enacted by early next year.

R. C. Stephens 
PENDING

GEOTHERMAL ENERGY LEGISLATION

o GEOTHERMAL ENERGY OMNIBUS BILLS S. 1330/H.R. 4471,

S. $1388 / H, R, 5187$

- ACREAGE LIMIT INCREASE H.R. 740

- TAX CREDITS S. 3919 


\section{ALIERNATIVE ENERGY TAX CREDITS}

STATUS

SENATE FINANCE COMMITTEE APPROVED OCTOBER 18, 1979

PESIDENTIAL CREDIT

INCREASED TO 50\%

AVAILABLE TO BUILDERS

HEAT PUMPS INCLUDED (15\% UP TO \$2000)

EXTENDED TO 1990

WELLS SPECIFICALLY ELIGIBLE

BUSINESS CREDII

INCREASED TO 20\%

UTILITIES ELIGIBLE

EXTENDED TO 1990

REFUNDABLE

HEAT PUMPS ELIGIBLE FOR 10\% CREDIT

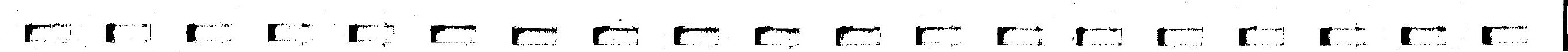




\section{SYNFIELS LEGISLATION (S, 932)} GEOTHERMAL PROVISIONS

- RESERVOIR CONFIRMATION LOANS ( $\$ 750$ MILLION) 90\% NONELECTRIC, $50 \%$ ELECTRIC

- RESERVOIR INSURANCE ( $\$ 100$ MILLION)

- DIRECT LOW-INTEREST LOANS FOR NONELECTRIC FEASIBILITY STUDIES, LICENSE APPLICATIONS, AND SYSTEM CONSTRUCTION (\$50 MILLION)

- 90\% LOAN GUARANTEES FOR MUNICIPALS AND COOPERATIVES

- LOAN GUARANTY PROGRAM EXTENDED TO 1989

- USE OF GLGP BY REA, HUD, SBA, FMHA AUTHORIZED (\$50 MILLION)

- EXPEDITED LOAN GUARANTY PROCESSING

- FEDERAL BUILDINGS PROGRAM

- EXPEDITED GEOPRESSURED, HOT DRY ROCK, AND ENVITRONMENTAL CONTROL TECHNOLOGY PROGRAMS

- PUBLIC UTILITY REGULATORY EXEMPTION EXPANDED TO 80 MWE

STATUS

SENATE ENERGY COMMITTEE APPROVED OCTOBER 24,1979 


\section{AMENDMENTS TO GEOTHERMAL STEAM ACI}

H.R. 740 - PASSED HOUSE SEPTEMBER 10, 1979, INCREASED ACREAGE LIMIT TO 51,200

SENATE ACTION EXPECTED ON:

- NARROW KGRA CRITERIA (SUBSTANTIAL GEOLOGICAL INDICATIONS OF ELECTRIC POTENTIAL, OR DEMONSTRATED COMPETITIVE INTEREST)

- CONDITIONED LEASING OPTION

- PROCFSSING TIME GOALS FOR LEASES AND PERMITS

- FEDERAL USE AUTHORIZED

- EXEMPT DEVELOPED ACREAGE FROM LIMITS

- FREE USE FOR SMALL-SCALE NONELECTRIC APPLICATIONS

- RELIEF FROM 10-YEAR READJUSTMENT AUTHORITY 


\section{Preliminary Definition of \\ Selected Geothermal Resources, Eastern USA}

by

Joel L. Renner

Gruy Federal, Inc.

Arlington, $\mathrm{Va}$. 
This is a general overview of the geology and potential for hydrothermal resources in the eastern half of the United States. Several other speakers w111 provide more detall concerning areas of particular interest within this region such as the Atlantic Coastal Plain and Hot Dry Rock targeting.

Slide 1 (FIgure 2)

The eastern region can be divided into the six regions shown on the slide on the basts of geology and geothermal potential. This partitioning is not unique because geologic areas generally do not have sharp boundarles.

The major structural features of the central stable region are gentle arches and domes and shallow basins (Figure 4). Faulting does not appear to have been Important in the formation of most structures. Although minor faults are associated with many of them. The most important zone of faulting is the 38th parallel lineament.

The Quachita region comprises two principal belts of deformation. Wichita and Quachita system and deep dedimentary basins associated with them (Figure 4).

The Gulf Coastal Plain is underlain by a thick wedge of sediments separated in many places from the interior regions by normal fault zone such as the Balcones, and Luling-Mexia-Talco (FIgure 4).

In the broadest sense the Appalachlan regton comprises a11 that part of the eastern U.S. where rocks were significantly deformed during Paleozolc time. The structural trend generally parallels the coastline. The region is divided Into the southern (Alabama to Charlottsville, VA) central (Charlottsville through Pennsylvania), and northern (New York to Canada) sections. Also four structural zones (Figure 2 ).

Strata in the Appalachian basin are nearly horizontal and maturely dissected. The basin represents a broad transition from the flat-1ying rocks, gentle arches and domes of the stable interior to the intensely folded strata of the 


\section{GRUY FEDERAL, INC.}

folded Appalachians.

In the folded Appalachlans the Paleozolc rocks are highly deformed to yleld step-limbed anticlines and synclines. In the central portion the deformation is belleved to be chiefly due to folding. In the southern sections thrust faults are the dominant causative agent. However, recent work suggests deep lying thrust faults control the structure in the central section as well.

The rocks in the Blue Ridge are predominantly metamorphic and structures have not been carefully mapped. In some areas such as the Hot Springs window In North Carolina the structure is similar to the folded Appalachlans.

The southeasternmost province of the Appalachians is the Pledmont. Except In areas such as Warm Springs, Georgla, which are structurely gimflar to the folded Appalachians, the Pledmont is of little geothermal interest, except as a key to inferring subsurface geology beneath the Atlantic Coastal Plain. The Atlantic Coastal plain is a wedge of sediments thickening toward the ocean underlain by basement rocks thought to be similar to the Pledmont.

The northern portion of the Appalachians is generally similar to the Piedmont and Blue Ridge. A narrow band of rocks along the western edge structurally resemble the folded Appalachians.

The Trans Pecos basin is part of the basin and range structual province and is generally block faulted mountains surrounded by desert basins. The most obvious manifestations of the earth's thermal energy are in areas of recent volcanism and tectonlsm. The eastern U.S. Is not blessed with such activity.

The search for geothermal resources in the east requires more subtle interpretation of geology.

Slide 2 (Figure 11)

The known occurrence of geothermal energy in the eastern states can be divided 
GRUY FEDERAL. INC.

\author{
Into four categories: \\ (Warm Spxings - shown as dots) \\ 1. The warm springs in the east appear to be assoclated with a \\ common geologic setting--steeply dipping rock units, comonly \\ quartzites and transverse fractures or faults.
}

The Importance of fault control is not clear. Faulting is present In all of the warm spring areas but no springs are known to discharge from fault zones--except those inferred by studies of linears. The steeply dipping beds appear to be the most important factor. Warm springs in the basin and range are commonly associated with fault zones. The faulting is relatively recent.

There is some evidence in the west that recurrent seismic activity is necessary to keep thermal springs active. Faults as old as most of those in the east have had ample time to be sealed unless more recent movement has taken place.

2. Aquifers containing abnormally warm waters for the depth of occurrence. Abnormally warm aquifers are known or inferred to exist in several areas of the east. The most Important area is along the Balcones and Luling-Mexia Talco fault zones. Other areas are thought to overlle several of the deep geopressured Gulf Coast reservolrs.

Fluid movement may be related to movement along fault zones or updip along the coastal plain sediments.

Another extensive area of abnormally warm water is the Smackover brine field in southern Arkansas. Maximum temperatures measured are about $140^{\circ} \mathrm{C}$ at about $3 \mathrm{~km}$.

A large area of warm water is Inferred to underlie western Nebraska. The Nebraska Survey is beginning to study this area. 
GRUY FEDERAL. INC.

3. Radioactive heat producing granite plutons beneath a thick coverIng of low conductivity sediments.

Radioactive plutons in the Atlantic Coastal Plain are currently under investigation by VPI \& SU.

4. Deep sedimentary basins with normal temperature gradients.

The deep sedimentary basins offer some potential for geothermal development, but only in areas where high heat flow, low conductivity, or vertical movement of flulds provide above average thermal gradients. Areas of normal gradients require excessive depths for adequate temperatures and are currently uneconomic.

The three likely causes of elevated subsurface temperatures in the eastern United States are:

1. Granitic plutons (igneous intrusions) enriched in uranium and thorium that produce elevated heat flow as the result of radioactive decay.

2. Thick sediments of low heat conductivity that cause above-average. thermal gradients by allowing the accumulation of heat below them.

3. Movement of deep waters upward along rock layers or through faults and fractures to produce accumulations of warm water in reservoirs relatively near the surface or warm springs at the surface.

Temperature gradients, heat flow, geochemistry, selsmic activity, and reglonal geology yield the principal clues to such thermal accumulations.

Slidë 3 (Figure 8) 
GRUY FEDERAL. INC.

Inferences about geothermal recources can be made by examination of temperature gradients. The only regional compilation currently available is the AAPG-USGS subsurface temperature map. A generaliza tion of that map is now projected. The green areas indicategradients above $1.60 \mathrm{~F} / 100$ feet and the yel1ow areas indicate gradients greater than 2.00F/100 feet. Its accuracy is widely questioned, but it should provide a general guide to areas of possible elevated subsurface temperatures.

Geochemical studies, particularly regional studies such as those of Swanberg and Morgan are also valuable reconnaissance tools. They have used silica concentrations in ground water to estimate regional heat flow.

The ideal situation for the occurrence of geothermal resources in the east is a combination of high heat flow and low conductivity. This is most 1ikely where a radioactive pluton is covered by a thick cover of low conductivity sediments. The existence of plutons in the subsurface is expected but exact locations are generally unknown in many areas of the east. Sediment thicknesses are better known.

Slide 4 (Figure 5)

This slide showns areas where thick sediments are present. Thickest sediments occur in the deep basins of the Ouachita region and the Appalachian, Michigan and Illinois basins as well as the Gulf Coast. Only a small portion of the Atlantic Coastal plain is thought to have sediments thicker than 5000 feet. The lowest conductivities are expected in the unconsolidated sediments of the coastal plains.

Slide 5 (Figure 13)

Other areas of relatively low conductivity sediments are those areas under lain by thick sequences of Devonian Shale. 
GRUY FEDERAL. INC.

Elsewhere is the east rock conductivities are probably too high to yield high enough temperatures for utilization at depths which may be attained economically.

Slide 6, (Figure 14)

The coincidence $8^{f}$ sediments thicker than 5,000 feet and gradients greater than $1.6 \mathrm{~F} / 100$ feet is shown in red on this slide. Temperature data and sediment thicknesses are from publications of the AAPG and USGS. The work of costain and others indicates more potential in the Atlantic Coastal Plain than the older AAPG data. The southern half of the Delmarva peninsula and the stumpy point North Carolina areas should also be colored red.

S1ide 7, (Figure 10)

Major high temperature hydrothermal systems are usually assoclated with tectonically active areas. The eastern U.S. Is generally regarded as tectonically stable. However, some seismicity remains. (Explain map symbols). Several of the more Interesting zones in the east are the New Madrid, Missourl area and the trend extending from there towards the St. Lawrence River Valley and the midcontinent seismic trend.

The major zones of faulting in the east such as the boundary faults of the triassic basins and the 38th parallel fracture zone are not known to have elevated subsurface temperatures, except where seismic activity is still. present.

Slide 8, (FIgure 14) 
Both the AAPG - USGS subsurface temperature map and the geochemical modelIng of Swanberg and Morgan show colncidence between temperature gradient highs and historic selsmic activity. These areas are shown in green. These areas of coincidence include several of the areas where preliminary work has been done in the search for hot dry rock.

Movement of waters along bedding planes or fault zones appear to be the best method of heat transport in the eastern U.S.

Most warm springs known in the east are assoclated with steeply dipping beds. Such conditions are shown in blue and yellow and extend throughout the Ouachita structural belt, most of the folded Appalachlans, parts of the Blue RIdge and Pledmont, and the extension of the folded Appalachians along eastern New York.

Sand Springs and Lebanon Springs in eastern New York and western Massachusetts are probably of this origin. The anomoly at Saratoga Springs may also be related. $I ! m$ sure Jim Young will have more comments on this tomarrow.

This has been a very brief survey of the known and hypothetical geothermal resources in the east. Many of these areas will be discussed in more detall by others today and tomarrow. A more complete development of these thoughts is currently in review and hopefully will be avallable from Oak Ridge or NTIS in the next several months.

Thank you. 


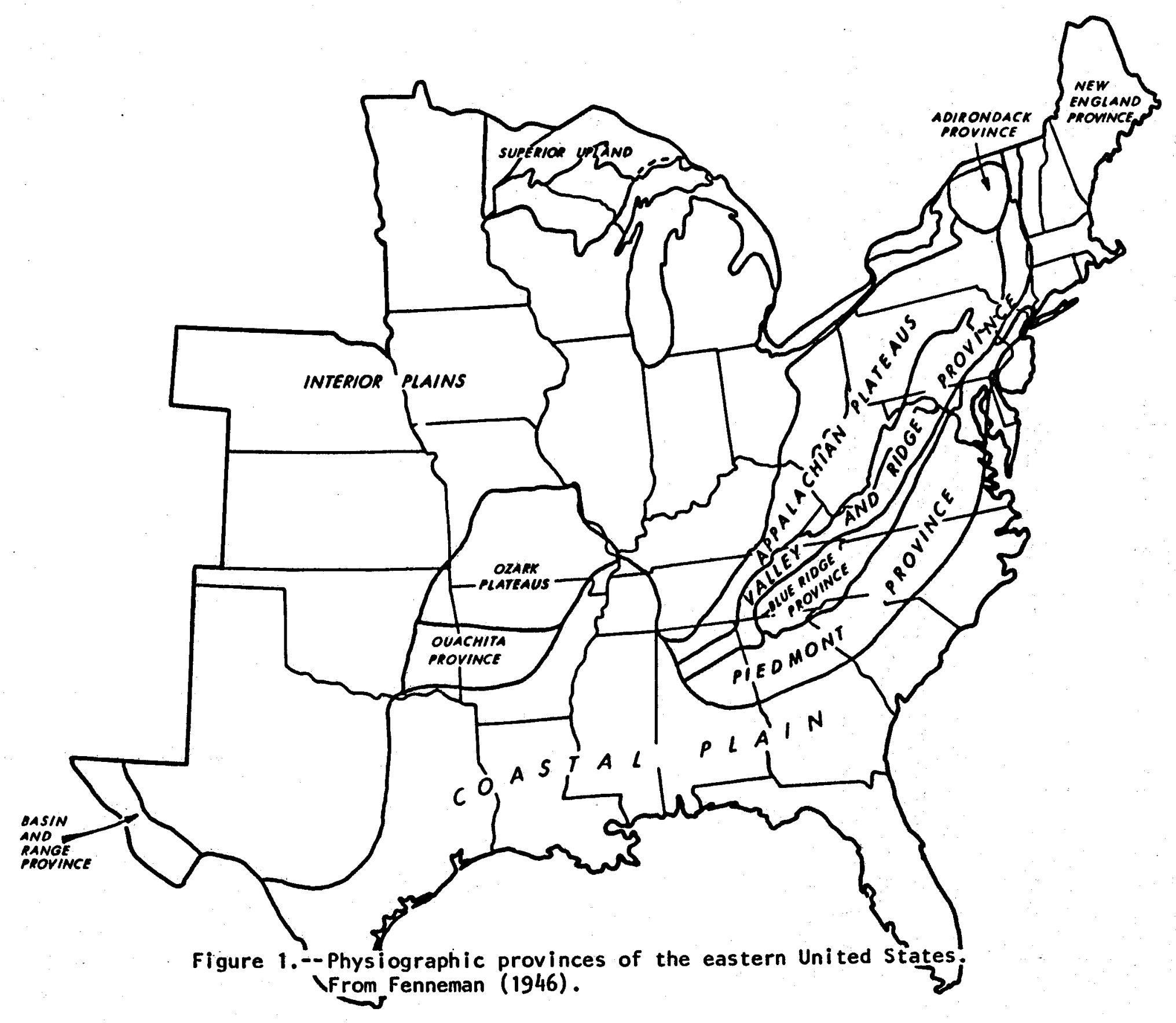

$\underset{\infty}{1}$ 


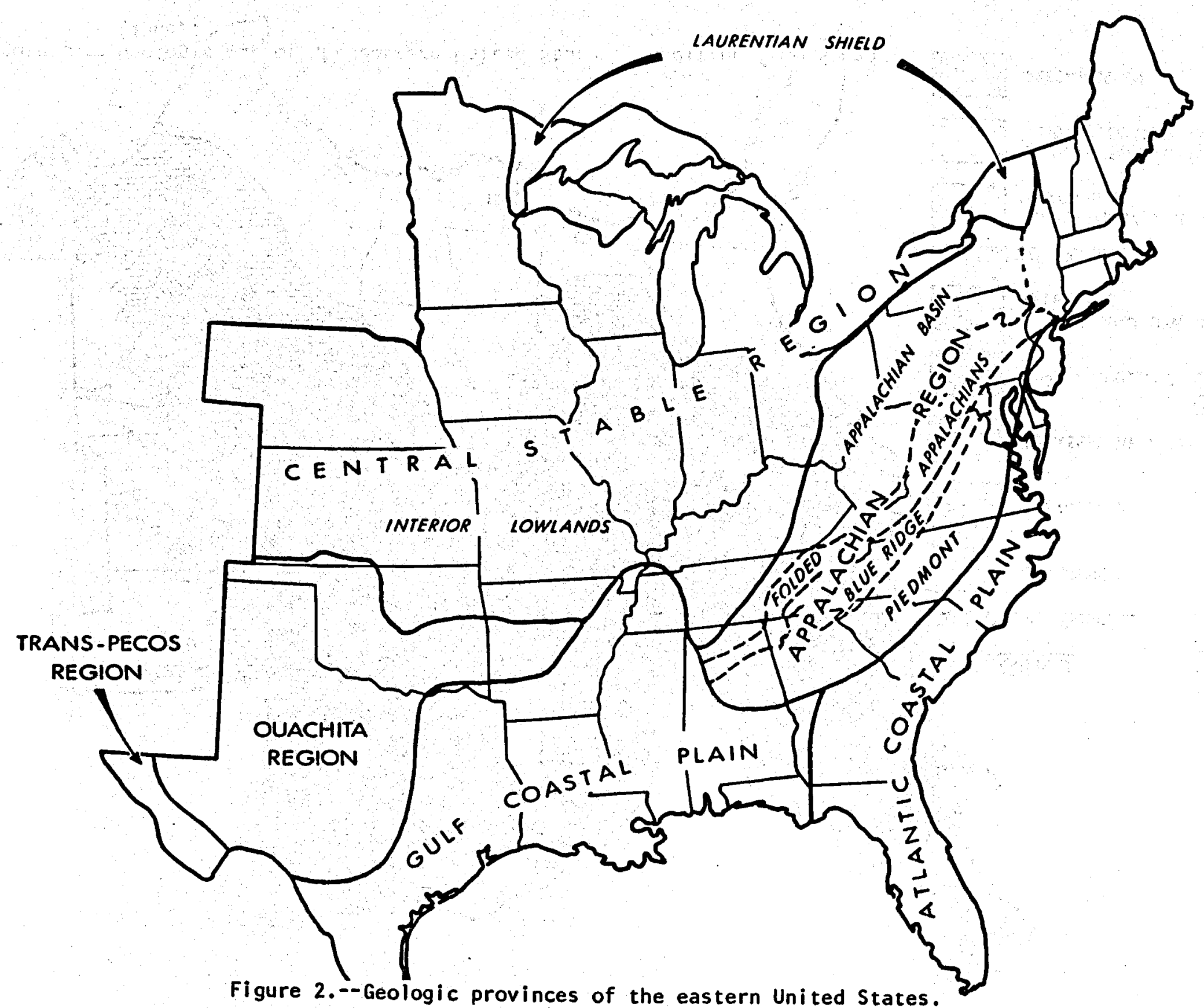




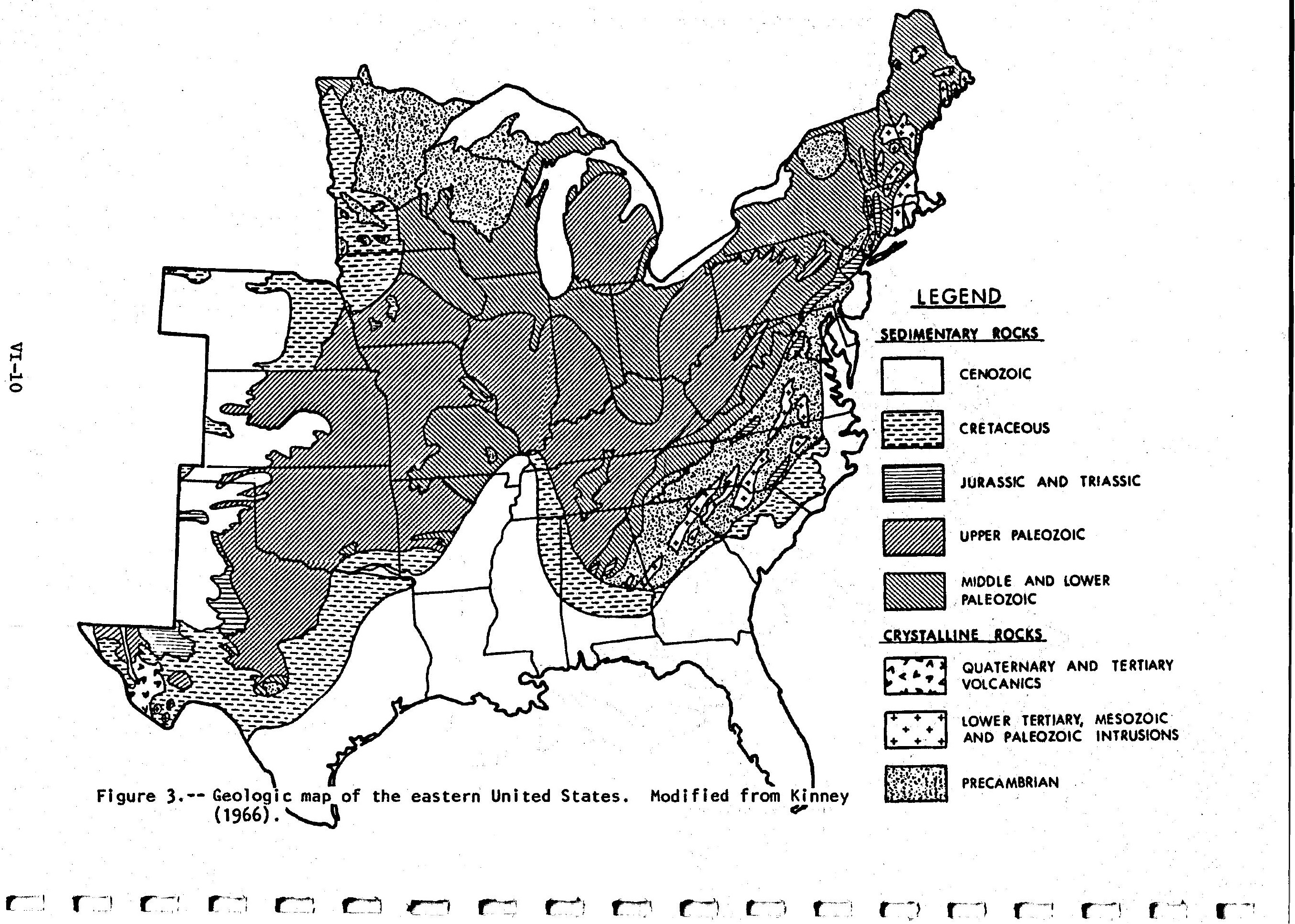





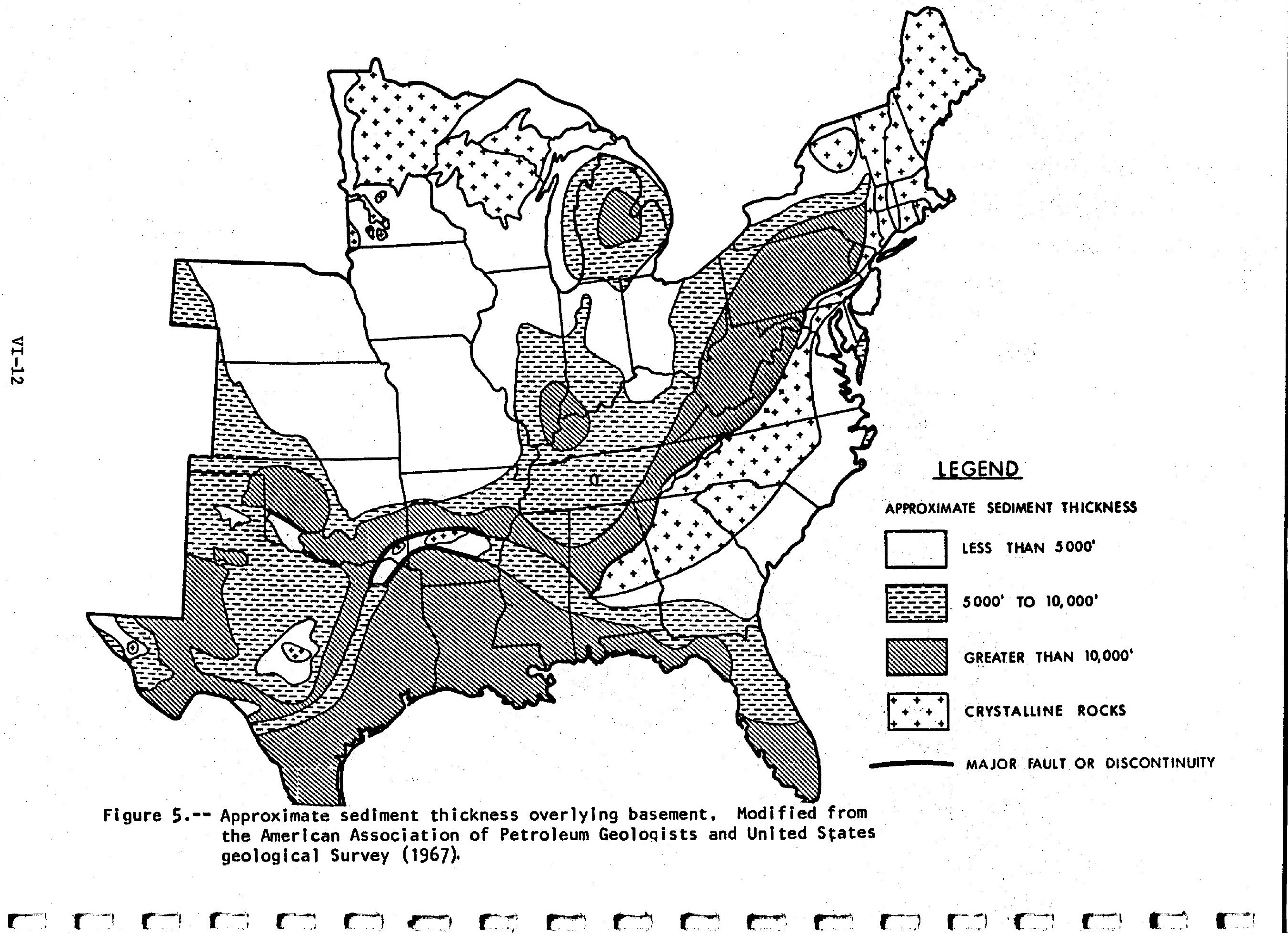




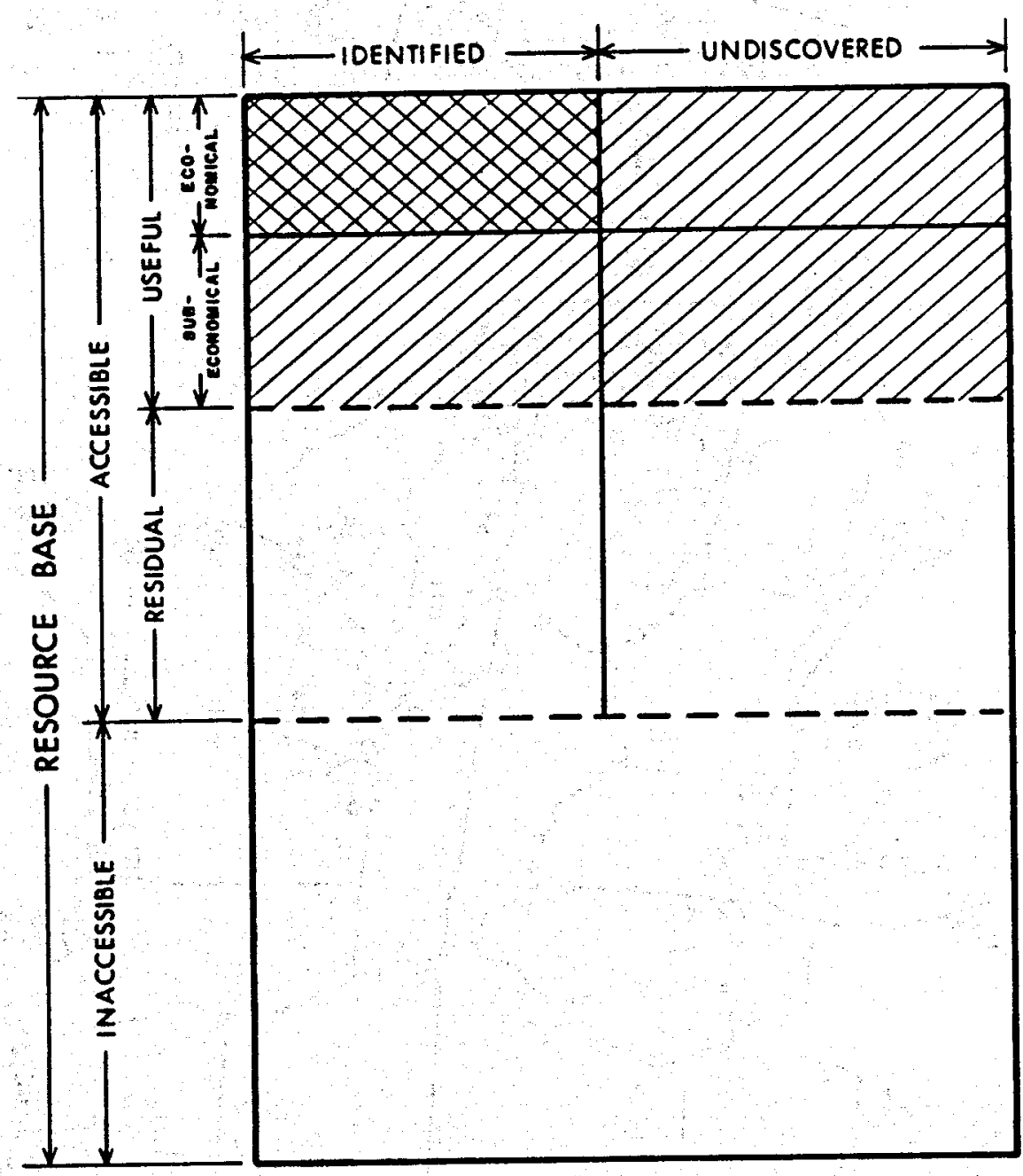

Figure 6.-- "Mckelvey" diagram showing the derivation of geothermal resource terminology by Muffler and Cataldi (1978). 


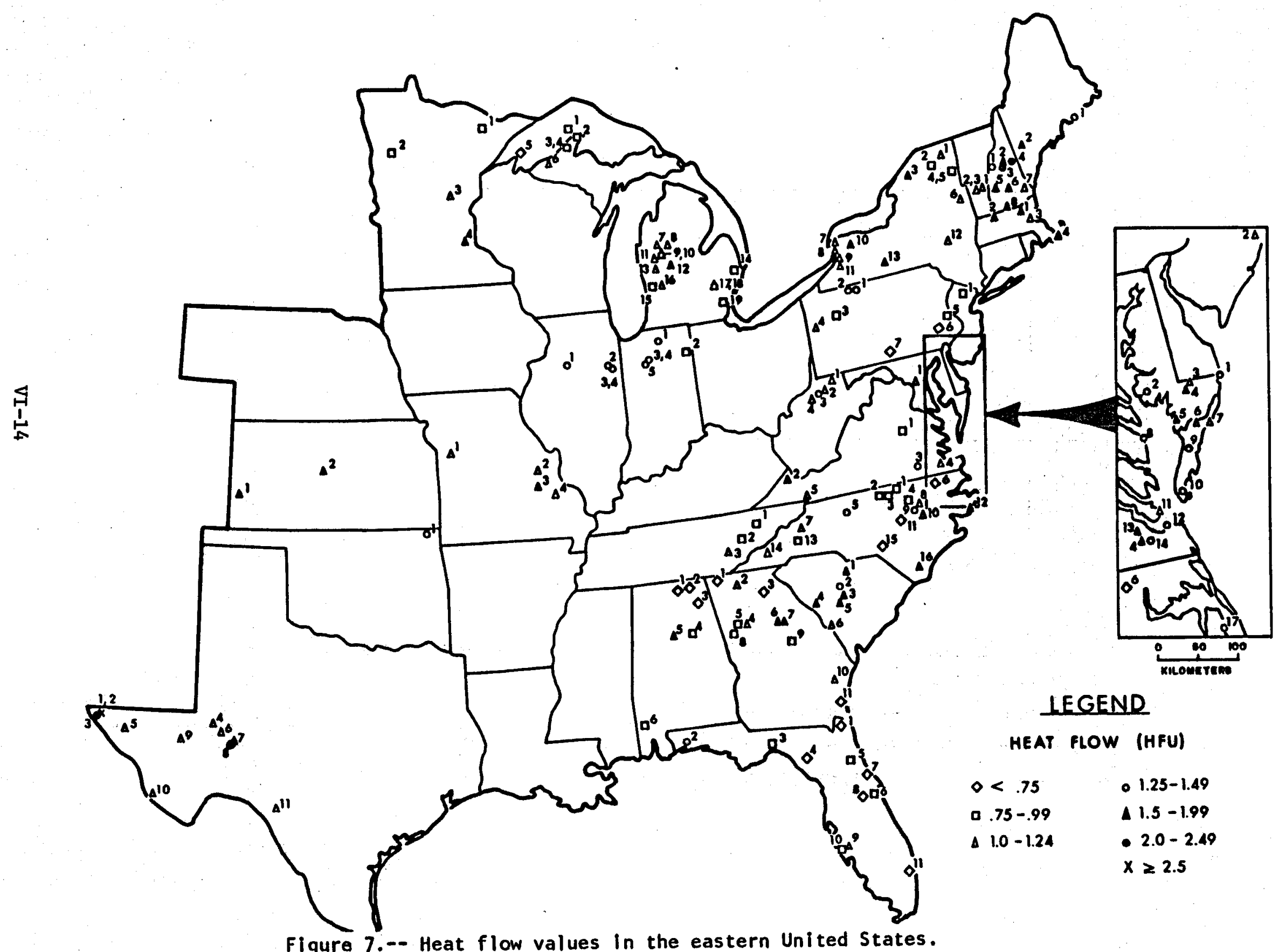

The numbers refer to Table 2. 

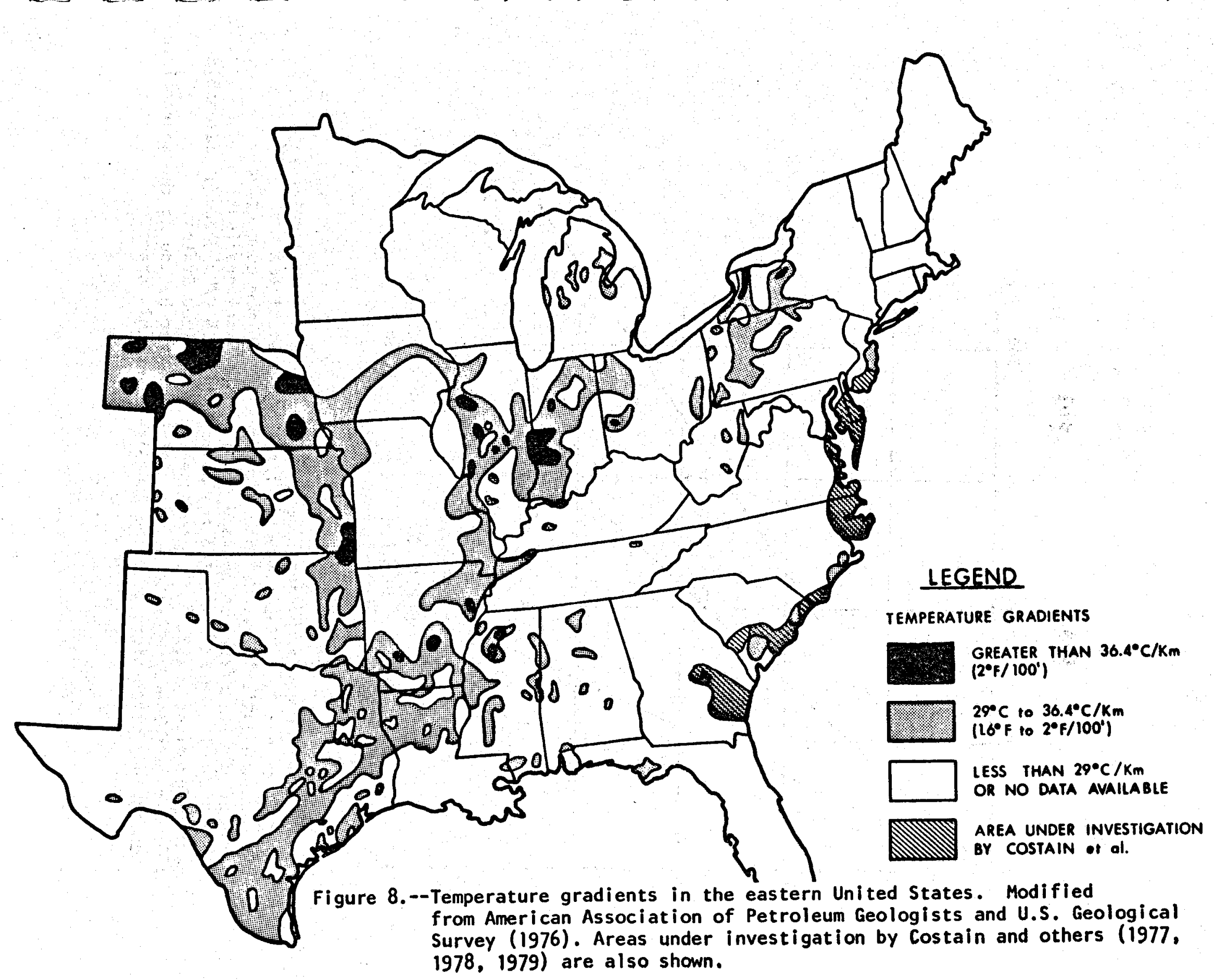


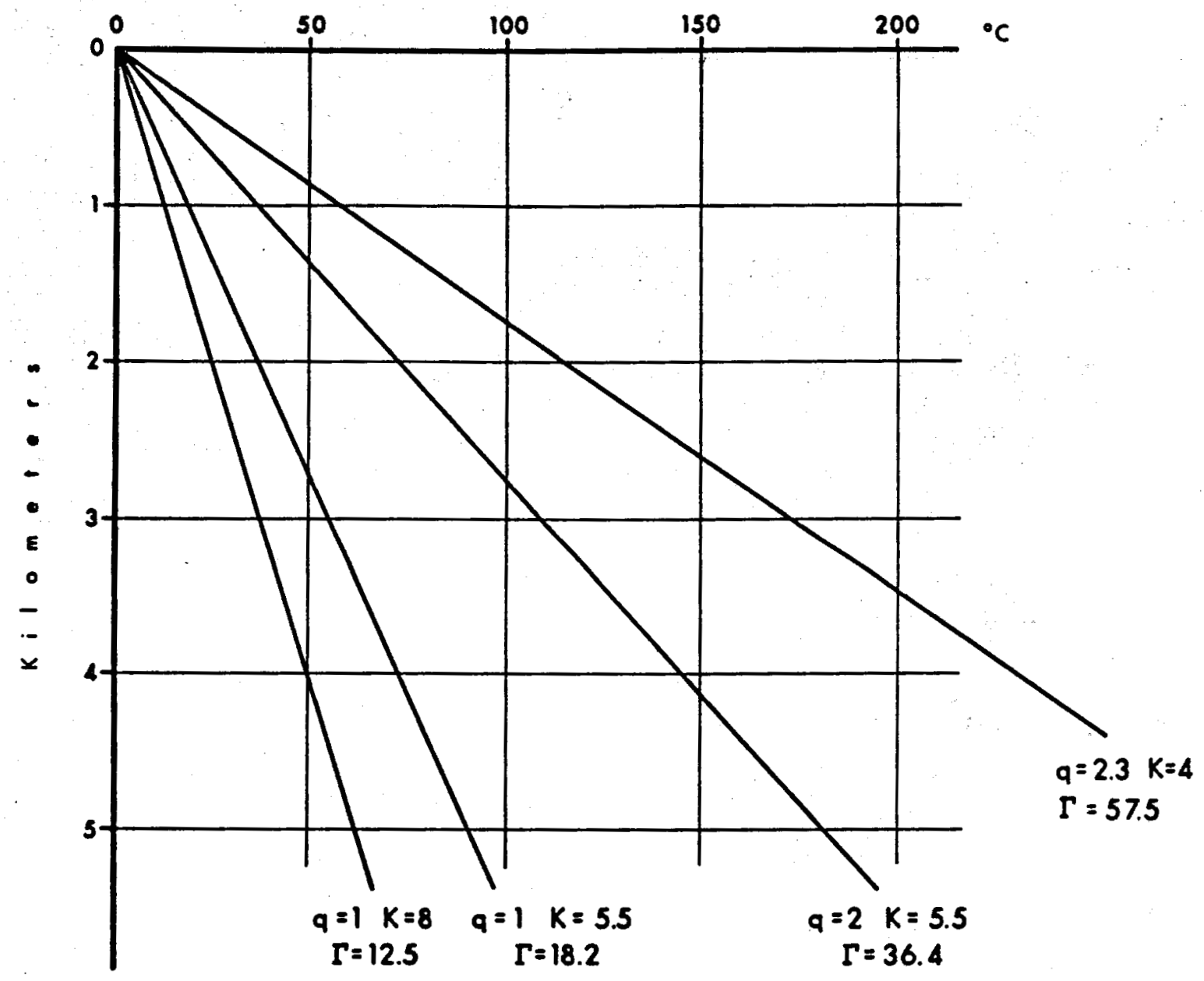

Figure 9.--Temperature increase with depth. Heat flow, and average conductivity $(K)$ are as specified. The slope of line $(\hat{\Gamma})$ is calculated from the equation $q=K \Gamma$. The lines show a reasonable minimum conductive gradient $\left(\Gamma=12.5^{\circ} \mathrm{C} / \mathrm{km}\right)$, an average stable continental gradient $\left(\Gamma=18.2^{\circ} \mathrm{C} / \mathrm{km}\right)$, a gradient twice the average $\left(\Gamma=36.4^{\circ} \mathrm{C} / \mathrm{km}\right)$, and a reasonable maximum gradient $\left(\Gamma=57.5^{\circ} \mathrm{C} / \mathrm{km}\right)$ for the eastern United States. Approximate subsurface temperatures can be obtained by adding the appropriate mean surface temperature to values obtained from this chart: 
con

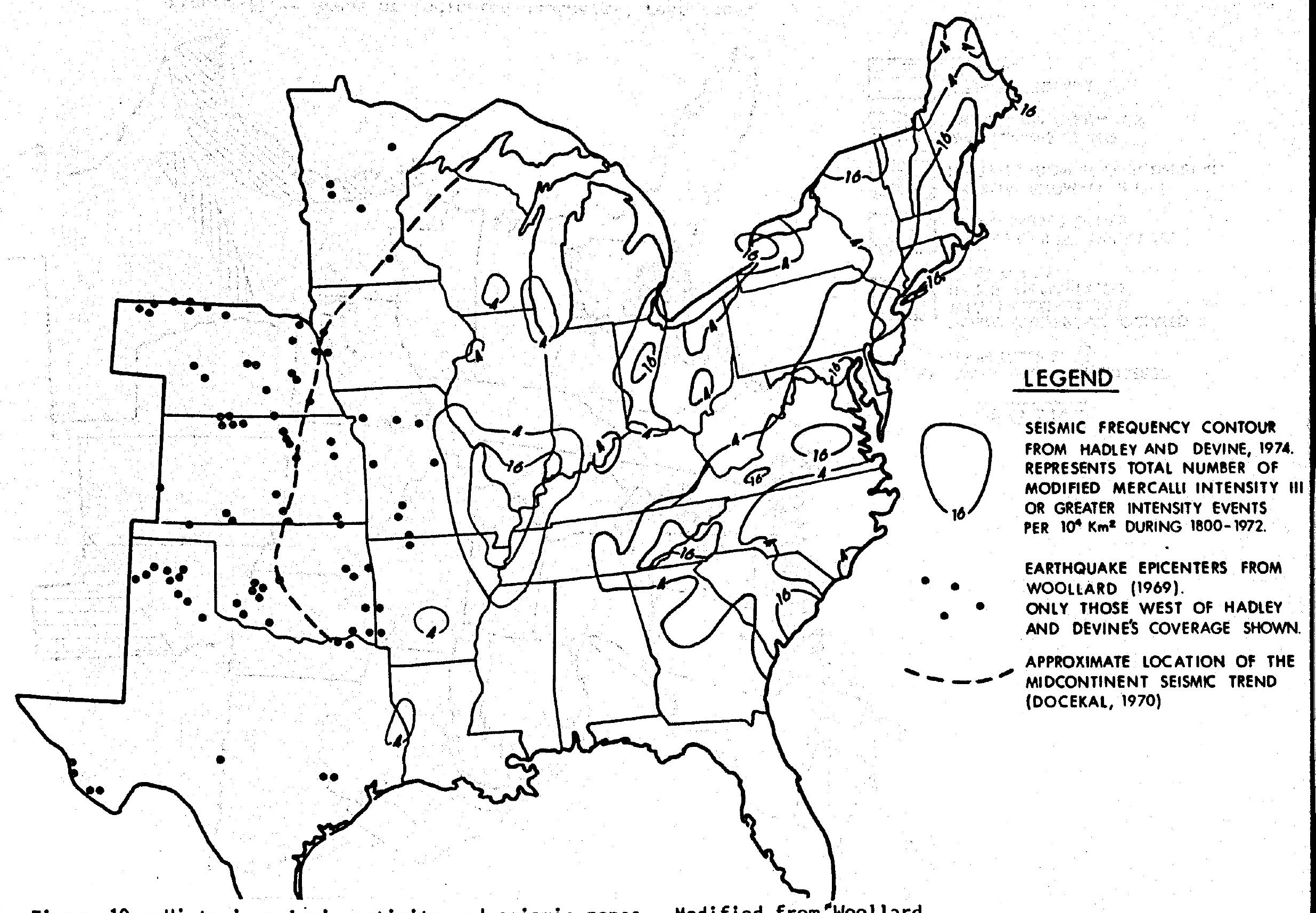

Figure 10.--Historic seismic activity and seismic zones. Modified from "Woollard (1969), Hadley and Devine (1974), and Docekal (1970). 


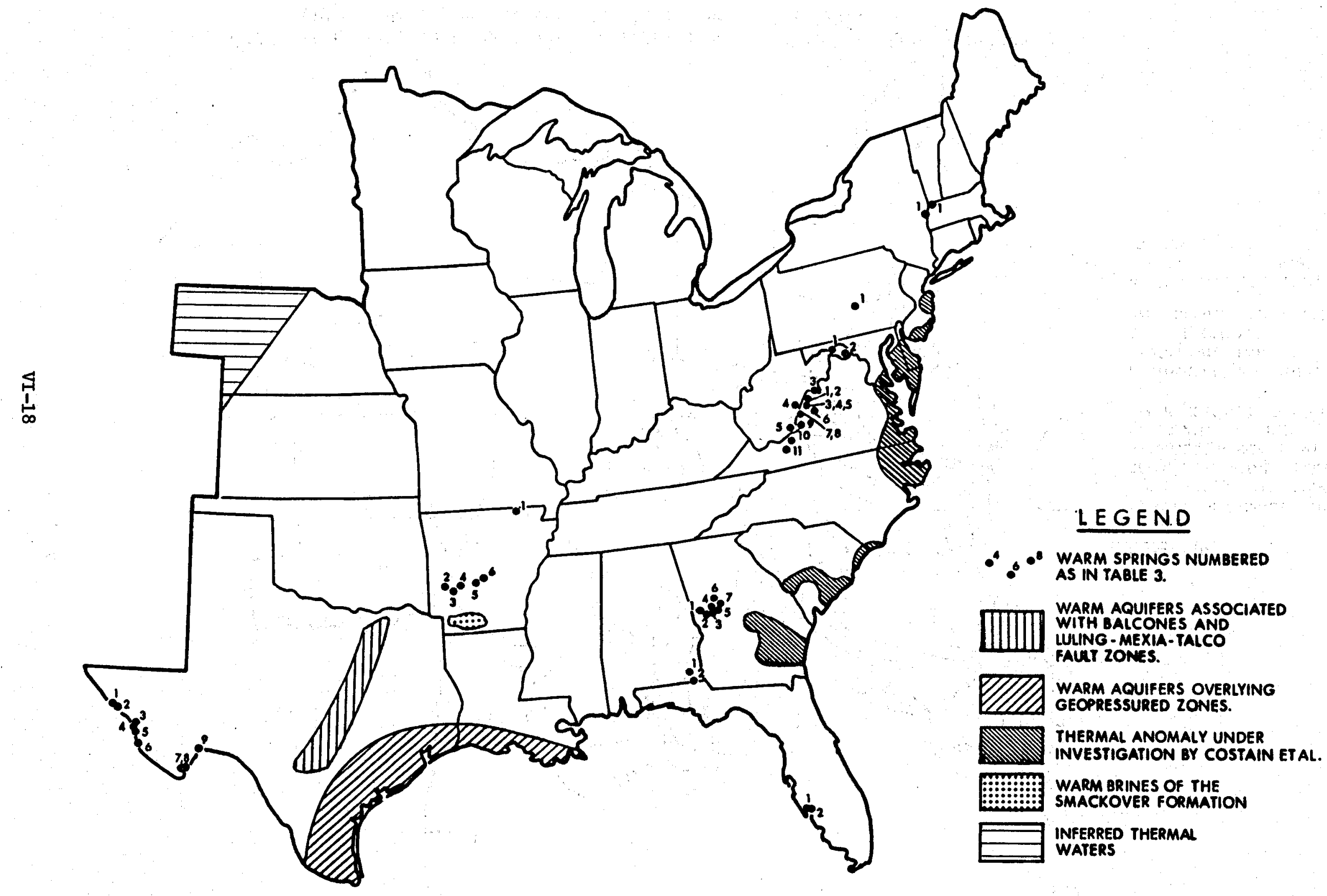

Figure 11.-- Areas of indicated geothermal resources. 


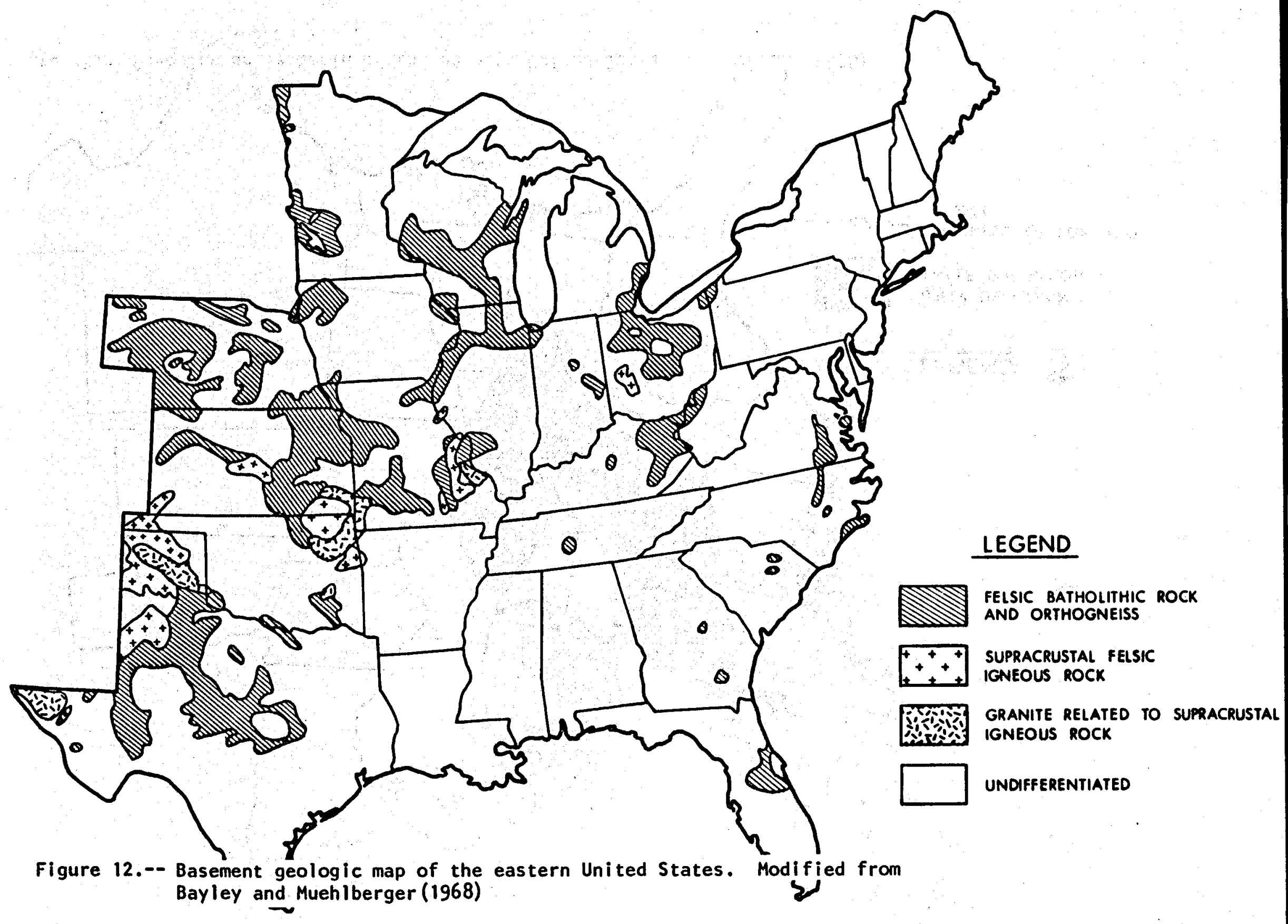




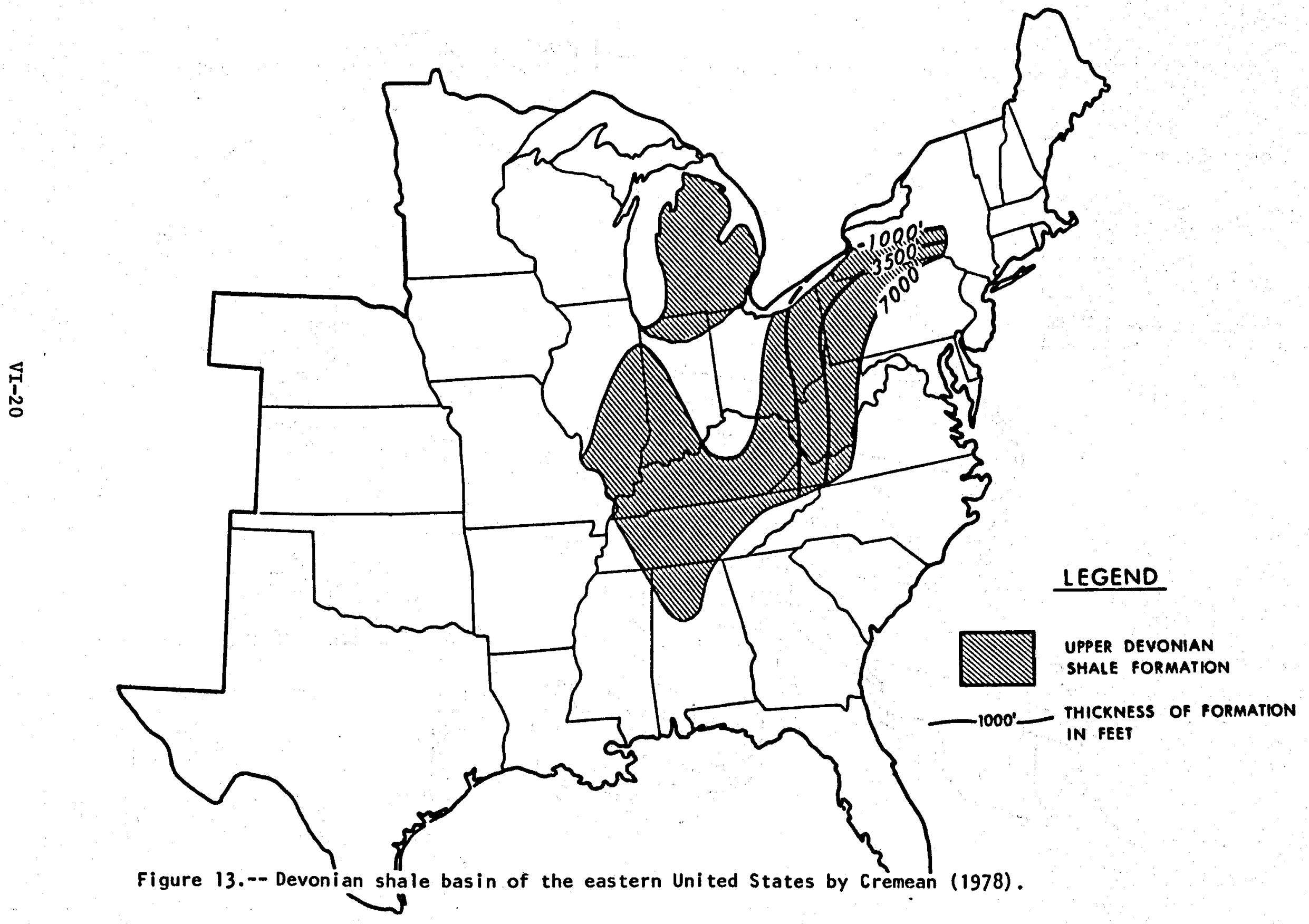




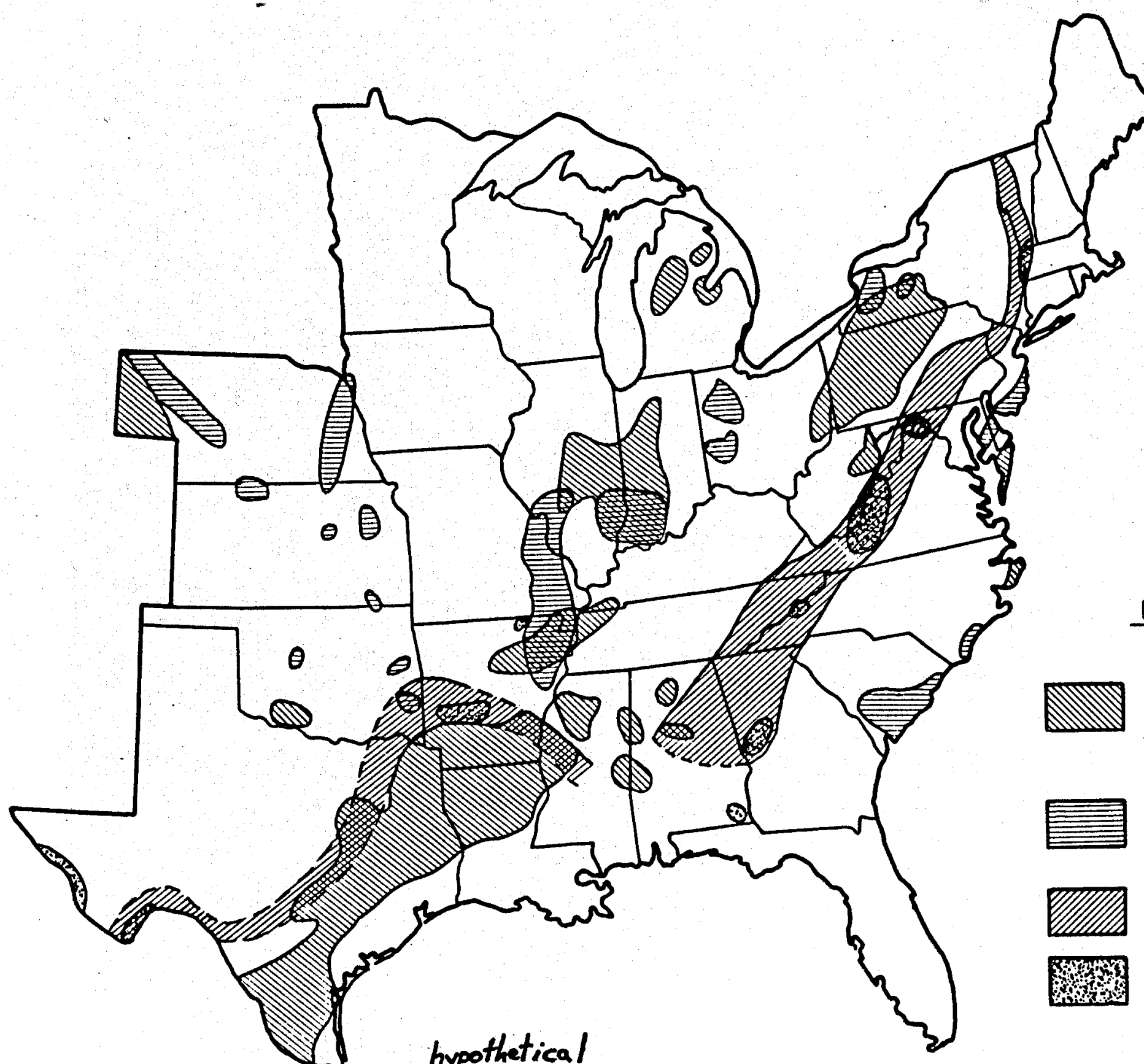

\section{LEGEND}

TEMPERATURE GRADIENTS GREATER THAN $29^{\circ} \mathrm{C} / \mathrm{Km} \quad\left(1.6^{\circ} \mathrm{F} / 100^{\prime}\right)$

AND SEDIMENTS THKCKER THAN $1.5 \mathrm{Km}\left(5000^{\prime}\right)$

TEMPERATURE GRADIENTS GREATER THAN $29^{\circ} \mathrm{C}\left(1.6^{\circ} \mathrm{F} / 100^{\prime}\right)$ AND SEISMICALLY ACTIVE

\section{GEOLOGY SIMILAR TO KNOWN} WARM SPRINGS AREAS

\section{WARM SPRINGS AREA}

Figure 14.-- Areas of geothermal potential in the eastern United States. 


\title{
Mid-Atlantic and Southeastern \\ Moderate Temperat ure Program - Geologic \\ Setting and Targeting Process
}

\author{
by \\ R. Gleason and J. Lambiase \\ Virginia Polytechnic Institute \\ and State University
}




\title{
Mid-At lantic and Southeastern Low-to-Moderate Temperature Program; Geologic Setting and Targeting Procedures
}

\author{
Richard J. Gleason \\ Joseph J. Lambiase \\ Samue1 S. Dashevsky \\ December 6, 1979 \\ Geothermal Program \\ Department of Geological Sciences \\ Virginia Polytechnic Institute and State University \\ Blacksburg, Virginia 24061
}

The exploration model (fig. 1) for geothermal resources in the Atlantic Coastal Plain postulates that granitic plutons with relatively high contents of radioactive elements (primarily $U, T$ Th and $K$ ) are locally present in the crystalline basement beneath the sediments of the Atlantic Coastal Plain. Radioactive decay of the se elements produces heat. Water saturated coastal plain sediments act as a blanketing. insulator, upwarping isotherms over the buried heat sources. The effectiveness of the Coastal Plain sediments as an insulator is a function of their thickness and thermal conductivity. Insulating capability increases with increasing thickness and decreasing thermal conductivity. Finally, large semiconfined or confined aquifers need to be present at depths appropriate for the temperature desired.

Detailed petrologic and heat production characterization of granitic plutons in the Piedmont Province west of the Coastal Plain provides a data base which may be extended with some modifications to the exploration for heat sources in the basement (extension of the Piedmont) below the Coastal plain. The most reliable data regarding basement lithology below the Coastal plain come from samples from drill holes which penetrate the basement surface. Unfortunately, such drill holes are concentrated near the shallow western edge of the Coastal Plain. In the deep part of the Coastal plain east of the Chesapeake Bay, only one basement hole has been drilled in virginia (fig, 2) and only 3 have been drilled in the Maryland - Delaware area (fig. 3), one of these was the recent geothermal test well at Crisfield, Maryland.

Because of the sparse basement drill-hole control, supplementary information regarding the character of basement must be obtained from regional gravity and aeromagnetic surveys. Granitic basement rock was encountered in a drill-hole located near the southeastern extension of a large elliptical negative gravity anomaly (fig. 4) which correlates with the Petersburg granite west of the Coastal Plain in central Virginia. Similarly, drill holes located over circular gravity lows in Dort, North Carolina and Portsmouth, Virginia (fig. 4) penetrated granites. Extrapolation of such known correlations between gravity patterns and lithology to the Chesapeake/Delmarva area suggests that a large elliptical negative gravity anomaly in the Chesapeake Bay (fig. 4) may be caused by a Petersburg-like granitic mass in the basement. 


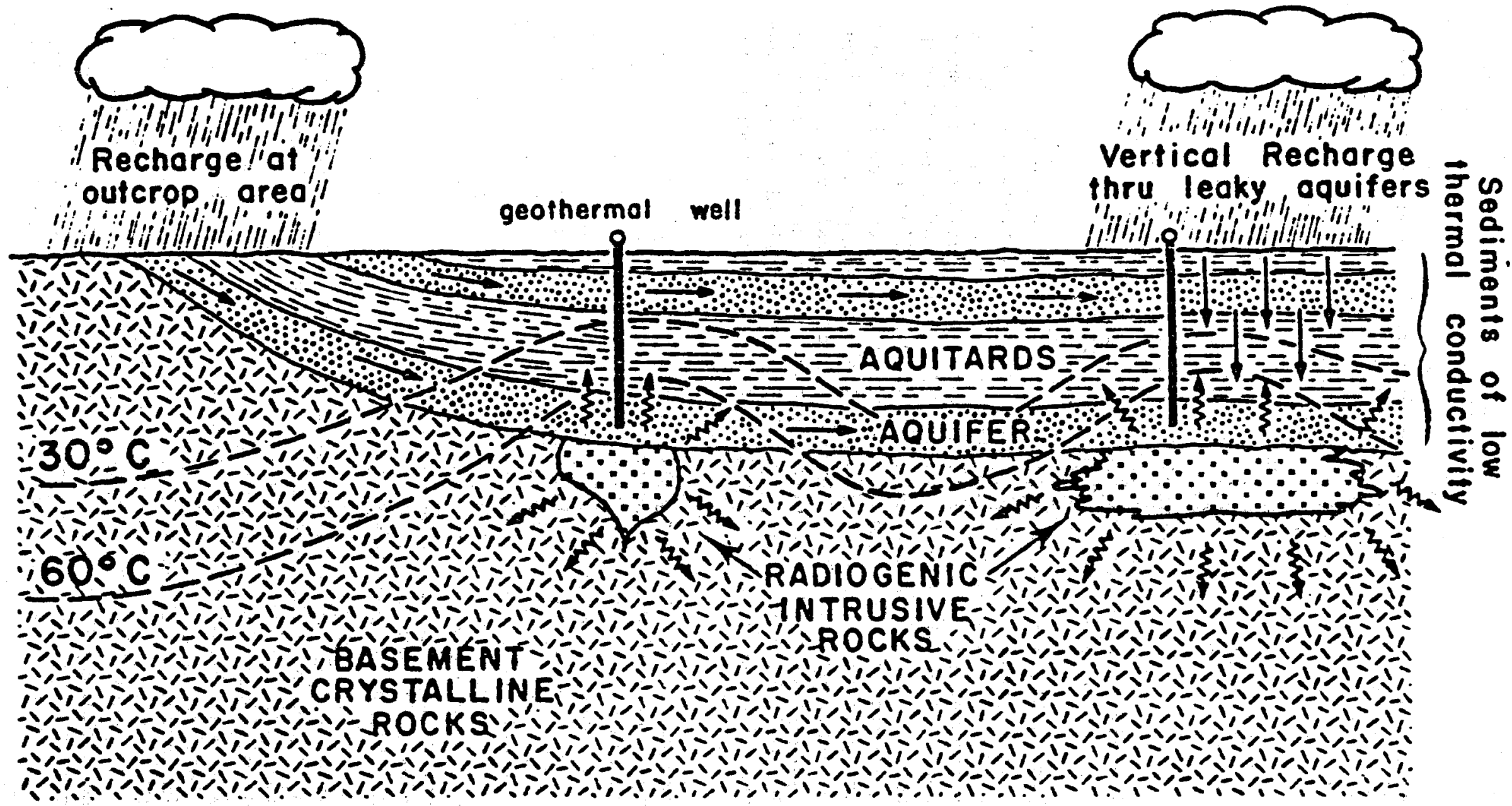

\section{GEOTHERMAL PROGRAM}

Figure 1. The exploration model for geothermal DEPARTMENT OF GEOLOGICAL SCIENCES resources in the Atlantic Coastal Plain. VA. POLYTECHINIC INST. AND STATE UNIV.
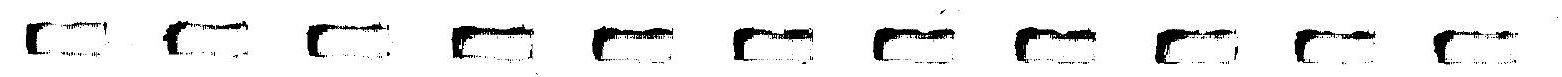

$r$

$\Gamma$

$r$


(1)

Lis

D

[

C

l

D

(

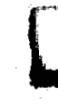

0

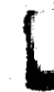

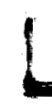

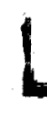
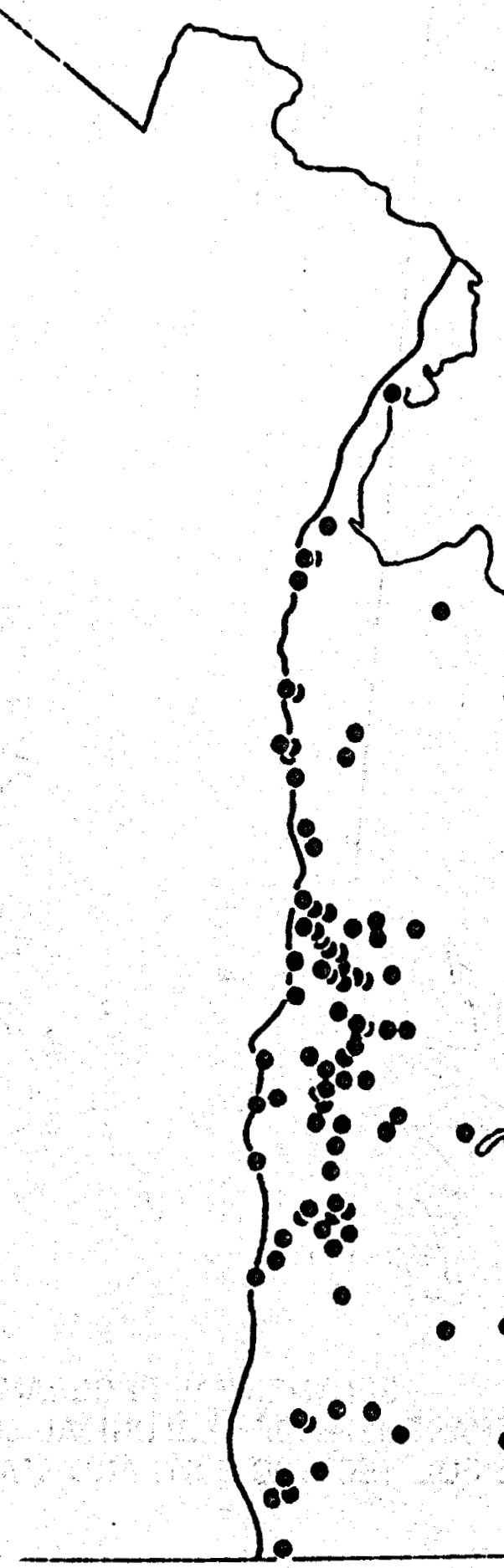

a

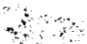

Figure 2.

Drill holes penetrating Basement in Virginia

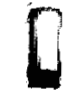

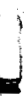

(3)
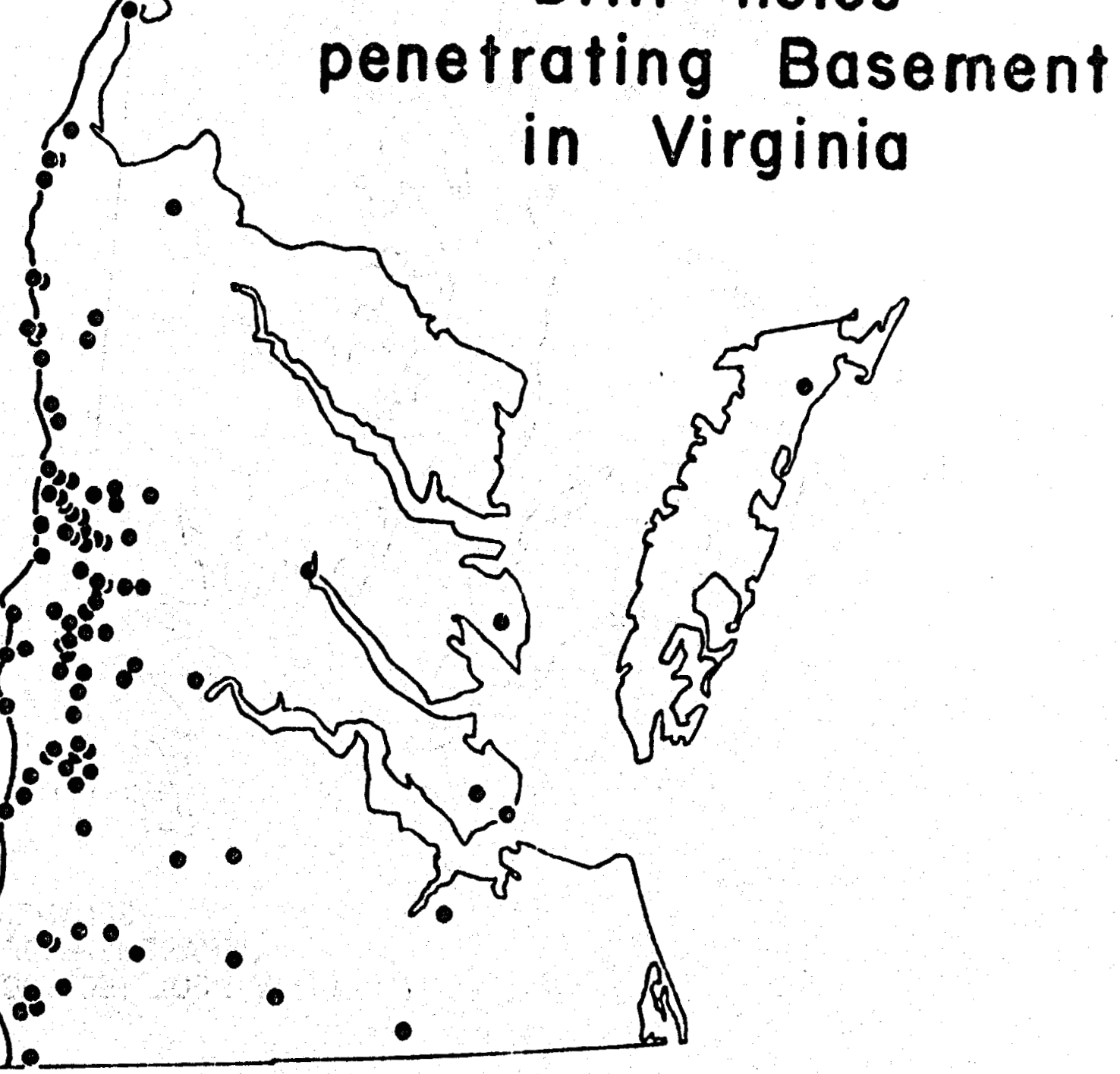

GEOTHERMAL PROGRAM

DEPARTMENT OF GEOLOGICAL SCIENCES

VA. POLYTECHNIC INST. AND STATE UNIV. 


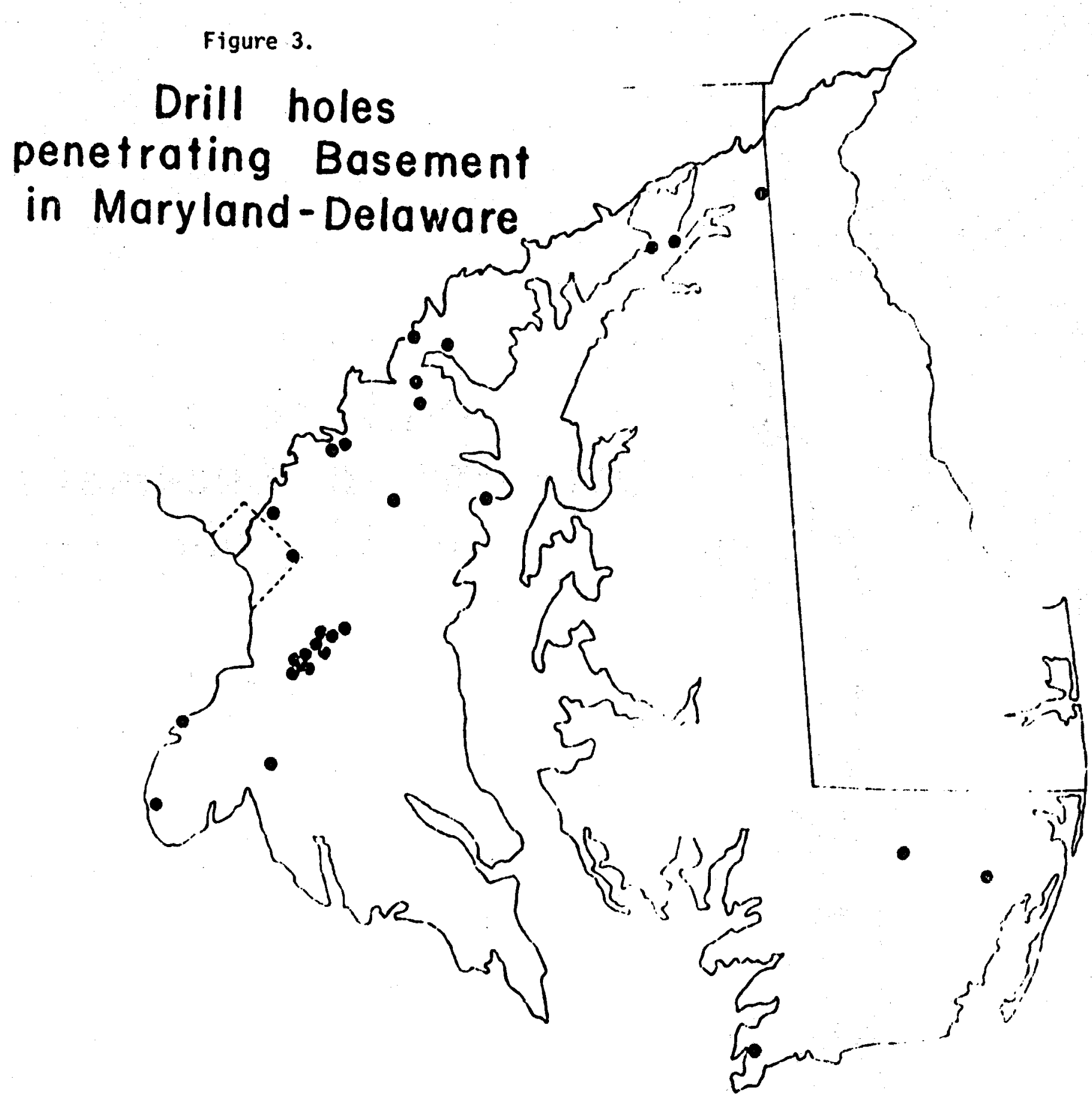

GEOTHERMAL PROGFIAM DEPARTMENT OF GEOLOGI:AL SCIENCE: VA. POLYTECHNIC INST. AND STATE UNI' 
Likewise, a small circular anomaly in the Wallops Island, Virginia area (fig. 4) may reflect the presence of a basement granitic stock.

A suite of fifty heat flow determination from 300-meter deep holes were drilled between New Jersey and North Carolina in 1978 . Heat flow measured over the Portsmouth granite discussed above was 77 $\mathrm{mW} / \mathrm{m}^{2}$, while heat flow measured in test hole fourteen miles to the west was a background level $49 \mathrm{~mW} / \mathrm{m}^{2}$. High heat production measured from the Portsmouth granite seems to confirm the radiogenic model at Portsmouth; a radioactive granite has intruded low heat-producing country rock, elevating the heat flow and therefore the temperature gradient.

Geothermal gradients and heat flow measurements are also relatively high in the Delmarva Peninsula - Chesapeake Bay area, suggesting a possible correlation between the Chesapeake Bay negative gravity anomaly and a heat source in the basement. Low heat-producing basement metavolcanic rocks obtained from the Crisfield test well support the interpretation that high heat flow measured in the we 11 must come from another source. Perhaps it is related to lateral heat flow from the Chesapeake Bay anomaly, or from granite and migmatite below the volcanics.

Ultimately, drill hole data, potential field data, heat flow data, and seismic reflection data will be combined to generate a basement lithology map from which more efficient exploration for potential granitic heat sources may proceed. At present, generalized approximations of such maps for the Coastal plain basement have been generated.

Work during the present fiscal year will include deepening two holes to basement on either side of the Portsmouth granite in order to verify the radiogenic model. In addition, a heat flow hole at Smith Point, Virginia, overlying the center of the Chesapeake gravity anomaly, will be extended to basement in order to determine the 1 ithology and heat production of the material responsible for the anomaly. The heat flow drilling program also will be extended into South Carolina and Georgia, with the drilling of several more test holes, some of which will be extended to basement to provide basement geologic control and heat production data in these areas.

Knowledge of depth to basement is a requirement for the estimation of temperatures obtainable at a given site. In general, the Coastal Plain sediments thicken from west to east. The Coastal Plain sediments are by no means a simple homoclinally dipping wedge, however, as evidenced by the existence of major arches and embayments (fig. 5) A generalized map of depth to basement below the coastal Plain such as figure 5 gives a first approximation of the location of thick sedimentary sequences which may be attractive for geothermal resource exploration.

The evaluation of geothermal potential at specific sites relies upon more refined basement depth estimates. By extrapolation from known depths to basement, a first approximation may be obtained. 
Figure 5. Depth to basement beneath the Atlantic Coastal Plain. Contours are in feet from ground surface.

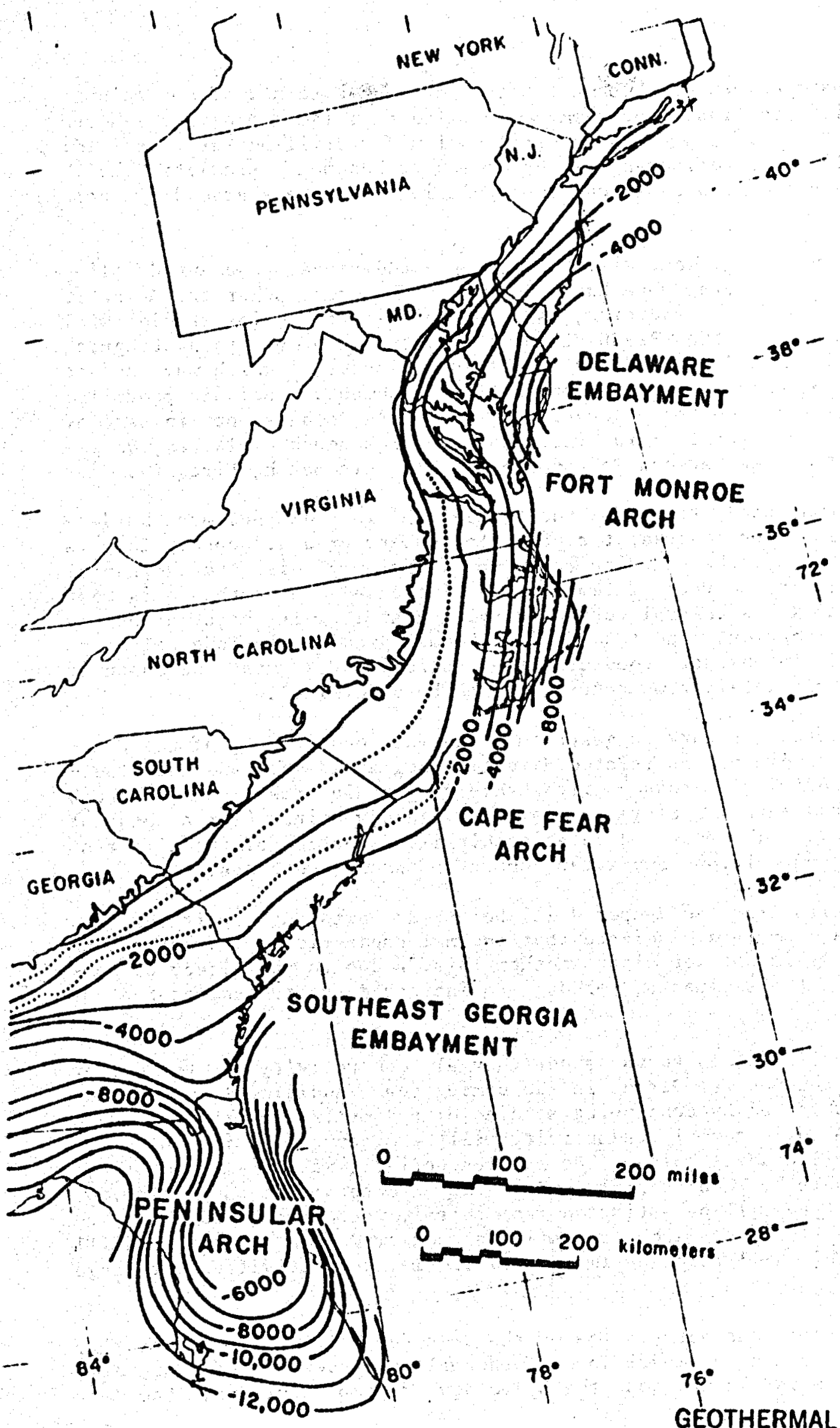


Approximate depth to basement also may be obtained from seismic reflection profiles. For example, a suite of seismic profiles was run on the Delmarva Peninsula in preparation for drilling at Crisfield; this allowed a refinement of the depth to basement prediction which previously had been based on extrapolation from the sparse drill-hole data.

During the present fiscal year, the additional basement drilling will provide several more known depths to basement under the Atlantic Coastal plain. In addition, several seismic reflection studies will be conducted by the VPI\&SU VIBROSEIS system in order to distinguish between indurated lower Coastal Plain sediments, which may act as acoustic basement, and true crystalline basement. Seismic profiling also will improve the understanding of depth to basement in several parts of the Coastal Plain, including the area south of Tasley, Virginia and the area between Portsmouth and Virginia Beach, Virginia.

Thermal conductivity of the coastal Plain sediments must be determined in order to predict accurately temperatures at depth. This is illustrated by the equation $\frac{\partial T}{\partial z}=\frac{q}{K}$.here $\frac{\partial T}{\partial z}$ is the geothermal gradient, or the rate of temperature increase with depth, $q$ is heat flow, and $K$ is thermal conductivity. Heat flow is constant at any specific location, and thus the geothermal gradient is inversely proportional to thermal conductivity; therefore, $K$ must be known if $\frac{\partial T}{\partial z}$ and ultimately temperature, are to be determined.

To date, our work suggests that thermal conductivity of the Coastal Plain sediments is related directly to grain size, and that thermal conductivity decreases with decreasing grain size. This causes higher gradients in clayey units than in sandy units (for a constant heat flow). The observed relationship is a function of the different chemical compositions and water content of sands and clays.

Results from two deeper drill holes, at Portsmouth, Virginia and Crisfield, Maryland, indicate that thermal conductivity increases with depth. It is not yet clear whether this is due to the effect of compaction of the sediments, or due to increased quartz sand content at depth.

Very little is known about thermal conductivity in the deeper parts of the Coastal Plain; in the coming year, additional information will be obtained by continuing studies of sediments from the Crisfield we11. Also, thermal conductivity will be measured in situ in fut ure Coastal Plain drill holes. Thermal conductivity will be mapped by the relationship between thermal conductivity and seismic $P$-wave velocity. Sediment type will be estimated from seismic velocities, and the thermal conductivity of each type will be confirmed from a control drill hole. This will allow estimation of thermal conductivities for large areas.

Reservoir characteristics of the deep Coastal Plain aquifers play a vital role in the model for geothermal resources. Unfortunately, very little is known about the hydrology of deep aquifers; the deep 
test at Crisfield, Maryland was the first hydrologic test of a deep Coastal Plain aquifer. It is imperative that the reservoir characteristics of these aquifers be better defined. In the coming year, open hole logs will be run in all Coastal plain drill holes to locate potential aquifers, and on-going hydrologic modeling studies will be continued.

The preceeding discussion outlines the approach and results to date of low to moderate temperature geothermal exploration on the At lantic Coastal Plain. Evaluation of the four criteria of the exploratory model indicates that there are heat sources in the crystalline basement beneath a sequence of Coastal Plain sediments that is sufficiently thick, and of sufficiently. low thermal conductivity to serve as a good insulator. The one deep test to date suggests that there probably are adequate reservoirs for a hydrothermal resource. However, additional research into the nature of each of these aspects is reguired before the geothermal resource potential of the At lantic Coastal plain can be understood fully. 
The Hot Dry Rock

\title{
Eastern Program
}

\author{
by \\ Dr. James C. Maxwell \\ University of California \\ Los Alamos Scientific Laboratory \\ Los Alamos, New Mexico
}




\section{HOT DRY ROCK RESOURCE BASE}
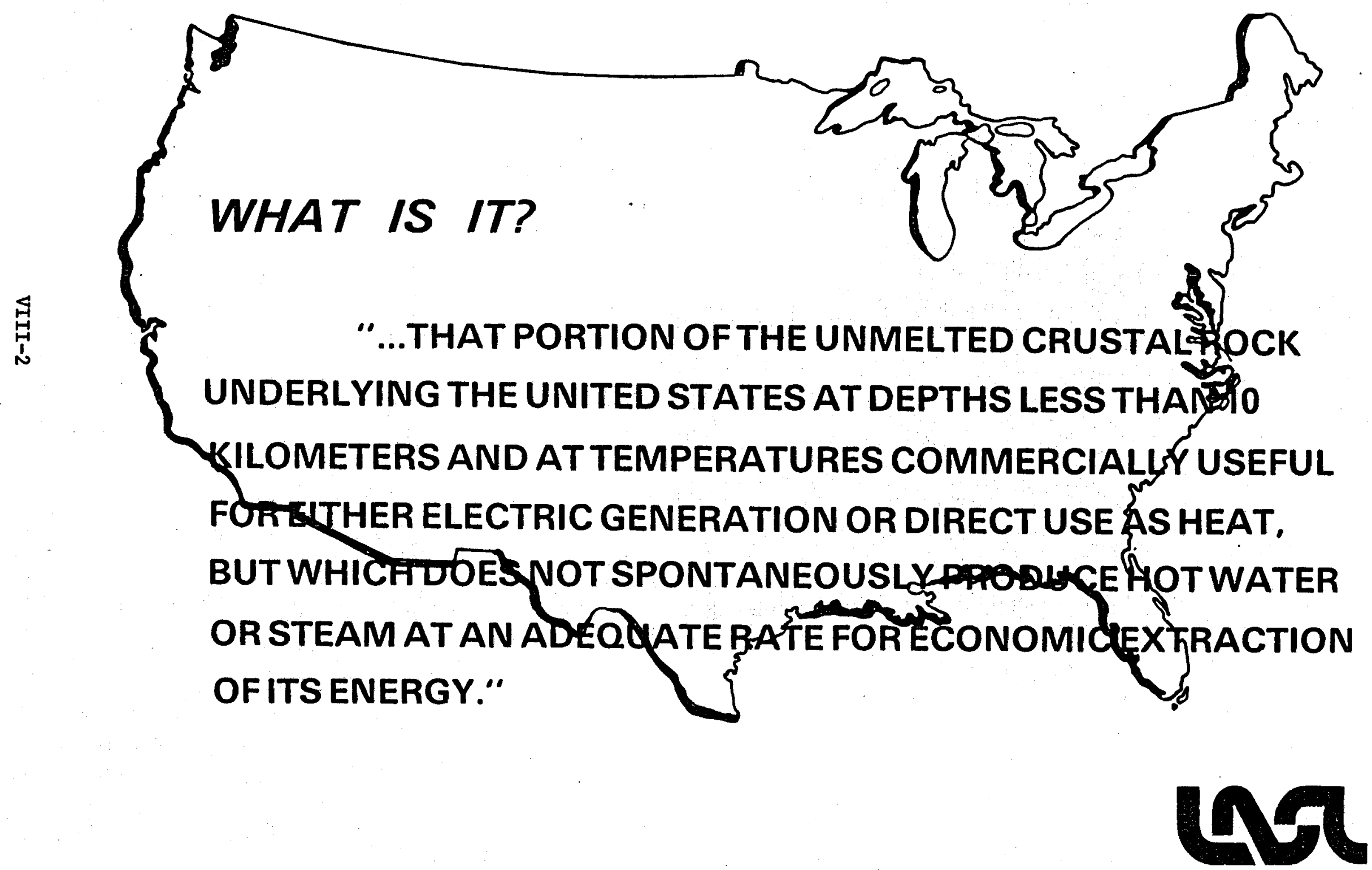

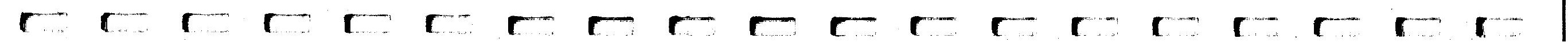




\title{
TYPES OF GEOTHERMAL SYSTEMS
}

\section{NATURAL}

\author{
HYDROTHERMAL \\ VAPOR DOMINATED (DRY STEAM) \\ LIQUID DOMINATED (SUPERHEATED WATER)
}

GEOPRESSURED (PRESSURIZED WATER WITH METHANE)

MAGMA (MOLTEN ROCK)

MAN-MADE

HOT DRY ROCK 


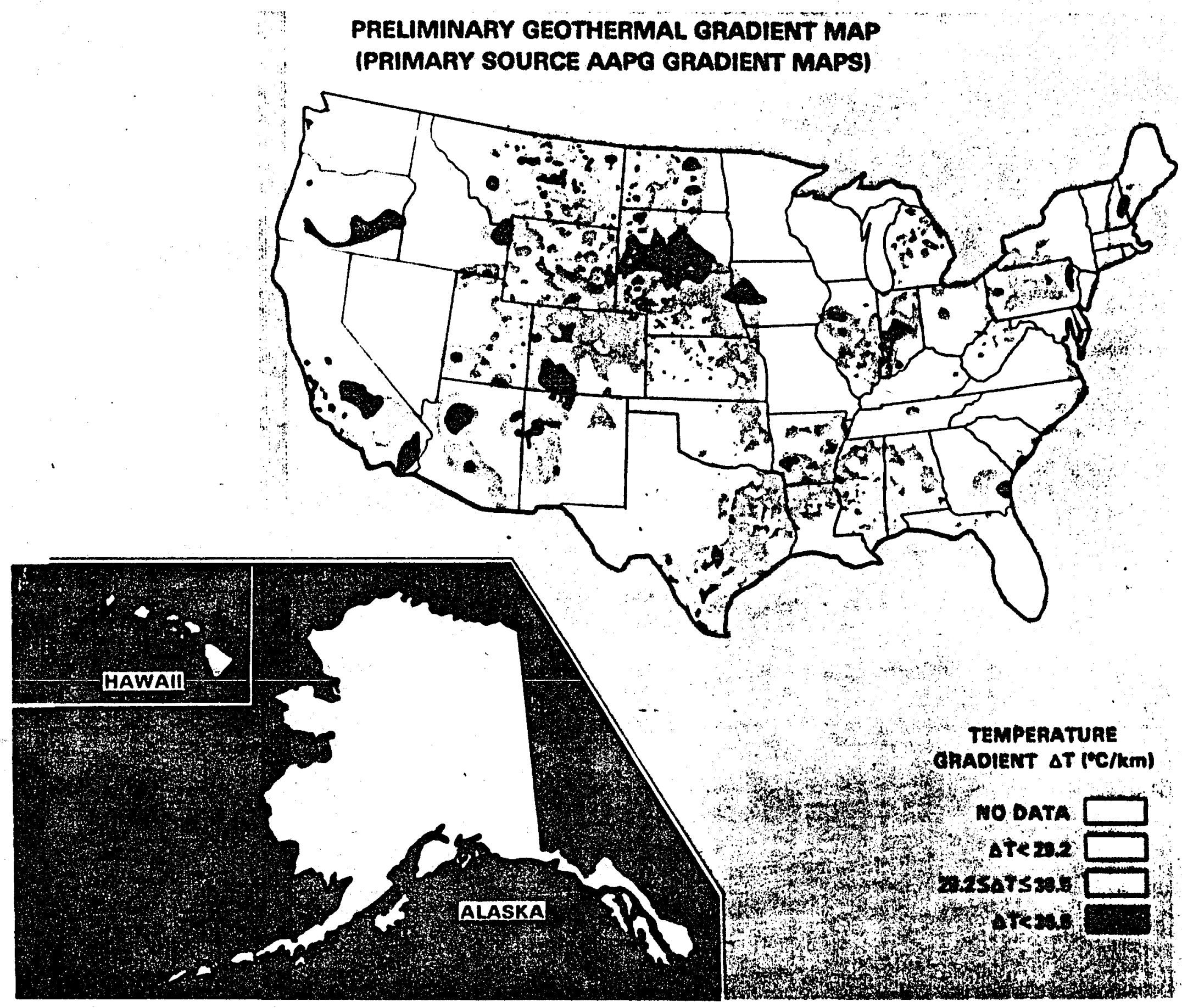





\section{PROGRESS IN SELECTION OF SITE 2}

- USING AVAILABLE DATA, TEN PRESENTLY-BEST-CHARACTERIZED THERMAL ANOMALY AREAS WERE STUDIED, AND PRESENTATIONS ON THESE AREAS WERE MADE TO PDC SITE SELECTION COMMITTEE (SSC) IN FEB. 1979.

- SSC THEN MADE PRIORITIZED RECOMMENDATIONS TO HDR PROGRAM OFFICE.

- HDR PROGRAM OFFICE STUDIED SSC RECOMMENDATIONS AND PROPOSED TWO "TARGET PROSPECTS" TO DGE:

1. CRISFIELD-WALLOPS ISLAND ("CRIS-WAL") AREA, MD-VA.

2. WESTERN SNAKE RIVER PLAIN ("BOISE") AREA, ID.

- CRIS-WAL AND BOISE PROSPECTS WERE APPROVED FOR DETAILED INVESTIGATION BY DGE IN MARCH 1979.

- CONTRACTORS hAVE BEEN SELECTED TO CONDUCT GEOPHYSICAL INVESTIGATION OF TARGET PROSPECTS DURING 1979.

$4 a$

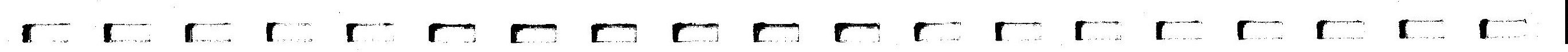




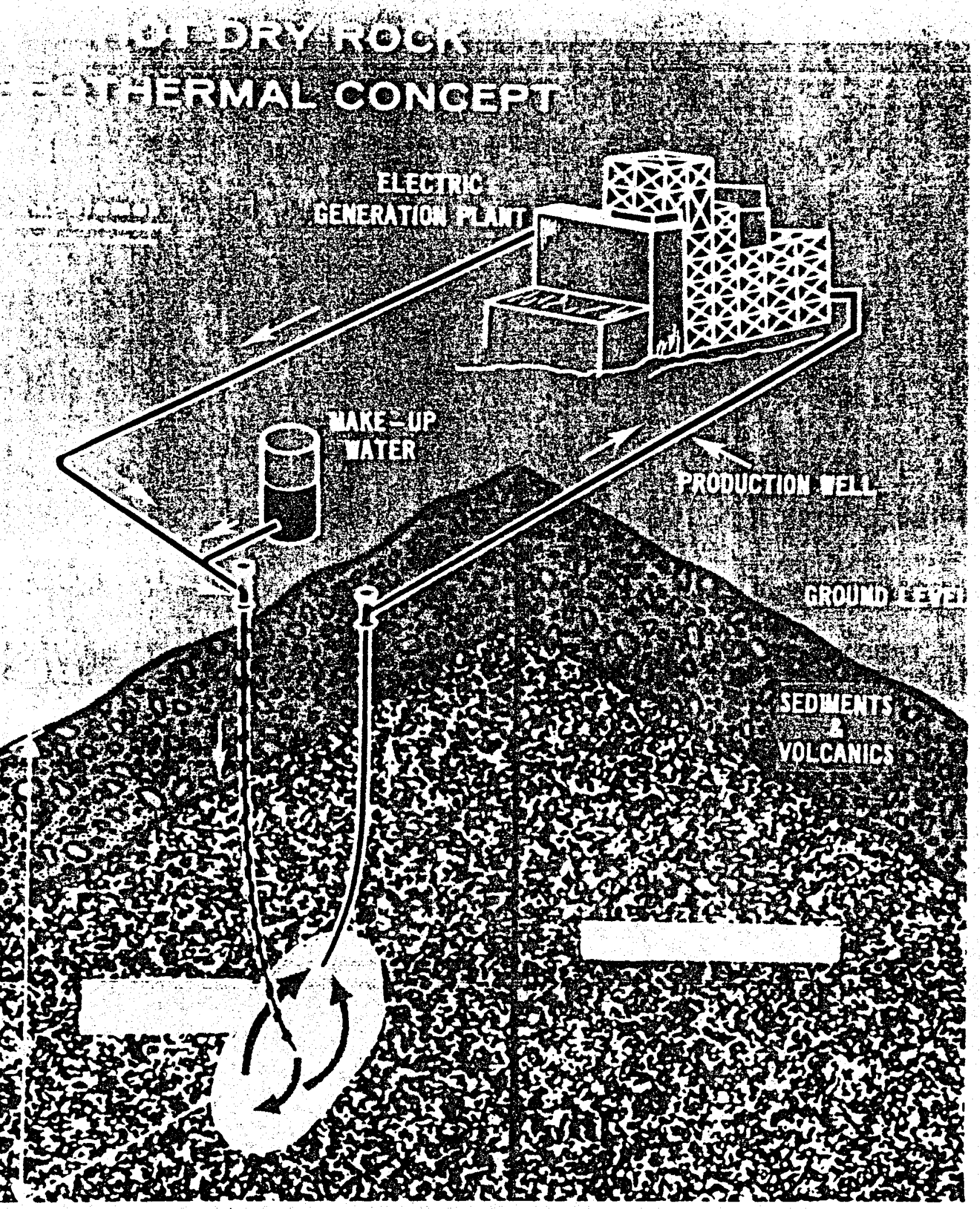




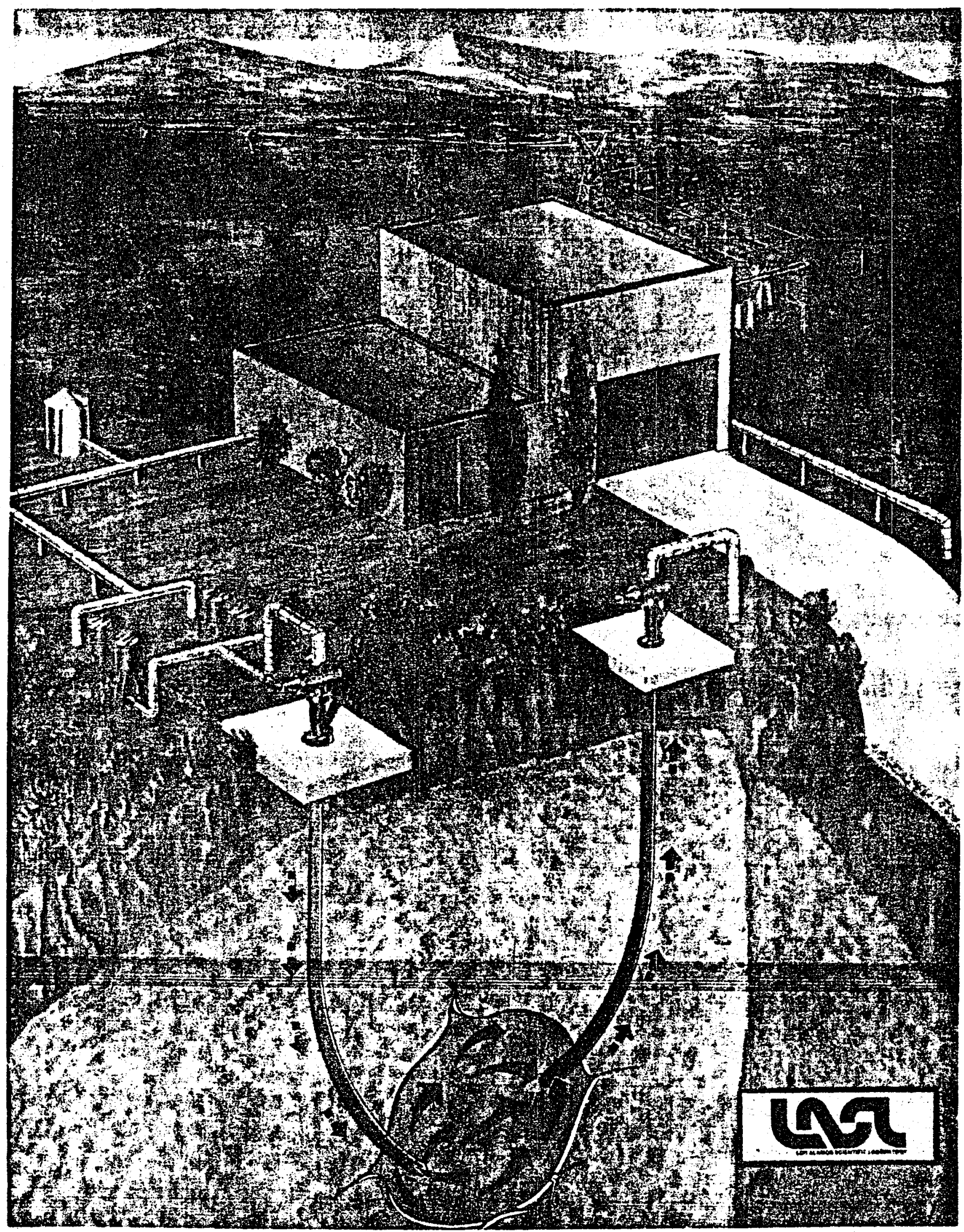





\section{ENVIRONMENTAL SURVEILLANCE RESULTS TO DATE}

NO DETECTABLE INDUCED SEISMICITY

NO DETECTABLE HYDROLOGIC IMPACTS

NO OBSERVABLE MICROCLIMATOLOGICAL EFFECTS

MINIMAL DISTURBANCE OF LAND AND

OF LOCAL FLORA AND FAUNA

LOW NOISE LEVELS

LOW LEVELS OF NOCTURNAL ILLUMINATION

NEGLIGIBLE EMISSIONS

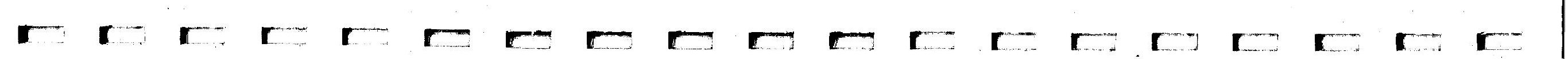




\section{EXPLORATION/EVALUATION SEQUENCE}

1. AAPG GRADIENT MAP

2. GEOTHERMAL GRADIENTS FROM EXISTING WELLS

3. GEOCHEMICAL GEOTHERMOMETRY

4. GEOPHYSICAL SURVEYING

5. DRILL SHALLOW GRADIENT/HEAT FLOW HOLES

6. DETAILED LOCAL GEOLOGICAL/GEOPHYSICAL SURVEYS

7. DRILL A DEEP HOLE TO PROVE RESOURCE 


\section{EASTERN STATES \\ RANKED BY CURRENT EXPLORATION STATUS}

1. DEL-MAR-VA PENINSULA: CRIS-MAL SITE

2. MID-ATLANTIC COASTAL PLAIN: STUMPY POINT

3. HEW YORK: THREE HIGH-GRADIENT AREAS

4. NEW HAMPSHIRE: WHITE MTN. COMPLEX

5. PENNSYLVANIA AND OHIO: GRADIENT MAPPING

NOTE: RANKING DOES NOT INDICATE EXTENT OF RESOURCE 


\section{EASTERN STATES RANKED BY CURRENT EXPLORATION STATUS}

6. NEBRASKA: GRADIENT DRILLING

7. SOUTHEASTERN COASTAL PLAIN: GRADIENT MAPPING

8. MEST VIRGINIA: GRADIENT MAPPING

9. ARKANSAS: LIMITED GEOTHERMOMETRY

10. ILLINOIS - INDIANA: INITIAL PLANNING

NOTE: RANKING DOES NOT INDICATE EXTENT OF RESOURCE 


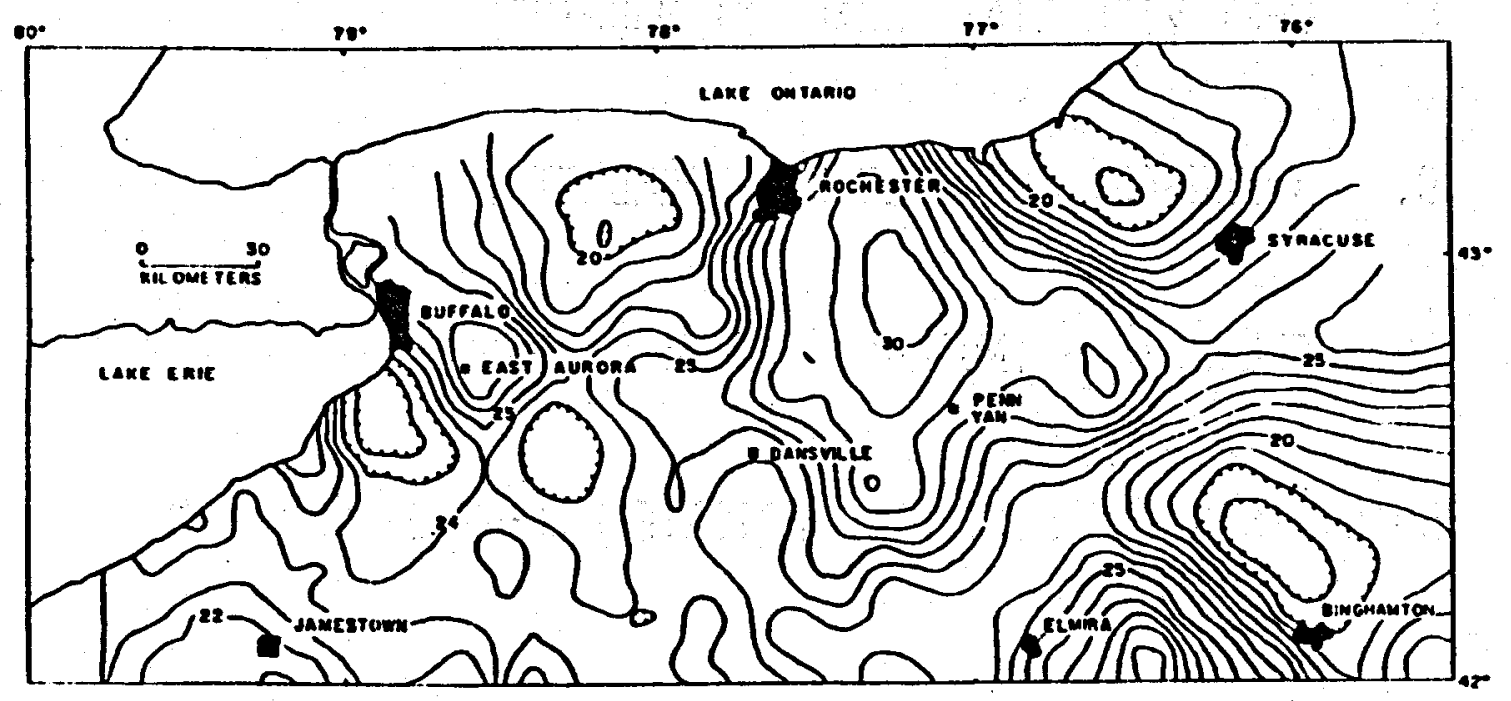




\title{
DEL-MAR-VA - CRIS-YIAL SITE
}

\author{
SHALLOW GRADIENT/HEAT FLOW HOLES \\ DEEP HOLE AT CRISFIELD AIRPORT \\ MORE SHALLOW GRADIENT HOLES
}

MORE GEOPHYSICS 


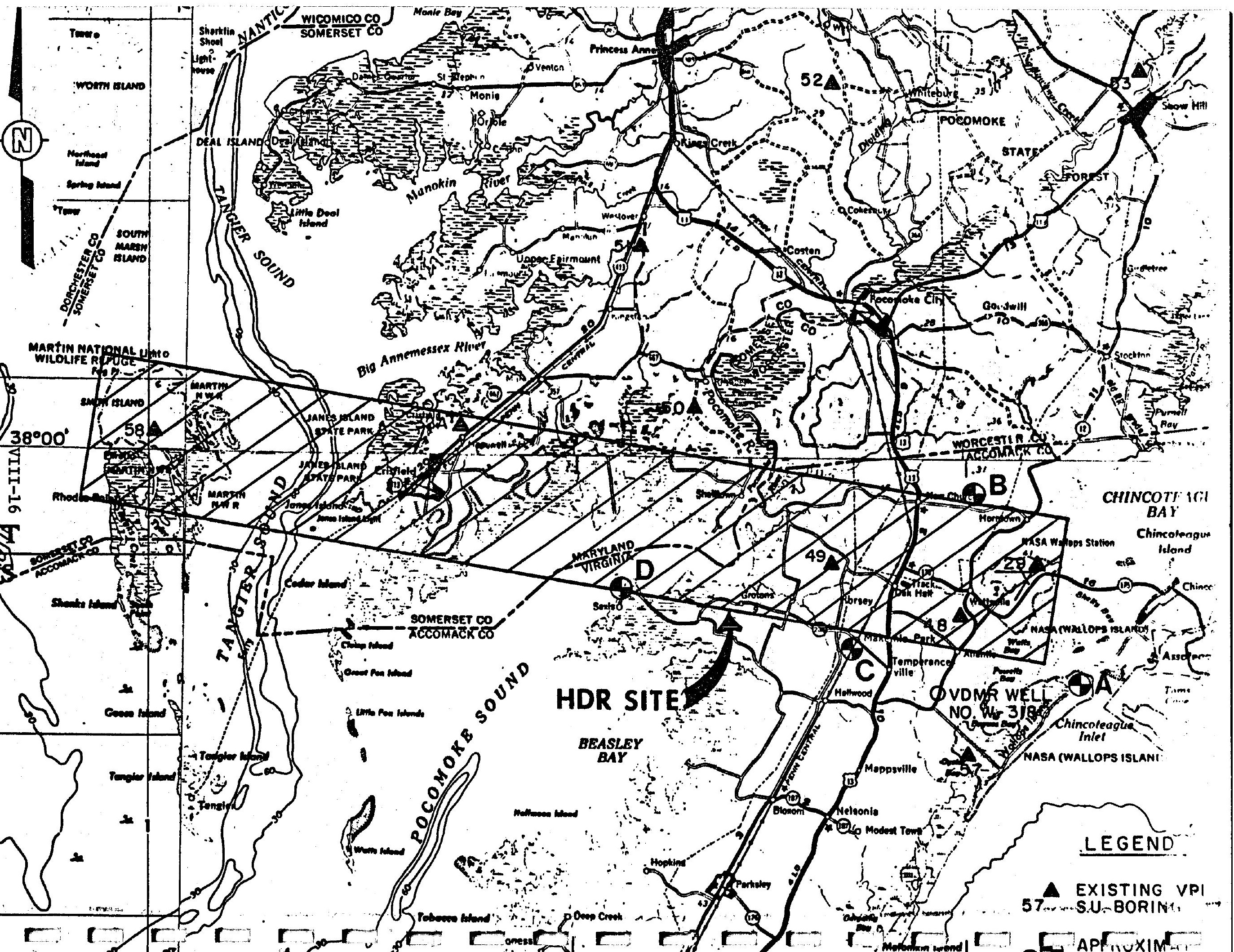




\title{
Geothermal Application Assessment
}

\author{
for the TVA Region
}

by

C. Whittle - Oak Ridge Associated

Universities, Oak Ridge, Tenn 
DRAFT WORKPLAN

GEOTHERMAL APPLICATION ASSESSMENT FOR THE TVA REGION

INSTITUTE FOR ENERGY ANALYSIS

CAK Ridge Associated Universities

\section{PROJECT GOAL}

THE PURPOSE OF THIS PROJECT IS TO ASSESS THE POTENTIAL FOR COMMERCIAL APPLICATIONS OF DIRECT GEOTHERMAL ENERGY IN A REGION OF THE UNITED StATES THAT ClOSELY CORRESPONDS TO THE TENNESSEE VALLEY AUTHORITY SERVICE AND WATERSHED REGIONS.

\section{SUMMARY OUTLINE}

I Initial Planning (September 1979 - November 1979)

II Potential Regional Geothermal Resources and Markets (Phase ONe, OCtober 1079 - September 1980)

A. Regional geothermal RESOURCE ASSESSMENT (TASK 1)

B. Potential Geothermal Energy Markets and Technologies (TASK 2)

C Summary of Findinge for Phase One Hork

III Potential Demonstration Projects and Institutional ArRangements (Phase Two, July 1980 - June 1981)

A. ADditIONAL PLANNING FOR PHASE TWO WORK

B. Identification of Potential Geothermal Demonstration PROJECTS (TASK 3)

C. Identification of Potential Institutional ArRangements (TASK 4)

IV Briefings and Final Reports (July 1981 - September 1981)

A. Presentation of Results to Various Public and

Private GRoups (TASK 5)

B. Final PROJECT RePorts 
DRAFT WORKPLAN

GEOTHERMAL APPLICATION ASSESSMENT. FOR THE TVA REGION

\author{
INSTITUTE fOR ENERGy ANALYSis \\ OAK RIDGe AsSOciated Universities
}

Initial Planning (September 1979 - November 1979)

- MEET WITH FIVE TVA gROUPS TO DISCUSS THE INITIAL DEFINITION OF THE PROJECT. THESE FIVE GROUPS ARE: NATER Systems Development, Geological Services, Energy Planning and Forecasting, Energy Demonstration and Technology, and Regional Planning.

- DEFINE TENTATIVE GEOGRAPHIC BOUNDARIES OF THE STUDY REGION, WHICH COINCIDE FAIRLY WELL WITH THE TVA REGION, TO FORM A RECTANGLE BOUNDED ROUGHLY BY $33^{\circ}$ AND $38^{\circ}$ NORTH LATITUDES AND BY $83^{\circ}$ AND $90^{\circ}$. WEST LONGITUDES.

- review activities at APL, VPI, and PuRdue University THROUGH APPROPRIATE VISITS AND REVIEW OF JOURNAL ARTICLES AND QUARTERLY REPORTS FROM EACH OF THE INSTITUTIONS.

- DRAW UP a WORKPLAN AND haVE IT REVIEWEd bY STAFF FROM OAK Ridge National Laboratory, Tennessee Valley Authority, and Department of Energy,

- REVIEW WORK by DOUg SMITH, UNiversity OF FLORIDA, ON "Geothermal Measurements in the Southern Appalachian Mountains and Southeastern Coastal Plains."

- REVIEW STATUS AND RELATED DATA FROM TVA'S CURRENT AQUIFER THERMAL ENERGY STORAGE PROJECTS.

- MAKE ADDITIONAL STAFF APPOINTMENTS AS REQUitRed tO CARRY OUT THE VARIOUS PARTS OF THE PROJECT. 


\section{DRAFT MORKPLAN \\ GEOTHERMAL APPLICATIONS ASSESSMENT FOR THE TVA REGION \\ INSTITUTE. FOR ENERGY ANALYSIS \\ OAK RIDGE AsSOCIATED UNIVERSities}

II Potential Regional Geothermal Resources and Markets (Phase ONe October 1979 - September 1980)

A. Regional Geothermal Resource Assessment (Task 1)

1. IDENTIFICATION OF EXISTING DATA SOURCES

2. AsSESSMENT OF THERMAL DATA FROM DEEP WELLS

3. ASSESSMENT OF THERMAL. DATA FROM GEOHYDROLOGY

4. CoRrelation OF thermal DATA WITH OTHER GEOPHYSICAL DATA

5. SELECTION OF POTENTIAL RESOURCE TARGET AREAS

B. Potential Geothermal Energy Markets and Technologies (TASK 2)

1. REVIEW OF ENERGY USE IN TVA REGION

2. REVIEW OF STUDIES ON APPLICATIONS OF LOW-GRADE HEAT

3. IDENTIFICATION OF SITING FACTORS FOR POTENTIAL USERS OF LOW-GRADE GEOTHERMAL HEAT

C. Summary of Findings for Phase One Work 


\section{DRAFT WORKPLAN}

GEOTHERMAL APPLICATIONS ASSESSMENT FOR THE TVA REGION

INSTITUTE FOR ENERGY ANALYSIS

OAK Ridge Associated Universities

III Potential Demonstration Projects and Institutional Arrangements (Phase Two July 1980 - June 1981)

A. Additional Planning for Phase Two Work

B. Identification of Potential Demonstration Projects (TASK 3)

1. Preliminary identification of demonstration sites

2. LiMITED DEMONSTRATION PROJECTS ASSESSMENT

C. Identification of Potential institutional Arrangements

IV Briefine and Final Reports (July 1981 - September 1981)

A. Presentation of Findings to Various Groups (Task 5)

B. Final Project Reports 
The Mitre Programs

in Support of Geothermal Development

by

Dan Entingh* - The Mitre Company

Vienna, Va.

*Mr. Entingh could not attend and accordingly a brief summary of the Mitre effort was presented by Mr. F. C. Paddison. 
December 6, 1979

Geothermal Projects at the MITRE Corporation

1. Planning, Analytic, and Progress Monitoring support to the Division of Geothermal Resource Management

The purpose of this project is to provide technical assistance in various areas of geothermal hydrothermal commercialization. Tasks include development of a national Geothermal Progress Monitor system and a Geothermal Project Management system, analyses of Site Specific Technology R\&D Needs and Nonelectric Hydrothermal Market Penetration, preparation of a User-Oriented Marketing Package, and provision of general analytical support to the Interagency Geothermal Coordination Council.

2. Technical Support for the Division of Geothermal Energy

The purpose of this project is to provide technical assistance to the Division of Geothermal Energy, Department of Energy. The work includes technical analyses of program plans, analysis of benefit/cost relationships of R\&D program content, and integration of various program segments (e.g., technology development, hydrothermal resources, geopressured resources, hot dry rock), assessments of program achievements, and strategy recommendations for enhancing the effectiveness of the total DGE program. Additional short-term studies are conducted as needed to address specific issues of programmatic redirection in response to changes in the objectives of the Division of Geothermal Energy (DGE).

About three-quarters of the project effort supports the DGE Planning Branch, while one-quarter supports the Hydrothermal Support Branch.

3. Development of Discounted Cash Flow Model for Evaluation of Geothermal Loan Guarantee Applications

This effort is developing an interactive computer program . that analyzes annual cash flows for geothermal production fields and/or power plants with known characteristics. This program will enable the Department of Energy to evaluate Geothermal Loan Guarantee applications. (703) 827-7016.

The Geothermal Project Leader at MITRE is Dan Entingh, 
The U. S. Geologic Survey Eastern

\title{
Geothermal Programs
}

\author{
by \\ Allen Kover - USGS - Geologic Division \\ Reston, Va.
}


The U.S. Geological Survey's Geothermal Research Program

by

Allan N. Kover

U.S. Geological Survey, Reston, VA 22092

The U.S. Geological Survey's Geothermal Research Program (GRP) is a multidisciplinary effort, which has the goal of understanding the nature, distribution, and energy potential of the nation's geothermal resources to provide reliable documented estimates of the magnitude of these resources for the use in planning a national energy policy. In addition, the program's work is applied to advancing the methodology of exploration for geothermal energy sources, to acquiring a systematic knowledge of the characteristics of natural geothermal systems that may influence their development, and to solving certain geo-environmental problems that may be associated with the extraction of geothermal energy. The program comprises geologic, geochemical, geophysical, and hydrologic studies. These studies are conducted primarily by the U.S. Geological Survey, but with a significant part of the program's funds supports outside research through extramural grants and contracts.

The program is divided into five broad categories; specific projects implement these objectives (see Figure 1).

The program as a whole is managed by Program Manager, Wendell $A$. Duffield, (Menlo Park, California), under the direction of the Chief of the Office of Geophysics, Robert I. Tilling, (Reston, Virginia). Donald E. White (Menlo Park), senior scient ist in geothermal research, is advisor to Duffield and Tilling. Duffield also directly coordinates geothermal investigations carried out in the Geologic Division; studies done in the Water Resources Division are coordinated by Frank i in $H$. olmsted (Menlo Park). Research outside the USGS is supported through extramural grants and contracts managed by Donald W. K1 ick (Reston). KIick also serves as 1 iaison between the USGS and other Federal agencies having geothermal programs, principally the Department of Energy (DOE). The GRP is organized and managed separately from the program of the USGS Conservation Division that is related to classification, evaluation, and leasing on Federal lands for geothermal development. However, much of the information produced by the GRP bears directly on Conservation Division's geothermal activities.

The USGS program is also designed to be complementary with that of the DOE Division of Geothermal Energy and is coordinated with DOE during both its planning and the implementation. The USGS studies are principally generic, placing emphasis on the entire geothermal system, including the heat source, fluid recharge zones, and the encompassing geologic and hydrologic regimes, whereas DOE's program focuses on individual reservoirs having systems that may be commercially productive (see Figure 2). The USGS program assesses geothermal resources on a broad regional basis, whereas DOE's program evaluates the energy 
potential at individual locations and stresses precommercial and industry-coupled projects at specific sites within regions defined by the Survey.

The internal work of the GRP is carried out in 72 individual projects, which are in six topical categories (see Figure 3 ). The most significant accomplishment of FY 1979 was the publication of USGS Circular 790. I This report was the culmination of a major effort to update the first national assessment of U.S. geothermal resources, which has been completed in 1975:-2 of particular interest to DOE's Eastern Region is the first tabulation of low-temperature geothermal waters (less than $90^{\circ} \mathrm{C}$ at depths less than $1 \mathrm{~km}$ ), which is included in Circular 790. Although it was not possible to accuately measure the availability of this resource, such low-temperature waters appear to be widely available over much of the country and should have significant potential for space heating and agricultural applications. The effort to better understand the availability of $20^{\circ}-150^{\circ} \mathrm{C}$ waters will be significantly increased in FY, 1980. This work will be materially assisted by further use of GEOTHERM ${ }^{3}$, the computerized geothermal data file established several years ago within the USGS.

Although all the geothermal energy produced to date has been from hydrothermal systems in permeable rock, two other types of geothermal environments may represent even larger potential sources of energy-geopressured zones and hot dry rocks (HDR). Research involving HDR is conducted in several topical categories (see Figure 3). In FY 1979 and FY 1980, the GRP has intensified its effort in understanding the resource potential of these environments. A bibliography of all USGS geothermal reports and publications is available from the GRP. Most of the work done to date has been in the west, but some reports include DOE's Eastern Region or investigations that have general rather than specific regional significance. In addition, the USGS GRP extramural program supports a project in North Carolina to study trends in metamorphism, plutonism, and heat flow under the Atlantic Coastal Plain. Principal Investigators are Lynn Glover III, John Costain, and A. Krishna Sinha and associates at the Virginia Polytechnic Institute and State University, Blacksburg, Virginia. The objectives of projects are to obtain knowledge of basement geology under the Atlant ic Coastal Plain so as to improve ability to target radiogenic granites as potential geothermal heat sources. To date, investigators have completed two holes, a new one in the Fountain belt and a deepened one in the Hatteras belt, and are now studying the cores. This project is closely coordinated with related work supported by DOE's Division of Geothermal Energy.

1/Muffler, L. J. P., ed., 1979, Assessment of Geothermal Resources of the Uniteg States--1978: U.S. Geol. Survey Circular 790, 163 p., 3 maps.

2/ White, D. E., and Williams, D. L., eds., 1975, Assessment of Geothermal Resources of the United States--1975: U.S. Geological Survey Circular 726, 155

I/Swanson, J.R., 1977, Geotherm User Guide: US Geol. Survey open-file rept. $77-504,53 \mathrm{p}$. 
U. S, GEOLOGICAL SURVEY GEOTHERMAL. RESEARCH PROGRAM

1. NATIONAL AND REGIONAL RESOURCE INVENTORY

2. EXPLORATION AND ASSESSIMENT TECHNOLOGY

3. RESOURCE CHARACTERIZATION

4. GEOLOGIC CONTROLS OF SUBSURFACE POROSITY AND PERMEABILITY

5. GEOENVIRONMENTAL EFFECTS OF GEOTHERMAL PRODUCTION 


\section{FLOH CHART - $\Lambda$ CASE STUDY}
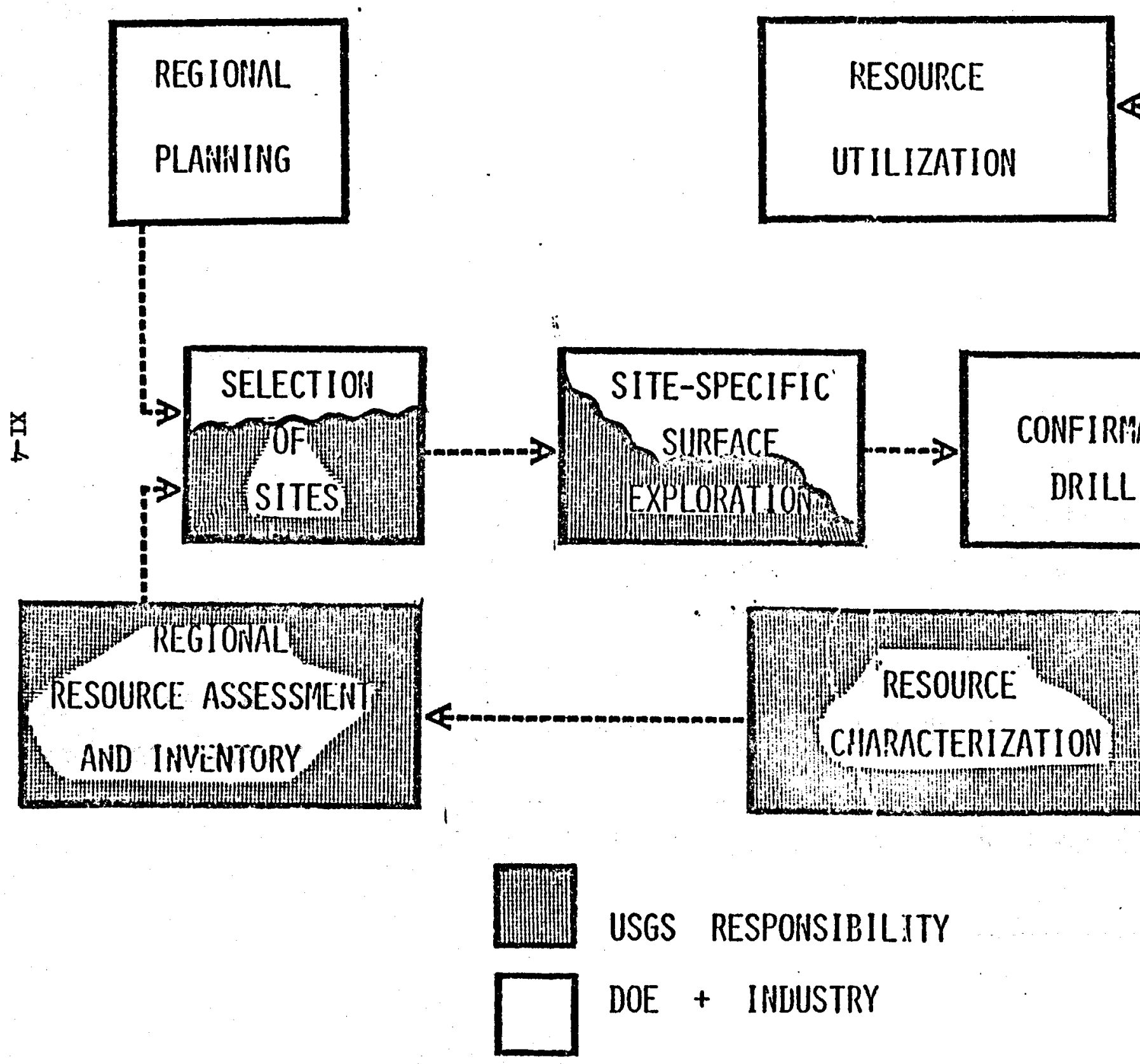

USGS RESPONSIBILITY

FIGURE 2

DOE + INDUSTRY

CONFIRRATION DRILLING

RESERVOIR

ENGINEERING 


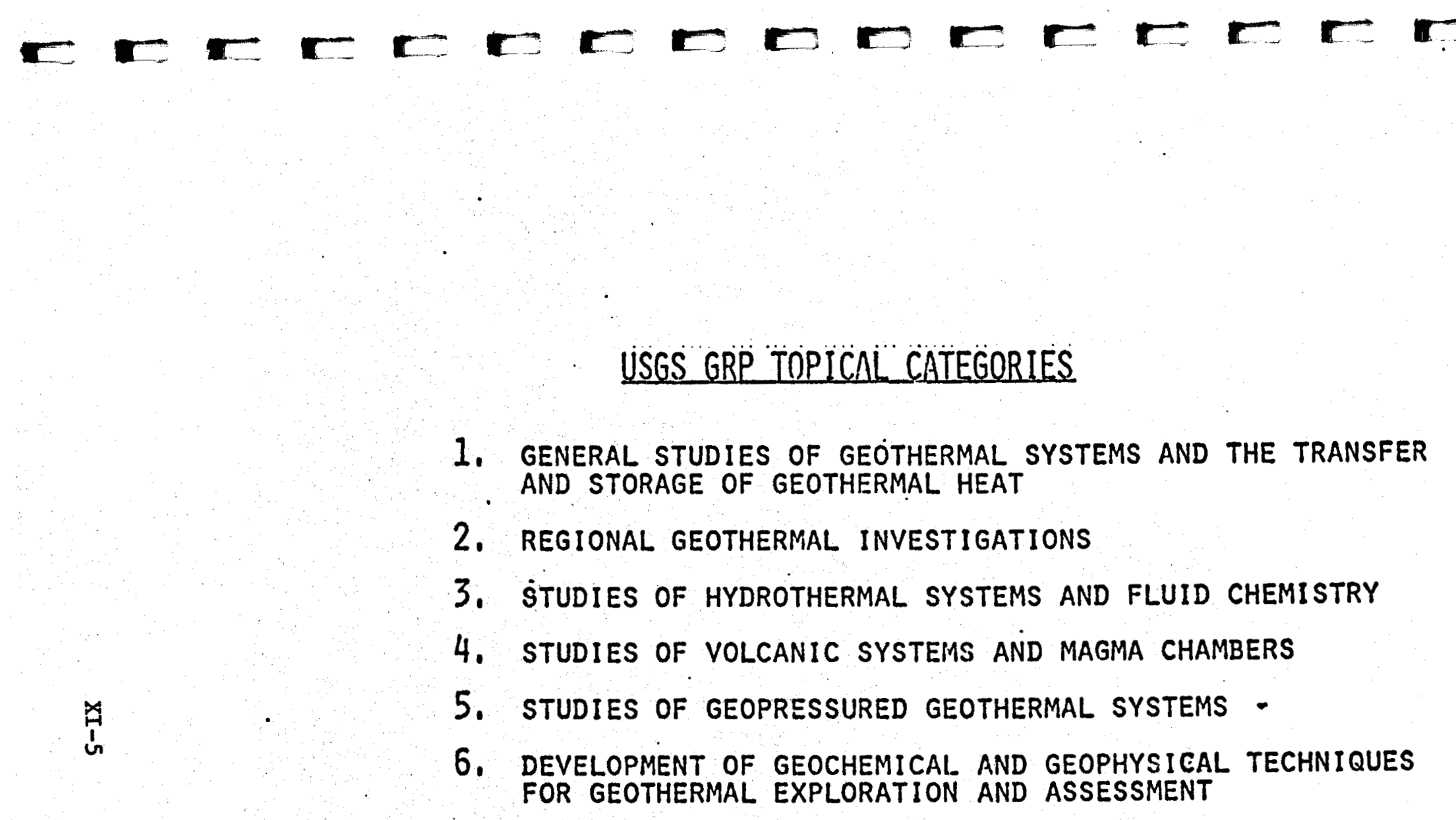

USGS GRP TOPICAL CATEGORIES

1. GENERAL STUDIES OF GEOTHERMAL SYSTEMS AND THE TRANSFER

2. REGIONAL GEOTHERMAL INVESTIGATIONS

3. STUDIES OF HYDROTHERMAL SYSTEMS AND FLUID CHEMISTRY

4. STUDIES OF VOLCANIC SYSTEMS AND MAGMA CHAMBERS

6. DEVELOPMENT OF GEOCHEMICAL AND GEOPHYSICAL TECHNIQUES FOR GEOTHERMAL EXPLORATION AND ASSESSMENT 
The Crisfield Well, Somerset County, Maryland

\section{by}

\section{Kenneth A. Schwarz}

Md. Geologic Survey,

Baltimore, Md. 
THE CRISFIELD WELL

SOMERSET COUNTY, MARYLAND

by

Kenneth A. Schwarz

Maryland Geological Survey.

Johns Hopkins University

Baltimore, Maryland 21218

Eastern Geothermal Technical Information Interchage Meeting Berkeley Springs, West Virginia - October 30/31, 1979

XII-1 
In the next few minutes $I$ will cover three points. First, $I$ will discuss the State of Maryland's involvement with the drilling of the Crisfield Well, which may typify the situation that you might expect from other states if you were to drill a geothermal well in their jurisdiction. Secondly, I will review briefly the geologic setting as we knew it before the Crisfield Well was drilled, and last of all, I'll discuss the Crisfield Well itself.

The Maryland Geological Survey (MGS) is a part of the Department of Natural Resources (DNR) and is concerned with data acquisition for learning more about the fresh water aquifers as well as the deeper subsurface reservoirs. We have a long-standing cooperative program with the U.S. Geological Survey similar to that pointed out this morning by Gordon Bennett in his paper. This program has developed a good hydrogeologic data base on prospective aquifers including a functional digital simulation model whereby we can predict the effects of continued water usage in the future.

The Survey was a liaison between state agencies and the Department of Energy. We tried to anticipate problems before they appeared. If Jerry Brophy called to tell of a conflict, we'd get on the phone to try to iron things out on a timely or mutually agreeable basis. In a sense we acted as DOE's "hit man" against the state bureaucracy.

The Water Resources Adminiștration (WRA) of DNR issued drilling permit which helps protect the citizens from incompetent or unscrupulous operators -- and there have been operators as that in the past. The WRA also issues discharge permits which help to protect the environment from the dumping of hazardous or incompatible wastes. As an example, the WRA was prepared to issue a temporary discharge permit for dumping the deep produced saline waters into the Chesapeake Bay during production tests, if it were necessary to do so. 
What was known about the geology before the Crisfield Well? The first overhead cartoon $I$ have is an east-west cross section of the Atlantic Coastal plain at no particular scale. Washington and Baltimore are on your left, Chesapeake Bay in the middle, Ocean City is at the shoreline of the Atlantic ocean at your right. Basement rock outcrops from the fall line at Baltimore and westward. The sedimentary wedge thickens eastward as previously pointed out by the speakers from Virginia Polytechnic Institute. The Coastal plain is a proved groundwater province in which the Cretaceous Potomac Group is an important aquifer. Three deep wells were drilled by oil companies in the 1940's. The one at Ocean City was drilled to 7700 feet, had an anomalously high bottom hole temperature, and did not encounter any basement rock. The other two wells both tagged basement, but to our knowledge, never recorded bottom hole temperatures. The Janes Island State Park well, only one mile from the Crisfield drillsite, was drilled to 1500 feet and tested fresh water as deep as 1200 feet. The state park well has an anomolous brackish water interval overlying the fresh water strata. And, of course, Chesapeake Bay is a brackish body of water.

In this geologic setting then, why was the Crisfield Well chosen? VPI has previously given you the details of the seismic, the gravity, the aeromagnetics and the 1000 feet heat flow wells, thirteen of which were drilled in Maryland, indicating the crisfield site to be very favorable from a number of disciplines.

The initial draft for the well indicated a 5000 feet depth or a basement test, whichever is shallower, for the Low to Moderate Temperature Program, which then would be deepened about 700 feet for the Hot Dry Rock Program.

What did this well tell us? The second cartoon I have shows a diagram of the Crisfield Airport Well. It began drilling in May 1979. Casing was 
set near 200 feet as well as at 1700 feet, where $\operatorname{logs}$ wore run at the insistance of the MGS in order to determine the base of the fresh water, which was encountered about 1600 feet. Drilling continued uneventfully with normal mud weights through alternating sands and shales of Cretaceous and possibly older age clastics. The top of basement was penetrated at 4455 feet $E-\log$ measurement, and was defined as the first zone of essentially zero percent porosity as indicated on the porosity logs. Casing was set at 4600 feet and the well deepened more than 900 feet for the Hot Dry Rock Program. It was then logged, fractured and relogged. The sands encountered from 2700 to 4200 feet all were deemed suitable for deep production or shallow reinjection, if necessary. Three deep sands, in particular, shown by the squares on the borehole yielded sufficient volume and temperature for limited application of this resource. The testing of the hole will be the subject of subsequent talks.

The rig was released in August 1979, the hole permanently abandoned in september 1979. At present the operator is cleaning the site, since the plastic liners for the mud pits, which were buried by bulldozers, have been exhumed by the recent rains. Also, the road to the airport is being resurfaced, since it was broken up by heavy truck traffic during drilling operations.

This concludes my report. Thank you.

KAS : chm attachments 


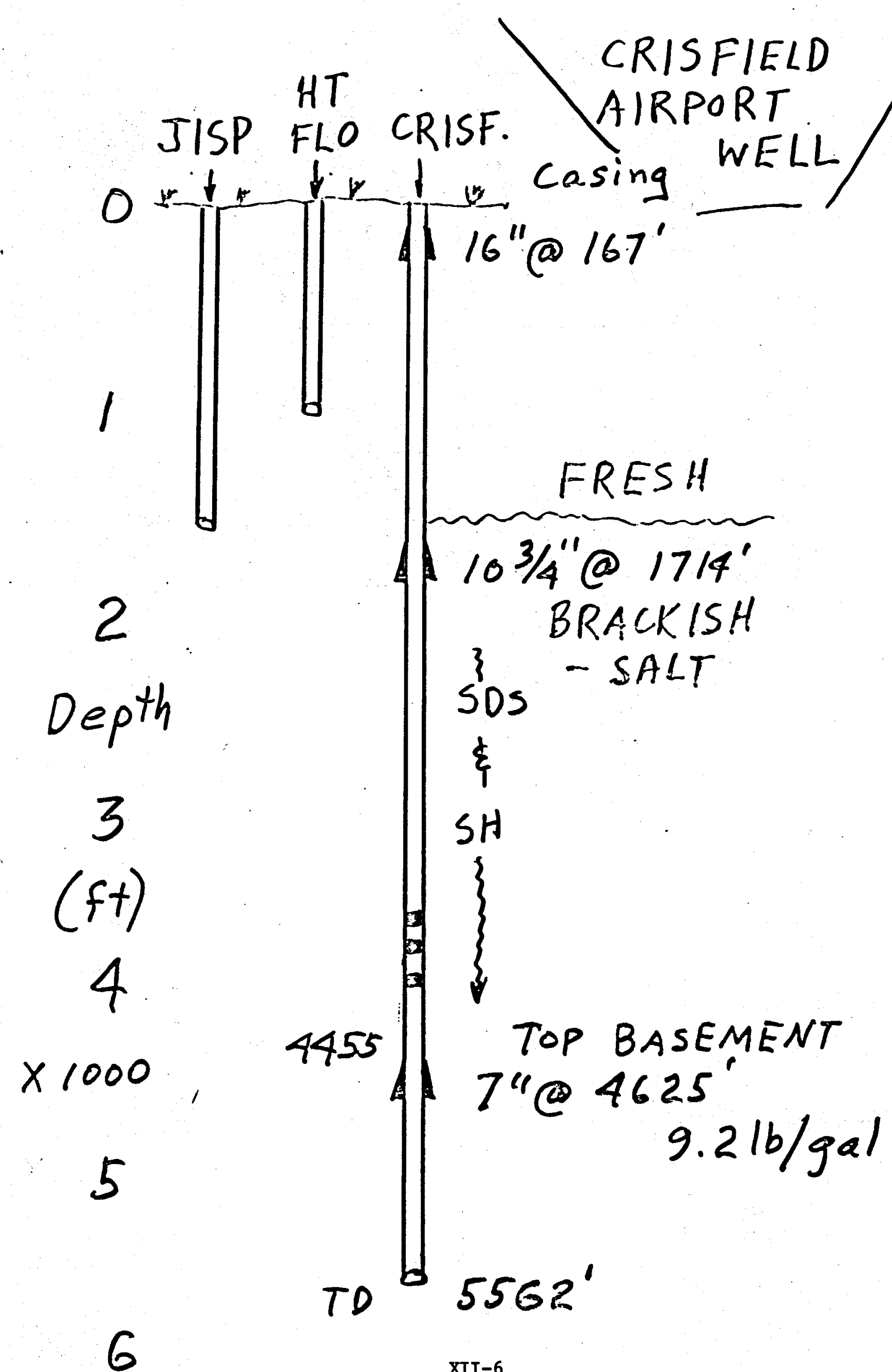


Analysis of Test Data From

DOE Crisfield Airport Well No. I

by

Dr. James H. Hartsock*

Gruy Federal

2500 Tanglewilde Suite 150

Houston, Texas

\section{XIII}

*Dr. Hartsock could not attend meeting but forwarded this summary for inclusion in the minutes. 
ANALYSIS OF TEST DATA FROM

DOE CRISFIELD AIRPORT NO. 1 WELL

The Department of Energy Crisfield Airport No. 1 Well was the first deep well drilled to evaluate the geothermal potential of the Cretaceous sediments in the Atlantic Coastal Plain Geothermal program. The test well was located on property adjacent to the runways at the Crisfield Municipal Airport in Somerset County, Maryland.

The well was spudded on May 13, 1979 and drflled and cored to a total depth of 5662 feet. Listed below is a tabulation of the casing and cementing program:

HOLE

Size, Size, Weight, CASING

in. In. $1 \mathrm{~b} / \mathrm{ft}$ Grade Conn. at

$20 \quad 16 \quad 65.0 \quad$ H40 ST\&C 165

$\begin{array}{lllll}14-3 / 4 & 10-3 / 4 & 40.5 & \text { J55 ST\& } 1714\end{array}$

$$
9-7 / 8 \quad 7-5 / 826.4 \quad \mathrm{~K} 55 \quad \text { ST\&C } 4625
$$

\begin{tabular}{|c|c|c|c|}
\hline $\begin{array}{l}\text { Amt. } \\
\text { (sx) }\end{array}$ & Type & $\begin{array}{l}\text { Wt.' } \\
1 \mathrm{~b} / \mathrm{gal}\end{array}$ & Remarks \\
\hline 150 & HLW & 12.7 & $2 \% \mathrm{CaCl}_{2}$ cmt. circ. \\
\hline 500 & HLW & 12.7 & $2 \% \mathrm{CaCl}_{2}+3 / 4 \% \mathrm{CFR} 2$ \\
\hline 500 & A & 15.6 & $\begin{array}{l}2 \% \mathrm{CaCl}_{2}+3 / 4 \% \mathrm{CFR} 2 \\
\text { circ. approx. } 250 \mathrm{sx}\end{array}$ \\
\hline 500 & HLW & 12.7 & $2 \% \mathrm{CaCl}_{2}+3 / 4 \% \mathrm{CFR} 2$ \\
\hline 500 & HLW & 12.7 & $3 / 4 \%$ CFR2 \\
\hline 500 & A & 15.6 & $3 / 4 \%$ CFR2 \\
\hline
\end{tabular}

During drilling a total of 13 cores were attempted at various intervals throughout the section. A total of 331 feet was cored with an overall recovery rate of 64 percent.

After the 7 5/8-inch casing string had been run and cemented at 4625 feet, operatIon of the well was assumed by the engineering staff with the Hot Dry Rocks Geothermal program from the Los Alamos Laboratory. They drilled and cored to the total depth and conducted a small volume hydraulic fracturing experiment, after which the open hole was squeeze cemented and plugged. 
The original well testing prognosis was designed to short-term test up to three aquifers at a pumping rate of 5000 barrels per day followed by a 30day test of the most productive aquifer. The long term test was eventually cancelled because of the cost required to drill a disposal well.

For testing purposes the well was equipped with a 17-stage Reda centrifugal pump with a 60 horsepower motor capable of delivering 5000 barrels per day (146 gpm) against a fluid head of 600 feet. The surface equipment included a water meter, a sonic sand detector; a scale coupon, a temperature recorder, a calibration tank and a screen filter. Bottom hole pressures were recorded with a surface recording Hewlett Packard quartz crystal gauge capable of measuring pressures to within $\pm .01 \mathrm{psi}$.

The well penetrated several sand members below 3800 feet whose thicknesses varled from 6 feet to 46 feet. Three zones were selected for testing; however, two of the zones were incapable of sustaining rates of 5000 barrels per day. A smaller pump was installed to test these zones, but the pressure data were anamolous owing to mechanical problems within the pump and tubing string. The accompanying table summarizes the results of the testing program. The maximum recorded surface temperature during pumping operations was $127^{\circ} \mathrm{F}\left(52.8^{\circ} \mathrm{C}\right)$. 
Summary of Test Results from DOE/Crisfield We11

$\begin{array}{lccc} & \text { Zone 1 } & \text { Zone 2 } & \text { Zone 3 } \\ \text { Gross interval } & 4148^{\prime}-4223^{\prime} & 3901^{\prime}-4032^{\prime} & 3798^{\prime}-3846^{\prime} \\ \text { Net sand thickness } & 62^{\prime} & 86^{\prime} & 4^{\prime} \\ \text { Average porosity } & 174^{\prime} & 24 \%^{\prime} & 29 \%^{\prime} \\ \text { Effective permeability } & ? & 75 \text { mds } & ? \\ \text { Density (gm/cc) } & 1.040 & 1.032 & 1.036 \\ \text { Total dissolved solids (ppm) } & 71,793 & 71,511 & 72,039 \\ \text { pH } & 6.36 & 6.52 & 6.69 \\ \text { Ca }+\mathrm{Mg} \text { Carbonates (ppm) } & 20,155 & 12,707 & 16,621\end{array}$


Crisfield, Maryland Well Characteristics

Determined Using All Test Data

by

K. Yu

Applied Physics Laboratory

The Johns Hopkins University 
In this paper we present the results of the analysis performed at the Applied Physics Laboratory on the well-test data obtained at the DOE Crisfield test well.

The well test was conducted in three parts, one each for the three "test zones" shown on Table 1 . Some of the $10 \mathrm{~g}$-inferred data and the salinities of the waters taken from these zones are shown in the second Table.

After a brief review of the entire test data sequence the second zone data was selected for anlaysis for two main reasons. First, this zone was the most productive of the three. Secondly, the data were most complete as well as being more reliable than the other two.

The development of the second zone was initiated at 2:16 a.m. on June 27. The "development" conslsted of several Irregular sequence of pumping and stopping at various pumping rates, typical of oil-well development. The final segment of "developmental" pumping was initiated at 06:00 and continued for one and a half hour at pumping rates of 116 to 82 GPM. The well was then allowed to recover t1ll 11:03 (June 27) when the "pump-test" phase was inftlated.

The "pumping phase" continued t111 11:00 a.m. on June 29, followed by a 48-hour recovery period. Throughout the pumping phase, the pumping rate changed considerably including a, 23-minute shut down (caused by an equipment malfunction) commencing at 00:07 on June 29, 1979.

Aside from the numerous perturbations in the pumping rate, both the "development" and the "pumping" phases (particularly the earlier parts) were plagued with considerable sand production. The pressure-time history is shown in Figures 1 and 2 .

Before proceeding further, several features merit some comments. First, the pressure drop occuring at 07:55 does not involve pumping head loss. Although there is no notation in the pump-test record, it was inferred that this pressure drop was caused by the pressure sensor being pulled up from the Initial depth of $3966.5 \mathrm{ft}$ (1isted at the beginning of the pump test record) to 1ts final depth of $3890 \mathrm{ft}$ (stated 


\section{Table 1}

CRISFIELD GEOTHERMAL TEST WELL

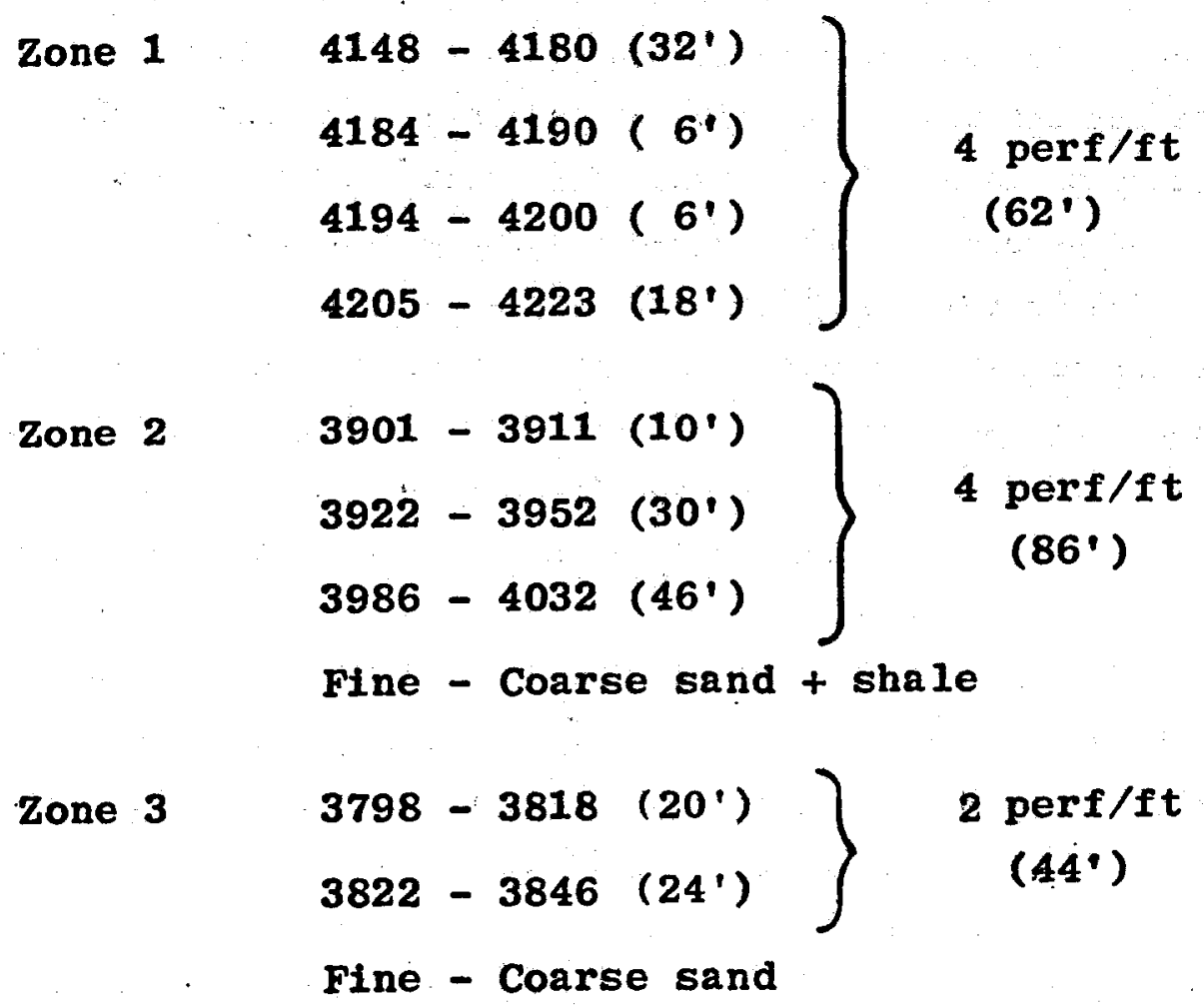


CRISFIELD TEST WELL

LOG INFERRED DATA

\begin{tabular}{|c|c|c|c|c|}
\hline ZONE & $\begin{array}{l}\text { EFFECTIVE } \\
\text { POROSITY }\end{array}$ & $\begin{array}{l}\text { SHALE } \\
\text { FRAC }\end{array}$ & $\begin{array}{c}\text { NET } \\
\text { THICKNESS } \\
\end{array}$ & SALINITY \\
\hline 1 & .17 & .29 & 57 & 65.51 \\
\hline 2 & .24 & .16 & 87 & 46.83 \\
\hline 3 & $\begin{array}{r}29 \\
\end{array}$ & .19 & 44 & 46.83 \\
\hline
\end{tabular}


end of the record). The least square fit parameters to the pressure sensor cal1bration measurement performed at the end of test (13:40 to 15:00, July 1, 1979), give an apparent pressure drop of 34.28 psi for this depth change. This is quite consistent with the initial static pressure of $1766.02 \mathrm{ps}$ and the Horner-plot inferred terminal pressure of $1732 \mathrm{psi}$. The supposition that the pressure sensor was, pulled up by $76.5 \mathrm{ft}$ is further supported by the fact that, with the associated pressure correction, the apparent drop in the pressure disappears and the corrected test data gives rise to a continuous derivative of the pressure recovery data.

The second feature is that at the time when the "pump-test" phase has commenced, the pressure head was actively recovering. As will be discussed further below this introduces transients in the early part of the data.

The third feature is the presence of numerous perturbations throughout. The three little "gliches" seen in Figure 2 are due to the throttling down operations during the turbine meter calibration. The break in the curve covers the period of 23-minute-shut-down, and the 30-minute segment following the shut-down, during which the electronics malfunctioned.

The calibration measurements of the turbine meter were performed three times during pumping. The results indicate that the turbine meter readings are stable, but approximately $10 \%$ less than the true pumping rate.

Applicability of The Conventional Evaluation Methods

Customarily three methods are available for the analysis/ evaluation of an unsteady (i.e., non-steady state) flow. These methods are all based upon the assumption of a constant pumping rate and the total absence of any other extraneous transients.

To determine the presence of leakage and/or delayed yield it is useful to examine the so-called Theis plot, 1.e., the log-log. plot of the drawdown vs. the pumping time.

For the pressure loss we may reference the static level* of

\footnotetext{
* See the discussion in the previous section (re: raising of the pressure sensor)
} 
1732 psi. For the time axis, however, as the pumping was initiated while the head was actively recovering, there is no convenient reference point avallable. We have therefore used the actual pumping time in Figure 3 which are the plots of representative data points. It is seen that the curvature is minimal, eliminating the possiblity of a rellable determination of the transmissivity and the storage coefficient by matching it with the theoretical Theis curve. With the assumption that the changes in the pumping rate can be neglected, Figure 3 shows that there is no evidence of recharge into the second zone for the duration of the pump test. By the same token we see no evidence of leakage (or delayed yleld) for this zone. In view of the well-1og we conclude that this zone may be treated as a confined aquifer. Thus, aside from this qualitative indication, the Thels curve method fails to provide a reliable estimate of the formation parameters.

The second method is to examine the pumping time in semi-log plot against the drawdown (FIgure 4). This involves the same difficulty of not having a true time reference as in the previous case. In any event, It Is seen that the curve does bend at about $6 \mathrm{th}$ minute of pumping. According to an elementary (text book) theory this ts supposed to be a straight line (provided the pumping rate has been held constant). As the pressure was actively recovering when the pump-test phase was inftiated, the early part of the data cannot be separated from the pre-existing transient effects. (Further, it is not known if all of the perforation holes were producing at the beginning). After the bend (1.e., post 6th minute), we estimate the apparent transmissivity to be approximately $.70 \mathrm{~cm}^{2} / \mathrm{sec}(\approx 487 \mathrm{GPD} / \mathrm{ft}$, in hydrologist's units). In view of the multitudes of pumping rate variations, together with the pre-existing unrecovered drawdown condition, however, this value is shrouded in uncertainty. Further, the time reference uncertainty eliminates the possibility of inferring the storage coefficient. 
To avoid the "noise" problem often seen in the pumping phase data often the ratio of "the time since the pumping started" to "the time since the recovery started" is studied a semi-log plot against the pressure (head) recovery (the Horner plot). This, too, is supposed to yield a straight line according to the elementary theory. In Figure 5, we present the Horner plot of the recovery data. It is seen that the curve bends very noticeably. This is due to the transient effects and the "real well" effects which we will discuss further in the next section. Due to these factors, the Horner plot will yield an unreliable result.

Thus, the conventional methods ${ }^{*}$ of data analysis are not applicable to the data on hand (the second zone data). Theoretical Calculations

We have established that Zone 2 has behaved as a confined aquifer during the pump test. Since there were no observation wells there is no ground to Introduce any anisotropy. We have therefore chosen the model to be an isotropic and homogeous confined aquifer. We have further assumed that the aquifer parameters remained constant throughout ${ }^{*}$ *

The head-loss calculations were made, using all 85 variations in the pumping rate, for a fixed set of permeability and storage coefficient. The approximate ranges covered are $10 \mathrm{~cm}^{2} / \mathrm{sec}$ to $10^{-3} \mathrm{~cm}^{2} / \mathrm{sec}$ for the transmissivity (corresponds to approximatley 2 darcys down to 0.2 millidarcy) and 10 to $10^{-5}$ for the storage coefficient. Calculations were repeated to minimize the difference between the experimental data (where avallable) and the theoretical headloss during the pumping phase.

Best fit to the pumping data was obtained for the teransmissivity of $.50 \mathrm{~cm}^{2} / \mathrm{sec}$ (near 107 millidarcys), with an effective storagecoefficient* of 0.20 . Theoretical results are shown in Figures 6 and 7 .

*

At times, some analysts plot the recover time vs the pressure on a semi-1og paper, and, from its slope, attempt to determine the transmissivity. This is actually on an even shakier theoretical ground and should not be taken serious 1 y.'

**

There was considerable sand production, particularly during the early times. This will Introduce a time variation of the effective storage coefficient. But the use of this assumption leads to an independent estimate of the radius extension effect.

*** For the calculation, the well radius was taken to be equal to the casing radius, $1 . e ., 12.54 \mathrm{~cm}$. 
Comparison of Figs. 1 and 6 shows the large sand production effect. More interesting comparison is that between F1gs. 2 and 7 . We note that the agreement isyfor the most part, better than \pm 1 to 2 psi (during the pumpIng phase). Comparison of the recovery phase, however, show that the experimental data logging the theoretical well recovery during the early hours. This difference of approximately 10 psi can be explained on the basis of the real well effect.

Unlike the "mathematical" well which is infinitely thin, the real well has a finite radius, within which the water content is $100 \%$ as opposed to porocity on $25 \%$ in the theoretical case. Th1s gives rise to an integral equation, for which we have obtained an approximate first order perturbation solution. Evaluating the first order correction in the appropriate range we get some $10 \mathrm{psi} \mathrm{lag}^{*}$ in the recovery, which eliminates the apparent disagreementof the theoretical calculations with the recovery data.

\section{Storage Coefficient}

Customarily the effective storage coefficient of 0.20 is a good Indicator of a water-table type of open aquifer. Since the aquifer is confined (so far as tested), In this case, it provides a measure of the sand production/radius extension effects.

Since the Zone 2 sand formation is known to be "fine-coarse sand + shale" we take it to be equivalent to the looser end of the "dense sand," for which the bulk modules $1 \mathrm{~s} 1.0 \times 10^{6} \mathrm{lb} / \mathrm{sq} \mathrm{ft}$. For the water at $131^{\circ} \mathrm{F}$, the isothermal compressibility is $4.44 \times 10^{-11}$ dynes $/ \mathrm{cm}^{2}$. (Chem. Rubber Hdbk 42nd Ed. p. 2161). From this, we obtain the storage coefficient to be $3.9 \times 10^{-3}$. Sand Production Effect (Radius Extension Effect)

The argument of the so-called well function (the exponential Integral of order 1) contains a factor $r^{2} s$. What this means is that

$$
\frac{r_{\text {true }}}{r_{\text {calc }}}=\frac{S_{\text {eff }}}{S_{\text {true }}} \sim 7
$$

as the measure of sand production.

* The first order correction term is proportional to $\mathrm{T}^{-2}$. Thus the real well effect is more pronounced for a well with low transmisivity such as the one under consideration. This causes a noticable bend in the Horner plot. *See W. C. Walton, Groundwater Resource Evaluation, McGraw-H111 (1970), p. 627, Table 9.2. 
PARAMETERS

Transmissivity: $.50 \mathrm{~cm}^{2} / \mathrm{sec}$

$\underset{\infty}{\hookrightarrow}$

Effective storage coff: $\quad .20$

$$
\begin{aligned}
& u=\frac{R_{w}^{2} S}{4 T t} \\
& R_{e f f}^{2} S-R_{w}^{2} s_{e f f}
\end{aligned}
$$


CONCLUSIONS

- Aquifer (Second Zone) - Limited, but useable

- Aquifer Parameters (Best fit of all test data)

Temp: $130-135^{\circ} \mathrm{F}$

Permeability: $110 \mathrm{md}$

(Transmissivity: $.50 \mathrm{~cm}^{2} / \mathrm{sec}$ )

Storage Coefficient $3.9 \times 10^{-3}$

- $R_{e f f} / R_{w} \approx 7$ 


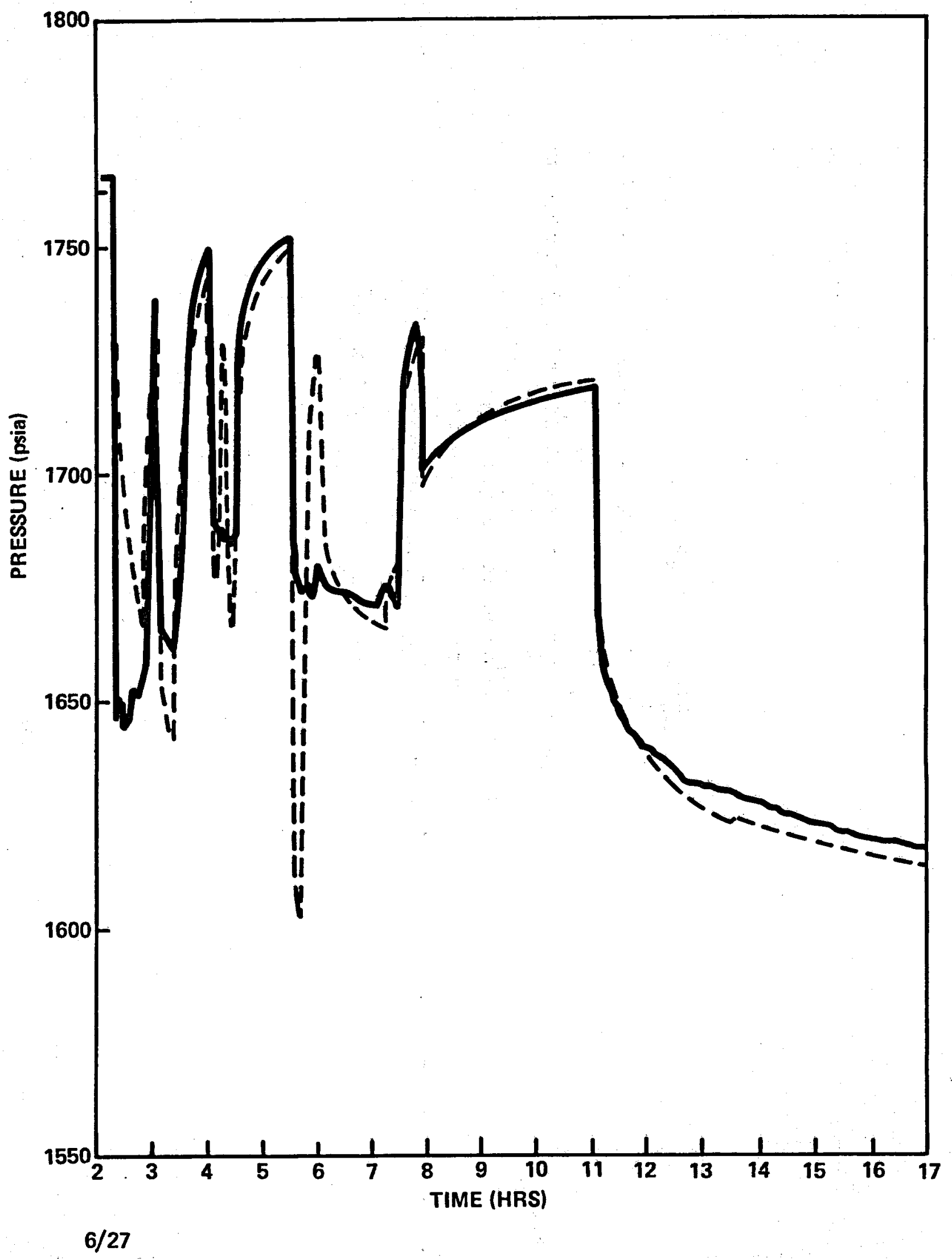

$$
\text { XIV-10 }
$$




\section{CRISFIELD WELL, ZONE \# 2 TEST}

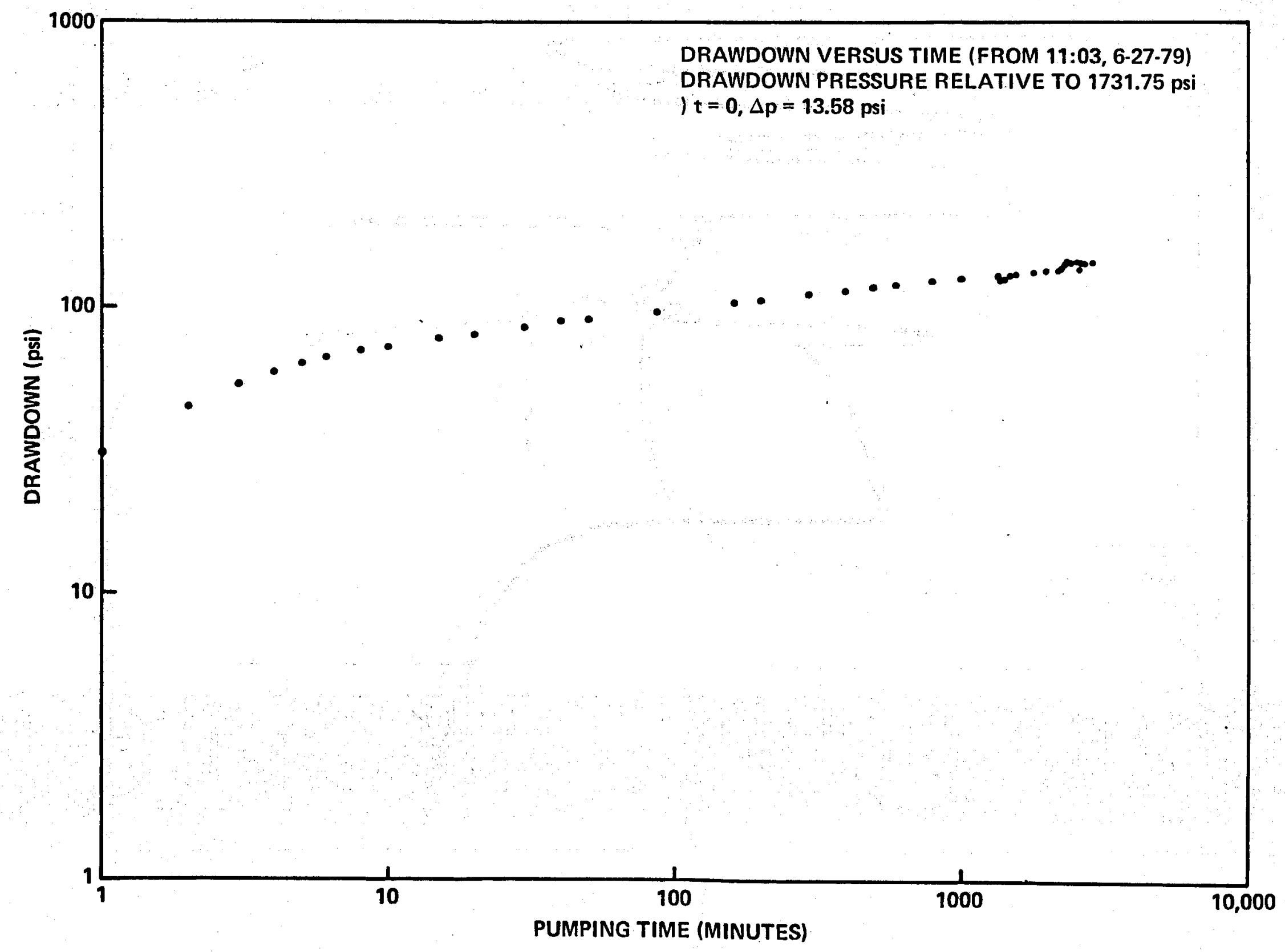

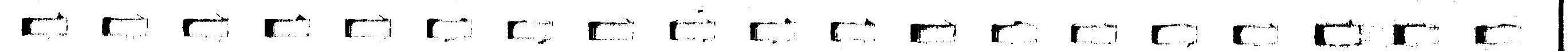



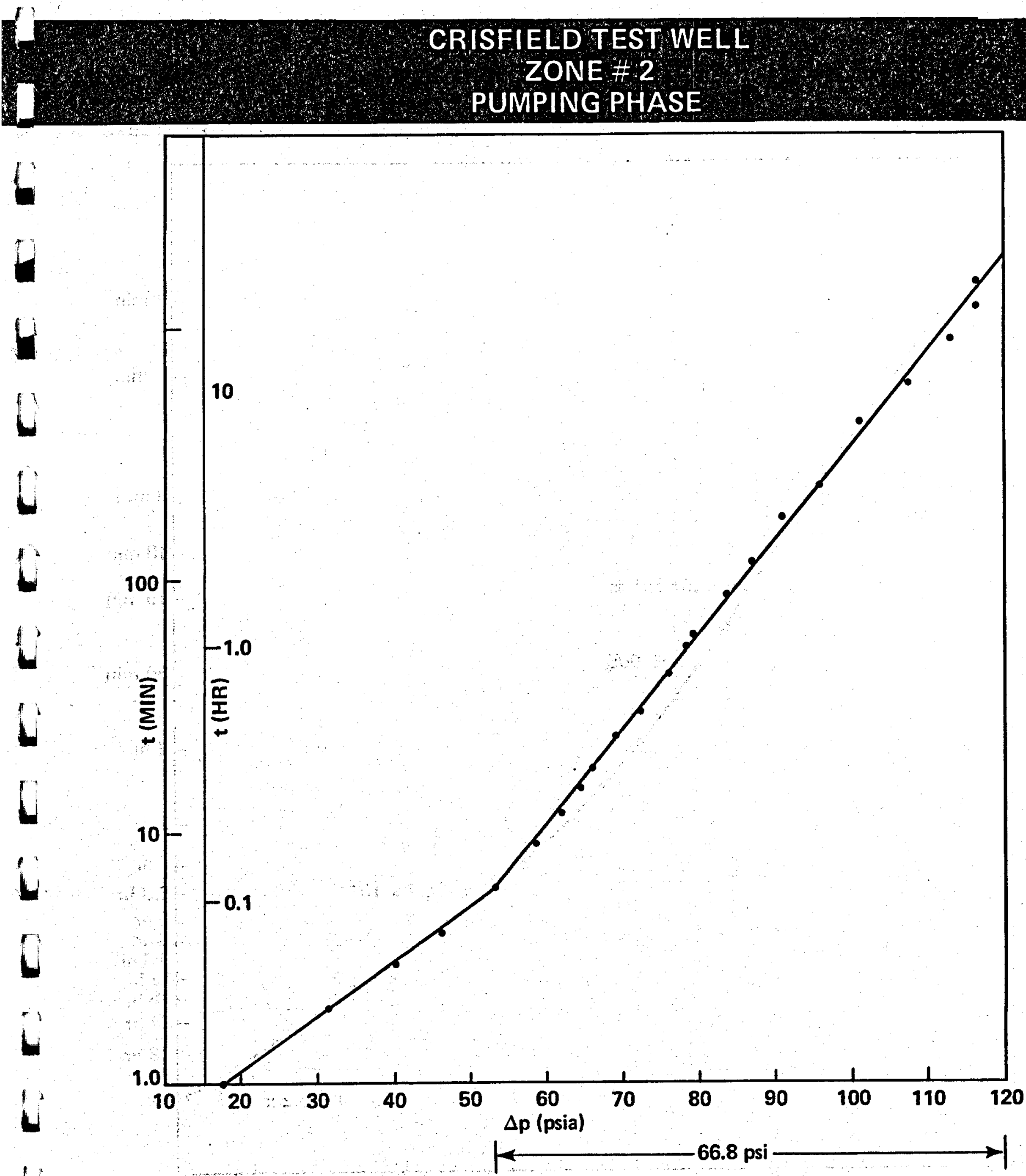


\section{CRISFIELD TEST WELL ZONE \# 2 \\ RECOVERY PHASE}

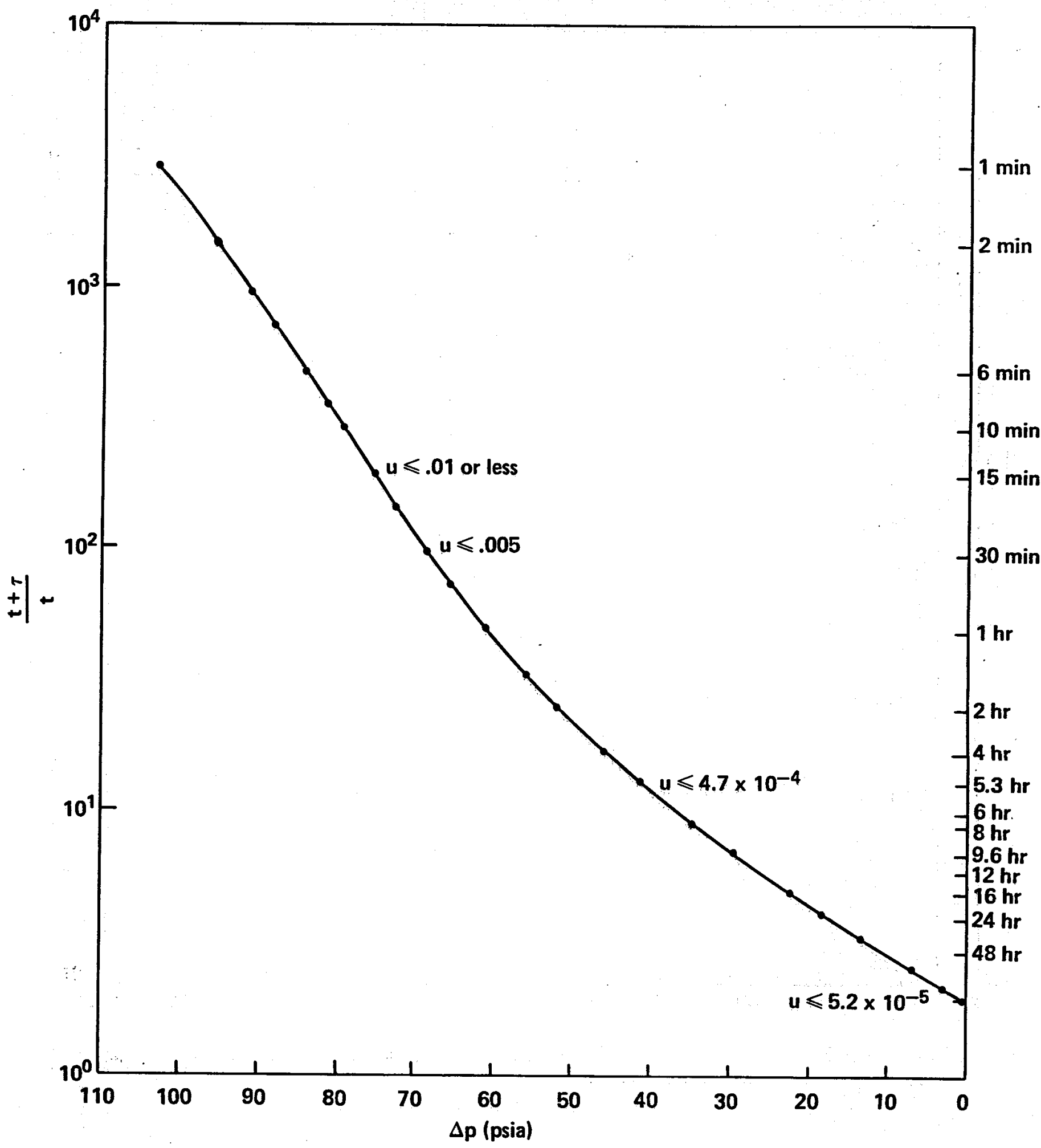




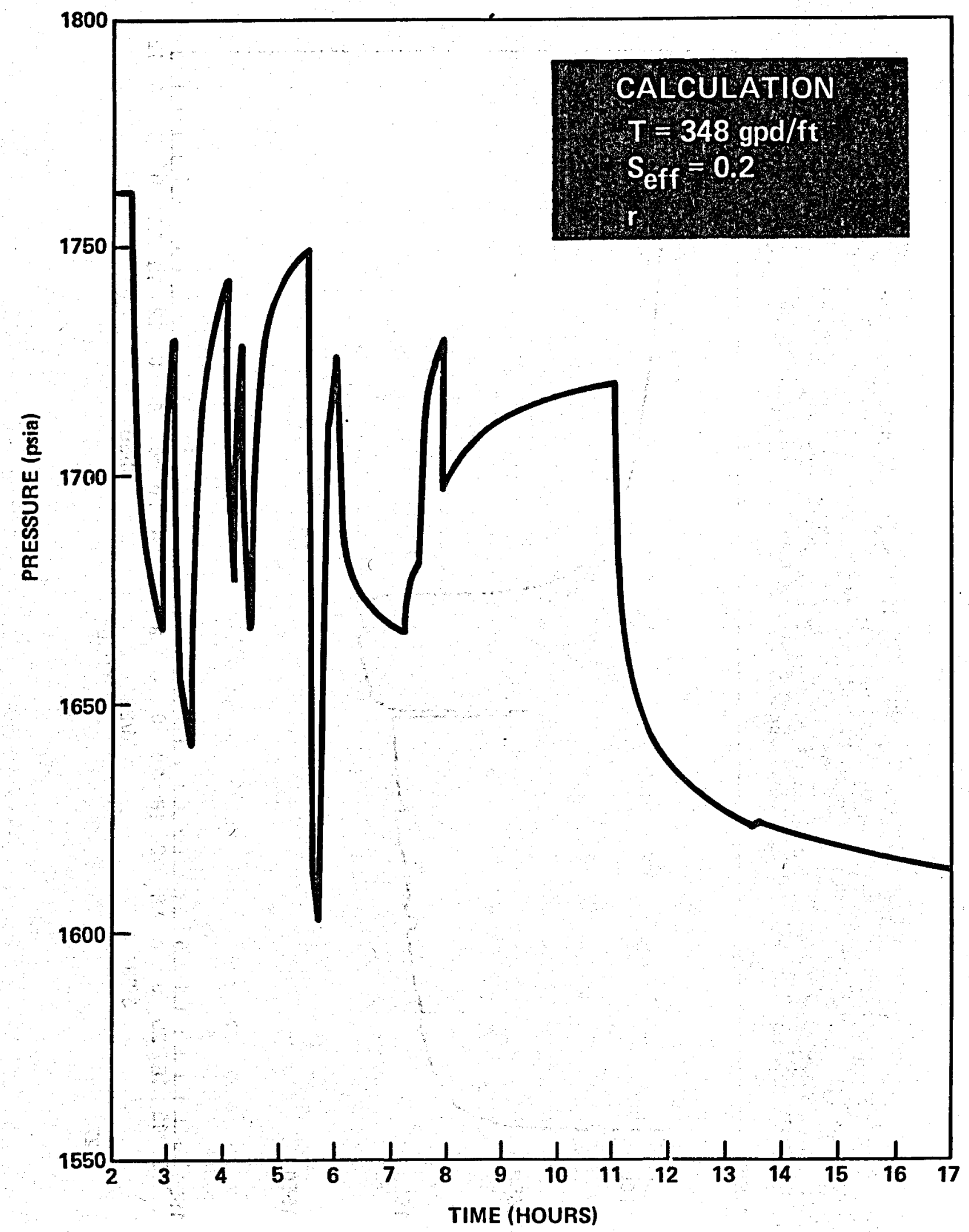




\section{CRISFIELD GT TEST WELL \\ TEST ZONE \# 2 \\ CALCULATIONS}

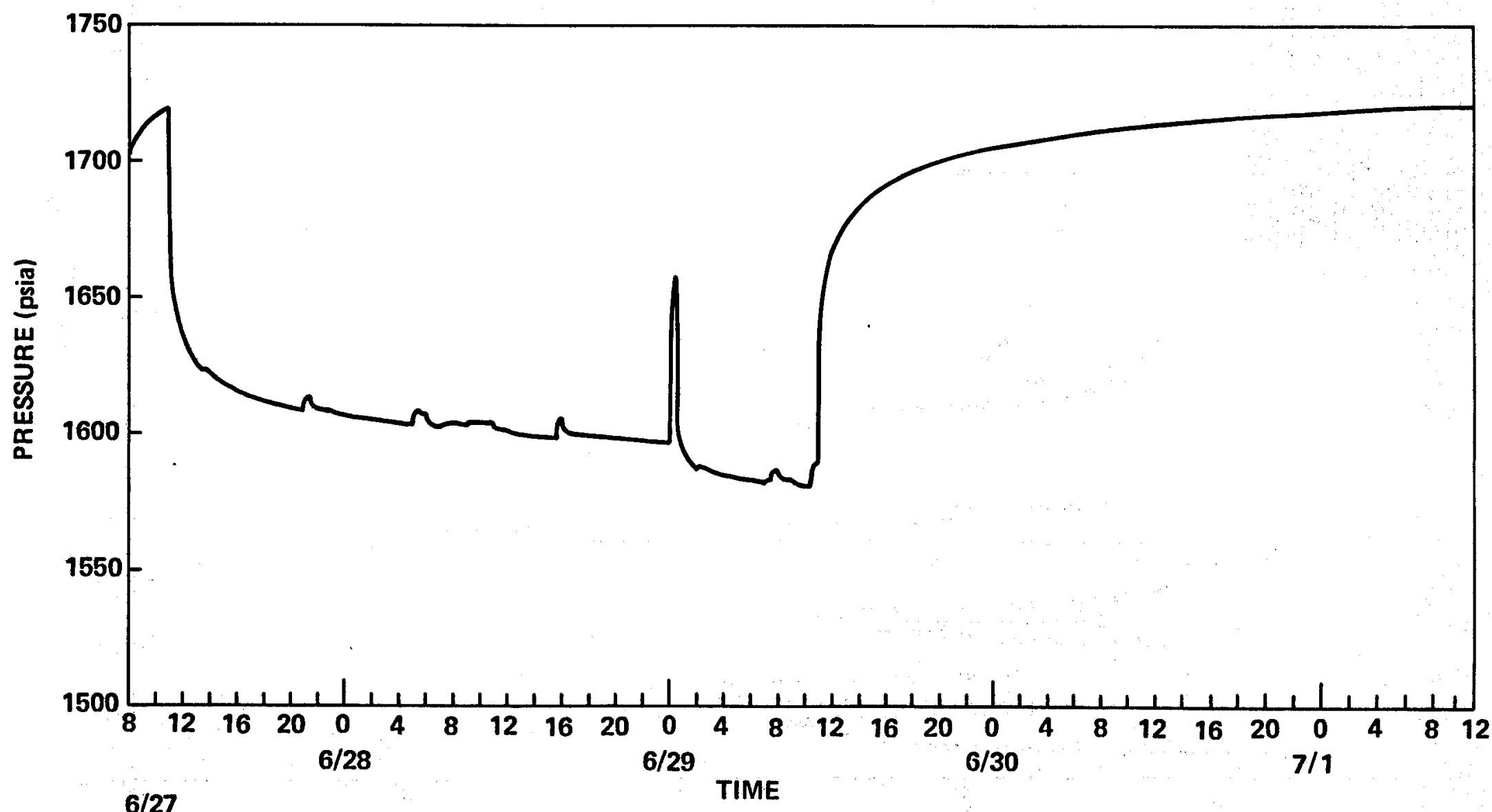

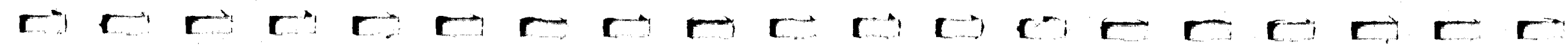




\author{
Geothermal Heating for the \\ Crisfield, Maryland High School
}

by

Fletcher C. Paddison

Applied Physics Laboratory

The Johns Hopkins University 
THE JOHNS HOPKINS UNIVERSITY

APPLIED PHYSICS LABORATORY LAUREL. MARYLAND

\section{Geothermal Energy for Space Heating \\ Crisfield, Maryland High School}

A letter report is available* that discusses in detail the suggested retrofit of the high school in Crisfield, Maryland, and, therefore, this account is very brief.

Figure 1 outlines the discussion. Figure 2 shows the location of the deep geothermal resource confirmation well at the airport in relation to downtown Crisfield, the McCready Hospital, and the Crisfield High, Elementary and Middle Schools. Figure 3 shows the 10-year average temperature time duration history assumed to be representative of the Crisfield area. Figure 4 presents the results of the deep Crisfield well and Fig. 5 the chemistry. of the geothermal water from the lower two aquifers. Figure 6 shows the calculated well drawdown of a geothermal well in Crisfield, Maryland, with a water withdrawal schedule following the assumed degree day history and the peaking system augmenting the geothermal system at ambient temperature below $30^{\circ} \mathrm{F}$. The retrofit parameters are shown on Fig. 7 and Fig. 8 is a skematic of the system. Figure 9 shows the capital costs and the annual operating costs. Figure 10 and Fig. 11 are potential costs vs. depth from water, 011 and gas wells in comparable areas. Figure 12 shows the two types of motor, pump and variable speed drives for geothermal water removal. Figure 13 shows titles of the energy conservation grant program under the National Energy Act for conversion to renewable energy. Figure 14 shows the time for payback of capital costs as function of escalation rate of fossil fuel and percentage of grant funds, if available. Figure 15 summarizes cost effectiveness of geothermal energy for space heating Crisfield, Maryland.

*APL/JHU Letter Report CQO-2544 to DOE/RA, Nov. 12, 1979, "The Crisfleld, Maryland Well and Geothermal Energy". 


\section{GEOTHERMAL ENERGY FOR SPACE HEATING CRISFIELD HIGH SCHOOL}

- Location of high school and deep geothermal well

- Results of deep geothermal test well

- Elements of geothermal space heating

- Cost of deep wells

- Types of pumps considered

- Payback period from fuel saved

Fig. 1 
Legend:

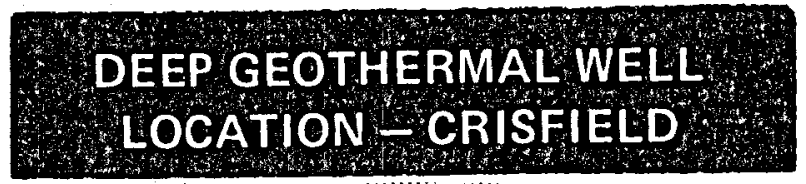

$B=$ Reinjection well

$C=$ Hospital/nursing home

$D=$ High school

$E=$ Elementary school

$F=$ Intermediate school

(I) = Accumulate miles
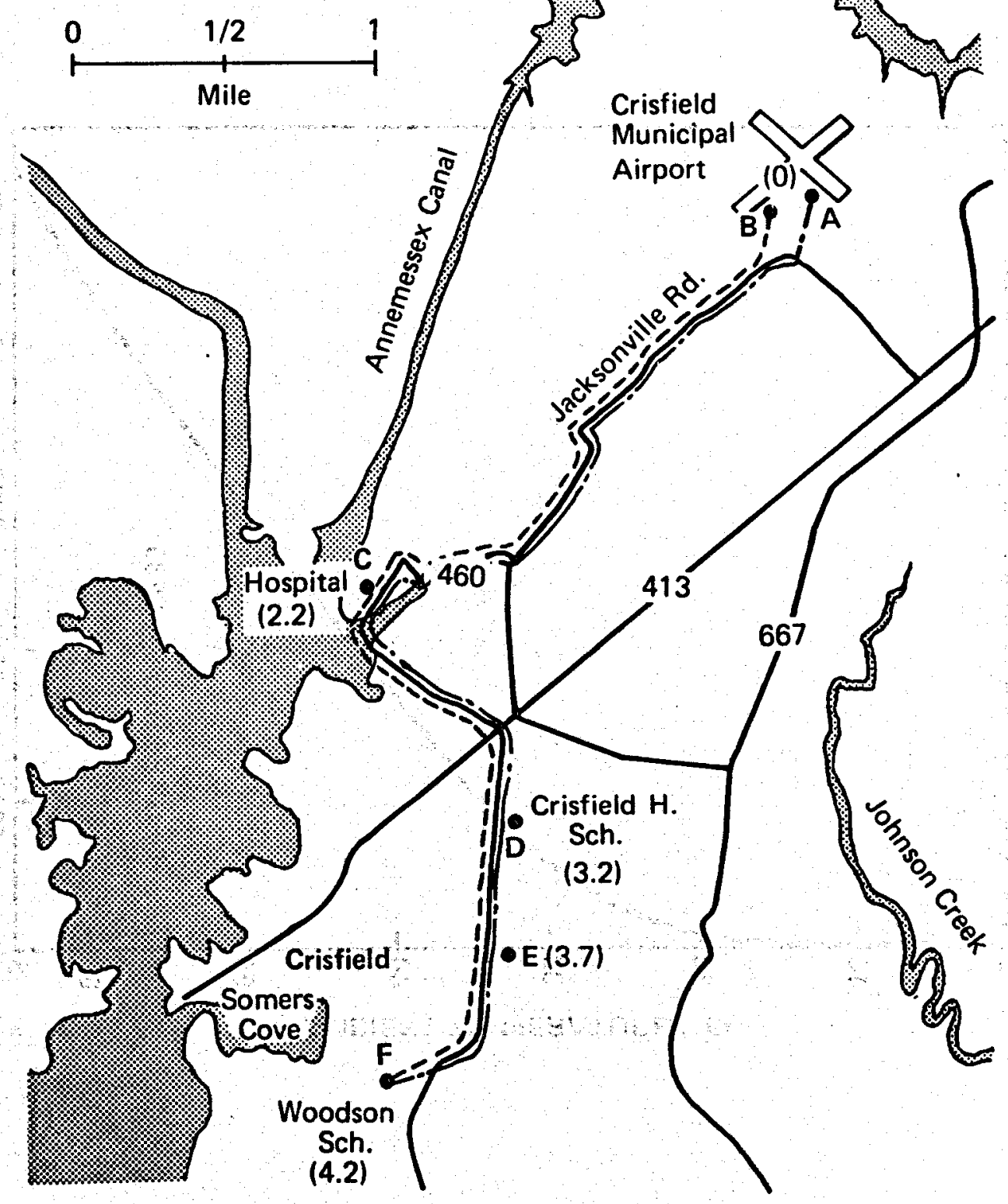

Plumbing to heat three schools and a hospital with airport wells,

F1g. 2 


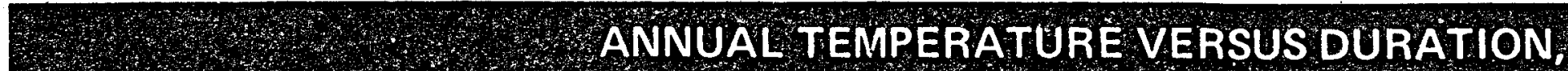
TYPICAL OF SALISBURY, MARYLAND

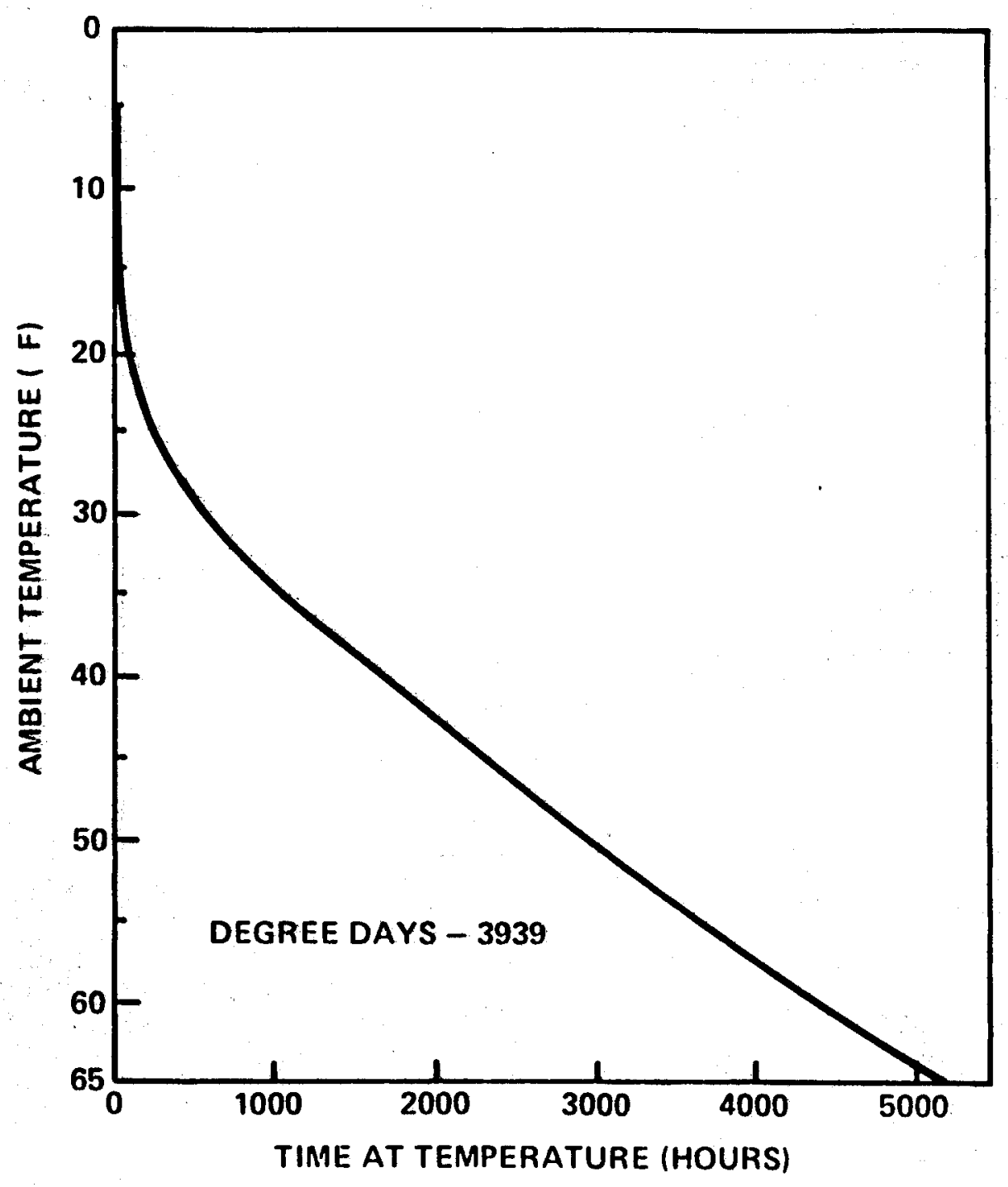

Fig. 3 


\section{DEEP GEOTHERMAL TEST WELL CRISFIELD}

\section{LOCATION}

CRISFIELD MUNICIPAL AIRPORT

3+ MILES FROM HIGH SCHOOL

\section{RESULTS}

AQUICLUDE BETWEEN 2500 AND $2700 \mathrm{ft}$

THREE POTENTIAL PRODUCTION ZONES - UNCONSOLIDATED SAND

$$
\begin{array}{lll}
3798-3846 \mathrm{ft} & \text { NET } 44 \mathrm{ft} & 128^{\circ} \mathrm{F} \\
3986-4032 \mathrm{ft} & \text { NET } 86 \mathrm{ft} & 133^{\circ} \mathrm{F} \\
4148-4223 \mathrm{ft} & \text { NET } 62 \mathrm{ft} & 135^{\circ} \mathrm{F}
\end{array}
$$

TRANSMISSIBILITY - MID-ZONE - $348 \mathrm{gpd} / \mathrm{ft}$

PERMEABILITY - 110 MILLIDARCIES

WATER CHEMISTRY

SIMILAR TO SEA WATER - TWICE AS SALTY

STATUS

WELL ABANDONED

\section{CONCLUSIONS}

SAND CONTROL REQUIRES WATER WELL COMPLETION, i.e., GRAVEL PACK - SCREEN

WELL DRAWDOWN MUST BE MINIMIZED INTERMITTENT USE MODERATE WITHDRAWAL RATES - USE WITH PEAKING SYSTEM REINJECTION REQUIRED

TEMPERATURES ADEQUATE FOR SPACE HEAT NEW WELLS RECOMMENDED NEAR USER COST EFFECTIVE FOR BASELOAD SPACE HEAT MODERATE SIZE BUILDING

$$
\text { Fig. } 4
$$




\section{CHEMICAL ANALYSIS OF CRISFIELD}

GEOTHERMAL WELL-WATER

ITEM

$\mathrm{Cu}$

Zn

BORON

ARSENIC

CHROMIUM

$\mathrm{Pb}$

CADMIUM

$\mathrm{Na}$

$\mathbf{K}$

Fe

$\mathrm{Mg}$

Molyb

$\mathrm{CaCO}_{3}$

$\mathrm{MgCO}_{3}$

CARBONATE

BICARBONATE

TOTAL CHLORIDES

SULPHATES

DISSOLVED SILICATES

NITRATE

NITRITE

TOTAL ORGANIC CARBON

DENSITY

CONDUCTIVITY

ph

$\mathrm{Hg}$

Ca

HARDNESS

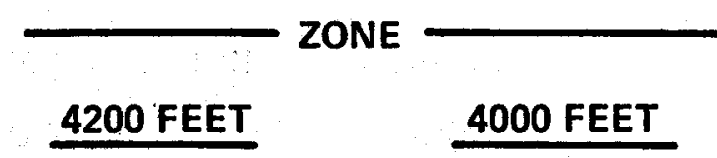

$0.25 \mathrm{ppm}$

1.3

9.0

$<0.1$

$<0.1$

$<0.1$

28,000 ppm

300

$16 \mathrm{ppm}$

656 ppm

$<0.2$

15,800

2,276 ppm

0.0

$98 \mathrm{ppm}$

39,427

588

19.5

$1.8 \mathrm{ppm}$

$<1.0$

34

$1.042 @ 82^{\circ} \mathrm{F}$

$53,000(?)$

6.3

$<0.005$ ppm

6336

18,500
$0.4 \mathrm{ppm}$

0.36

8.6

$<0.02$

0.3

$<0.1$

$<0.1$

22,000

310

11 ppm

670 ppm

$<0.1$

7,600

2,759

0.0

72 ppm

37,052

620

39

2.3 ppm

$<1$ ppm

28

$1.030 \mathrm{gm} / \mathrm{cm}^{3}$ @ $126^{\circ} \mathrm{F}$

68,000

6.4

$<0.005$ ppm

3040

10,359

Fig. 5 
…

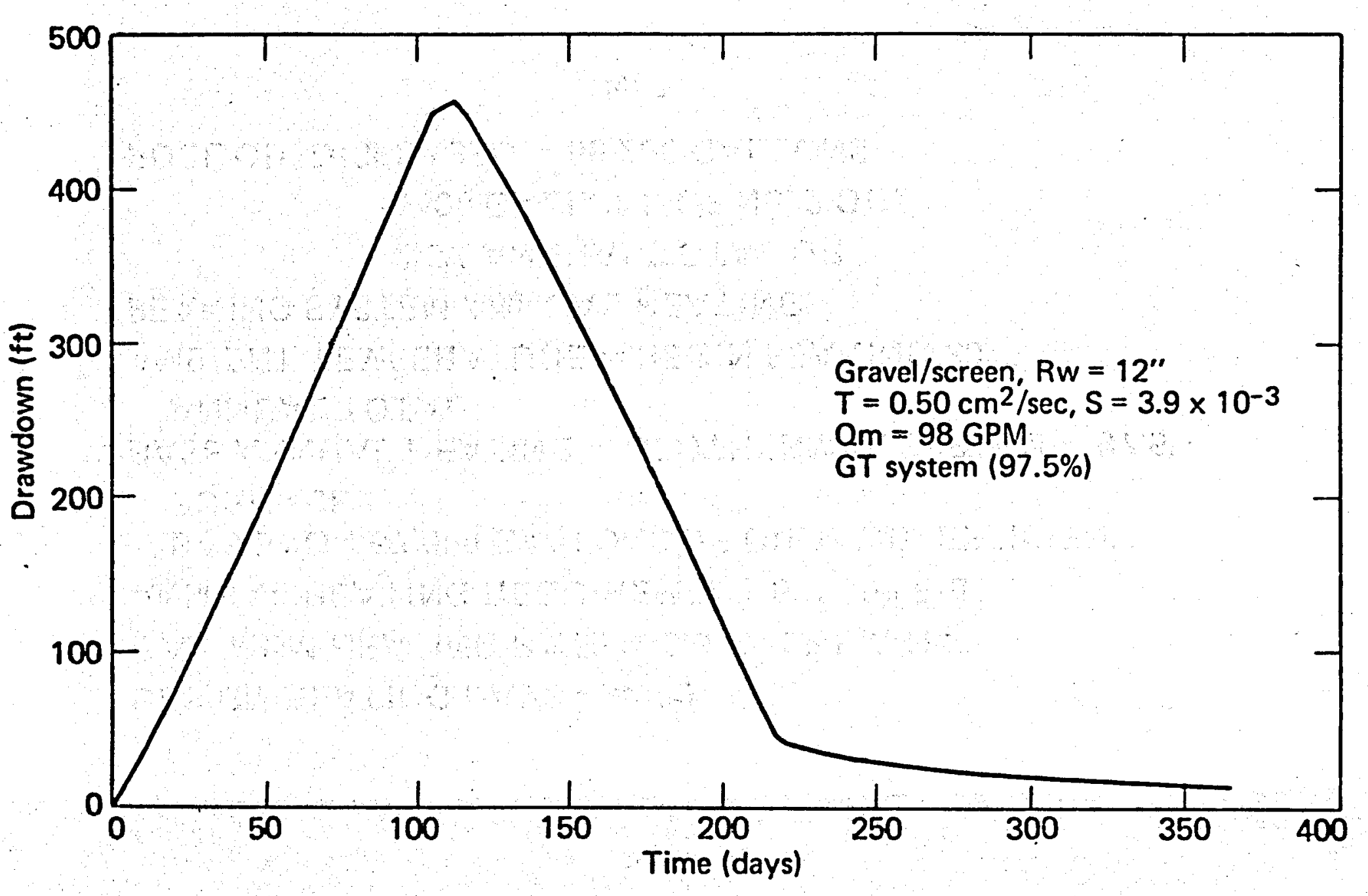

Crisfield well drawdown (1st yr).

Fig. 6 


\section{SUMMARY GEOTHERMAL RETROFIT CRISFIELD HIGH SCHOOL.}

DESIGN HEATING DAYS - 4000

MAXIMUM HEATING RATE - $3.6 \times 10^{6} \mathrm{Btu} / \mathrm{Hr}$ ANNUAL HEATING REQUIREMENT $5 \times 10^{9} \mathrm{Btu}$

BASED ON 57,600 GALLONS OF OIL @ 70\% EFFICIENT FURNACE

BASE ANNUAL HEATING - GEOTHERMAL SYSTEM - 97.5\% ANNUAL TOTAL

AMBIENT TEMPERATURE - BEGIN PEAKING $30^{\circ} \mathrm{F}$

PEAKING SYSTEM ANNUAL HEATING:

2.5\% ANNUAL TOTAL OR 1400 GALLONS OF No. 2 OIL

FUEL OIL DISPLACED - 56,200 GALLONS

Fig. 7 


\section{SCHEMATIC - GEOTHERMAL HEATING SYSTEM}

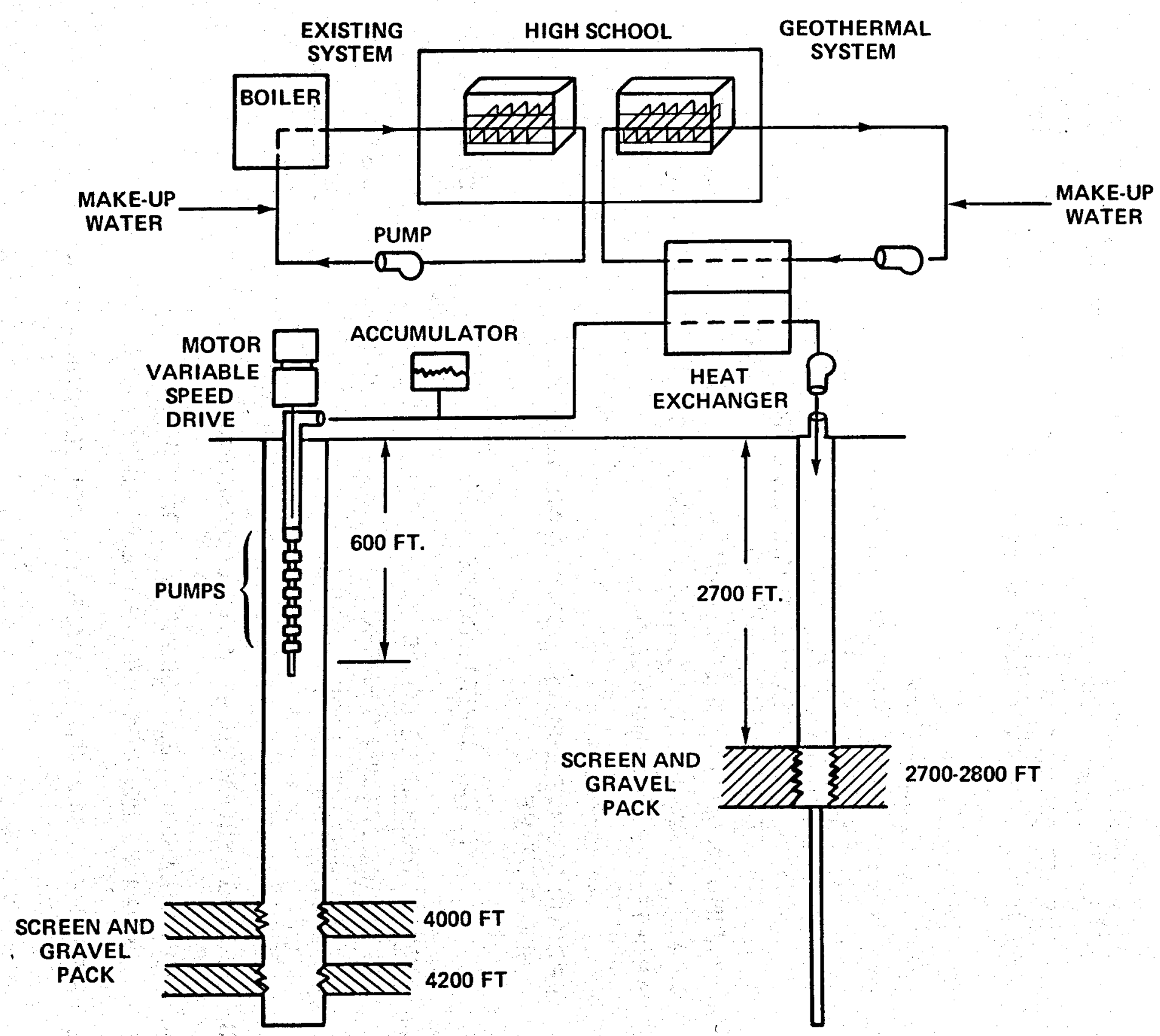

Fig. 8 


\section{COSTS GEOTHERMAL RETROFIT CRISEIELD HIGH SCHOOL}

1. CAPITAL COSTS

ADDITIONAL RADIATORS

\$110K

NEW WELLS - WITH SCREEN AND GRAVEL PACK

$\$ 250 \mathrm{~K}$

$\begin{array}{lr}\text { PRODUCTION }(4200 \mathrm{ft}) & (\$ 125 K) \\ \text { REINJECTION (3000 ft) } & \text { (\$100K) } \\ \text { (IVITH SMALL } & \end{array}$

(WITH SMALL DIAMETER EXTENSION TO $4200 \mathrm{ft}$ ) TESTING AND LOGGING (\$ 25K)

PUMPING WELLS TO SCHOOL (1 MILE)

$\$ 200 K$

HEAT EXCHANGER, PUMPS, WELLHOUSE, ETC.

$\$ 100 \mathrm{~K}$

ARCHITECTS AND ENGINEERING

SUBTOTAL

\$ 70K

$\$ 730 \mathrm{~K}$

PRODUCTION WELL PUMP, MOTOR, VARIABLE

$\$ 22 K$

SPEED DRIVE

TOTAL CAPITAL COSTS

$\$ 752 K$

2. ANNUAL OPERATING COSTS

ELECTRICAL PUMPING ENERGY

$\$ 3.5 K$

ANNUAL INSPECTION OF PUNIPS

$\frac{\$ 2.5 K}{\$ 6.0 K}$

3. PEAKING SYSTEM OIL - 1400 GALLONS/YEAR

4. FUEL OIL DISPLACED - 56,200 GALLONS/YEAR

1979-1980 SAVINGS @ $75 \mathrm{~d} / \mathrm{GALLON}=\$ 42 \mathrm{~K}$

5. FIRST YEAR SAVINGS TO AMORTIZE CONVERSION - \$36K

F1g. 9 


\section{AVERAGE DRILLING COST FOR APPALACHIAN AREA}

\section{(1 to 6 KFT DEPTH)}
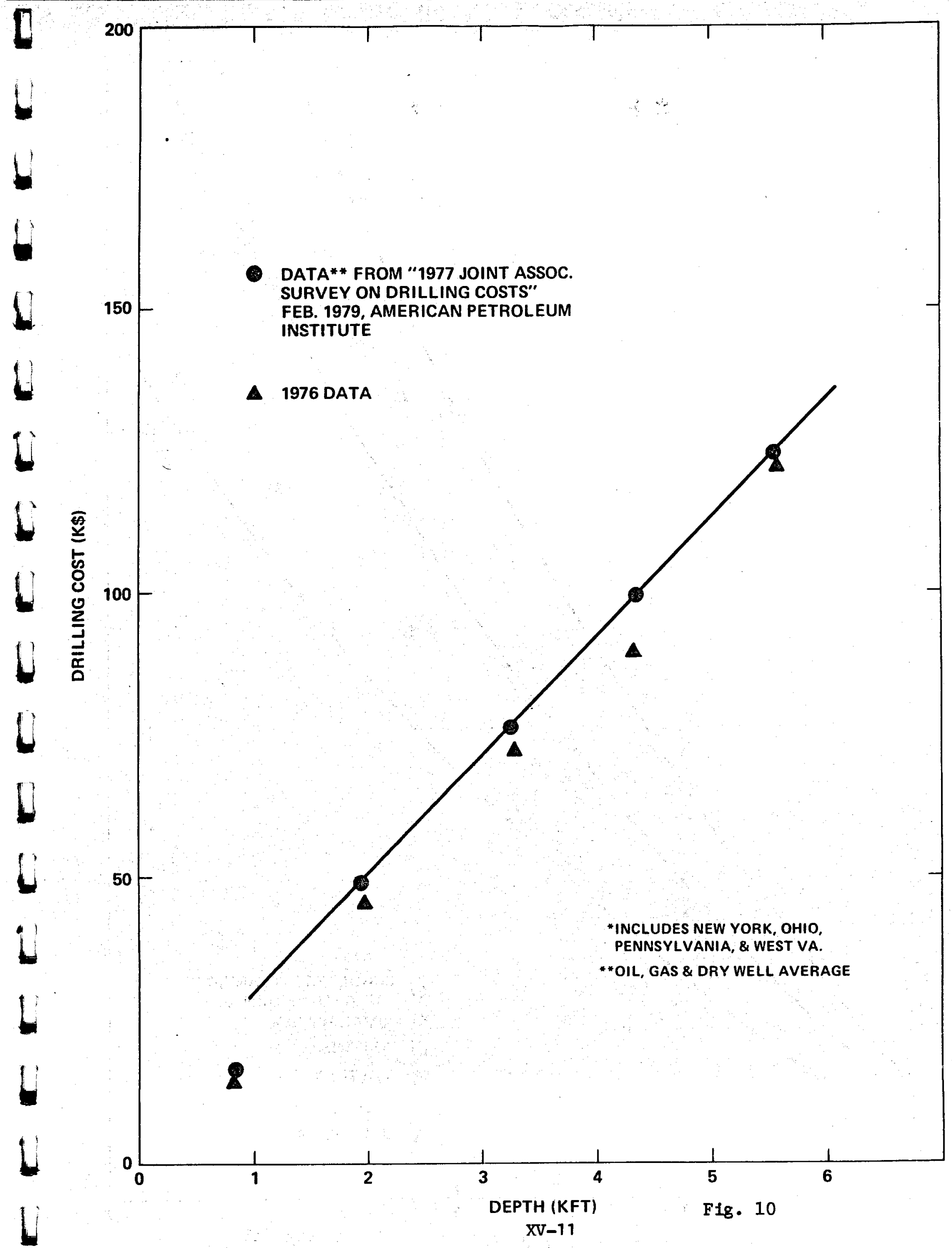


\section{WELL COST COMPARISON}

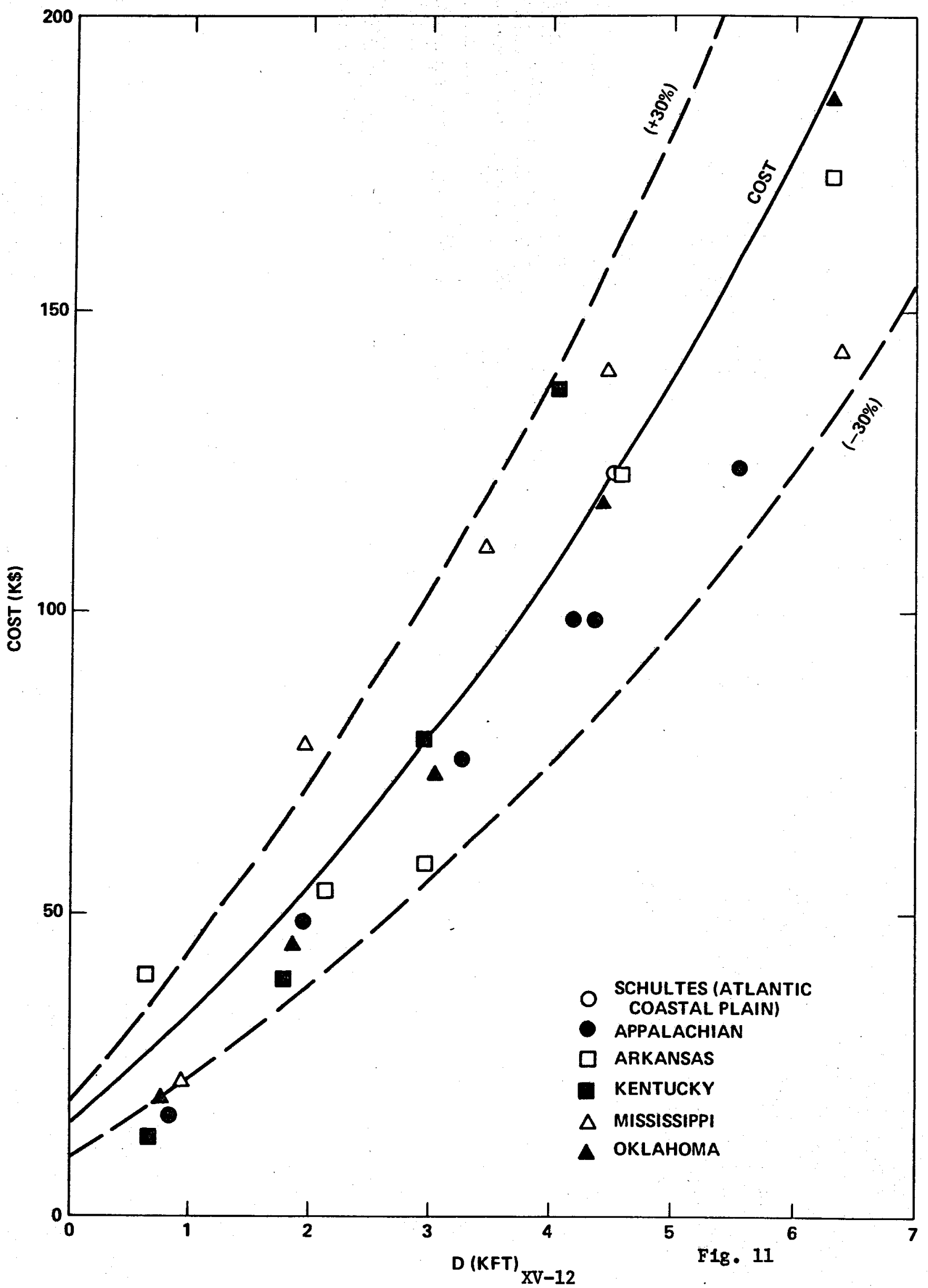


PUMPS TO WITHDRAW GEOTHERMAL WATER

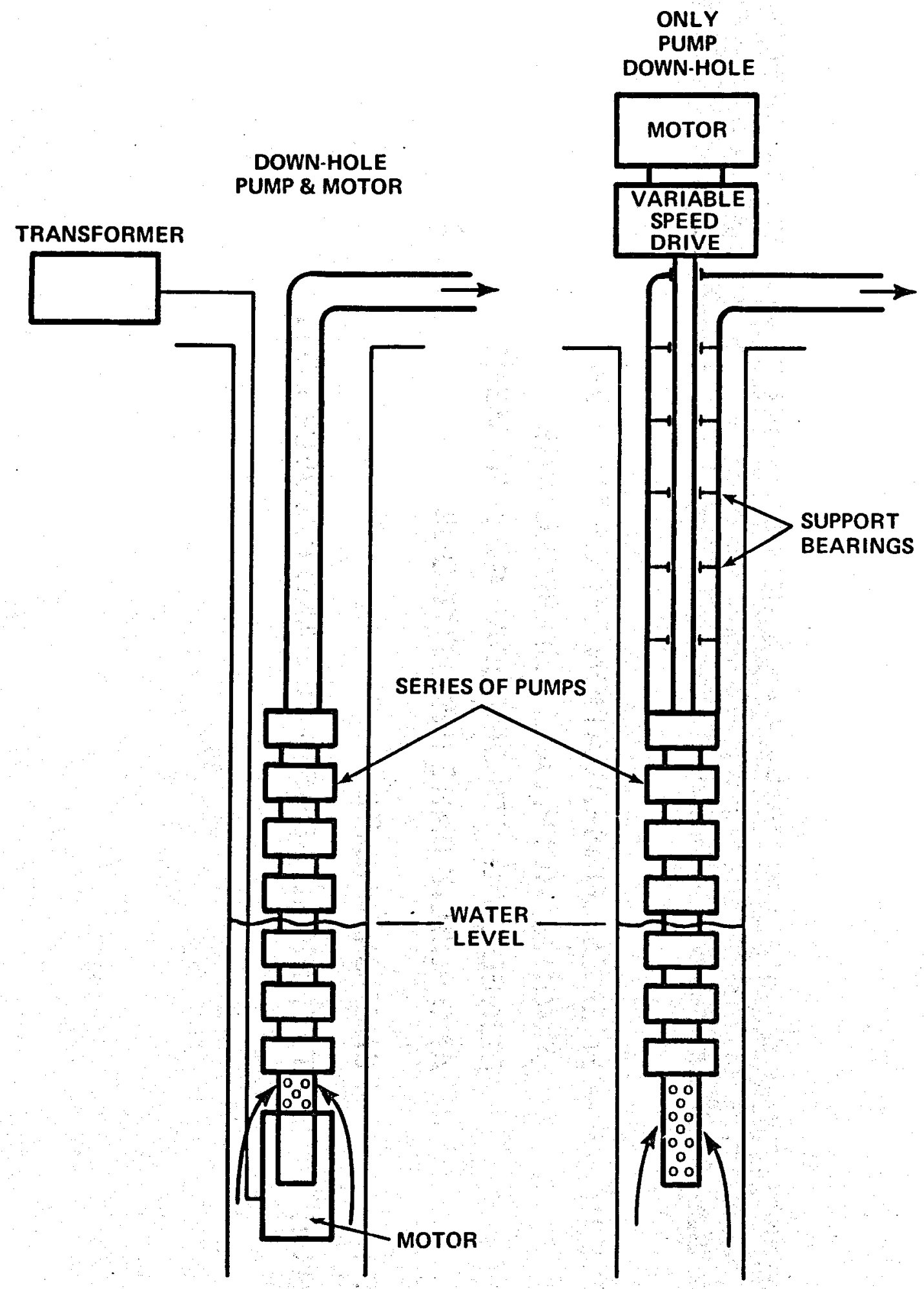

FIg. 12 


\section{THE NATIONAL ENERGY ACT}

TITLE III - ENERGY CONSERVATION PROGRAMS FOR SCHOOLS, HOSPITALS AND BUILDINGS OWNED BY UNITS OF LOCAL GOVERNMENT AND PUBLIC CARE INSTITUTIONS.

PART I - ENERGY AUDITS

PART II - TECHNICAL ASSISTANCE AND PROJECT COST

Fig. 13

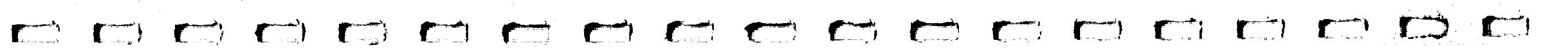




\section{CRISFIELD HIGH SCHOOL CAPITAL RECOVERY TIME}

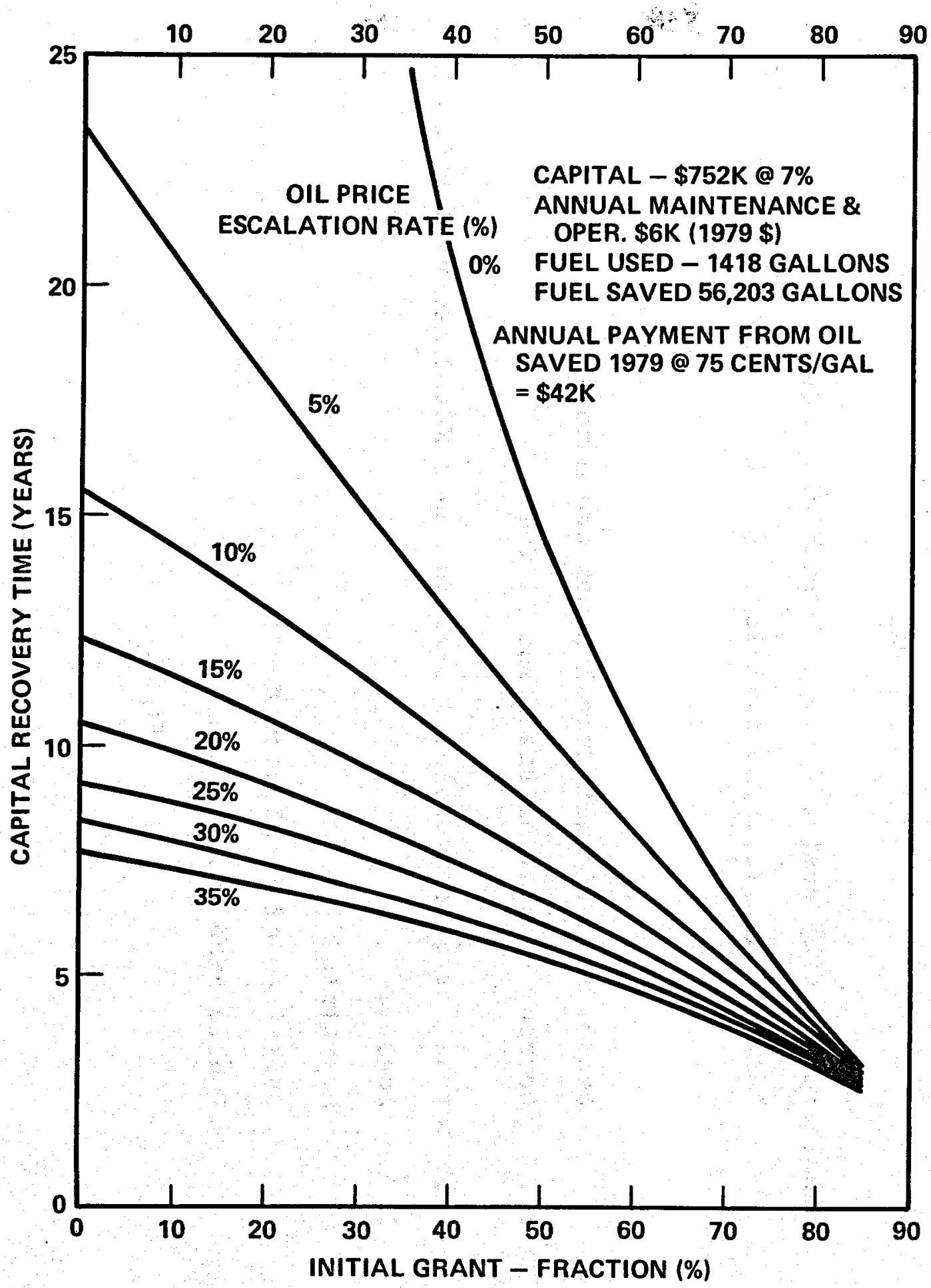

Fig. 14 
SUMMARY

Geothermal energy cost effective - Crisfield, MD:

For moderate to large bulldings

Together with peaking system to - Limit withdrawal rates

- Limit drawdown

Use of reliable withdrawal pumps and motors

Current escalation rates fossil fue $i$

Geothermal energy conversion a bargain under NEA Conservation Grants

Schools

Hospitals

Bulldings of local government

Public care Institutions

F1g. 15 


\section{Status Report}

Engineering and Economic Studies, Direct Application of East Coast Geothermal Resources in the Frozen Food Industry

(Campbell Soup Company)

\section{by}

Ray Costello and Martin Knebel Burns and Roe Industrial Services 


\section{STATUS REPORT}

\section{Engineering and Economic Studies for Direct \\ Application of East Coast Geothermal \\ Resources in the Frozen Food Industry}

\section{by}

Martin E. Knebel and Raymond M. Costello

\section{ABSTRACT}

The objective of the DOE Geothermal Energy Development Program is to provide the nation with an economically and environmentally acceptable energy resource to supplement present energy sources. To accomplish this, the early development of a viable and growing geothermal industry is required. The project discussed herein concentrates on site specific engineering and economic studies of the moderate temperature hydrothermal resources in the Atlantic Coastal Plain of the United States. In particular, under contract to DOE, an industrial team of Burns and Roe Industrial Services Corporation (BRISC) and Campbeil Soup Company (CSC) is studying the conversion of the existing CSC frozen food plant in Salisbury, Maryland, to utilize the resources currently being explored by DOE in that locality. BRISC is the prime contractor and CSC participates as a subcontractor. The 36 week program is currently in its fifth week. Since definitive reservoir data for the area is not yet available for analysis, a parametric study over a reasonable range of reservoir design parameters will be performed. Economic factors will also be 
varied. In addition, a task to develop a reservoir confirmation plan has been included in the scope of work.

The specific objective of this study is to provide a data base which can be used as soon as the specific reservoir data becomes available to assess the practicality of utilizing the geothermal resources by retrofitting the existing frozen food plants. In addition to the Salisbury plant, CSC also operates a plant in Pokomoke City, Maryland which is 20 miles south of Salisbury.

Currently, the project team is in the midst. of an effort to idenfity processes within the plant which appear most attractive for conversion to utilize the geothermal energy.

TECHNICAL DISCUSSION

Study Objectives

The overall objective of the proposed study is to develop a base of engineering, economic and institutional data. When combined with information from the test drilling program already initiated by DOE on the east coast, this data base will permit rapid assessment of the practicality of utilizing the geothermal resources of Maryland in the frozen food industry via retrofits of existing plants.

In order to achieve the overall objective, efforts during the program will be directed towards attainment of certain specific objectives. These specific objectives all involve the development of answers to certain questions which are stated below: 
a. Based on the best available data, what ranges of values can reasonably be expected for the various items of geothermal reservoir data in the Salisbury, Maryland area (1.e. reservoir size, well location, depth, flow capacity, temperature, drawdown, etc.)?

b. For the ranges of values developed in (a), what processes within the CSC Salisbury plant can be adapted to utilize geothermal energy in place of energy sources currently used?

c. What plant modifications would be required to convert the processes defined in (b) to use geothermal energy?

d. What design is proposed for the geothermal production well and supply system to the CSC plant (i.e. pumps; pretreatment system, if any; piping; controls; etc.)?

e. What approach is recommended or required for the disposal and/or utilization of the cooled geothermal brine?

f. What environmental emissions may be of concern and what quantities are expected? What technology is available for control of these emissions?

g. Will a positive net energy utilization result from this application?

h. What is the cost of energy when supplied by the geothermal reservoir and when supplied in conventfonal forms? How sensitive are these costs to the range of reservoir data developed in (a)?

1. What social, financial, environmental or legal barriers to the proposed application exist? What ways are available to eliminate or reduce these barriers?

Background

This section provides some background and an explanation of the rationale for the general approach chosen by the BRISC/CSC team to further the development and exploration of the nation's eastern geothermal resources. Subsequent sections of this report will describe the study plan in more detạil. 
The development efforts intended to locate, quantify and characterize the geothermal resources in the eastern United States are relatively new. (1) (2) * The Department of Energy, Division of Geothermal Energy (DOE) has a program underway to define the Atlantic Coastal Pla in geothermal resources. This program is being carried out by Virginia Polytechnic Institute and State University (VPI \& SU). About 50 sites were selected along the Atlantic Coast from New Jersey to Georgia. Test wells to depths of $1000 \mathrm{ft}$. to $1800 \mathrm{ft}$. were drilled by Gruy Federal, Inc. and Energy Service Company at these sites and temperature gradients and core sample conductivity measurements were obtained. Based on these results, the program was extended and a $4000 \mathrm{ft}$. deep test well has been drilled at Crisfield, Maryland. It is anticipated that other deep wells will also be drilled.

Salisbury, Maryland, the site of the frozen food plant owed by Campbell Soup Company (CSC), is in the heart of the area selected for the test wells discussed above. In addition to verifying the geothermal energy available in the area, it is necessary to define practical applications for its use. The CSC plant is potentially such an application, as will be indicated in a subsequent section of this report which describes the processes involved. It is desirable to bring the level of development of east coast reservoirs into parity with other sections of the country in the shortest possible time. To accomplish this, a base of detailed engineering and economic data for various applications must be developed in parallel with the test drilling and should be available when the testing is complete. This data base will permit a rapid evaluation of the usefulness of the verified resources and will guide the formulation of strategy for subsequent development efforts. One policy decision *Numbers in () refer to references at end of paper. 
which might be affected by the research proposed herein would be the location of the deep wells which DOE/DGE plans to drill. Certainly, the availability of attractive and available applications will be a major factor to be considered when deciding on the location of these deep wells. The fact that this is a retrofit application in an existing plant should result in a more rapid demonstration of the geothermal energy application than if an entire new plant construction phase was required.

Detailed engineering data is required in order to estimate life cycle energy costs for any complex system. While such information can be developed for the CSC plant battery limits given specific data concerning the energy resource, such data are not yet available for the east coast geothermal reservoirs. However, based on data from the continuing test program (3), reasonable judgments can be made concerning the probable ranges within which this data will fall in the Salisbury, Maryland area. Then, in order to produce an easily used and reliable data base, a series of design and economic studies including consideration of institutional factors will be performed for a matrix of values within these ranges. The results of this parametric study will then be presented in a format which clearly indicates the various combinations of factors for which the utilization of geothermal energy at the CSC plant would be attractive compared to the utilization of conventional energy sources. In addition, the format will permit the potential savings in energy costs for each combination to be readily obtained. This will permit comparisons to be made with the results of other studies so that the most attractive applications for geothermal energy in this area can be pursued by DOE/DGE. 
Study PIan

The proposed program is composed of five tasks. In some cases these tasks are subdivided into various subtasks, each of which is designed to achieve a specific objective. In general, Burns and Roe Industrial Services Corporation (BRISC) will be responsible for all design and cost estimating work. CSC will provide all process information and energy usage and energy cost data required to support the design and economic analysis efforts. CSC will also provide major inputs to the analysis of institutional factors which will be prepared by BRISC.

The technical objectives of each task and subtask along with a brief description of the methods to be used in the attainment of each are indicated in the following paragraphs.

Task 1.0 - Engineering and Design Studies

Based on available published data and contacts with other investigators (3) (4) (5) a prediction will be made of the expected range into which the relevant geothermal reservoir data (i.e. temperature, flow capacity, depth, etc.) for the Salisbury, Maryland area will fall. Process data, plant drawings and energy data for the existing plant will be compiled. Based on this information, a design concept will be developed for the entire geothermal energy system from production well through the plant to final brine disposal.

More than one conceptual design may have to be developed to cover the range of uncertainty involved in the geothermal reservoir data.

A conceptual design package will be developed inciuding process flow sheets and instrumentation diagrams, site plans, plant arrangement drawings 
and functional specifications for all new equipment. Drawings may be either marked-up copies of existing plant drawings or originals produced specifically for this contract.

Task 2.0 - Cost Estimates and Economic Analysis

Based on the detailed design(s) produced in Task 1.0, a parametric analysis of capital and operating costs will be performed which covers the range of geothermal design data developed in Task 1.0. A discounted cash flow rate of return type of analysis will be utilized to evaluate the economic viability of retrofitting the existing plant to incorporate the use of geothermal energy in place of all or part of the conventional energy sources currently being used. The cost of energy both when supplied in conventional form and when supplied by the retrofitted geothermal system will be calculated over a 30-year life. An order of magnitude estimate will also be made of the difference in energy costs that might occur if a similar plant were designed from the outset to utilize geothermal energy in lieu of conventional sources.

Task 3.0 - Analysis of Institutional Factors

Relevent social, financial, environmental, legal and regulatory institutional relationships will be examined and ways to el iminate any barriers that may be present against the proposed application will be explored.

Task 4.0 - Development of Reservoir Confirmation Plan

Based on results from the other tasks in this study, suggestions as to possible alterations of the existing DOE East Coast Geothermal Development Plan will be proposed. 
Task 5.0 - Reports

All reports required by DOE will be prepared and issued.

Project Schedule

Exhibit 1 contains a graphic schedule of activities and milestones on a task-by-task basis. During the course of the project, the various design and estimating activities will be broken down into more detail to insure coordination and timely flow of information between the various disciplines (i.e. mechanical, electrical, civil, etc.). Project Status

This program has been underway during the past four weeks. Efforts to date have been concentrated on the geothermal potential of the Salisbury area and on identification of processes within the plant which appear most suitable for conversion to a geothermal source of energy supply. Frozen Food Plant

The Campbell Soup Company owns and operates a frozen food processing plant in Salisbury, Maryland, in the heart of the geothermal well test area. The location of the plant is shown in Exhibit 2. Salisbury, with a population of 15,000, is located on the Delmarva Peninsula, six miles from the Delaware border. The processing plant is situated just southwest of the Salisbury town limits in an industrial-residential area. Salisbury is approximately 30 miles from Crisfield, the site of the deep well discussed earlier.

The Salisbury plant produces "Swanson" products, convenience foods, more commoniy known as "TV dinners". Another CSC plant at Pokomoke City produces frozen pizza pies and other convenience food products. The Pokomoke plant is 
28 miles from Salisbury and 22 miles from Crisfleld. A CSC poultry processing plant is located in Chestertown, Maryland, with frozen food plants in other states as well.

The processing plants use steam from $\# 6$ oil-fired bollers for manufacturing, plant heating and services. Steam is used for all the cooking, sterilization and heating, either directly or indirectly.

Exhibit 3 shows typical usage for the Salisbury and Pokomoke

plants. Since the Salisbury plant uses up to twice the services required by the Pokomoke plant, the Salisbury plant, was the plant selected for further study.

Exhibit 4 provides an indication of the heating requirements in the Salisbury plant. This study will be directed towards those processes which appear to be best able to utilize the geothermal potential of the Salisbury area. 


\section{REFERENCES}

1. F.C. Paddison, C.S. Leffel, W.J. Toth, R.S.P. Weissbrod; "Direct Applications of Geothermal Energy in the Eastern United States and Estimates of Life Cycle Costs"; Presented at American Institute of Industrial Engineers Seminar; October 31, 1978.

2. Geo-Heat Utilization Center Quarterly Bulletin; July 26, 1978; Pages 11-12; Vol. 3; No. 4

3. J.K. Costain, L. Glover III, A.K. Sinha; "Evaluation and Targeting of Geothermal Energy Resources in the Southeastern United States Progress Report - October 1, 1976 - March 30, 1979; Virginia Polytechnic Institute and State University; Reports VPI \& SU-5648 1 through 6 to present.

4. Near Normal Geothermal Gradient Workshop, ERDA-76-11, UC66A, March, 1975.

5. American Association of Petroleum Geologists (AAPG) and USGS 1975 Geothermal Gradient Map of North America, USGS Scale 1:5 $\times 10^{6}$. 
Exhibit 1

Project Work Schedule and Milestone Chart

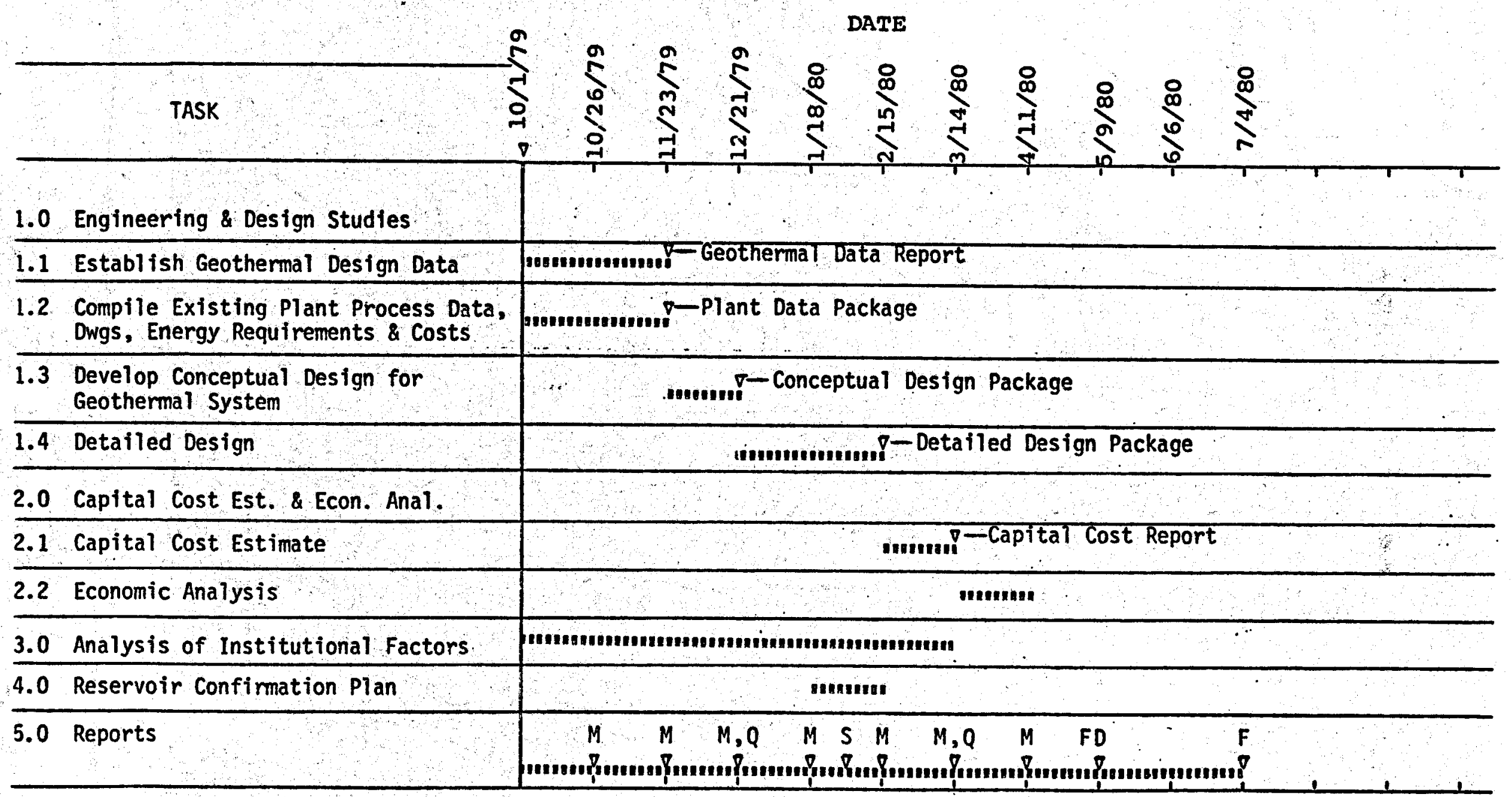

S - Status Review with DOE

M - Monthiy Progress Reports

Q - Quarterly Progress Reports
FD - Final Report Draft to DOE

F - Final Report Release

$\checkmark$ - Milestone 

DELAWARE

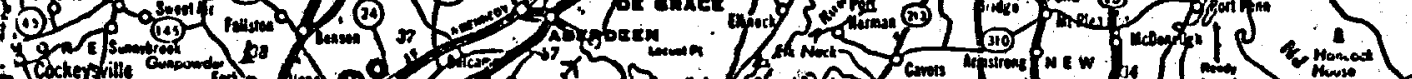

1 (1)

A. 10 .

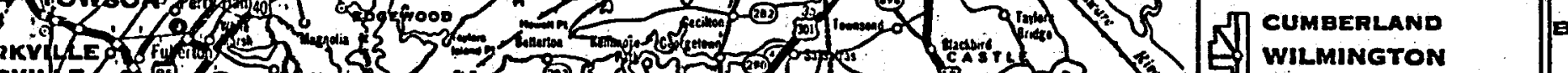

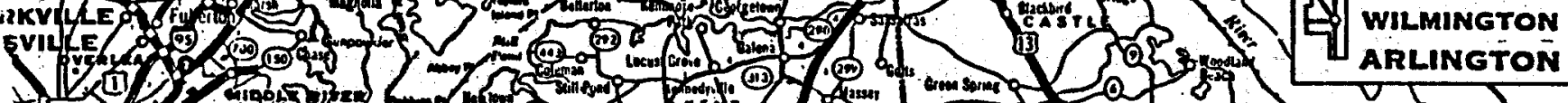
Fon

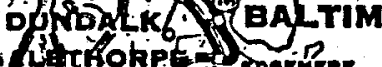

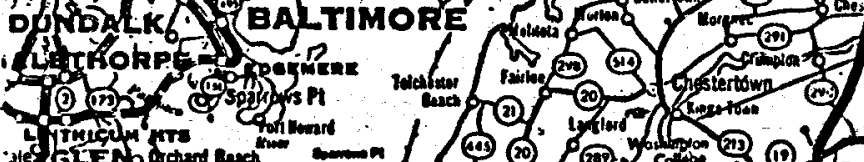

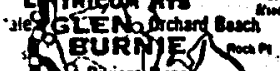

(2)

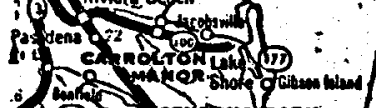

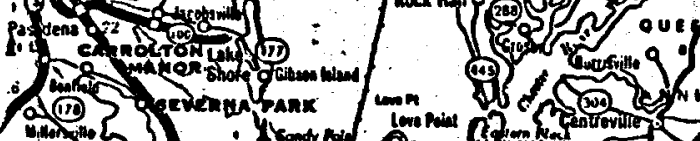
(IS (iii) (2)

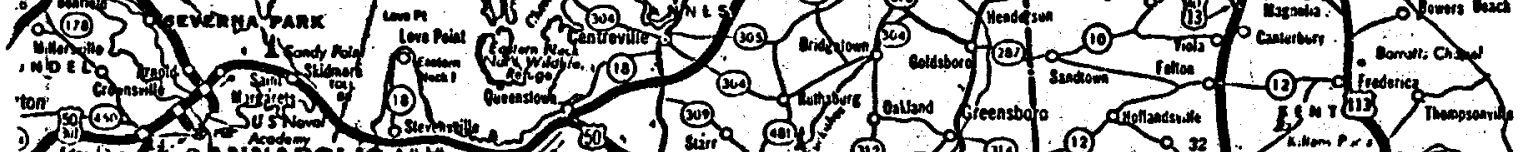

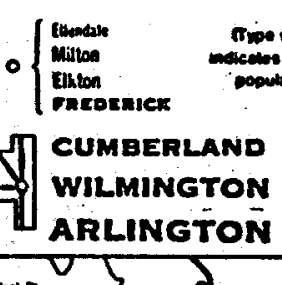

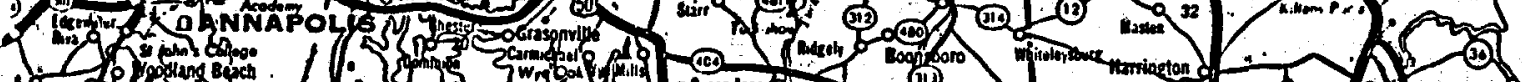
S. Af Dif

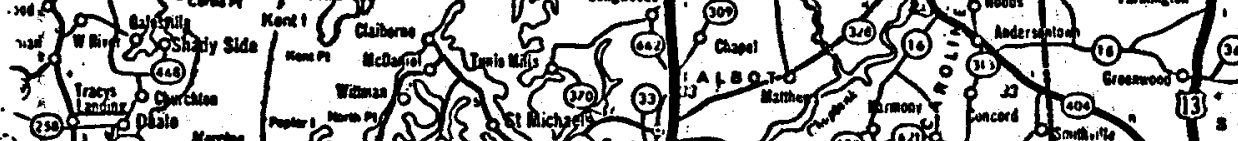
(30)

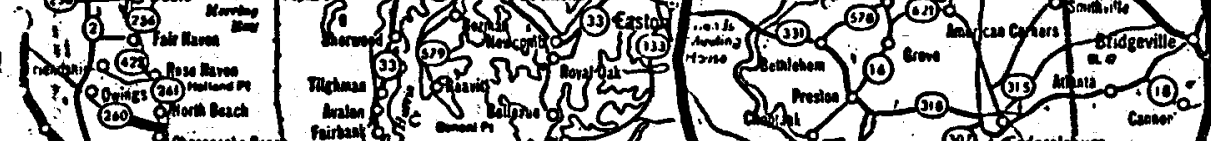

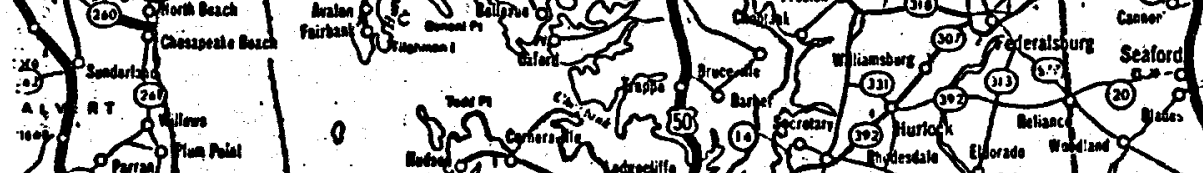

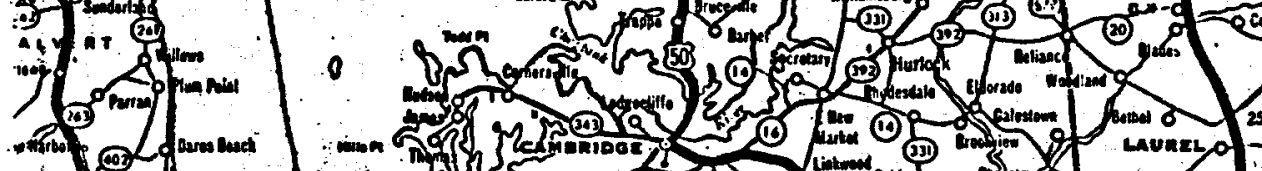

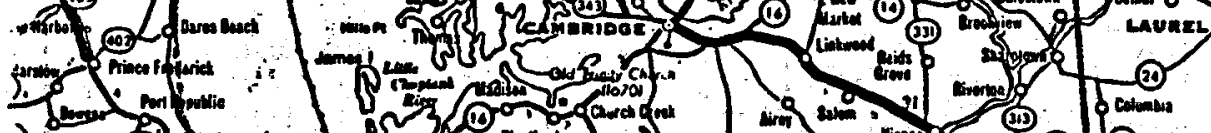

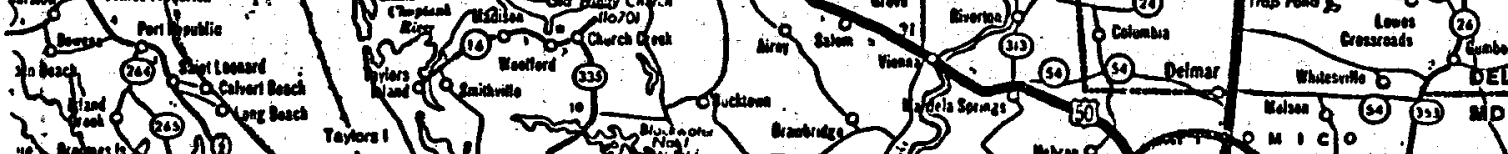

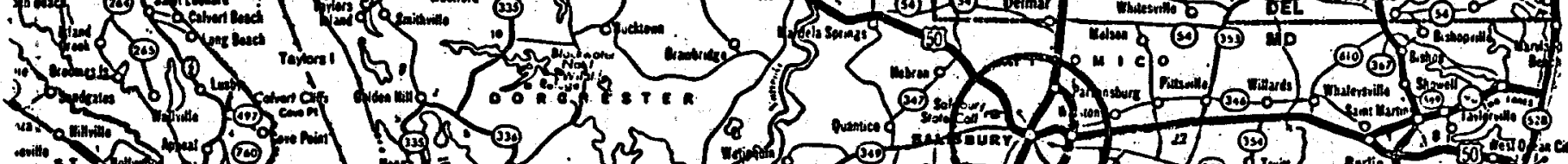
(1) (2)

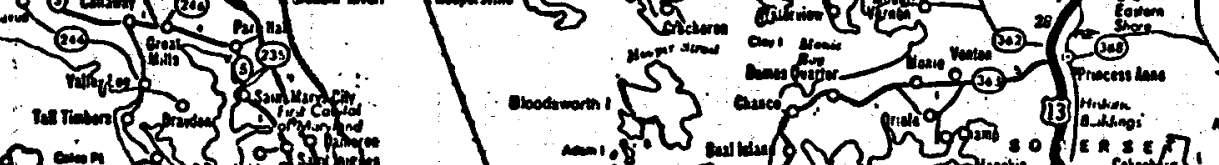
(2)

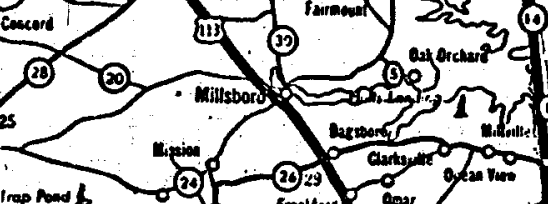

(n)

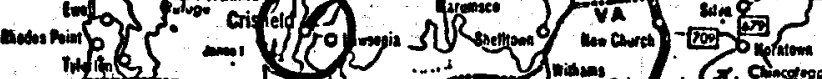

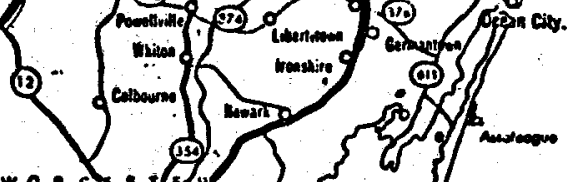


Typical Water Requirements

of Frozen Food Plants

\section{Salisbury Pokomoke}

Boiler Feed Water

Temperature, OF

Average Rate, GPM

53

92

Annual Usage, Gals.

$20,000,000$

32

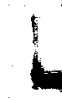

Raw Water - Boiler Feed

Boiler Make-up Temp., OF

Average Rate, GPM

60

37

63

Annual Usage, Gals.

$14,000,000$

22

1

1

Hot Water - Plant Use

Average Rate, GPM

Final Temp., OF

120

180

74.

Annual Usage, Gals.

$25,000,000$

180

$16,000,000$ 


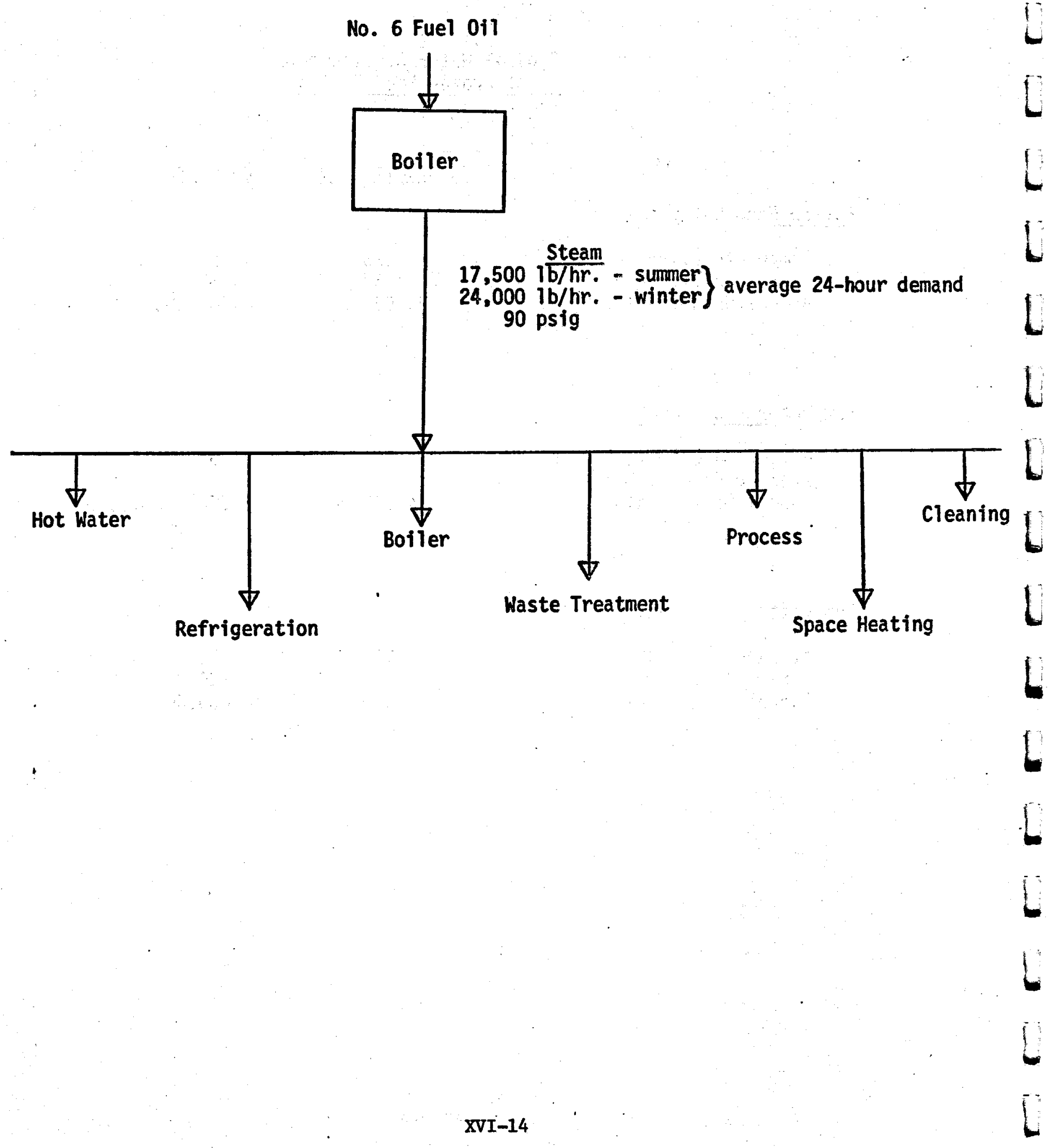




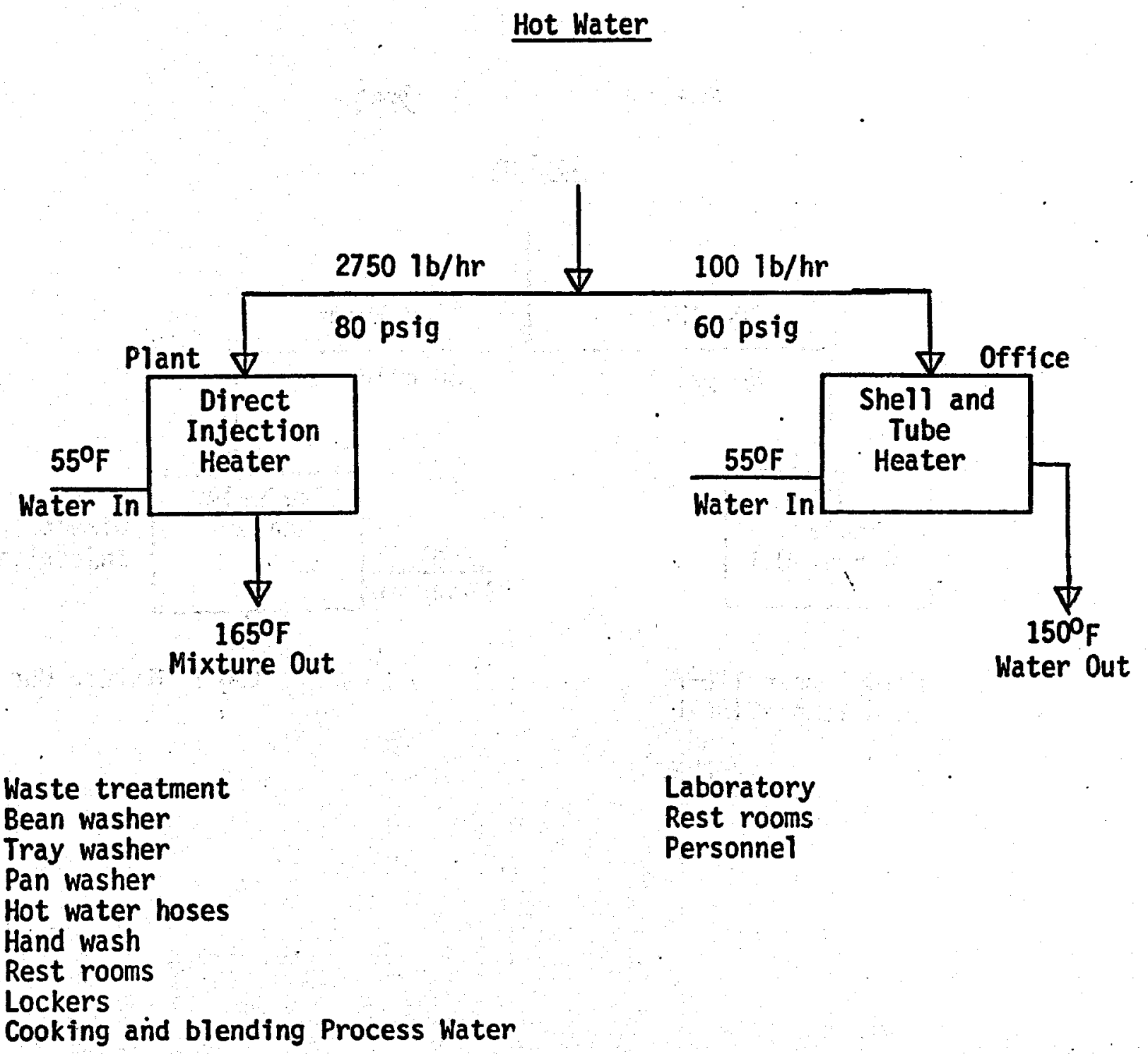




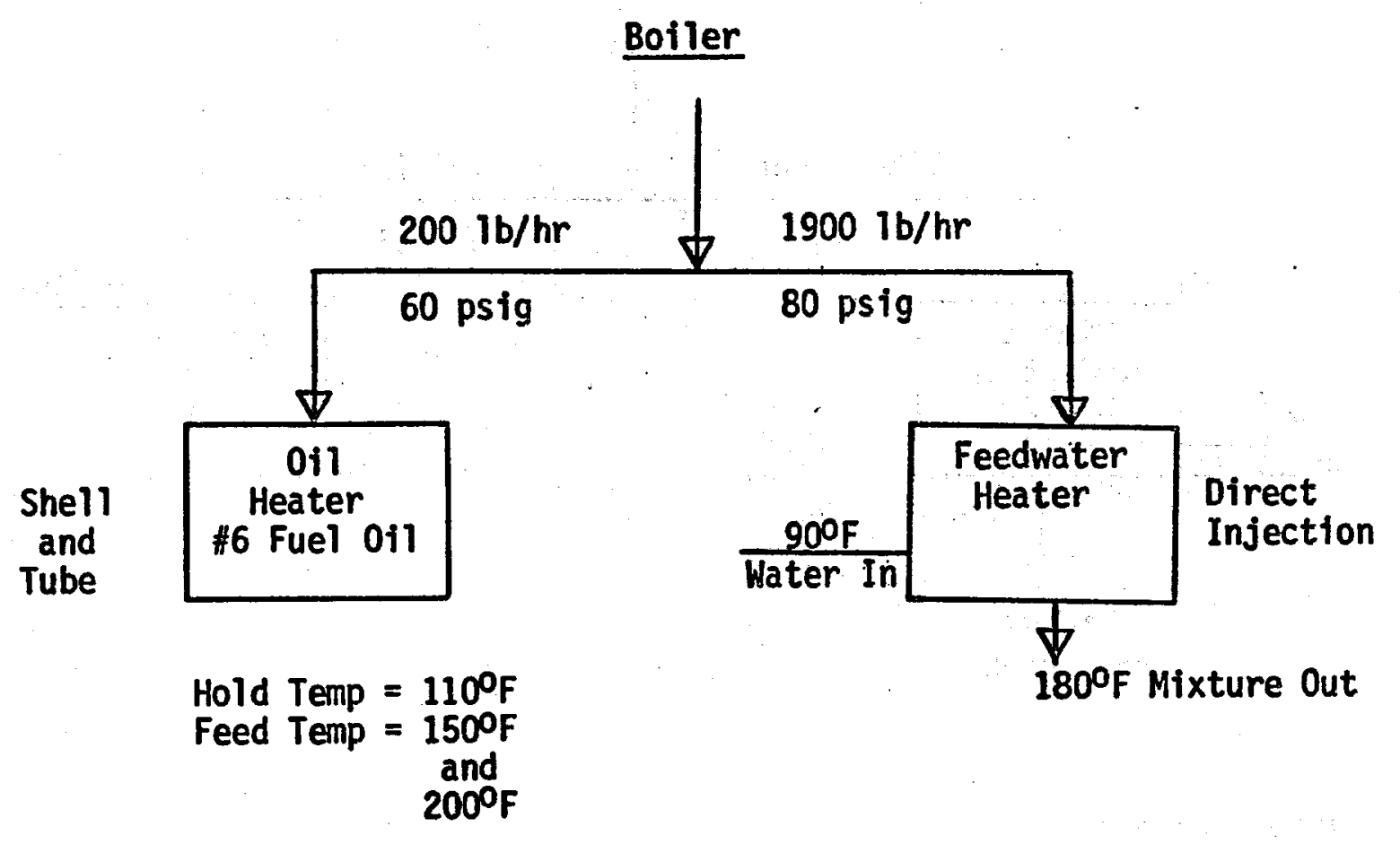




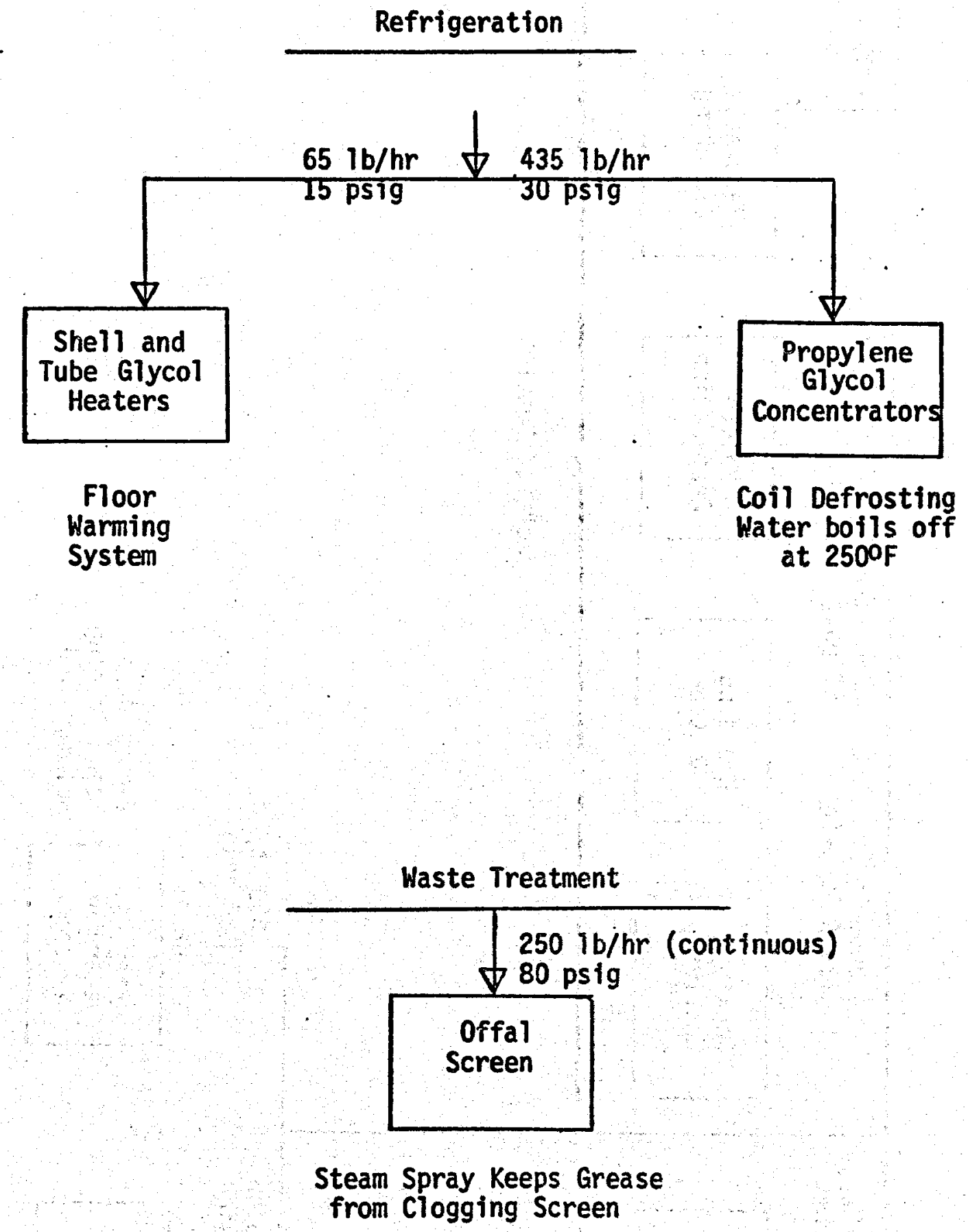


Process

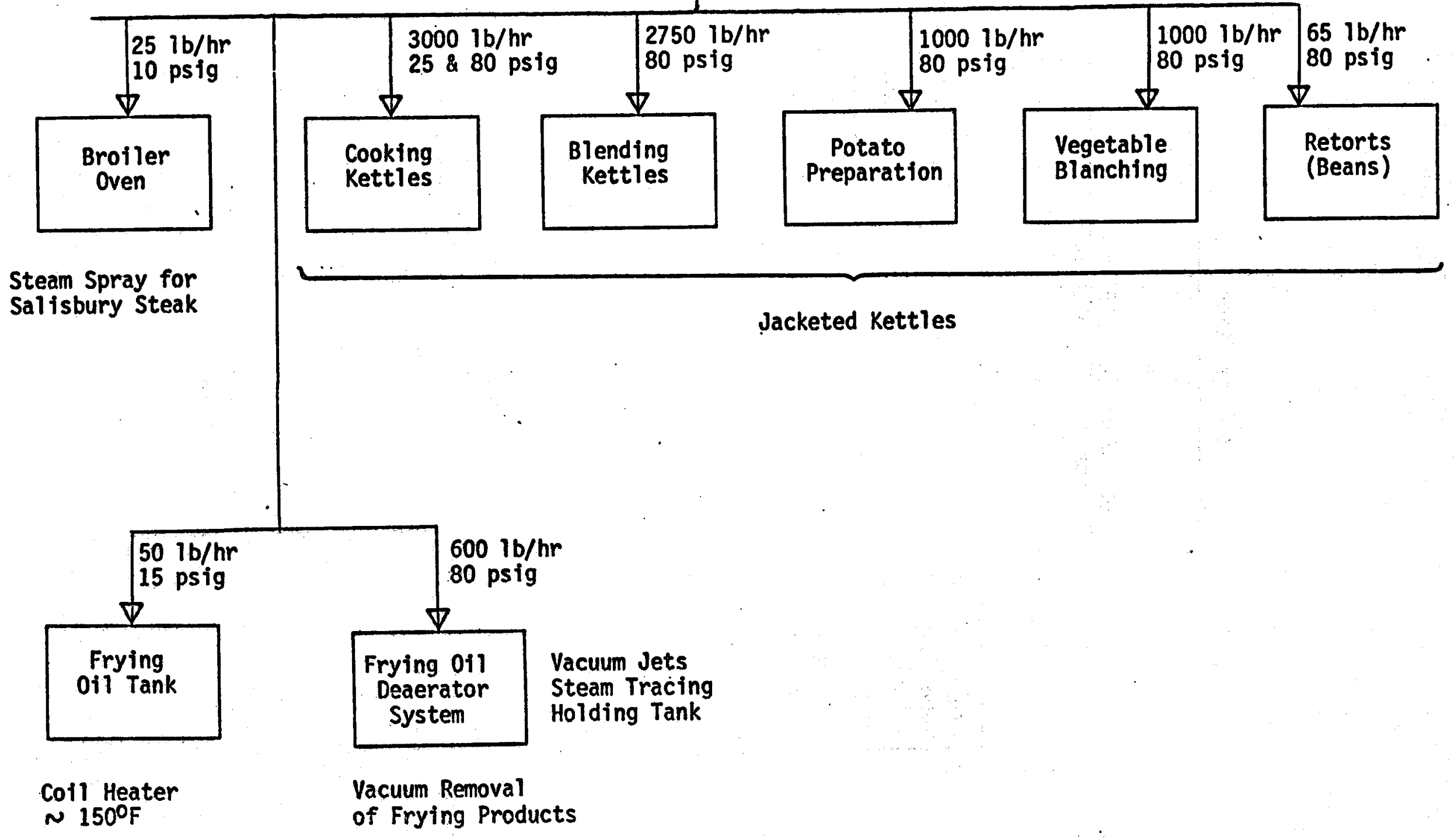




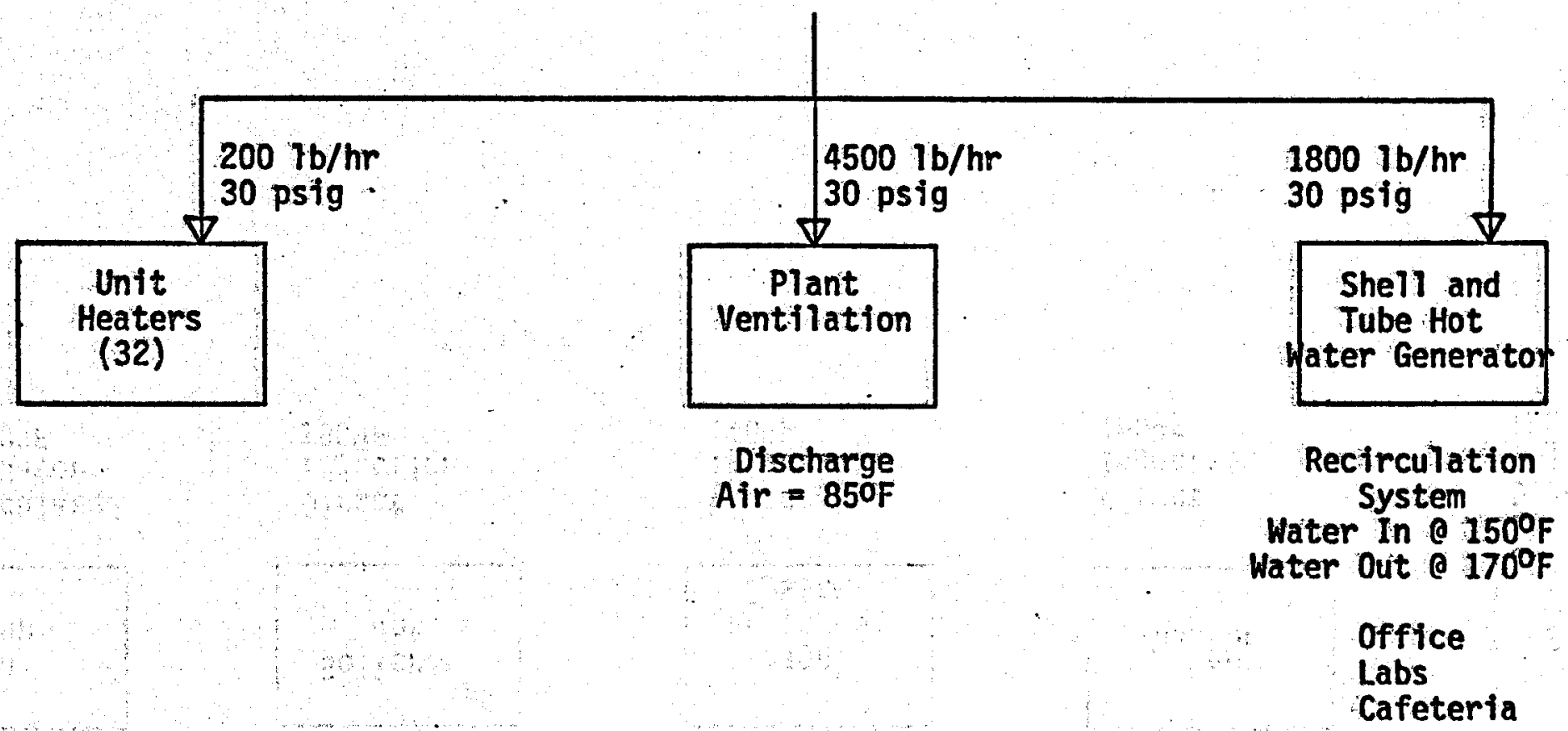




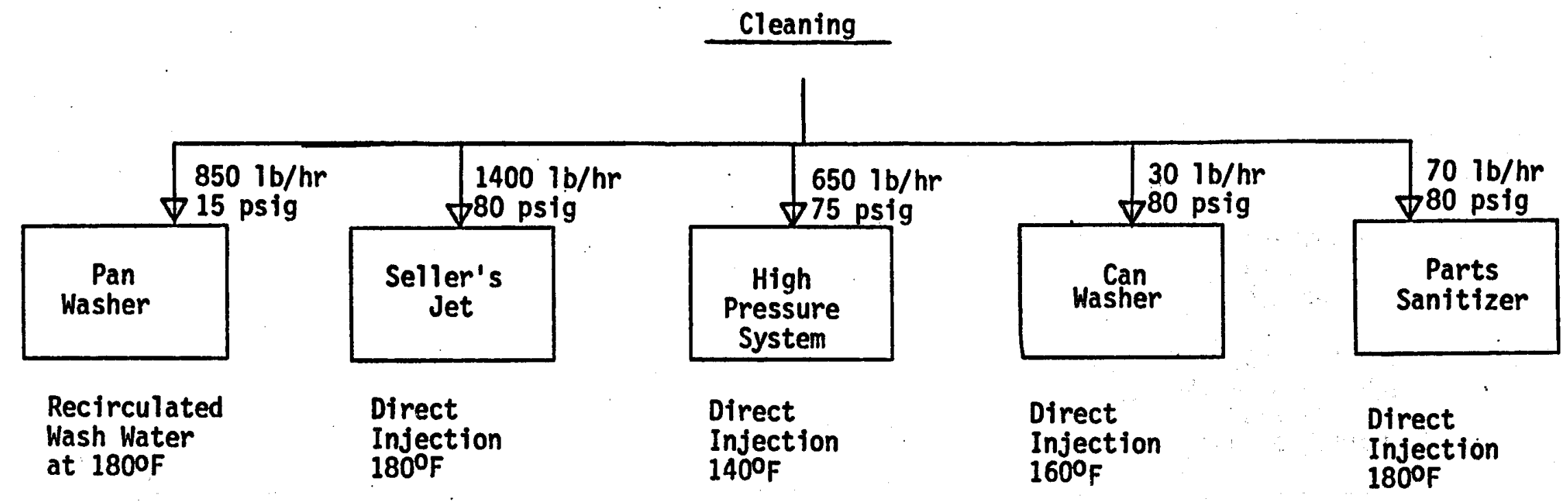

爻 
LNG Vaporization at Cove Point, Maryland using Geothermal Energy

\author{
by \\ A. B. Litchfield \\ Columbia LNG Corporation
}

XVII 


\section{LNG VAPORIZATION AT COVE POINT WITH GEOTHERMAL ENERGY}

Cove Point Receiving Terminal

Columbia LNG Corporation is a subsidiary of the Columbia Gas System which, together with the Consolidated Natural Gas Company, owns an LNG import terminal located on the Chesapeake Bay at Cove Point, Maryland. Cove Point is about fifty miles south of Washington D.C. The Cove Point terminal, which started operation in early 1978 , receives LNG from Algeria at an average baseload rate in excess of 600 MMScf of natural gas per day. This through put is roughly equal to $1 \%$ of the nation's natural gas consumption.

Ordinarily natural gas is transported through pipelines. However, since a transatlantic pipeline is beyond the state of the art at this time, it is necessary to utilize ships for transportation.

"LNG" is industry terminology for Liquefied Natural Gas and is simply natural gas that has been condensed to a liquid by lowering its temperature to $260^{\circ}$ below zero Fahrenheit. The natural gas is 1 iquefied to reduce its volume so that it can be transported at optimum cost. Six hundred cubic feet of natural gas at $60^{\circ} \mathrm{F}$ and atmospheric pressure occupies a volume of only one cubic foot when it is condensed to a liquid at $260^{\circ} \mathrm{F}$ below zero. Al though LNG is super cold, 
it is like any other liquid and can be pumped, stored and shipped in the same manner as water, oil, LPG, or other liquids. However, like other cyrogenic liquids such as liquid oxygen and nitrogen, it does require special materials of construction--aluminum, stainless and nickel steels--and all piping, storage tanks and equipment must be well insulated to maintain a low level of heat leak.

The natural gas produced from wells in North Africa's Sahara Desert is pipelined to the Mediterranean Coast where it is liquefied and loaded on to ocean going tankers. These tankers have a liquid capacity of 790,000 barrels, which is equivalent to about 2.6 billion cubic feet of natural gas. The voyage from Algeria to Cove Point requires about nine days. When the tankers arrive at Cove Point--roughly one tanker every four days--they are moored at one of two unloading piers. From these piers the LNG is unloaded at a rate of $50,000 \mathrm{gpm}$ through insulated stainless steel pipelines into four insulated 375,000 barrel storage tanks onshore. The pipelines pass through a 6000 foot tunnel which connects the pier to the shore. About 1000 feet inland, the tunnel terminates and the pipelines proceed another 3000 feet above ground into the storage tank area. From the storage tanks, LNG is pumped to a pressure of 1300 psig and passes through regasifiers where heat is added and the LNG again becomes conventional natural gas at a temperature of $40^{\circ} \mathrm{F}$. The high pressure gas is then transported through a 36 " underground pipeline to a point in 
Loudoun County, Virginia, near the Dulles Airport. At this point, the gas enters the regular gas transmission systems of Columbia and Consolidated. Much of Columbia's share of the gas flows directly to markets in Baltimore and Washington.

\section{Application of Geothermal Energy}

Cove Point generates its own power with gas fired turbines. Waste heat from these turbines is utilized to regasify approximately $15 \%$ of the LNG throughput. However, most of the regasification is accomplished by burning gas to provide heat. Recently Columbia LNG decided to investigate the possibility of supplying the regasification heat with geothermal energy. After many discussions with various organizations involved in the east coast geothermal effort, it is now believed that Cove Point would be an ideal application for east coast geothermal because of its ability to utilize low temperature water in the range of $100-125^{\circ} \mathrm{F}$ and extract heat down to a level of 40 or $50^{\circ} \mathrm{F}$. This can be done because the heat transfer in the regasifiers is at a very low level, i.e., raising the LNG temperature from $260^{\circ} \mathrm{F}$ below zero to only $40^{\circ} \mathrm{F}$ above zero.

Utilizing conventional shell and tube exchangers with an intermediate fluid, geothermal water could be used to regasify up to 400 million cubic feet per day. The gas now being used as fuel for this amount of regasification is approximately 2 billion cubic feet per year with a current value of over $\$ 5$ million. This quantity of gas is equivalent 
to almost 400,000 barrels of oil. If geothermal water is

available in sufficient quantities, then, assuming a 20-year supply at $125^{\circ} \mathrm{F}$ with reinjection at $50^{\circ} \mathrm{F}, 400 \mathrm{gpm}$ per well, 20 production and 20 reinjection we1ls and approximately 2000 feet of pumping head required, a geothermal installation would pay out in six or seven years based on the current fuel gas price at Cove Point. This payout would no doubt improve with time since the price of fuel will continue to escalate while the cost of producing geothermal water should remain relatively constant because it is primarily capital intensive with operating costs contributing only a small part of the total. Figure 1 shows an aerial photo of the Cove Point LNG receiving terminal. Columbia LNG owns just over 1000 acres, of which 50 acres are occupied by the terminal. The dotted line superimposed on the photo represents the property boundaries. At the present time it is hoped all the production and reinjection wells could be constructed within the property. However, in order to obtain necessary well spacing they may have to extend beyond these boundaries, perhaps even into the bay area.

There are a number of questions that need to be answered. The two most important are whether geothermal water exists under our property, and if so bow much? In order to determine this, several things will have to be done:

(1) Drilling of a 1000 foot test well to verify the existence of adequate thermal-gradient; 

(2) Drilling of a 3000 foot well to verify the presence of hot water, temperature, pressure, water quality, and performing preliminary flow tests;

(3) Construction of a pilot plant involving the drilling of a second 3000 foot water well and installing the necessary equipment for vaporizing approximately 20 MMcfd of LNG.

Current plans are to submit a formal proposal to our management based on this type of a phased program. We believe the possibility exists for the successful development of a geothermal energy project at the Cove Point receiving terminal and are very hopeful that this important resource can be developed to its full potential. 


\title{
Department of Defense
}

Geothermal Development Program

\author{
by \\ Dr. Carl F. Austin* \\ Thomas A. Ladd \\ Naval Facilities Engineering Command
}

5

I

$E$

1

\section{XVIII}

*Authors could not attend meeting but forwarded this summary for inclusion in the minutes. 
DOD GEOTHERMAL DEVELOPMENT PROGRAM

By

Dr. Carl F. Austin

Mr. Thomas A. Ladd

The objective of the Navy's geothermal program is to provide a technical, economic and institutional assessment of geothermal resources which may exist on Navy lands throughout the world in order that these resources may be beneficially utilized by the Navy and that, to the extent possible, energy driven encroachment pressure is minimized. The major thrust of this program is to promote compatible joint use of the lands involved so as to assure continuance of mission related activities. A master plan for the Navy's investigation and subsequent.exploitation of geothermal resources is in the final stages of preparation, and should be ready for dissemination by the end of 1979. Current initiatives in the geothermal program are centered at the Coso Hot Springs area at the NWC China Lake, evaluation of possible space heating applications at NAS Fallon, Nevada, continuing research at Adak, Alaska, and preliminary data gathering/literature search efforts for potential resources such as on the island of Oahu, Hawail, and on the Atlantic coastal plain and at selected foreign bases.

A Request for Technical Proposal (RFTP) was issued by Western Division, Naval Facilities Engineering Command on 2 May 1979 for the 30-year development of possible geothermal resources underlying $41 / 2$ square miles of Navy fee-acquired land in the Coso KGRA. If the resource proves viable, the contractor will build, own, operate, and maintain one or more power plants and distribution lines as required to provide electric power to NWC and other West Coast Navy activities up to an initial maximum of 75 MWe. All development will be accomplished at no capital cost to the government, and Navy will retain ownership of the resource. The contractor will be required to adhere to certain operating constraints designed to ensure that any exploration, development or production of geothermal resources is done safely and does not conflict with performance of the mission of NwC. A proposer, whose submission was found technically competent, has been asked to submit pricing information as the second step in this two-part procurement.

NAS Fallon and its associated ranges have good geothermal potential. It has been given second priority for development and active exploration is currently underway. A well drilled at NAS Fallon in 1942 is capable of producing $130^{\circ} \mathrm{F}$ water from a depth of 1700 feet. Water of this temperature is suitable for space heating. Just to the southeast of the Base, a 163 foot well is flowing $170^{\circ} \mathrm{F}$ water. Four 500 foot thermal gradient holes have been drilled which support a model whereby water suitable for space heating could be present in the southeast corner of the Base at depths of a few thousand feet. Water and mercury geochemical studies and satellite photo interpretation also support the model, indicate a second favorable area on the northern part of the station, and indicate a resource suitable for electric power generation could be present. This is also supported by oil and geothermal companies leasing the lands surrounding the Base and conducting active exploration. Additional thermal gradient holes are being drilled 
and mercury geochemical studies are continuing. Range Bravo 19 has a surface manifestation of geothermal resources just off of its northeast corner -- Lee Hot Springs. Oxygeothermal (Oxidental Petroleum) has leased all of the lands bordering the range to the north and has applied for leases of lands to the east. They have completed one 3000 foot exploratory hole. Three thermal gradient holes, mercury and water geochemistry, and lineament studies done by the Navy indicate good potential of a resource suitable for electric power production on Bravo 19. A contract for two additional thermal gradient holes will be let this fiscal year. Range Bravo 16 has favorable mercury geochemistry and geologic structures. A contract for five thermal gradient holes to test this area has been let.

The next logical phase on the Atlantic coastal plain will be the identification of a heating load requirement for a specific location. From this the temperature and flow requirements for a geothermal space heating system can be determined. That knowledge is vital to identify the resource requirement that we are searching for. Tentatively the Navy is planning on doing a study of the space heating requirements/systems at the Naval Base, Norfolk to determine its susceptibility for conversion to a geothermal heat source. In addition, the institutional/legal problems associated with using the deep aquifer at Norfolk for heating and disposal of the fluids must be studied and resolved. Once the above has been successfully completed, then Navy would undertake a drilling program to prove the resource. Our plans had included doing feasibility and legal studies at Norfolk during FY80 but recent Congressional budgetary cuts may prevent us from doing so. 

is shown in Fig. XIX-11. Total energy requirements are shown in Fig. XIX-12 for each sector and each resource area. The figures shown on SC and GA are rough initial estimates. Fig. XIX-13 shows the same data in terms of equivalent barrels of oil. If $100 \%$ market penetration were achieved immediately, the equivalent of 58,500 barrels of oll per day could be displaced.

The Geothermal Resource Interactive Temporal simulation (GRITS) model (FIg. XIX-14) is a flexible measy-to-use, interactive computer model that permits both cost and revenue streams to be estimated for some project lifetime The model allows the inclusion of a wide range of resource and economic conditions, many of which may be varied over the valuation period of the project. Such a model is an improvement over average cost mode1s in that 1) annual differences in, resource, user, and economic conditions can be accounted for, 2) the effects of increasing market penetration can be annua $11 \mathrm{y}$ assessed, rather than having a maximum value assumed for the entire evaluation period, and 3) the reduction in real dollar costs due to Inflation is easily shown. Some of the GRITS input variables for resource, user, economic conditions are, shown $1 \mathrm{n}$ Fig. XIX-15, 16 and 17, respectively. Fig. XIX-18 shows some of the outputs from GRITS. 
In summary (Fig. $X I X-19)$, the market assessment is finished in the four northern ACP resource areas and reports are being issued. The capability for modeling the economics of geothermal energy has been developed and is avallable to interested users. A market penetration methodology is under development. Efforts on market definition are planned for South Carolina and Georgia. 
OUTLINE

离

- INTRODUCTION TO GEMS

- MARKET DEFINITION RESULTS

- ECONOMIC MODELING (GRITS) 
th

\section{GEOTHERMAL ENERGY MARKET STUDY (GEMS)}

\section{OBJECTIVES:}

- DETERMINE APPLICATIONS FOR GEOTHERMAL ENERGY IN:

SOUTHEASTERN NEW JERSEY

DELMARVA PENINSULA

NORFOLK, VA. AREA

EASTERN NORTH CAROLINA

- RECOMMEND BEST RESOURCE AREA ON BASIS OF MARKET POTENTIAL

- ASSIST DOE/DGE AND VPI\&SU IN SITE SELECTION OF DEEP WELL

- PREPARE FINAL REPORT 
THE FOUR AREAS OF INTEREST IN THE ATLANTIC COASTAL PLAIN.

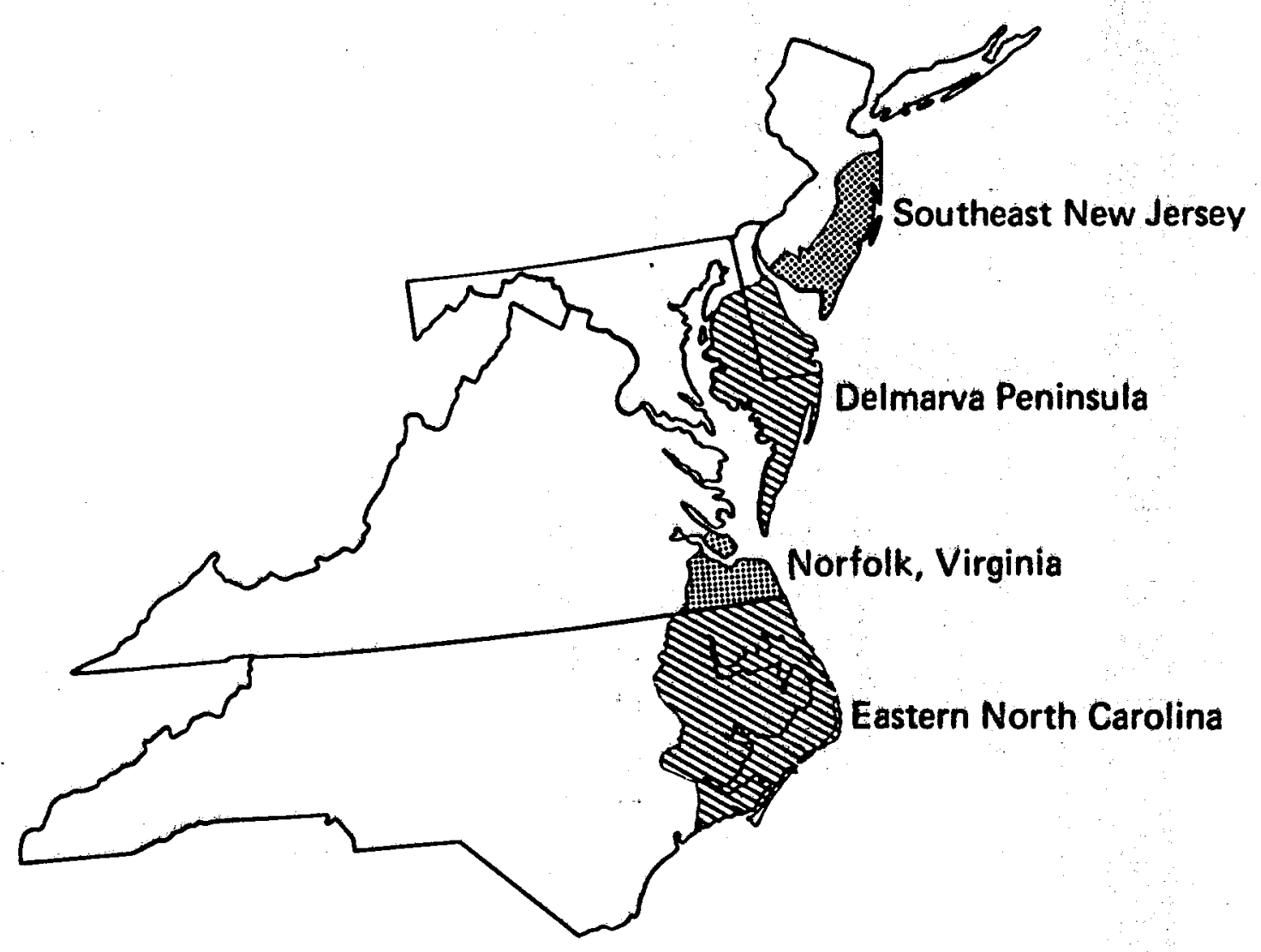



$r$
$r$

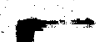
$-$
C
$\Leftrightarrow$
$F$
$r E r E$
$E r$

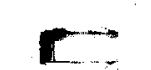
$r$

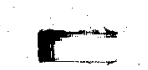
c

GEOTHERMAL ENERG Y MARKET STUDY (GEMS)

(CONTINUED)

TASKS:

- MARKET DEFINITION:

ENERGY USE SURVEY

ENERGY USE ANALYSES

ENGINEERING ANALYSES

- MARKET PENETRATION:

PRICE PROJECTIONS OF CONVENTIONAL FUELS

GEOTHERMAL ENERGY COSTS

MARKET PENETRATION 


\section{GEOTHERMAL APPLICATIONS}

- RESIDENTIAL SPACE CONDITIONING (HEATING AND AIR CONDITIONING) AND WATER HEATING

- COMMERCIAL SPACE CONDITIONING AND WATER HEATING

- MILITARY SPACE CONDITIONING AND WATER HEATING

- AGRICULTURE

- CROP DRYING

- CORN, TOBACCO, PEANUTS, SOY BEANS

- POULTRY

- BROODING

- SPACE HEATING

- WATER HEATING

- FROST PROTECTION

- MANUFACTURING INDUSTRIES

- FOOD

- TOBACCO

- TEXTILES

- LUMBER

- PULP AND PAPER

- CHEMICALS 


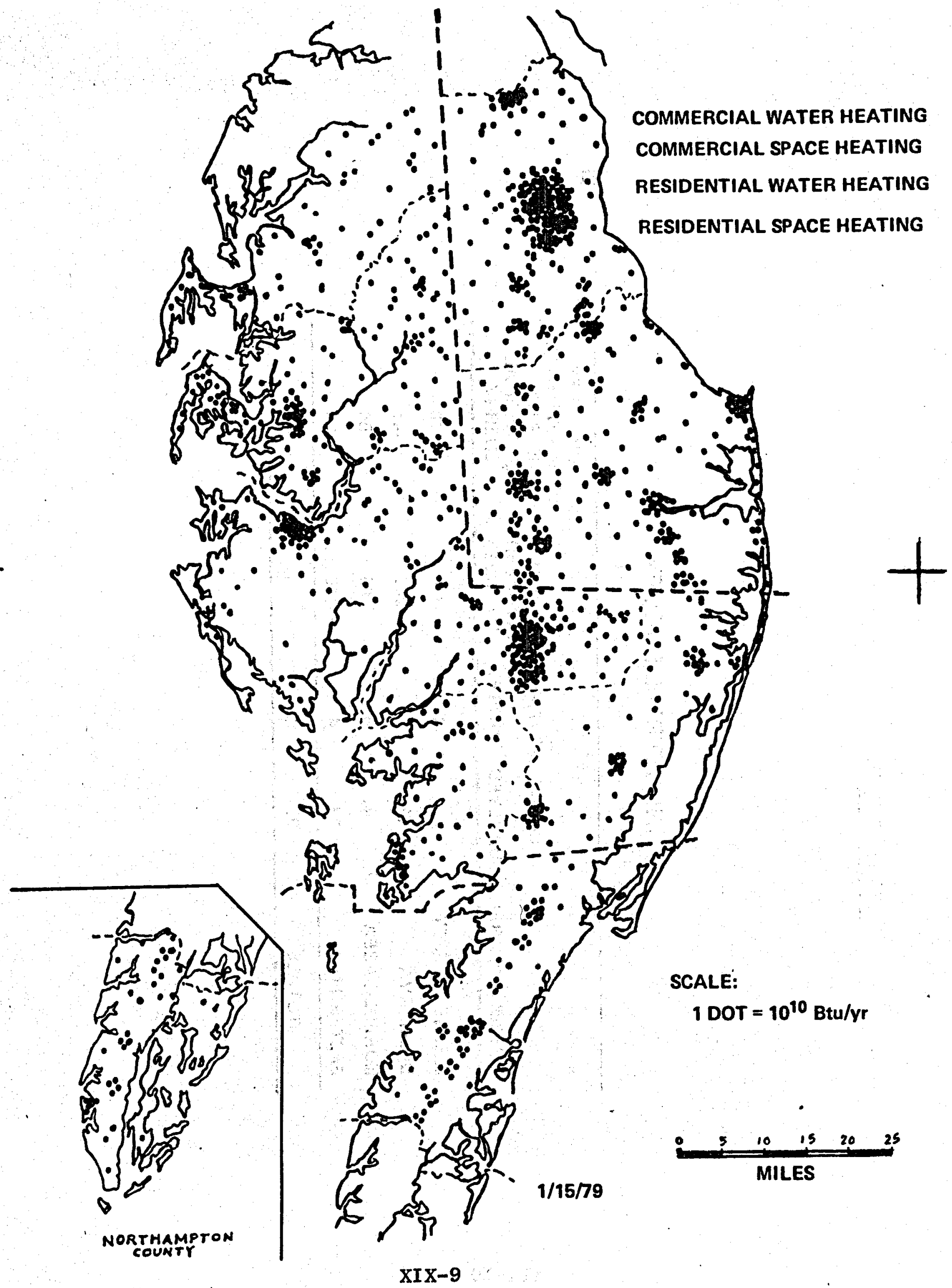


INDUSTRIAL SURVEY

\begin{tabular}{lrrrrr}
\hline & \multicolumn{2}{c}{ COUNTIES/CITIES } & $\begin{array}{c}\text { COMPANIES } \\
\text { COMPANIES } \\
\text { INVOLVED } \\
\text { RESOURCE AREA }\end{array}$ & $\begin{array}{c}\text { WITH POTENTIAL } \\
\text { USES FOR } \\
\text { GEOTHERMAL } \\
\text { ENERGY }\end{array}$ \\
\hline S. E. NEW JERSEY & 5 & 1 & 124 & 48 \\
DELMARVA & 11 & 2 & 240 & 146 \\
NORFOLK AREA & 4 & 5 & 106 & 54 \\
EASTERN N.C. & 13 & 4 & $\sim 140$ & $\sim 73$ \\
\hline \multicolumn{1}{c}{ TOTALS } & 33 & 12 & $\sim 610$ & $\sim 321$ \\
\hline
\end{tabular}

量

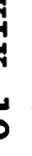




\section{INDUSTRIAL MARKETS FOR GEOTHERMAL ENERGY} ON THE DELMARVA PENINSULA
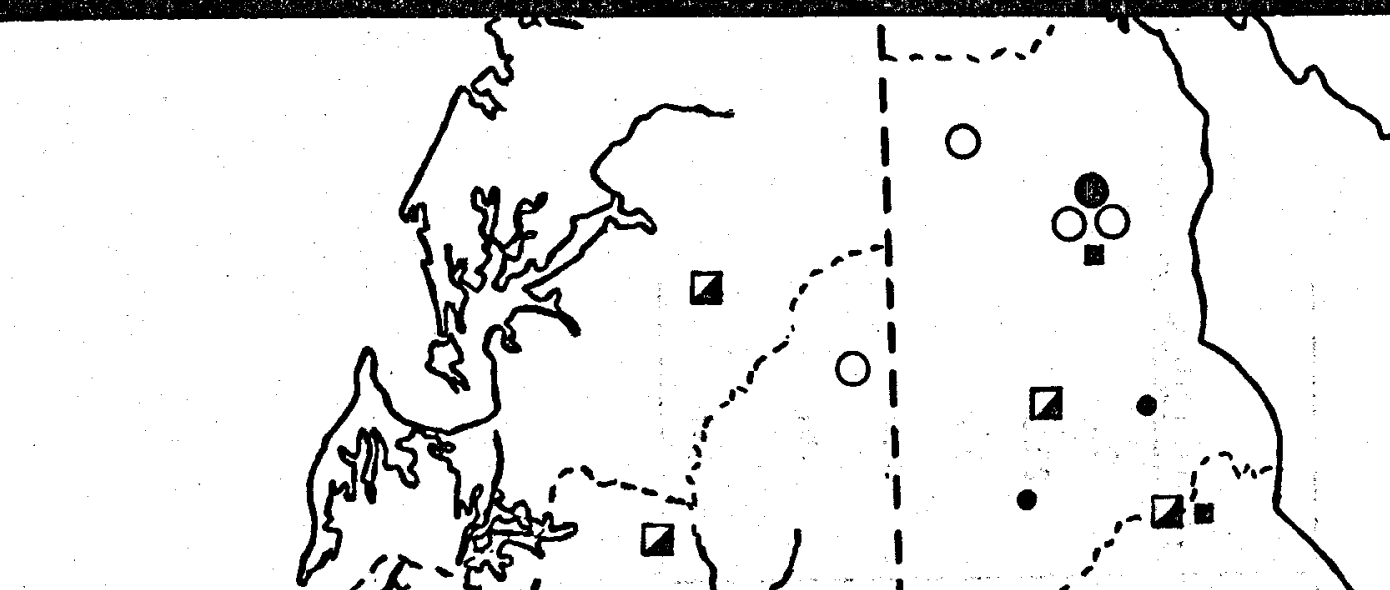

L

L.

$\frac{5 \quad 10 \quad 15 \quad 20 \quad 25}{\text { MILES }}$
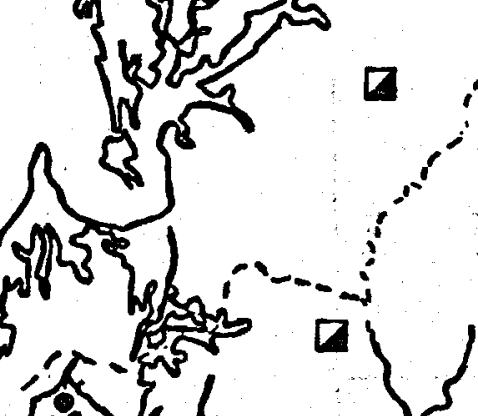

$---1$

$Q$
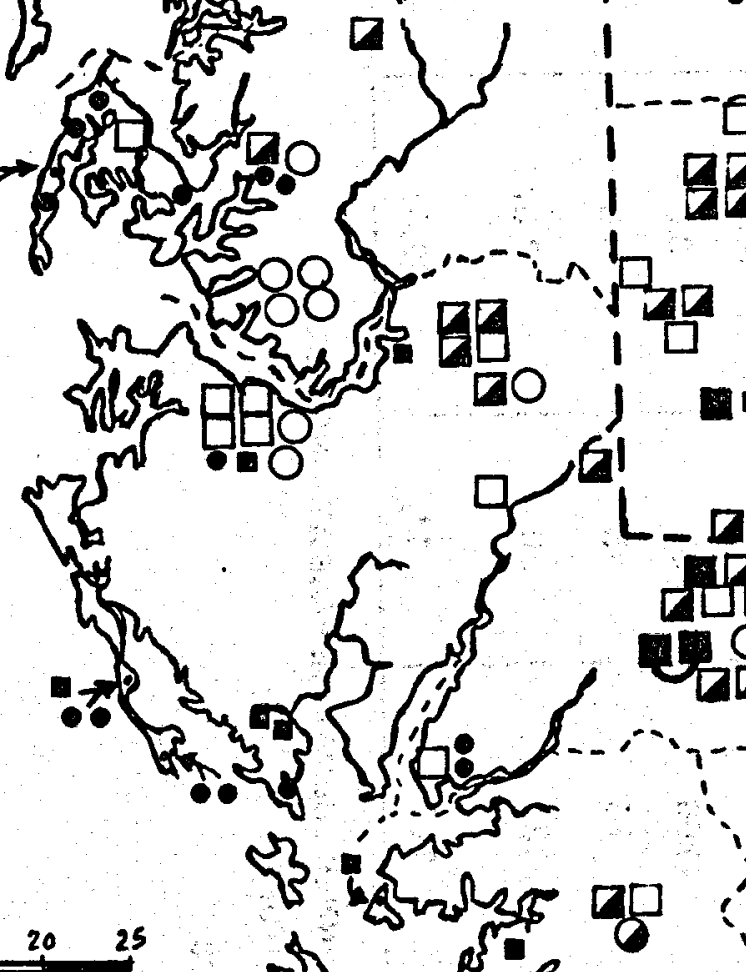

$\int^{1} \int^{1}$

0

of

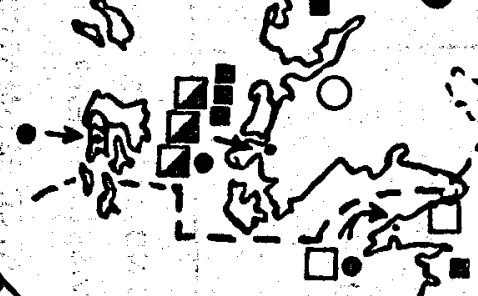

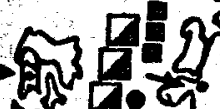

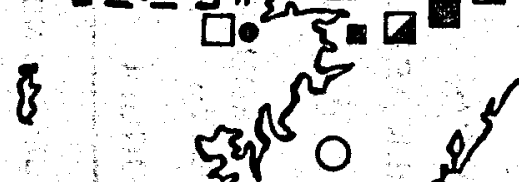

THERMAL REQUIREMENTS BELOW
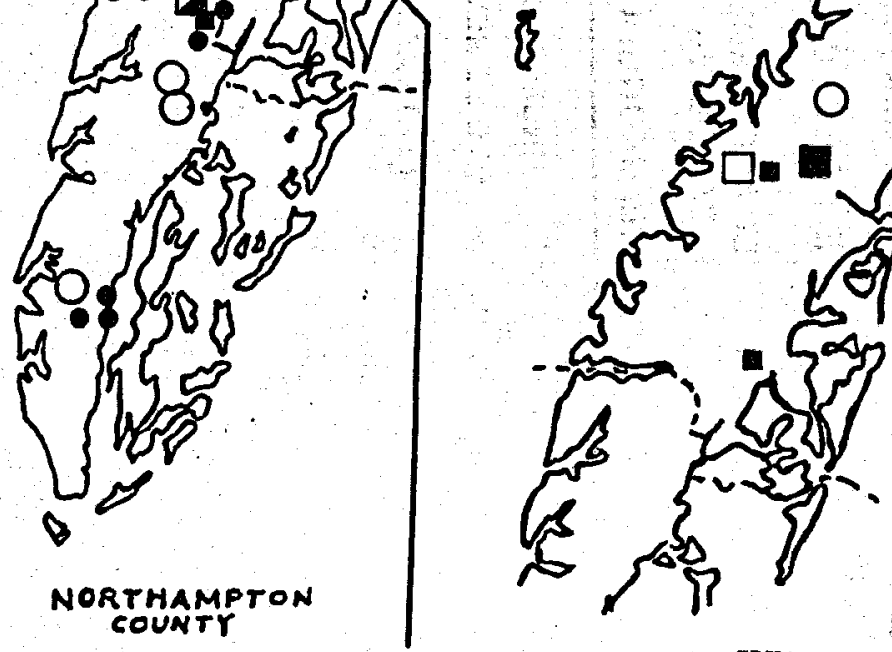
$250^{\circ} \mathrm{F}$ (BTU/YR)

ESTIMATED ACTUAL

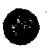

USAGE

$\quad 0.5-1.0 \times 10^{11}$

0

․ $1.5 \times 10^{10}$

O

$1.10 \times 10^{9}$ 
CURRENT POTENTIAL MARKETS FOR GEOTHERMAL ENERGY (1011 BTU/YR)

\begin{tabular}{l|c|c|c|c}
\hline $\begin{array}{c}\text { RESOURCE } \\
\text { AREA }\end{array}$ & $\begin{array}{c}\text { SESIDENTIAL } \\
\text { AND } \\
\text { COMMERCIAL }\end{array}$ & MILITARY & AGRICULTURE & INDUSTRIAL \\
\hline S.E. NEW JERSEY & 290 & 25 & 0.2 & 9.3 \\
DELMARVA & 125 & 8 & 14.5 & 23.2 \\
NORFOLK AREA & 200 & 97 & 0.5 & 9.1 \\
E. NORTH CAROLINA & 78 & 15 & 9.5 & 9.09 \\
COASTAL SOUTH & 131 & 30 & $7.6 \dagger$ & $\sim 18 t$ \\
CAROLINA & 125 & $1 *$ & $12.0 \dagger$ & $\sim 44 t$ \\
S.E. GEORGIA & & & & \\
\hline
\end{tabular}

"INCLUDES NO DATA ON PLANNED SUBMARINE BASE AT KING'S BAY II TO BE REVISED IN NEAR FUTURE

TEXTRAPOLATED ESTIMATES 
CURRENT POTENTIAL MARKETS FOR GEOTHERMAL ENERGY $10^{6}$ EQUIVALENT BARRELS OF OIL: $\left(1 \mathrm{bbl}=6 \times 10^{6} \mathrm{Btu} / \mathrm{yr}\right)$

\begin{tabular}{|c|c|c|c|c|c|}
\hline $\begin{array}{c}\text { RESOURCE } \\
\text { AREA }\end{array}$ & $\begin{array}{l}\text { RESIDENTIAL } \\
\text { AND } \\
\text { COMMERCIAL }\end{array}$ & MILITARY & AGRICULTURE & INDUSTRIAL & TOTAL \\
\hline S.E. NEW JERSEY & 4.833 & 0.417 & 0.003 & 0.157 & 5.410 \\
\hline DELMARVA & 2.083 & 0.133 & 0.242 & 0.387 & 2.845 \\
\hline NORFOLK AREA & 3.333 & 1.617 & 0.008 & 0.152 & 5.110 \\
\hline E. NORTH CAROLINA & 1.300 & 0.250 & 0.158 & 0.150 & 1.858 \\
\hline $\begin{array}{l}\text { COASTAL SOUTH } \\
\text { CAROLINA }\end{array}$ & 2.183 & 0.500 & 0.127 & 0.300 & 3.110 \\
\hline S.E. GEORGIA & 2.083 & 0.017 & 0.200 & 0.733 & 3.033 \\
\hline TOTAL & 15.815 & 2.934 & 0.738 & 1.879 & 21.366* \\
\hline
\end{tabular}

"EQuivalent TO ABOUT 58,500 BARRELS OF OIL PER DAY 


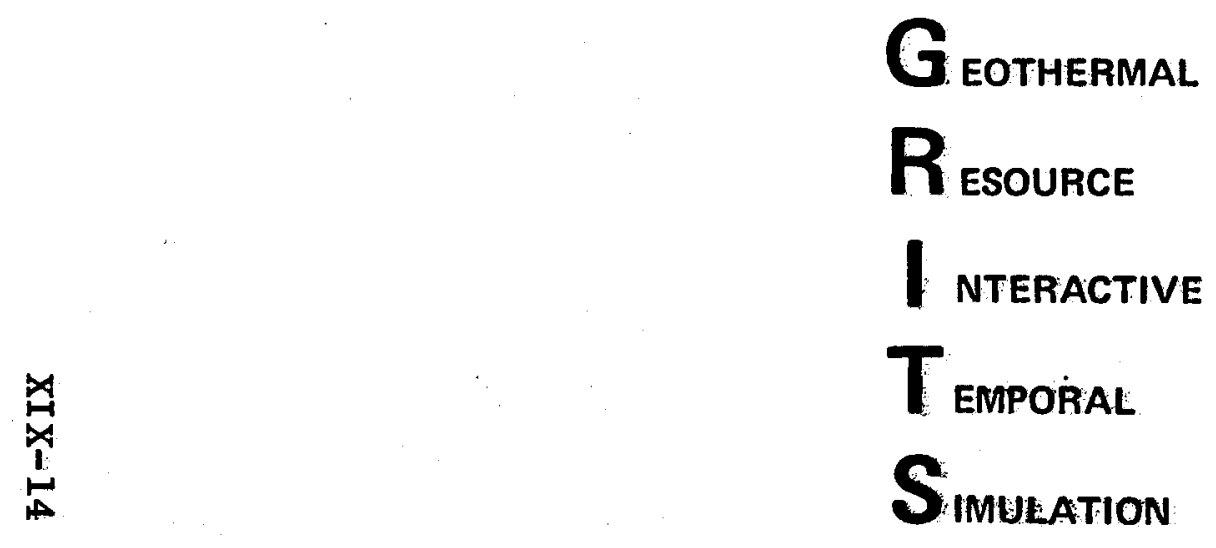

- interactive computer model

- eSTIMATE COST AND REVENUE STREAMS 


\section{GRITS INPUTS} RESOURCE VARIABLES

- COST AND DURATION OF RESOURCE EXPLORATION AND DEVELOPMENT

- WELLS - NUMBER, DEPTH, NEED FOR REINJECTION

- FLOW RATE

- TEMPERATURE

VARIABLE WITH TIME

- DRAWDOWN

- TRANSMISSION DISTANCE TO USERS 


\section{GRITS INPUTS}

USER VARIABLES

- CATEgORY

- BUILDING TYPE

- COMMERCIAL FLOOR SPACE AND

NUMBER OF BUILDINGS

- INDUSTRIAL UTILIZATION FACTOR

- WEATHER DATA

- DESIGN TEMPERATURE

- DISTRIBUTION SYSTEM 



\section{GRITS OUTPUTS}

- ANNUALIZED COSTS FOR SYSTEM COMPONENTS

- ANNUAL ENERGY SUMMARY

NUMBER OF CUSTOMERS

ENERGY SALES

PEAKING ENERGY NEEDS

PUIMPING ENERGY USED

- AVERAGE ENERGY COST (\$ PER MILLION BTU)

- NET PRESENT VALUE OF DISCOUNTED COST AND REVENUE STREAMS 



\title{
Comparison of Potential
}

\section{Geothermal Resources}

\section{Eastern United States}

\author{
by \\ R. F. Meier \\ Applied Physics Laboratory \\ The Johns Hopkins University
}

\section{$X X$}


COMPARATIVE ANALYSIS OF EASTERN GEOTHERMAL AREAS*

ROBERT F, MEIER

The APPLIED Physics LABORATORY (JHU/APL) hAS DEVELOPED A METHOD FOR COMPARING GEOGRAPHIC AREAS IN THE EASTERN UNITED STATES WITH RESPECT TO THEIR GEOTHERMAL (HYDROTHERMAL) POTENTIAL. THIS WORK IS PART OF THE LABORATORY'S EFFORT TO SUPPORT THE DEPARTMENT OF ENERGY IN FOSTERING THE COMMERCIAL DEVELOPMENT OF LOW TO MODERATE TEMPERATURE RESOURCES.

THE PROCEDURE WHICH I WILL DESCRIBE BRIEFLY IS A FAIRLY STRAIGHTFORWARD, SYSTEMMATIC WAY TO:

(A) COORDINATE RESULTS OF DOE AND STATE-COUPLED PROGRAMS TO TARGET, CONFIRM AND ASSESS GEOTHERMAL RESOURCES AND HENCE INDICATE DIRECTION FOR FUTURE EFFORTS, AND

(B) EVALUATE ALTERNATE STRATEGIES FOR ALLOCATING FEDERAL RESOURCES TO PROGRAMS INTENDED TO STIMULATE COMMERCIALIZATION.

OUR RESOURCE AREA EVALUATION METHOD COMBINES GEOLOGIC, ENGINEERING AND ECONOMIC FACTORS AT THE COUNTY LEVEL WHERE SUCH DATA ARE AVAILABLE. AS NEW OR BETTER DATA ARE AVAILABLE THE PROSPECTIVE RESOURCE AREAS CAN BE REASSESSED READILY. THIS CAPABILITY REFLECTS THE ATTITUDE THAT GEOTHERMAL RESOURCE DATA WILL NEVER BE ACCURATE ENOUGH AND COMPLETE ENOUGH TO DEFINE, ONCE AND FOR ALL, THE STRATEGY FOR COMMERCIALIZATION.

*THe MATER IAL PRESENTED HERE IS A SUMMARY OF THE APL REPORT: EVALUATION OF POTENTIAL RESOURCE AREAS, F. 0, MitCHELL, APL/JHU QM-79-163/GT, JULY 1979. 
THE DATA WHICH WE hAVE COLLECTED TO ILLUSTRATE the ASSESSMENT METHOD COVER 226 COUNTIES IN 16 STATES SHOWN IN THE FiguRE 1. THE SHADED AREAS WERE EXCLUDED, PRINCIPALLY, BECAUSE OF LOW gRADIENTS AND SHallow basements, SOME coastal REgions (Maryland Delaware and parts of Virginia and North (arolina) were excluded ALSO BECAUSE OF THE ESTABLISHED DOE DRILLING PROGRAM IN THESE AREAS.

Figure 2 SHOWS THE COUNTIES OF ONE STATE THAT EXHIBIT A GRADIENT GREATER THAN $1.6^{\circ} \mathrm{F} / 100 \mathrm{FT}$. AND DEPTH TO BASEMENT GREATER THAN 1000 FEET, ARBITRARILY CHOSEN VALUES FOR OUR ILLUSTRATION.

FIGURE 3 SHOWS THE TYPES OF DATA COLLECTED OR DERIVED FOR EACH CANDIDATE COUNTY, DEPTH TO BASEMENT IS LISTED IN THOUSANDS OF FEET. THESE DATA WERE OBTAINED FROM USGS AND AAPG (AMERICAN Association of Petroleum Geologists) maps,

TOWNS, AS THE TERM IS USED HERE, ARE INCORPORATED PLACES WITH POPULATION BETWEEN 500 AND 20,000; CITIES ARE OVER 20,000. THESE LINES OF DISTINCTION, JUST AS GRADIENT OR MINIMUM DEPTH TO . basement, are defined by the evaluator. Data are from the Census BUREAU.

Heating degree days were obtained from the National OCEANic AND ATMOSPHERIC ADMINISTRATION.

Value added data were obtained from the Census Bureau's "City and County Data Book."

THE REMAINING ENTRIES ARE DERIVED. ITEMS. 17 RESOURCE TEMPERATURES ARE ESTIMATED AS THE SUM OF NORMAL GROUND TEMPERATURE (ASSUMED TO BE $55^{\circ} \mathrm{F}$ FOR ALL SITES) PLUS THE 
GRADIENT INCREASE TO 75\% OF BASEMENT (ARBITRARILY SELECTED).

EXTRACTABLE HEAT IS CALCULATED ON A SPENT-WATER TEMPERATURE OF $100 \mathrm{~F}$. THIS NUMBER IS NOT USED AT PRESENT BUT IS RETAINED FOR THE TIME THAT WATER AVAILABILITY AND WELL FLOW RATES CAN BE ESTIMATED,

THE COST COLUMN REPRESENTS DRILLING AND CASING AN 8 INCH Well. The costs are calculated from an equation fitting Milora AND TESTER DATA QUITE ADEQUATELY FOR DEPTHS LESS THAN 10,000 FEET. ENERGY USE DATA FOR THE RESIDENTIAL, COMMERCIAL AND INDUSTRIAL SECTORS WERE TAKEN FROM THE GEOTHERMAL FACT SHEETS PREPARED BY APL FOR EACH OF THE EASTERN STATES. PURCHASED ELECTRICAL ENERGY WAS EXCLUDED, HOWEVER, UNDER THE ASSUMPTION THAT OUR EASTERN RESOURCES WILL NOT REPLACE ANY ELECTRICITY USE.

RES IDENTIAL AND COMMERCIAL USES OF ENERGY IN EACH STATE WERE APPORTIONED TO THE COUNTIES ON THE BASIS OF POPULATION.

INDUSTRIAL ENERGY USE IN THE STATE WAS APPORTIONED TO THE COUNTIES ON THE BASIS OF VALUE ADDED IN MANUFACTURING. WHEN VALUE ADDED WAS NOT AVAILABLE WE APPORTIONED INDUSTIRAL USE ON THE BASIS OF THE NUMBER OF MANUFACTURING ESTABLISHMENTS.

SO MUCH FOR DATA SPECIFICATION. IT NOW REMAINS TO SELECT THE BEST, SECOND BEST, ETC, ROWS FROM THIS MATRIX. IF THERE WERE NATURAL BASES FOR COMPARING GEOTHERMAL PROSPECTS WE COULD TREAT THE DATA SET AS A MATRIX OF UTILITIES AND MULTIPLY IT BY A COLUMN MATRIX EXPRESSING OUR PREFERENCE FOR OR WEIGHTING OF COLUMN HEADINGS. 
HOWEVER, TRANSFORMING THESE ENTRIES INTO TRUE UTILITY VALUES REPRESENTS A MAJOR RESEARCH PROJECT. THEREFORE WE RANK EACH COLUMN OF DATA SEPARATELY, WEIGHT IT ACCORDING TO ITS IMPORTANCE, AND FORM THE WEIGHTED ROW SUM,

FIGURE 4 SHOWS HOW RANKINGS CHANGE FOR DIFFERENT SELECTIONS OF COLUMN HEADINGS, I,E,: DIFFERENT BASES OF COMPARISON, ONLY THE COUNTIES THAT RANKED IN THE TOP 25 ON AT LEAST ONE BASIS ARE SHOWN.

The "OVerall" Ranking gave equal Weight to temperature, COST, ENERGY USE IN ALL THREE CATEGORIES, NUMBER OF TOWNS AND CITIES, NUMBER OF HEATING DEGREE DAYS AND THE VALUE ADDED IN MANUFACTURING,

THE SECOND RANKING EMPHASIZES RESIDENTIAL USE WITH EQUAL WEIGHTING TO TEMPERATURE, COST, CURRENT RESIDENTIAL ENERGY USE, NUMBER OF TOWNS AND CITIES, AND THE NUMBER OF HEATING DEGREE DAYS ,

. THE THIRD RANKING STRESSES COMMERCIAL APPLICATIONS AND USES THE SAME FACTORS JUST LISTED EXCEPT THAT COMMERCIAL ENERGY USE REPLACES RESIDENTIAL.

THE FINAL COLUMN EMPHASIZES INDUSTRIAL DEVELOPMENT AND SELECTS TEMPERATURE, WELL COST, CURRENT INDUSTRIAL USE, NUMBER OF TOWNS AND CITIES, AND VALUE ADDED IN MANUFACTURING, ALL WITH EQUAL WEIGHTING. 
AS ONE CAN SEE, WE HAVE NOT MODELED ANY ASPECT OF GEOTHERMAL AREAS OR MARKETS IN DETAIL. SUCH AN APPROACH WOULD BE UNWARRANTED IN VIEW OF OUR PURPOSE AND THE DATA AVAILABLE. (THIS IS NOT TO SAY THAT MANY GEOLOGIC DATA DO NOT EXIST; ONLY THAT DATA NEEDED TO DEFINE GEOTHERMAL RESOURCES ARE INFERENTIAL IN NATURE, AT BEST.)

IN THE PRESENT FORM WE FEEL THIS APPROACH CAN HELP IN TARGETING NEW AREAS FOR EXPLORATORY EFFORTS. I STRESS THE WORD "HELP" FOR OTHERS (GEOLOGISTS; WATER, OIL AND GAS WELL DRILLERS, FOR EXAMPLE) MAY BE INVALUABLE SOURCES OF MORE LOCALIZED INFORMATION.

AS MORE RESOURCE DATA ARE GENERATED, BY WHATEVER MEANS, WELL PRODUCTIVITY INFORMATION CAN BE INCLUDED IN REASSESSMENTS. WATER TEMPERATURE INFORMATION CAN BE USED IN CONJUNCTION WITH MARKET DATA TO BETTER ESTIMATE THE FRACTION OF AN ENERGY SECTOR (RESIDENTIAL, COMMERCIAL OR INDUSTRIAL) THAT MIGHT BE ACCOMMODATED BY GEOTHERMAL ENERGY.

FINALLY, ONE CAN CONSIDER USING THE METHOD IN A STATE OR SOME PORTION OF A STATE FOR MORE LOCAL TARGETING WITHIN SUCH AREAS, 


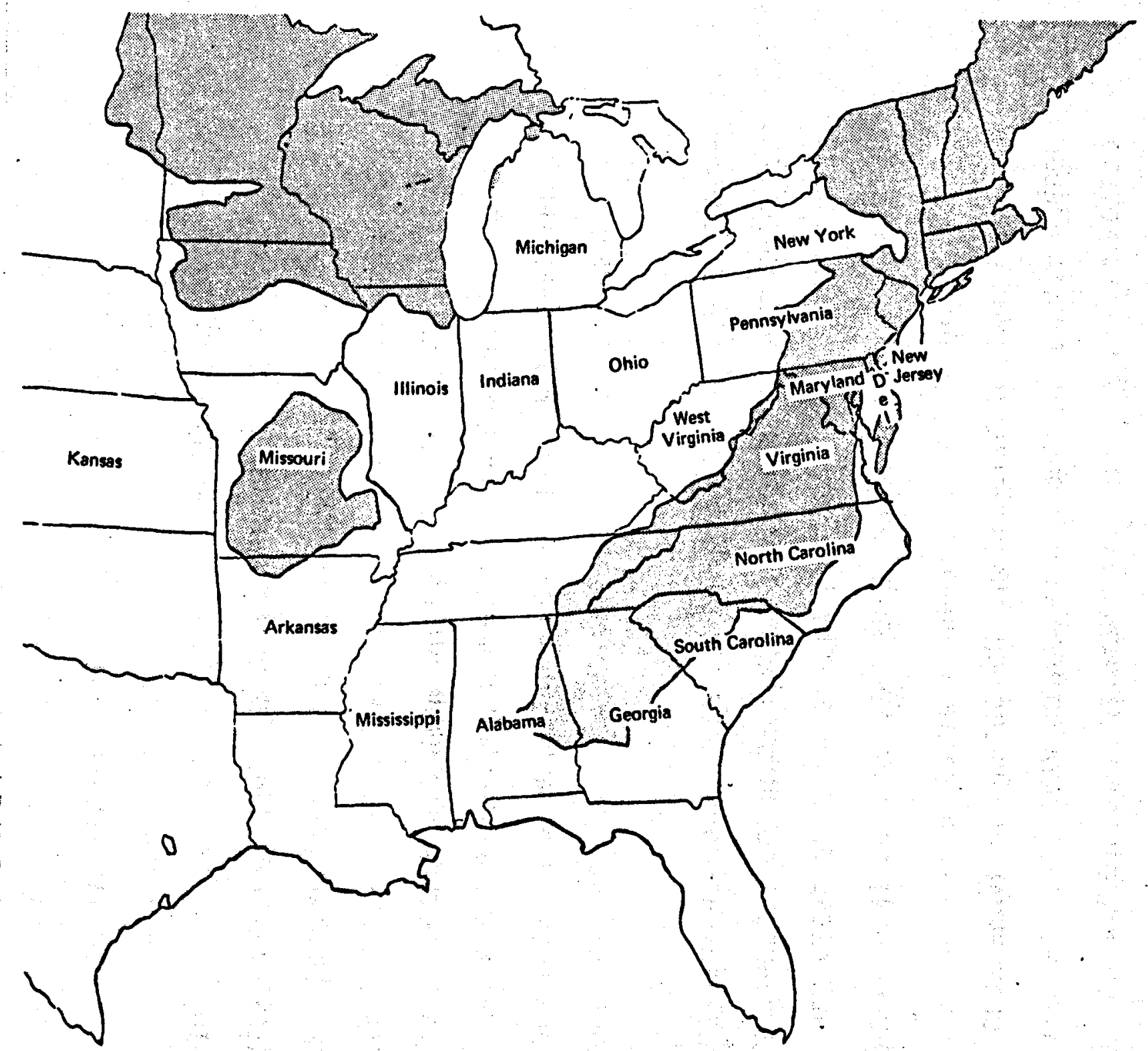

Geographical areas covered in comparative evaluation. Shaded areas are excluded without prejudice because gradient data are unavailable.

\section{FIGURE 1}


LEGEND

O. Places of 100.000 or more mnabationts

- Piaces of 50.000 10 100,000 minsbitants

Places of 25.000 to 50.000 mhabremts outsode SMSA's

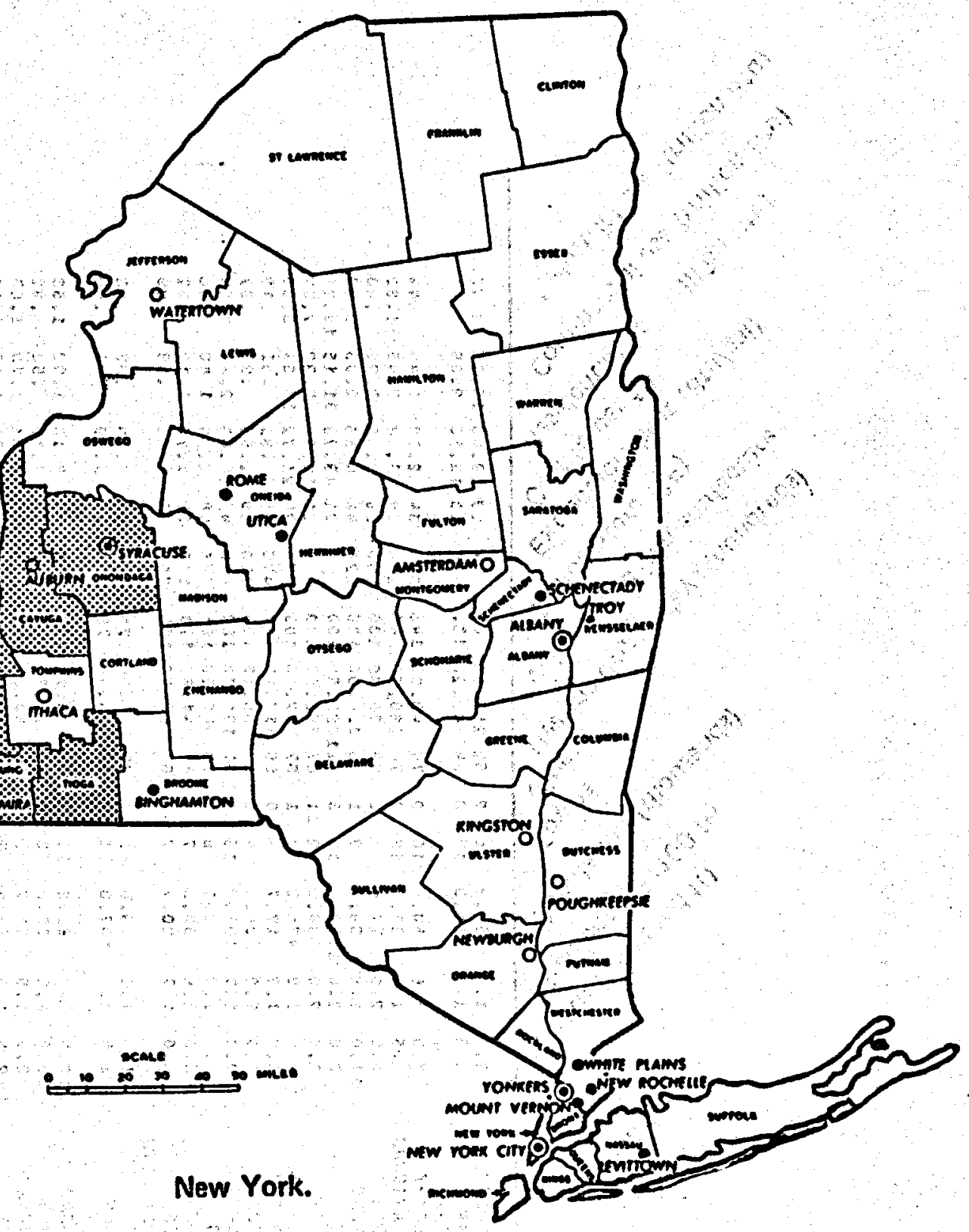

FIGURE 2 


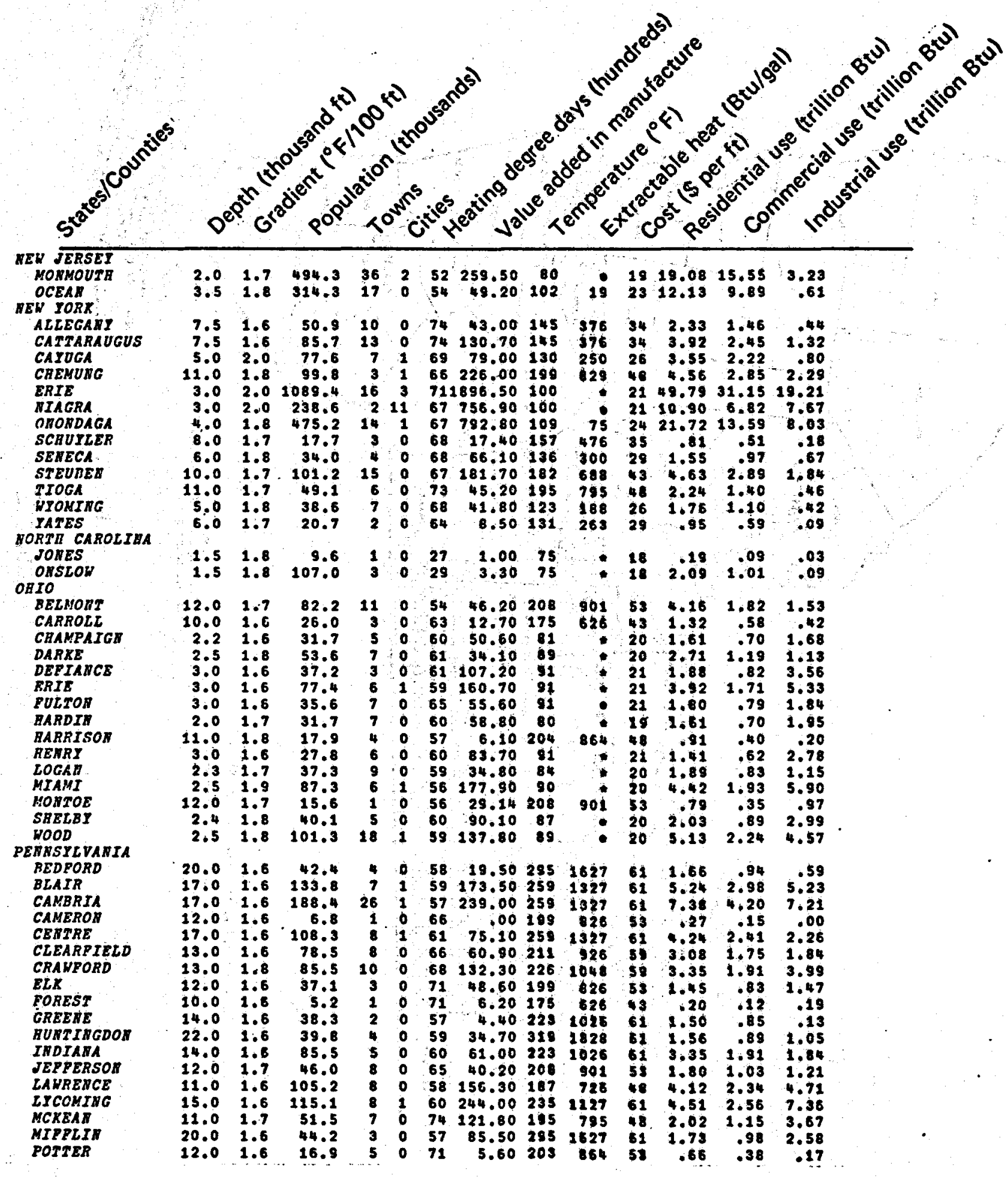

Figure 3 
Select prospects

under different criteria.

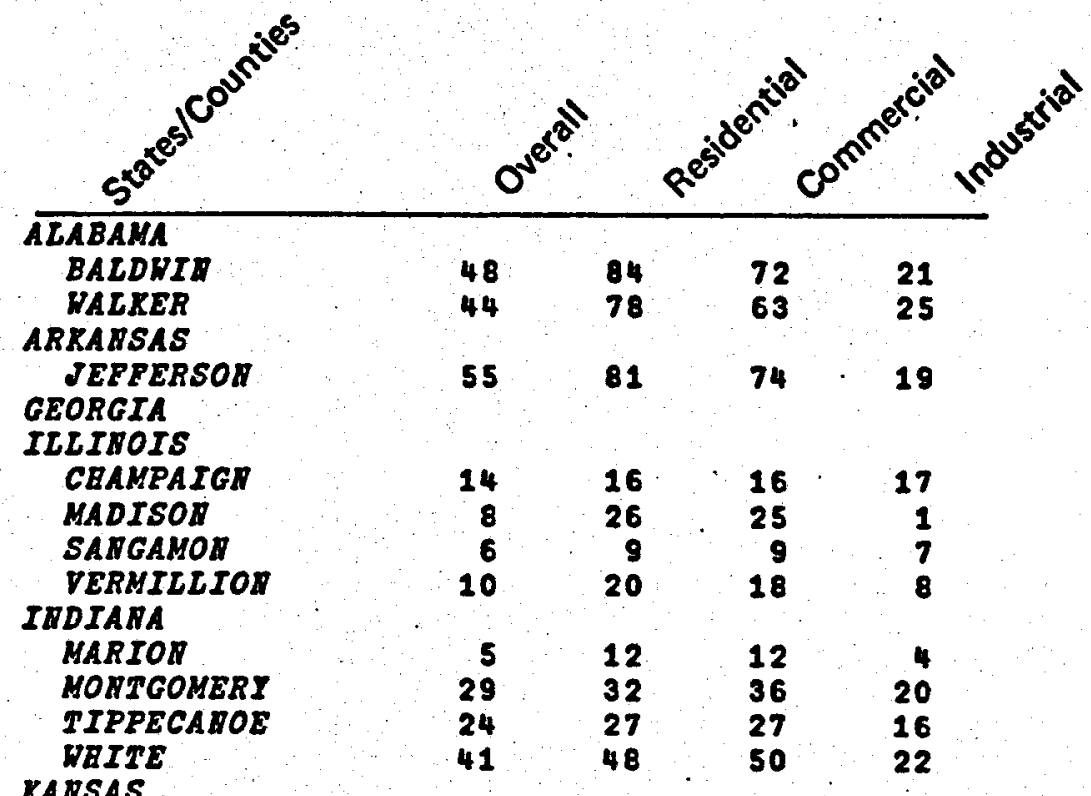

\section{MICEICAN} TUSCOLA

MISSISSIPPI

MISSOURI

IEV JERSEY

OCEAR

BEW YORK

ALLEGABY

CATTARAUGUS

CAYUGA

OROHDAGA

STEUBEN

TIOGA

WTOMING

RORTH CAROLIRA

OHIO

\section{BELMOAT}

PEWHSYLVAIIA

BLAIR

CAMBRIA

CENTRE

CLEARPIELD

CRAWFORD

JEFEERSOD

LAWRENCE

LYCOMING

MCKEAR

SOMERSET

WASHINGTOR

WESTMORELARD

SOUTE CAROLIBA

WEST VIRGINIA

MARSBALL

21

10

10

42

$\begin{array}{llll}17 & 17 & 17 & 36\end{array}$

$\begin{array}{llll}25 & 13 & 13 & 60\end{array}$

$\begin{array}{llll}12 & 4 & 4 & 29\end{array}$

$20 \quad 5 \quad 53$

$1 \quad 1 \quad 16$

$\begin{array}{llll}7 & 3 & 2 & 12\end{array}$

$\begin{array}{llll}34 & 25 & 23 & 65\end{array}$

$\begin{array}{llll}22 & 28 & 29 & 18\end{array}$

$\begin{array}{llll}13 & 14 & 15 & 11\end{array}$

$\begin{array}{rrrr}4 & 8 & 7 & 5 \\ 15 & 11 & 11 & 14\end{array}$

$18 \quad 19 \quad 19 \quad 24$

96609

$27 \quad 24 \quad 26 \quad 32$

$16 \quad 23 \quad 24 \quad 13$

$\begin{array}{lllll}11 & 15 & 14 & 10\end{array}$

$\begin{array}{llll}19 & 18 & 20 & 15\end{array}$

$\begin{array}{llll}23 & 22 & 22 & 33\end{array}$

$\begin{array}{llll}2 & 2 & 3 & 2\end{array}$

$\begin{array}{llll}42 & 58 & 60 & 23\end{array}$

FIGURE 4 


\title{
Geothermal Studies \\ West Virginia
}

\author{
by \\ H. Rieke* \\ University of W/est Virginia
}

\begin{abstract}
XXI
*Professor Rieke could not attend; this material was forwarded for inclusion in the minutes.
\end{abstract}


Recent Determinations of Geothermal Gradients and Heat Flow Values for We11-Sites In West Virginia Using an Exact Computational Method

Herman H. Rieke, III

Associate Professor, Petroleum Engineering Program, COMER, West Virginia University, Morgantown, WV 26506

A study of geothermal heat flow in a geographical region, such as West Virginia, usually requires information regarding the rock types comprising various geologic formations underlying that region and variations In the subsurface temperatures. The Fourier heat conduction equation can be employed to yleld geothermal steady state heat flows for a particular site if one can determine the 1ithology of the stratigraphic units, assign values to the thermal properties of these units and measure the temperature at the base of the lithographic column. Determination of the heat flow values for a number of sites in West Virginia would allow the mapping of subsurface isotherms. This information would be of assistance in the exploration for, the discovery and the utflization of new geothermal resources.

Information on the composition of the lithographic column and the temperature at its base is usually obtained from comercial oil and natural gas well drilling operations. Geologic and some temperature data are recorded for such wells and In West Virginia, coples of these records are forwarded to the West Virginia Geologic and Economic Survey (WVGES) 1ocated at Mont Chateau in Morgantown, WV. These data are routinely encoded for storage in a computer-based magnetic tape library maintained by the WVGES. All stored data includes well Identification, names of the various formations encountered and the depth and thickness of those formations. A judgment is made by the person(s) encoding the data regarding its quality 
and this information is included for each geologic data card. The estimate of the accuracy of the reported data is based solely upon the coder's interpretation of the source of the raw data.

Geologic data is necessary in an investigation of the geothermal heat flow owing to the calculation of the energy flux wich requires that the thermal characteristics, in the form of thermal resistivities, be obtained for the formations underlying the region under consideration. These thermal properties can be approximated if the lithology of the formations are known. The project which prompted the development of the VELLQLOG utility package was funded as a grant by ERDA-Los Alamos Scientific Laboratories (NIS-11399-1). Data requirements prompted the use of WVGES geologic data and additional field data such as bottom-hole temperatures and down-hole 1ithology. Information from the WVGES files was used as part of the data base, with extensive corrections and numerous additions made using the utility package. The form of the new file was made compatible with and similar to the records maintained by WVGES. It is explicitly recognized that the system employed by WVGES is not necessarily optimum for this type of data base.

A total of 16,291 well records from the State of West Virginia were processed, out of which 69 deep wells ( $\geq 7000 \mathrm{ft}$ deep) were found to be acceptable to this study. The lithologies for each well were determined and the heat flow values and the geothermal gradient values were calculated for each well. In this study all data is reported as "uncorrected" válues. No corrections for topography were made. A steady-state topographic model was assumed owing to the depth of these wells. A climatic base map was constructed showing variations in the mean annual surface temperatures for West Virginia and was used to provide variable 
mean annual surface temperatures in the geothermal gradient calculations.

These 69 ofl and gas wells are located in 26 West Virginia counties. The counties with the number of wells are listed.

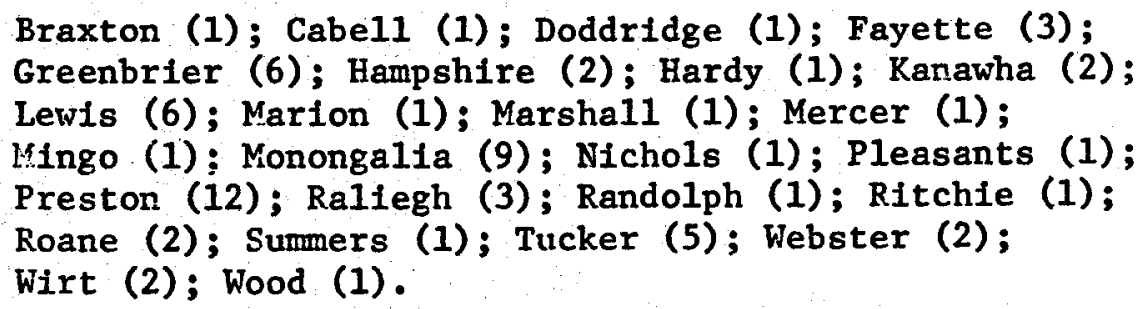

The values for the geothermal gradients ranged from $15.5^{\circ} \mathrm{C} / \mathrm{km}$

(Hampshire Co. well no. 12) to $36.6^{\circ} \mathrm{C} / \mathrm{km}$ (Webster Co. well no. 2), whereas, the heat flow values ranged from $0.70 \mathrm{HFU}$ (Monongalia Co. well no. 61) to $1.60 \mathrm{HFU}$ (Webster Co. well no. 2). These results are consistant with those previously reported values (Rleke and Skidmore, 1974). The $3 \mathrm{~km}$ isotherm values ranged from $46.5^{\circ} \mathrm{C}$ to $108.3^{\circ} \mathrm{C}$ for these wells.

Additional study is needed in order to check the computational validity of the WELL@LOG utility package with actual measured values in the fleld.

\section{References}

Rieke, H.H., III and Skidmore, D.R., 1974. Geothermal energy potential In northern Appalachia. Journ. Petrol. Tech., 26(9):1005-1006. 


\title{
Geothermal Studies
}

Saratoga Springs, N. Y.

\author{
by \\ James R. Young \\ Dunn Geoscience Corporation
}


Over the course of the last year, Dunn Geoscience Corporation has conducted a comprehensive research program into the origin of the naturaliy carbonated waters of the City of Saratoga Springs. This study has utilized two preliminary techniques of geothermal investigation: geologic 11terature review and, principally, geochemistry. The results have been positive on most counts and have demonstrated a high probability of a thermal derivation for portions of the Saratoga waters with indications that a concealed convective geothermal system may exist at depth under the shales of the upper Hudson RIver Valley. Briefly summarized these are:

(1) Analogy; all known global occurrences of carbonated waters whtch are similar to Saratoga ( $1 . e .$, with free $\mathrm{CO}_{2}$ gas and low $\mathrm{pH}$ ) are elther directly related to obvious thermal sources (volcaniclty, anomalous heat flow, metamorphism at depth) or show some other evidence of thermal derivation.

(2) The lack of significant sulfates, nitrates and nitrites in most of the carbonated waters, a fact which is incompatible with known low temperature methods of $\mathrm{CO}_{2}$ formation.

(3) A net flux of $\mathrm{CO}_{2}$ through the system, indicating the addition of the gas is a dynamic, not a fossil process.

(4) A distinct negative $\sigma^{18} \mathrm{O}$ "shift" In the water indicating the $\mathrm{CO}_{2}$ gas originated at elevated temperatures.

(5) Anomalous quantities of dissolved $\mathrm{SHO}_{2}$ up to $70 \mathrm{mg} / 1$ (after dilution with cold, shallow waters) Indicating that a fluld zone of heat exchange is associated with the Saratoga system.

The carbonated waters have been found over an area of nearly 1,000 square miles from Albany north to Lake George and from Amsterdam eastward to the state of Massachusetts. Often they are found mixed with the remnant components of a connate basinal water rising from the deep Paleozolc carbonate aquifer burled beneath the shales. Just as of ten the $\mathrm{CO}_{2}$ is present in meteoric ground water 
In shallow water wells implying a separation of the gas phase from the deeper basinal waters. In all cases, the measured temperatures of the carbonated waters at the surface have been found to be between $9^{\circ}$ to $12^{\circ} \mathrm{C}$, ambient for this area.

Evidence at this time is indirect (1.e., $\mathrm{SiO}_{2}$ and isotopic data), yet very strong that the original carbonated fluld was produced at temperatures above $300^{\circ} \mathrm{C}$. The matter of recoverable heat at drillable depths is unknown at this point; though the silica anomaly offers some positive indications that usable energy may be recovered. The search for more direct evidence of subsurface heat is the subject of an ongoing program involving further geochemistry, deep-hole gradient measurements, systematic silica determinations, and a seismic monitoring network. 
$\sigma$

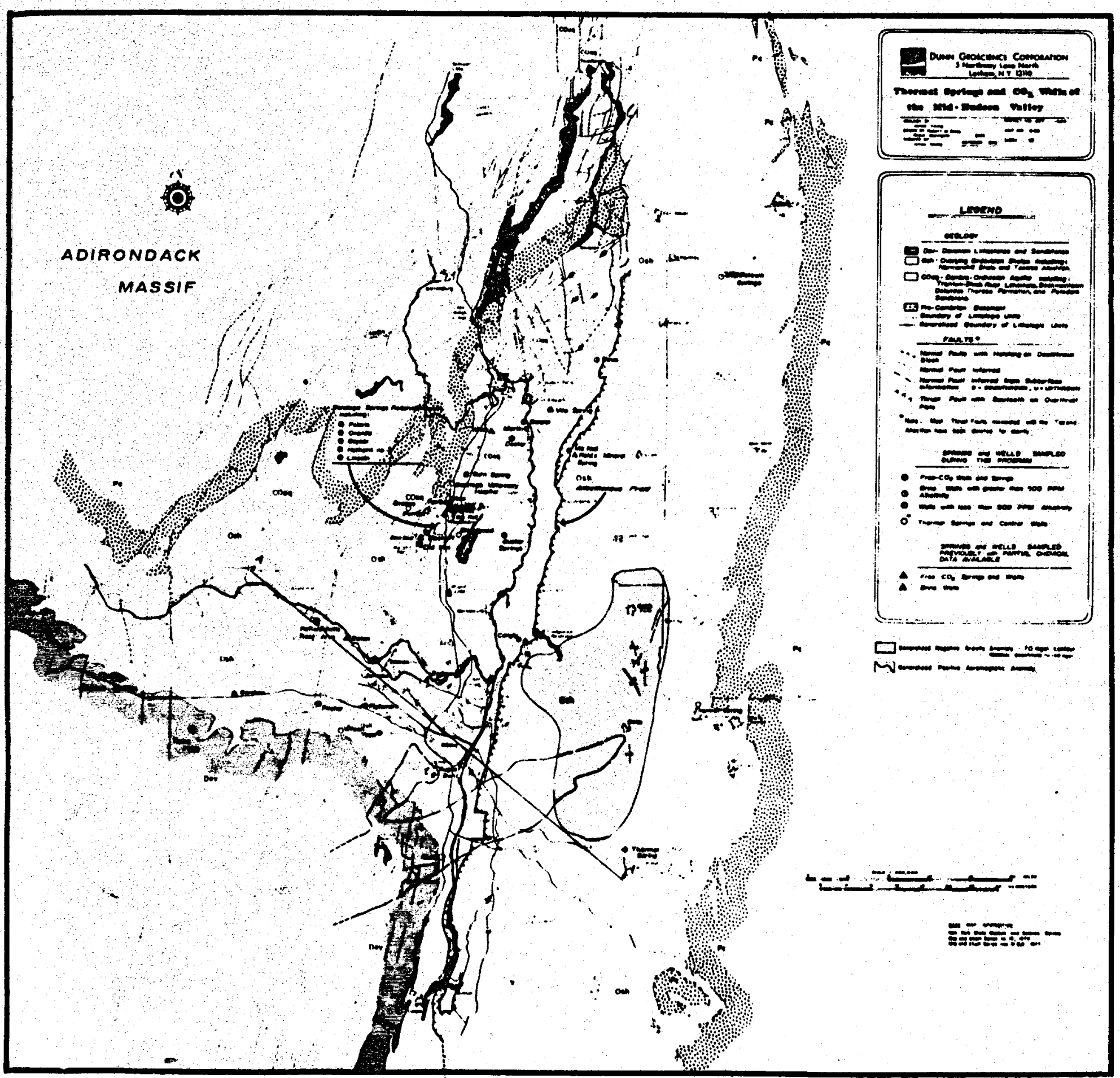




\title{
Geother mal Studies \\ Western New York
}

\author{
by \\ Kenneth G. Hilfiker \\ State University of New York \\ (Buffalo)
}

XXIII 


\section{PREL IMINARY GEOTHERMAL INVESTIGATIONS IN NEW YORK STATE}

Dennis S, Hodge, * Kenneth Hilftker,*

Paul Morgan, $*$ and Chandler A. Swanberg**

*SUNY/Buffalo, Amherst, NY 14226

* New Mexico State University, Las Cruces, NM 88003

\section{ABSTRACT}

The AAPG temperature gradient map and the few avallable published heat flow data for the area Indicate a possible potential for geotherma 1 resource in western and central New York State. A new analysis of bottom hole temperature data for the state confirms the existence of two positive oradient anomalies the East Aurora and Cayuga anomalies, with gradients as high as $27^{\circ} \mathrm{C} /$ $\mathrm{km}(1.5 \cdot \mathrm{F} / 100 \mathrm{ft}$.$) and 30 \cdot \mathrm{C} / \mathrm{km}(1.6 \circ \mathrm{F} / 100 \mathrm{ft}$. respectively. Groundwaters from both anomalies are enriched in silica concentration relative to surrounding areas. Heat flows based on silica geothermonetry are 50-70 $\mathrm{mhm}^{-2}$. for the anomalles and $41.4 \mathrm{mWm}^{-2}$ for regional heat flow. A correlation between Bouguer gravity anomalles and the temperature gradient map suggests that the source of the geothermal anomalies may be radiogenic granites in the Precambrian basement rocks.

\section{INTROOUCTION}

Inspection of the AAPG temperature gradient map for the U.S. reveals that two of the most prominent anomalies in the eastern U.S. are located near Cayuga Lake and East Aurora, New York. Temperature gradient values in excess of $36^{\circ} \mathrm{C} / \mathrm{km}\left(2.0^{\circ} \mathrm{F} / 100 \mathrm{ft}.\right)$ were estimated from corrected bottom hole temperatures from ofl and gas boreholes. Since these two areas are located near large population centers, considerable potential exists for the use of geothermal energy and an evaluation of the subsurface temperatures, heat flow, and the source of the anomalles has been undertaken.

The initial study focused on a (1) preliminary geochemical sampling of the two areas for geothermal evaluation, (2) analysis of gravity data to determine the subsurface mass distribution and (3) acquisition of a complete data set of bottom hole temperatures within New York State.

The only published heat flow data for central and western New York is the work of Diment et al. (1972). Four heat flow values of $50 \mathrm{mHm}^{-\frac{2}{2}}(1.2 \mathrm{HFU})$ are given for areas near Buffalo. New York, and from boreholes southeast of Syracuse values of 59 and $71 \mathrm{mkm}^{-2}(1.4$ and 1.7 HFU) were obtained. These heat flow values are significantly above the norm for the eastern U.S. a though Diment et al. question the reliability of some of the data. The values indicate, however, that anomalously high heat flow may

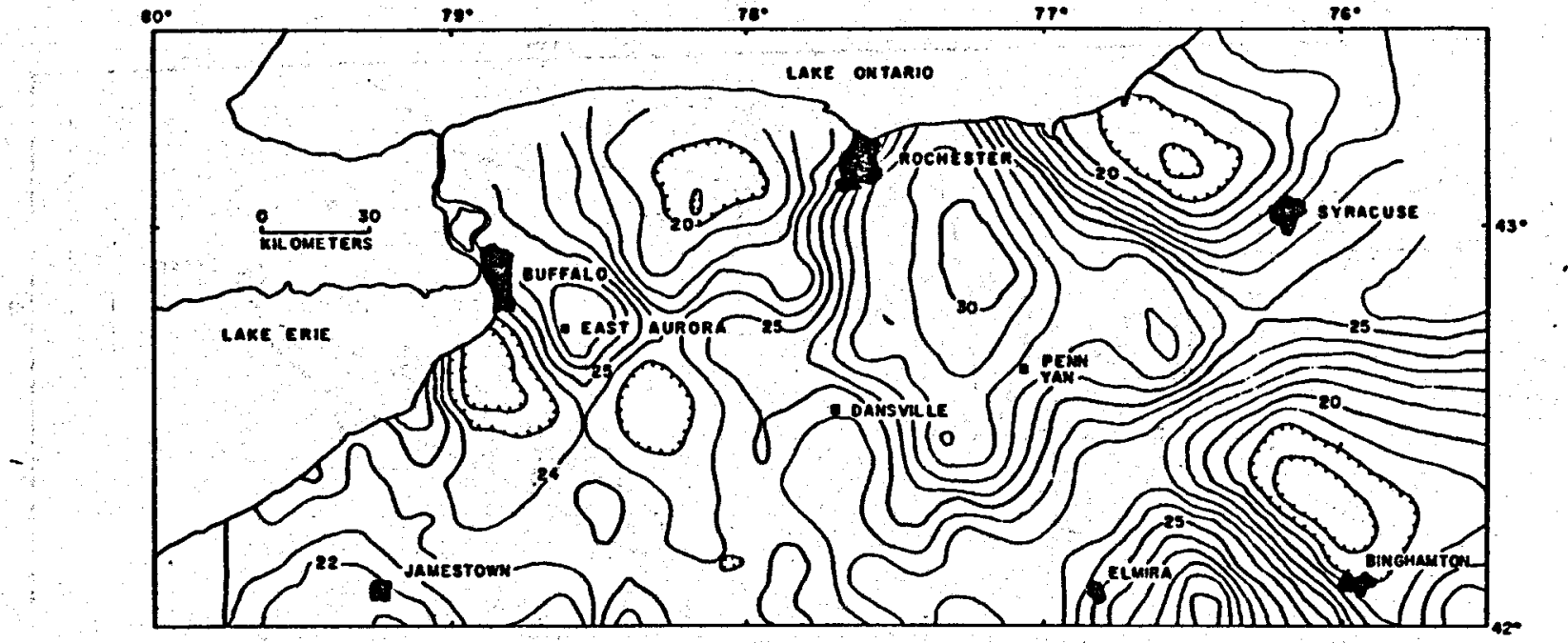

Fig. I Temperature gradient contours in ${ }^{\circ} \mathrm{C} / \mathrm{km}$ computed from borehole bottom hole temperature data. 


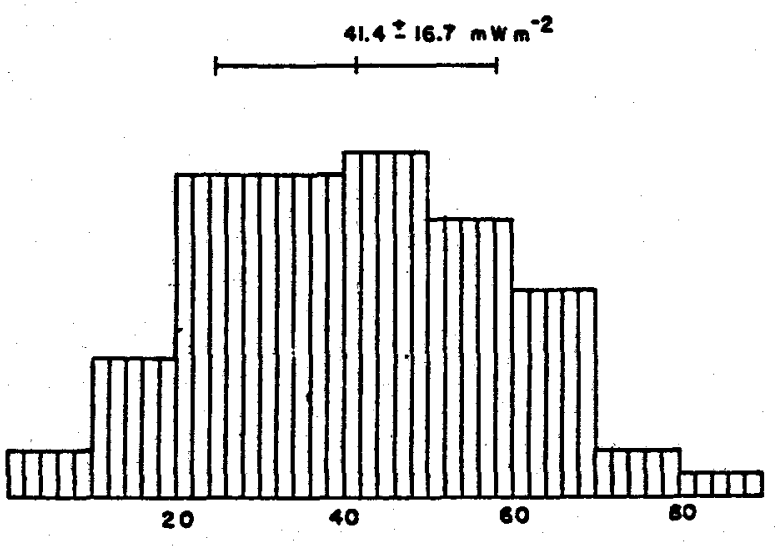

Fig. 2 Frequency histogram of silica-heat flow values.

exist within the region in restricted areas.

\section{REGIONAL GEOLOGY}

With in the central and western portion of New York State the geologic structure is relatively simple. Cambrian through Devonian shales and limestones dip gently to the south and the thickness of this sedimentary sequence is about $3,000^{\circ}$ at the shore of Lake Ontario and thickens to the south to over $10,000^{\prime}$ in scme areas. Precambrian crystall ine basement rocks underl ie these Paleozoic sediments. The Paleozoic rock section also contains some evaporites but is composed principally of shales and sandstones.
A thin veneer of glacial debris covers most of the area and may reach thickness as great as 600 feet in some valleys.

\section{TEMPERATURE GRADIENTS}

The temperature gradient map prepared by the AAPG (1976) for the geothermal survey of North America made use of bottom hole temperature data from approximately 125 well's in New York state. Bottom hole temperatures from many more wells are now avallable, and the gradients from the central and western portions of the state have been reevaluated using a data set from 837 wells.

Surface temperatures for the gradient calculations were estimated from mean annual temperatures at 56 recording stations throughout the state compiled by NOAA. The temperatures were corrected to sea level using a lapse rate of $3 \circ \mathrm{C} / \mathrm{km}$ and a second order trend surface was fitted through the data. The trend surface was then used to calculate a surface temperature at each borehole location. Unlike the AAPG data analysis, no corrections for drilling disturbances have been applied to the bottom hole temperatures. The majority of the wells in New York are gas wells, drilled using air not mud, and the results from wells where multiple bottom hole temperatures have been measured indicate that no drilling disturbance correction is applicable. Gradients were calculated from the bottom hole temperature recorded during routine logging runs minus the estimated surface temperature, divided by the well depth.

Calculated gradients ranged from $10^{\circ} \mathrm{c} / \mathrm{km}$ $(0.5 \cdot \mathrm{F} / 100 \mathrm{ft}$.) to $42 \cdot \mathrm{C} / \mathrm{km}(23 \cdot \mathrm{F} / 100 \mathrm{ft}$. $)$ and, where the data came from wells greater than 500 m in depth, the gradients are locally consistent, i.e. gradients calculated from nearby wells are sfimilar in magnitude. The data from wells less than 500 in deep generally give locally variable 10

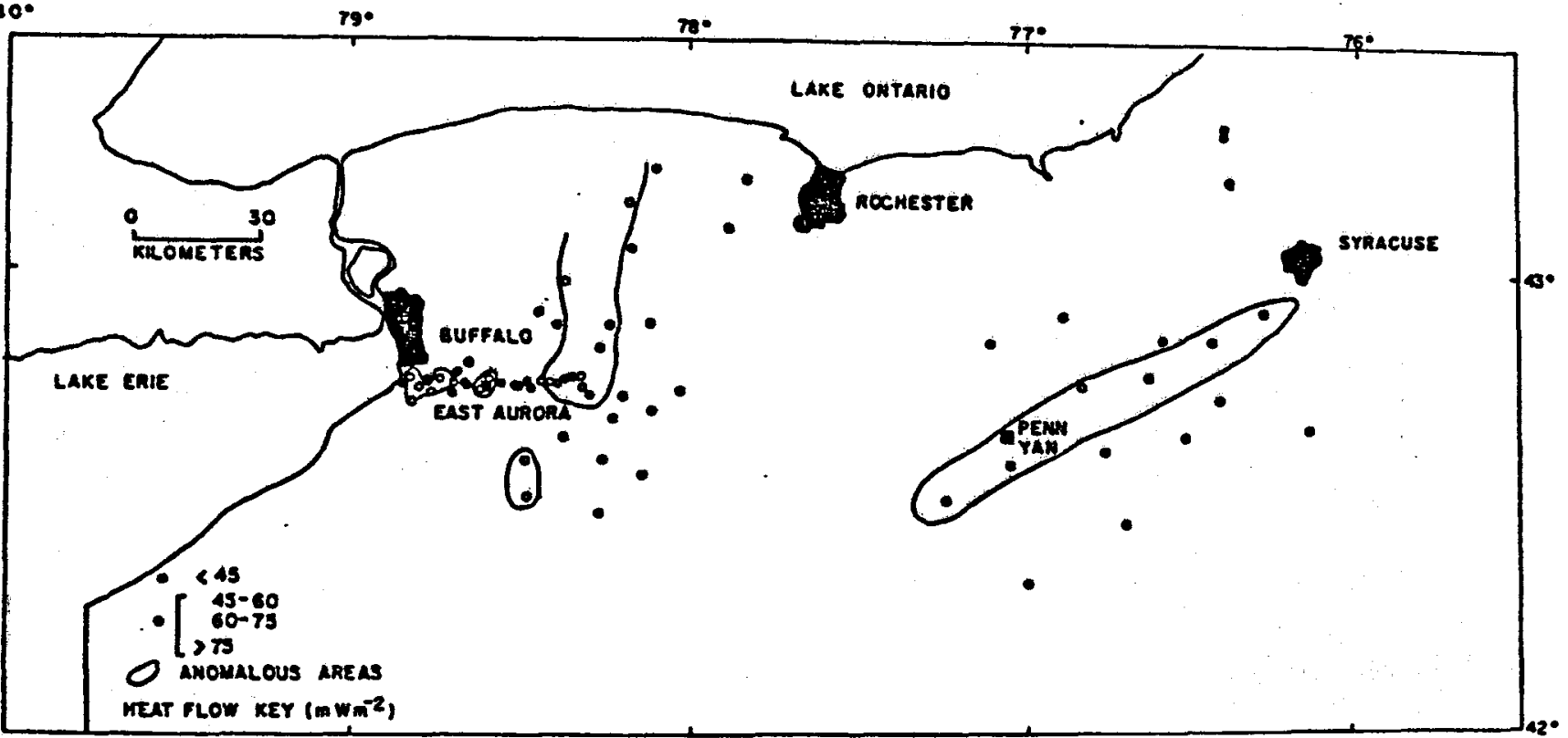

Fig. 3 Map of high silica-heat flow values. 
Hodge et ar.

gradients which probably reflect the temperatures of relatively shallow groundwater circulation systems rather than the temperatures of the underlying strata. Many of these wells were in the area Immediately northeast of Buffalo. Data from all wells shallower than $500 \mathrm{~m}$ were rejected, and the contour map shown in Figure 1 was prepared using an automated contouring routine from the data for the remaining 739 wells in the data set.

The revised temperature gradient map has the same bastc features as the AAPG gradient map, but with much greater detall and a modifled posttfoning and shape of the main anomaltes. To the southeast of Buffalo, a positive anomaly near East Aurora is again delineated with gradients in excess of $27 \cdot \mathrm{C} / \mathrm{km}(1.5 \cdot \mathrm{F} / 100 \mathrm{ft}$.$) . New data from$ the central portion of the state indicate that the positive anomaly centered near Cayuga Lake on the AAPG map has its peak further to the west, between Rochester and the town of Penn Yan, and has gradients in excess of $30 \cdot \mathrm{C} / \mathrm{km}(1.6 \cdot \mathrm{F} / 100 \mathrm{ft}$. The reanalys is of the bottom hole temperature data from western and central New York therefore confirms the validity of the high gradient anomalies shown on the AAPG map and repositions the Cayuga anomaly.

\section{GEOCHEMISTRY}

Seventy-five samples of groundwater from the Cayuga and East Aurora anomalles and their adjacent areas were collected and chemically. analyzed in order to determine whether or not evidence of hydrothermal activity could be detected from their chemical constituents. Standard techniques of qualitative and quant itative geothermometry fincluding the sllica, NaKCa, and NaKCaMg geothermometers were applifed to the data and the results were compared to the other geophysical results. None of the samples showed clear evidence of having originated with in an active hydrothermal system. More encouraging results, however, were obtained by using the silica-heat flow method of Swanberg and Morgan (1977/78).

Figure 2 is a frequency histogram of heat flow values obtained by applying the sillcaheat flow method. The mean regional heat flow predicted for the study area is $41.4 \mathrm{mhm}^{-2}$ (1.0 HFU), a value which is tectonically reasonable and consistent with the values obtained by the traditional heat flow techniques (Diment et al.. 1972). Further, an attempt was made to Fsolate the higher silica-heat flow values to determine whether or not their areal distribution would delineate the Cayuga and East Aurora anomalfes in a similar manner to the gravity and bottom hole temperature data. Figure 3 shows the areal distribution of the higher silica-heat flow values ( $45 \mathrm{mbm}^{-2}$ ) along with the rest of the data set. This approach appears to work reasonably well for the Cayuga anomaly. The higher values plot along a line trending northeastsouthwest through an area which includes the Cayuga anomaly as defined by the bottom hole temperature data (Figure 1), the gravity data (Figure 4), and the previously pubilshed temperature gradient map of North America (AAPG, 1976).

The sllica technique is only partially successfui for the East Aurora anomaly. As shown in Figure 3, the higher silica-heat flow values tend to cluster in several discrete groups throughout an area which includes the East Aurora anomaly but not in the same pattern as evidenced by the gravity and bottom hole temperature data (FIgures 1,4 ). Part of this problem probably results from the nature of the groundwaters avallable for study. At the Cayuga anomaly, the samples were collected from wells that penetrated well into the sedimentary section and therefore represent "old" meteoric waters that have circulated within the sedimentary section for a sufficientiy long perlod of time to achieve chenical equilibrium with the host

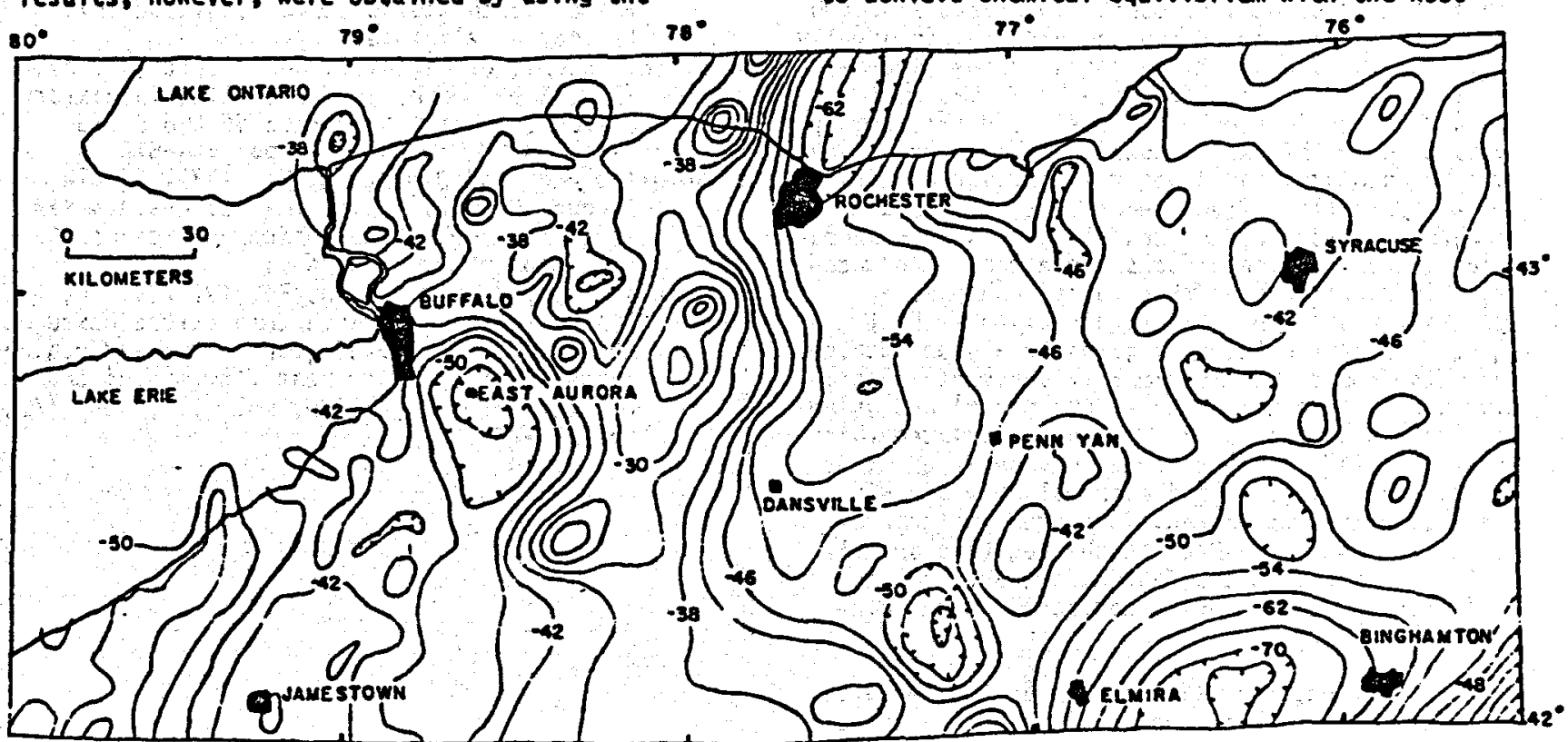

Fig. 4 Bouguer gravity map of central and western New York State. (after Revetta and Oiment, 1971). 
Hodge et al.

rock. Such equilibrium is a fundamental requirement of chemical geothermometry. On the other. hand, the waters from the East Aurora area were sampled from wells in topographic lows penetrating glactal tills. Such waters may reflect "new" meteoric waters which have not had sufficient time in the ground to achieve chemical equilibrium. On the basis of the silfica data both geothermal areas have heat flows in the 50-70 $\mathrm{mm}^{-2}$ range.

\section{BOUGUER GRAYITY OF CENTRAL AND WESTERN NEW YORK}

The Bouguer gravity map of central and western New York (figure 4) has been in most part taken from the Bouguer map of New York State (Revetta and Diment, 1971). The pattern of the Bouguer anomalies can be separated into two distinct zones separated by a north trending high gradient area that lies to the west of Rochester and extends as far south as Arcade, New York. This high gradient zone coincides with the Clarendon-Linden fault zone. The Bouguer anomaly field in the western map area shows distinct positive and negative closed anomalfes with a prominent negative anomaly located near East Aurora, New York (the East Aurora Anomaly).

In the eastern part of the map area the anomalies are much more subdued with few positive anomalies. A low amplitude negative anomaly is located about $20 \mathrm{~km}$ east of Rochester and extends In a north-south direction to the area around Penn Yan, New York. This negative anomaly (the Cayuga Anomaly) coincides with a distinct temperature gradient anomaly shown in Flgure 1 . The Bouguer anomalies on the southeast corner of Figure 4 decreased to $-76 \mathrm{mgals}$ and this area coincides with bedrock depths in excess of 12,000 feet.

Because undeformed near-horizontal sedimentary rocks are found to depths in excess of 3,500 feet, the character of the Bouguer field generally reflects the density differences in the Precambrian basement. Similar Precambrian basement rocks outcrop in southern Ontario and the Bouguer gravity over this area shows a strong correlation with P.c geology; the Bouguer field over granitic rocks typically reflect negative anomalles and gabbroic igneous rocks show strong positive anomajies. These plutonic rocks are enclosed in metamorphic rocks. Using this relationship as a general gutde, the negative anomaly over East Aurora is attributed to a granitic pluton located near the top of the Precambrian basement. Assuming a density contrast of $-0.09 \mathrm{gm} \mathrm{Cc}^{-1}$ and using a simple slab approximation, the calculated thickness of this density contrast may be as great as $5 \mathrm{~km}$. The Cayuga negative anomaly may likewise be interpreted as a granitic pluton in the Precambrian basement. Because the negative anomaly is not as large as the East Aurora anomaly, the thickness of this density contrast may be somewhat less.

A distinct correlation between the temperature gradient map and the gravity map is apparent (ffgures 1 and 4). The East Aurora negative gravity anomaly coincldes spacially with a positive temperature gradient anomaly. The Cayuga temperature gradient anomaly trends in a north-south direction with the highest gradients delineated by the $30^{\circ} \mathrm{C} / \mathrm{km}(1.6 \circ \mathrm{F} / 100 \mathrm{ft}$.) with a smaller anomaly following a east-west trend. This north-south trend correlated again with a negative Bouguer gravity anomaly. The correlation between the Bouguer gravity map and the temperature gradient map suggests that the source of the thermal anomalies may be due to radiogenic heat from granitic rocks in the Precambrian. Low geothermal gradients are found with low gravity values in the southeastern portion of the map. This is the area with the thickest sedimentary sequence, however, and the low gravity reflects the thick sediments rather than basement granites.

\section{CONCLUSIONS}

These studies have confirmed the existence of significant geothermal anomalies in central and western New York State. Further studies are required to define the magnitude and extent of. the geothermal anomalies.

\section{ACKNOWLEDEMENTS}

R. DeRito assisted with the temperature gradient data reduction. Analyses of water samples were performed by $D$. Borden. We are grateful for background geologic and geophysical information supplied by $Y$. Isachsen. Major funding for this study was provided by grant numbers NP89182FI and N284936HI from the LOS Alanos Scientific Laboratories.

\section{REFERENCES CITED}

A.A.P.G.-U.S.6.S. (1976), Subsurface temperature map of North Anerica, U.S. Geol. Survey, Arlington, Virginia.

Diment, H. H., Urban, T. C. and Revetta, F. A., 1972. Some geophysical anomalies in eastern United States: The Nature of the Solid Earth, N.Y. MCGraw HIII, Pp. 544-572.

Revetta, F.A. and Diment, W. H., 1971, Simple Bouguer Gravity Anomaly Map of Western New York: New York State Museum and Science Service Geol. Sur. Map No. 17.

Swanberg, C. A., and Morgan, P., 1979/79, The linear relation between temperature based on the sllica content of groundwater and regtonal heat flow: A new heat flow map of the United States: PAGEOPH, vol. 117, nos. 1/2, pp. 227-241. 


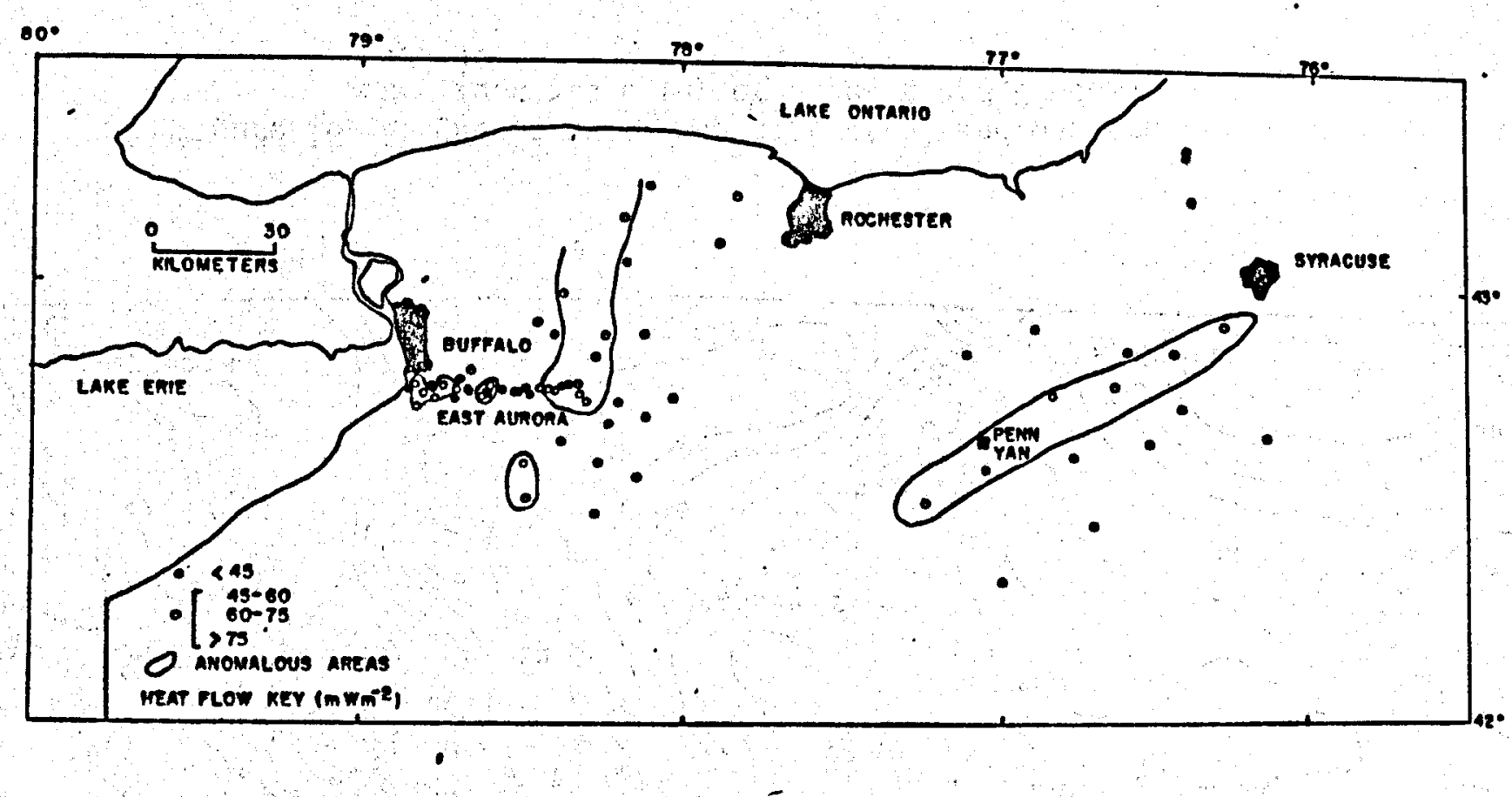

Figure 15 Map of high silica-heat flow values. 


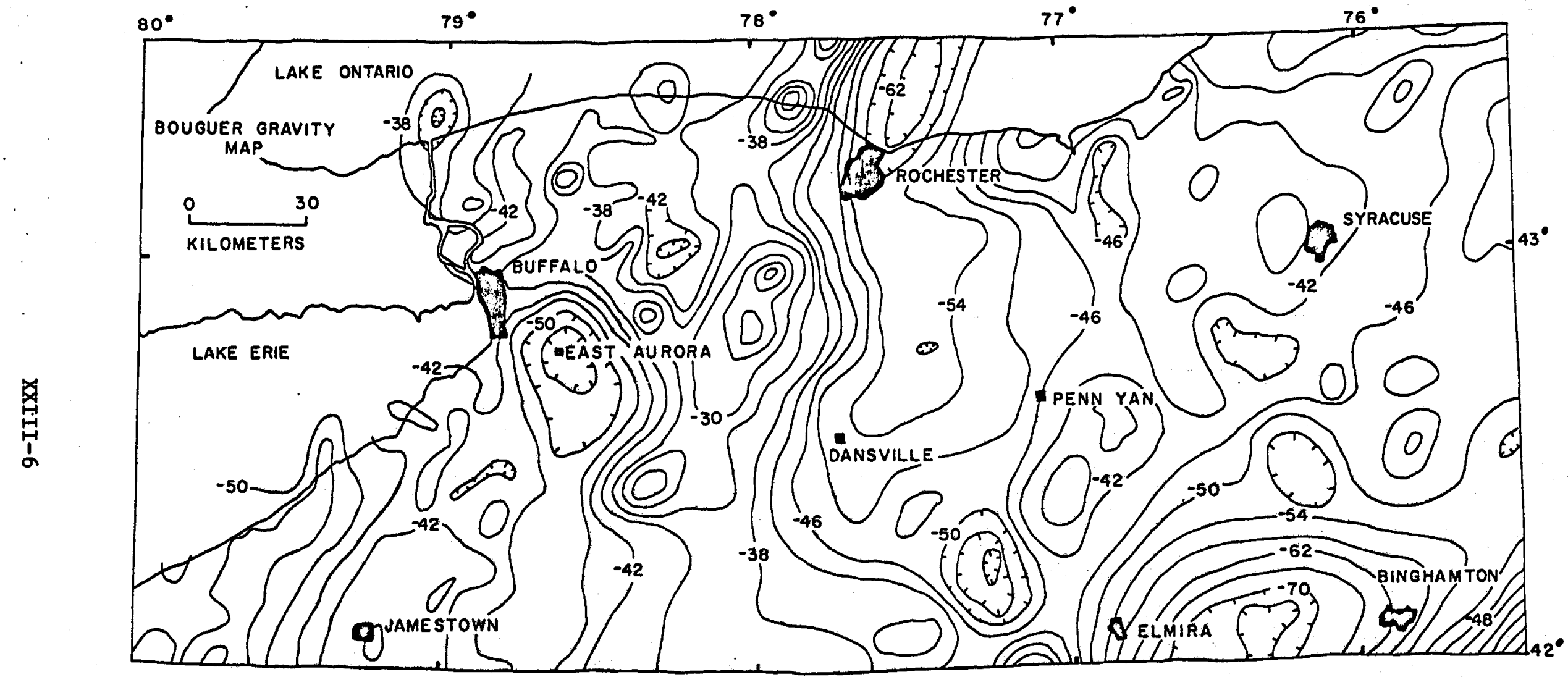

Figure 16 Bouguer gravity map of central and western New York State (after Revetta and Diment, 1971). 


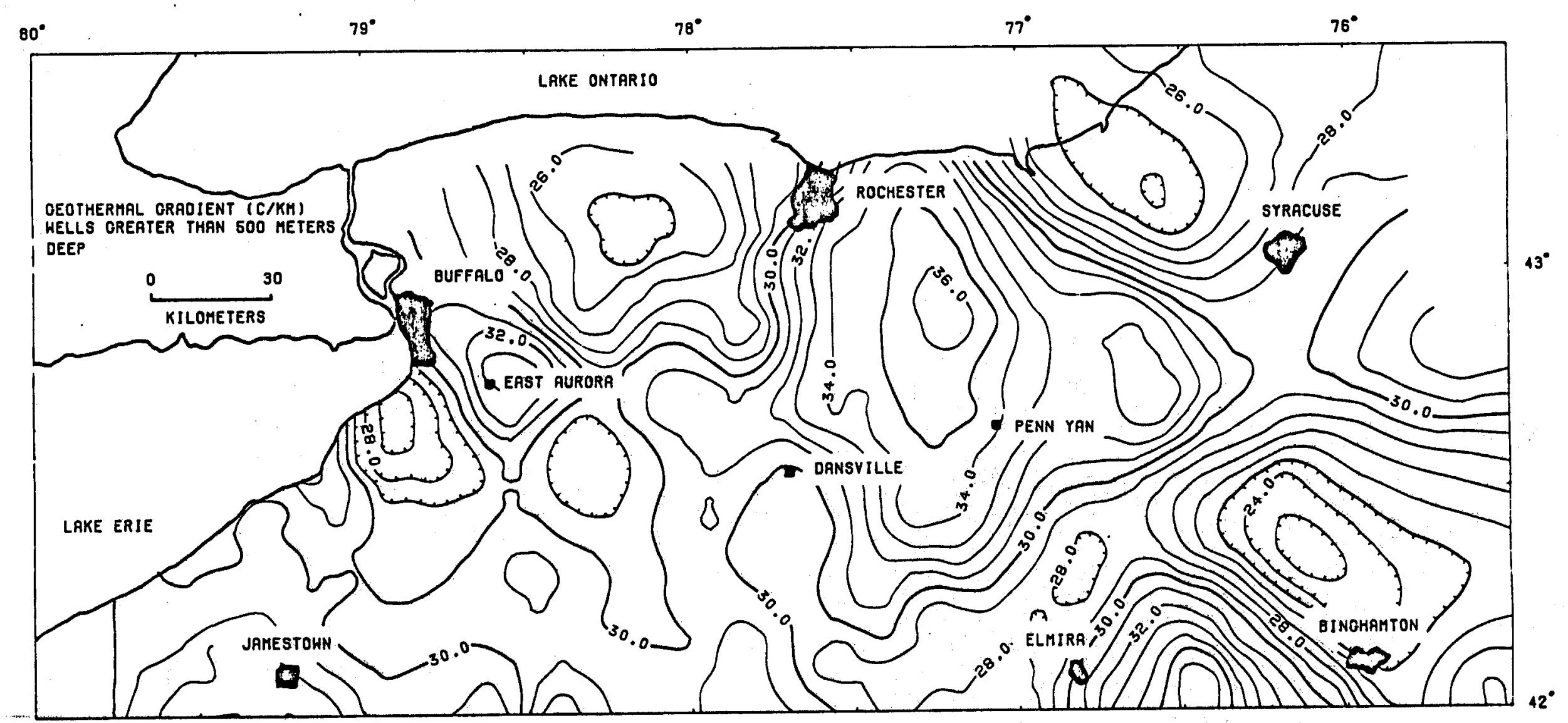

Figure 7 Contoured temperature gradients for all wells 1

greater than 500 meters assuming drilling disturbance correction as in Figure 6 . 


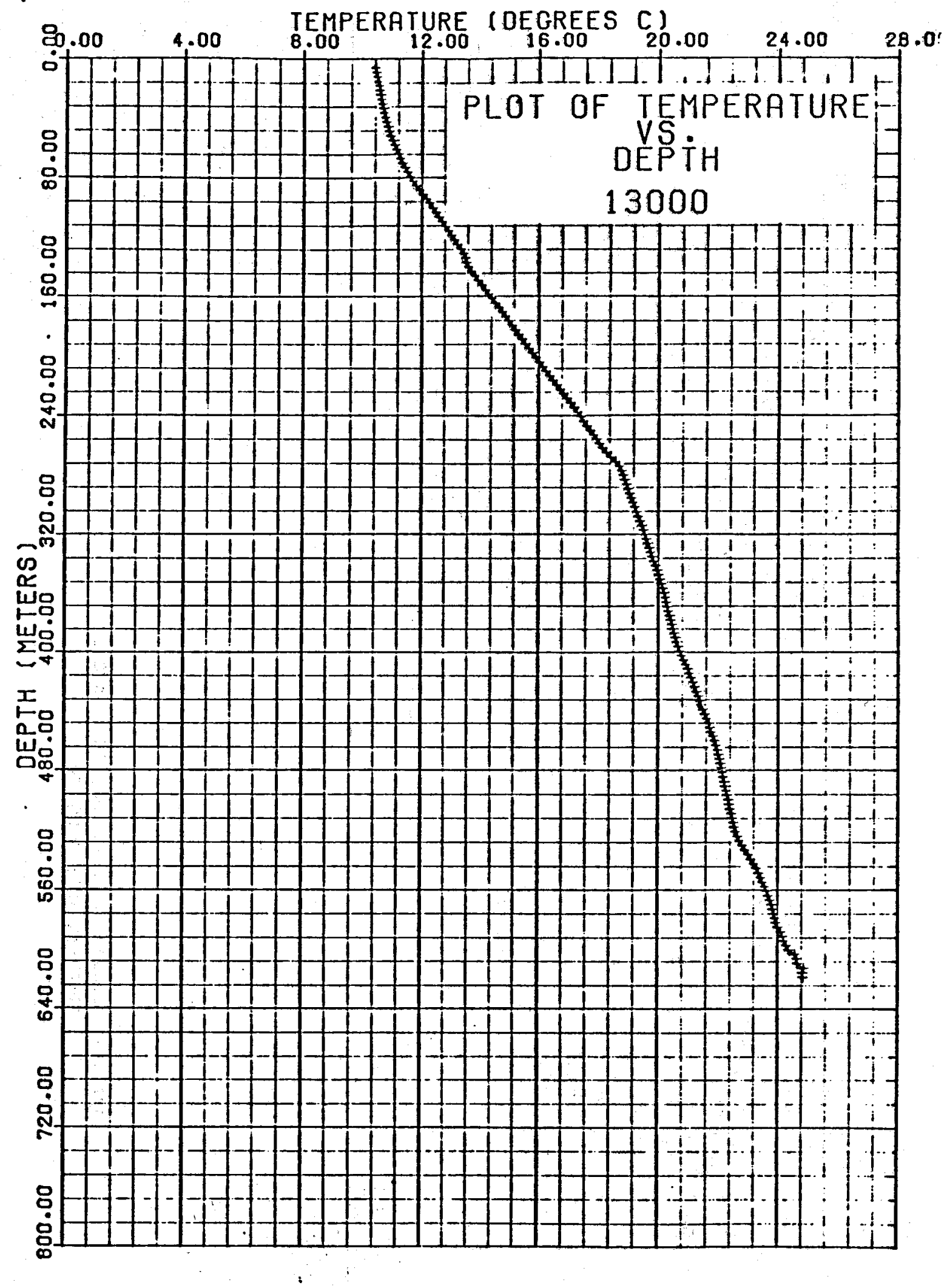

Figure 10 Temperature log of well \#13,000 showing yery distinct breaks in geothermal gradients. 


\section{Geothermal Studies}

Nebraska

by

W. D. Gosnold, Jr.

University of Nebraska

(Omaha) 


\section{INTRODUCTION}

The goal of the State Coupled Resource Assessment Program in Nebraska is to identify and evaluate low-temperature geothermal resources in the state. To achieve this goal we have undertaken the following three tasks: compile existing data on the geothermal regime of Nebraska, drill about 30 shallow $(150 \mathrm{~m})$ heat flow holes, and prepare appropriate maps to display the results of the first two tasks.

\section{Existing Data.}

One phase of the first task is the compilation of bottom-hole temperatures and other data from about 13,000 existing oil and gas wells in the state. This project is underway at the Conservation and Survey Division of the Nebraska Geological Survey where the data are filed on drilling reports. The data will be stored on magnetic tape and then processed to produce a geothermal gradient map of Nebraska. A correction for the mean annual surface temperature will be applied to the data. The map will be a considerable refinement of the information shown on the A.A.P.G. Geothermal Gradient Map of North America (A.A.P.G.,1976) which is based on only a few hundred data points within the state.

Another phase of the first task is the assimilation of data from other studies related to the geothermal regime of Nebraska. Data have been assembled from conventional heat flow studies, a silica geothermometry study, the A.A.P.G. map, and studies by the Nebraska and South Dakota Geological surveys.

Prior to 1978 no heat flow determinations had been made for Nebraska, but several studies gave data for the surrounding regions (Roy et. al., 1968; Roy et. al., 1971; Sass et. al,, 1971; and Combs and Simmons, 1973). Figure 1 shows the heat flow values for the reglons surrounding Nebraska given by Combs 
and Simmons (1973). Combs and Simmons (1973) distinguish the Interior Lowlands Province with a heat flow of 1.4 H.F.U. $\left(56 \mathrm{mw} / \mathrm{m}^{2}\right)$ from the Northern Great Plains Province with a heat flow of $2.0 \mathrm{H.F}$. U. $\left(84 \mathrm{mw} / \mathrm{m}^{2}\right)$ and include Nebraska in the Southern Great Plains Province which has a regional heat flow about the same as that of the Interior Lowlands. Lachenbruch and Sass (1977) and Sass et. al. (1979) suggest that western Nebraska has a heat flow ranging from 1.5 H.F.U. to $2.5 \mathrm{H.F.U.}\left(63\right.$ to $\left.106 \mathrm{mw} / \mathrm{m}^{2}\right)$. Figure 2 is a reproduction of the heat flow map given by Lachenbruch and Sass (1977) and shows that the 1.5 H.F.U. contour line approximately parallels the boundary between the Great Plains and the Interior Lowlands and is additionally determined by one heat flow value in Kansas and one in South Dakota. Gosnold (1979) made ten heat flow determinations in Nebraska and generally confirmed the suggestions of Lachenbruch and Sass (1977). Gosnold (1979) Identified a small heat flow anomaly in southeastern Nebraska that is caused by a combination of high heat generation in the basement rocks and by refraction of heat in the uplifted Nemaha Ridge (Figure 3).

Swanberg and Morgan (in press) show a significant heat flow anomaly that covers much of western Nebraska and includes parts of South Dakota, Wyoming, Colorado, and Kansas. The anomaly is inferred on the basis of geochemical analyses of well and spring waters and the application of the silica geothermometer (Fournier, 1973) and is outlined in Figure 4. Although recent heat. flow determinations (Gosnold, 1979) confirm the existance of high heat flow in western Nebraska, too few data are available to confirm the inferred anomaly as a distinct heat flow province. 
The Nebraska section of the A.A.P.G. map (A.A.P.G., 1976) indicates several regions with high geothermal gradients within the state (Figure 5). In general the northern, western, and eastern parts of the state have the highest gradients, with vaules greater than $36^{\circ} \mathrm{c} / \mathrm{km}$, and the southern and central parts of the state have the lowest gradients.

The geothermal gradient map of South Dakota (Schoon and McGregor, 1974) shows an elongate zone of gradients greater than $91^{\circ} \mathrm{C} / \mathrm{km}$ that is flanked by zones of gradients greater than $54^{\circ} \mathrm{C} / \mathrm{km}$ in the southern part of the state. Figure 6 shows the high gradient zones have a linear trend which may extend into northeastern Nebraska. At present no data are available for this section of Nebraska.

Heat Flow Holes.

The majority of the drilling is planned for the 1980 field season so that the results from the data gathering tasks can be used to optimize site selections. This past field season seven holes were drilled and cased, and heat flow determinations for them are in progress.

We are continuing to search for any avallable free holes and are currently negotiating with the Burlington Northern and Union Pacific Rallroads for permission to $\log$ temperature gradients in water wells along their tracks in Nebraska. We also expect to obtain two gas wells from Kansas-Nebraska, a natural gas exploration company, in western Nebraska.

\section{Discussion}

Figure 7 is a composite representation of existing data relevant to the geothermal regime of Nebraska. The zone of coincidence of the South Dakota thermal anomaly and the high gradient areas shown on the A.A.P.G. map for eastern and northern Nebraska lies along the trend of a zone of earthquakes (Docekal, 1970) in Nebraska. The strike of the earthquake zone coincides 
with a line connecting the offset segments of the mid-continent gravity high (Woolard and Joesting, 1964). Carlson (1979) suggested that the line of earthquakes follows the trend of a former transform fault which still represents a zone of weakness in the pre-Cambrian rocks of the basement. The fault zone is presently active for unknown reasons, but its existance has promising implications for the geothermal resource potential of the area. This section of eastern Nebraska will be carefully investigated during the course of our program. Much of western Nebraska appears to have good potential for lowtemperature geothermal resources and we plan to concentrate our efforts in the western part of the state on population centers. Future Studies.

The successful correlations between gravity lows and geothermal gradient highs (Costain, 1978; Hodge et. al., 1979) indicate that a Bouguer gravity map of Nebraska with a contour interval of one or two milligals would be a valuable tool for assement of the geothermal resource potential of the state. We are investigating sources of existing gravity data on Nebraska and hope to add the compilation of that data and acquisition of new data to to our program in the future.

The locations and nature of active faults in the eastern parts of the state are vaguely known. A microearthquake survey along the suspected fault zone could identify and locate active faults which could contain geothermal systems. We are considering adding a microearthquake survey to our program. A state-wide chemical geothermometry study would also be a valuable aid to our assessment program. Application of the silica, $\mathrm{Na}-\mathrm{K}$, and $\mathrm{Na}-\mathrm{K}-\mathrm{Ca}$ geothermometers to well waters around the state is being considered. 


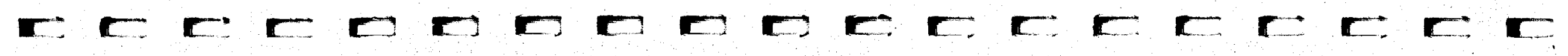

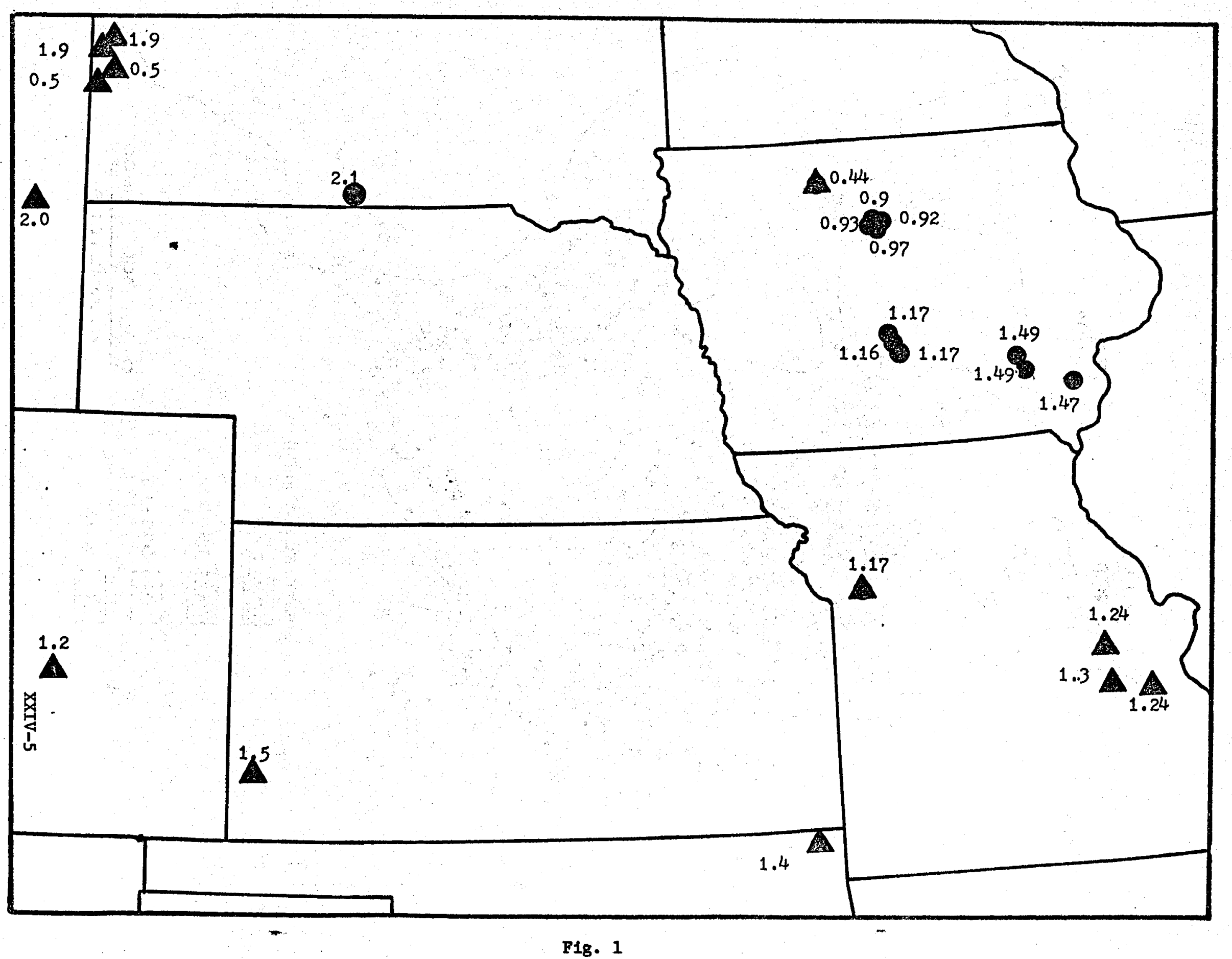




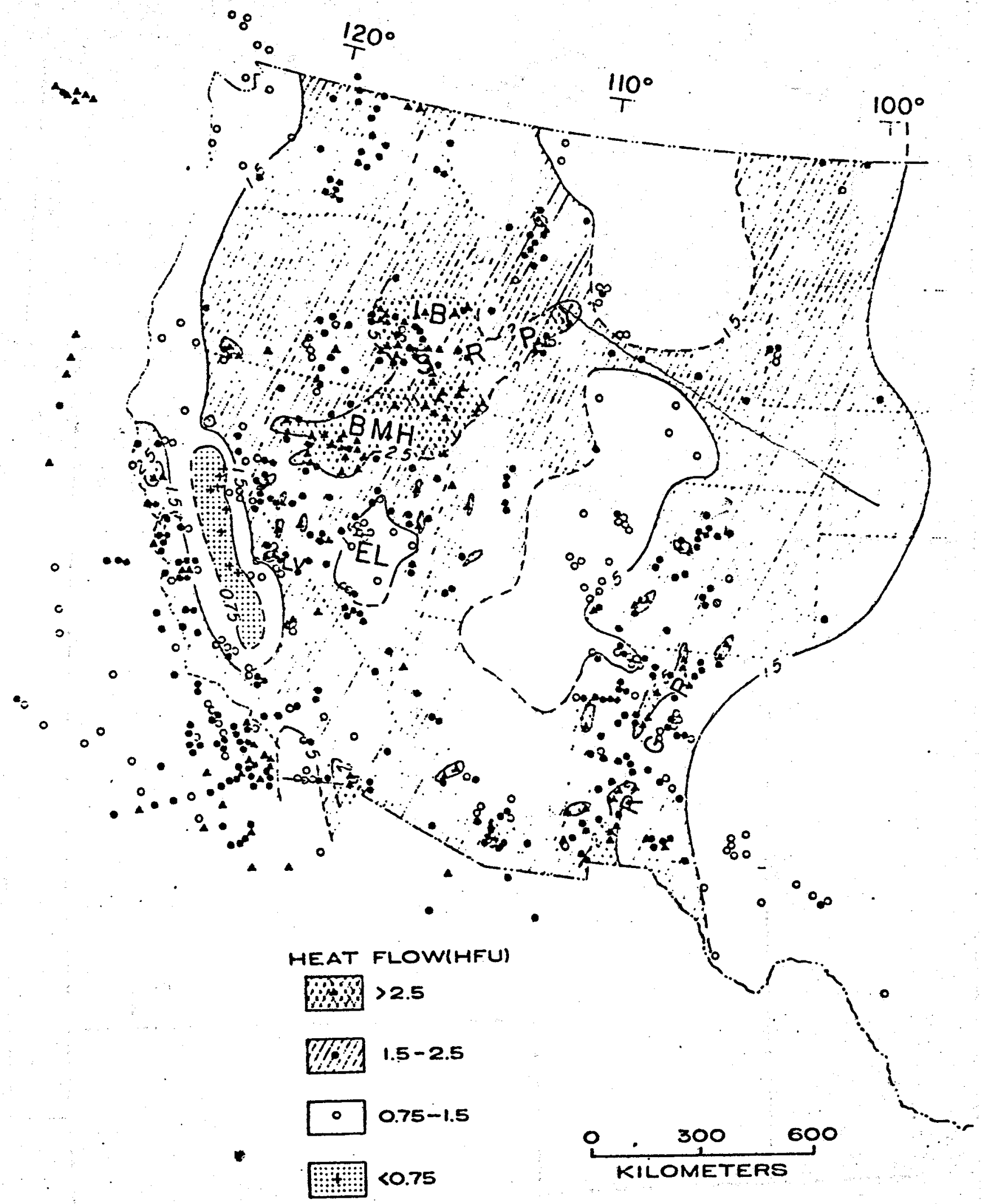

FI8. 2 


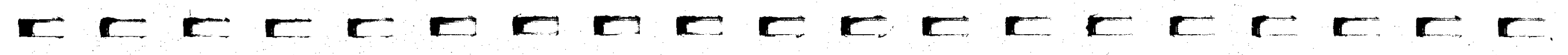

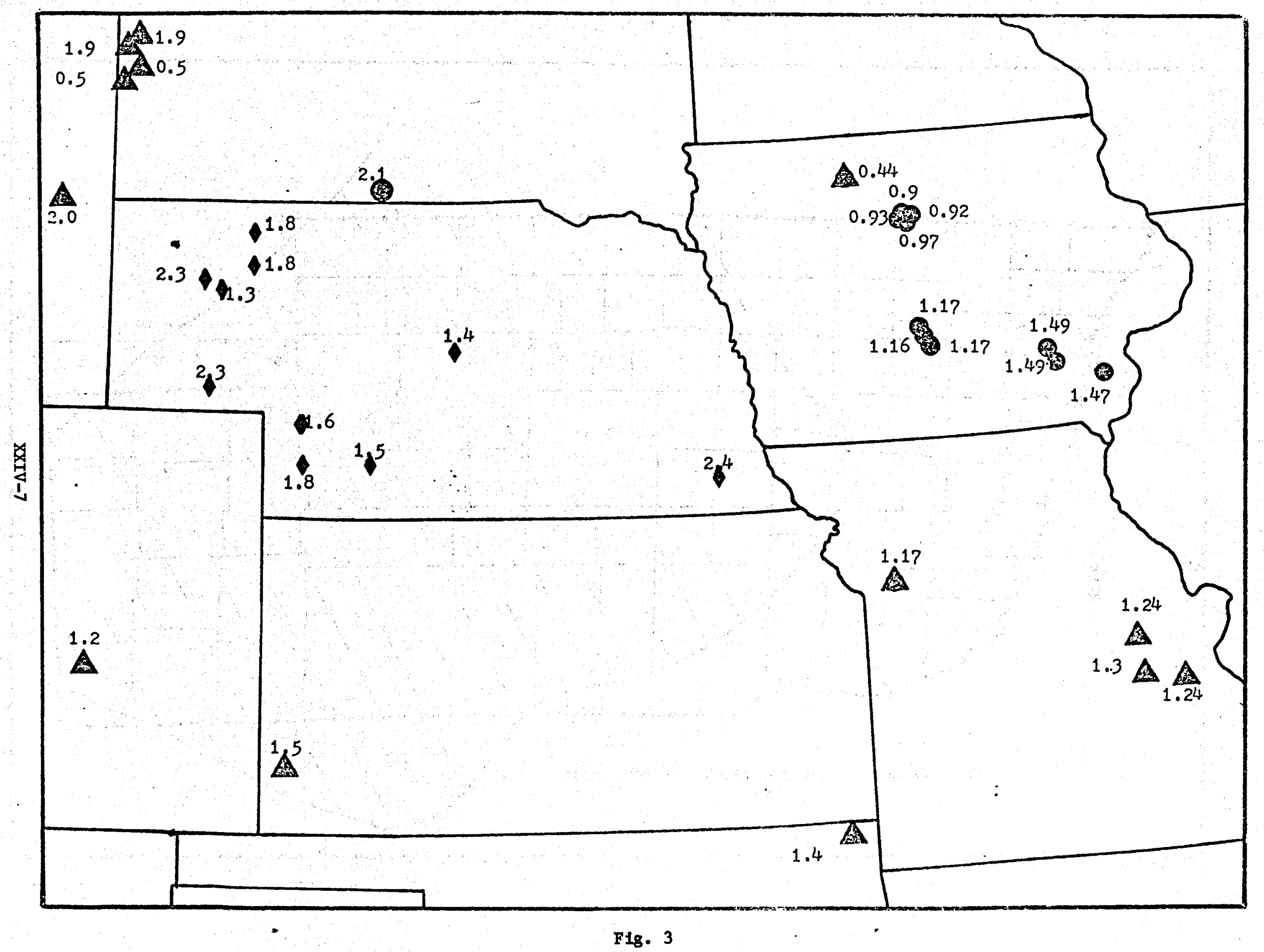




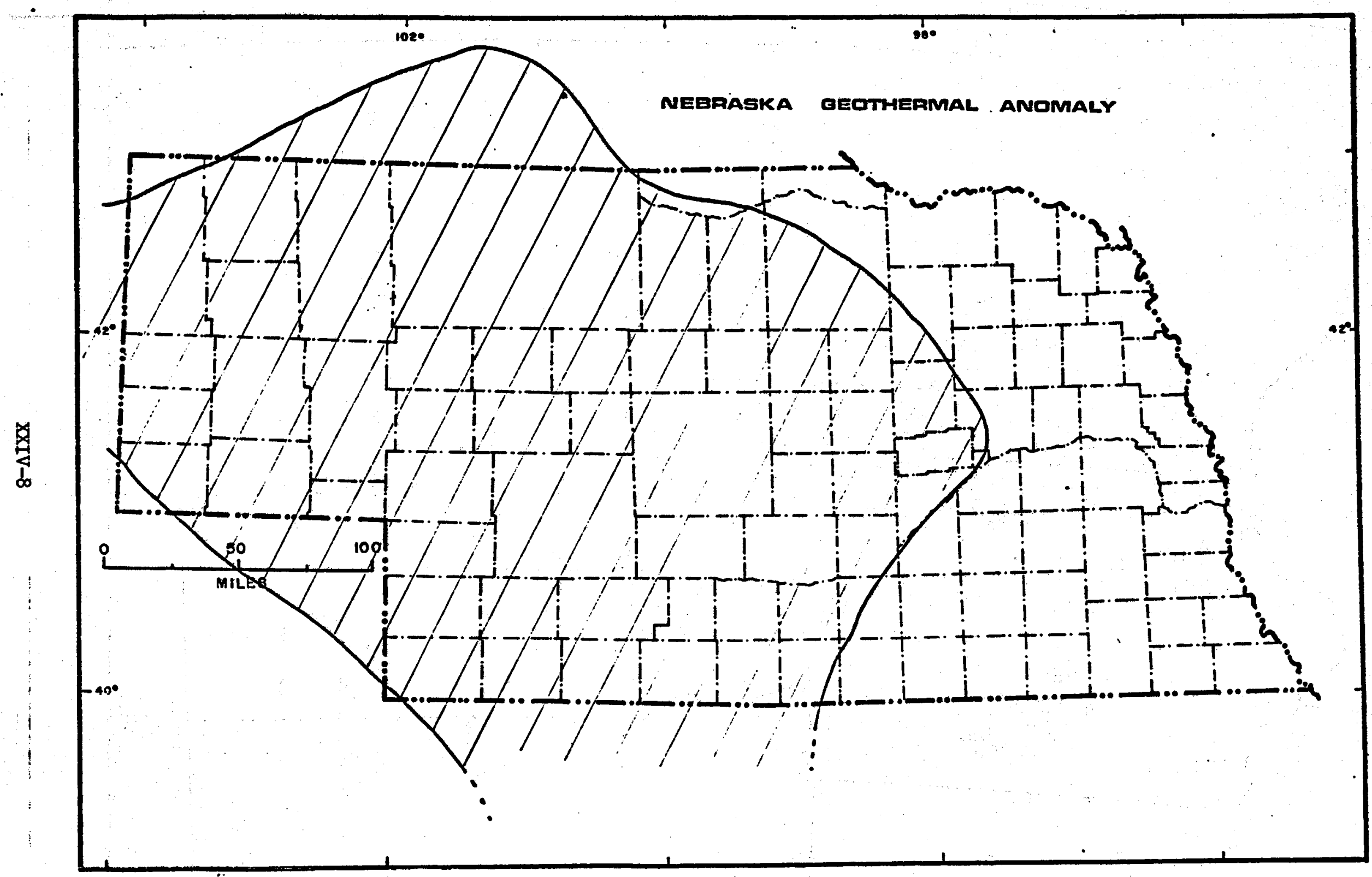

Fig. 4 


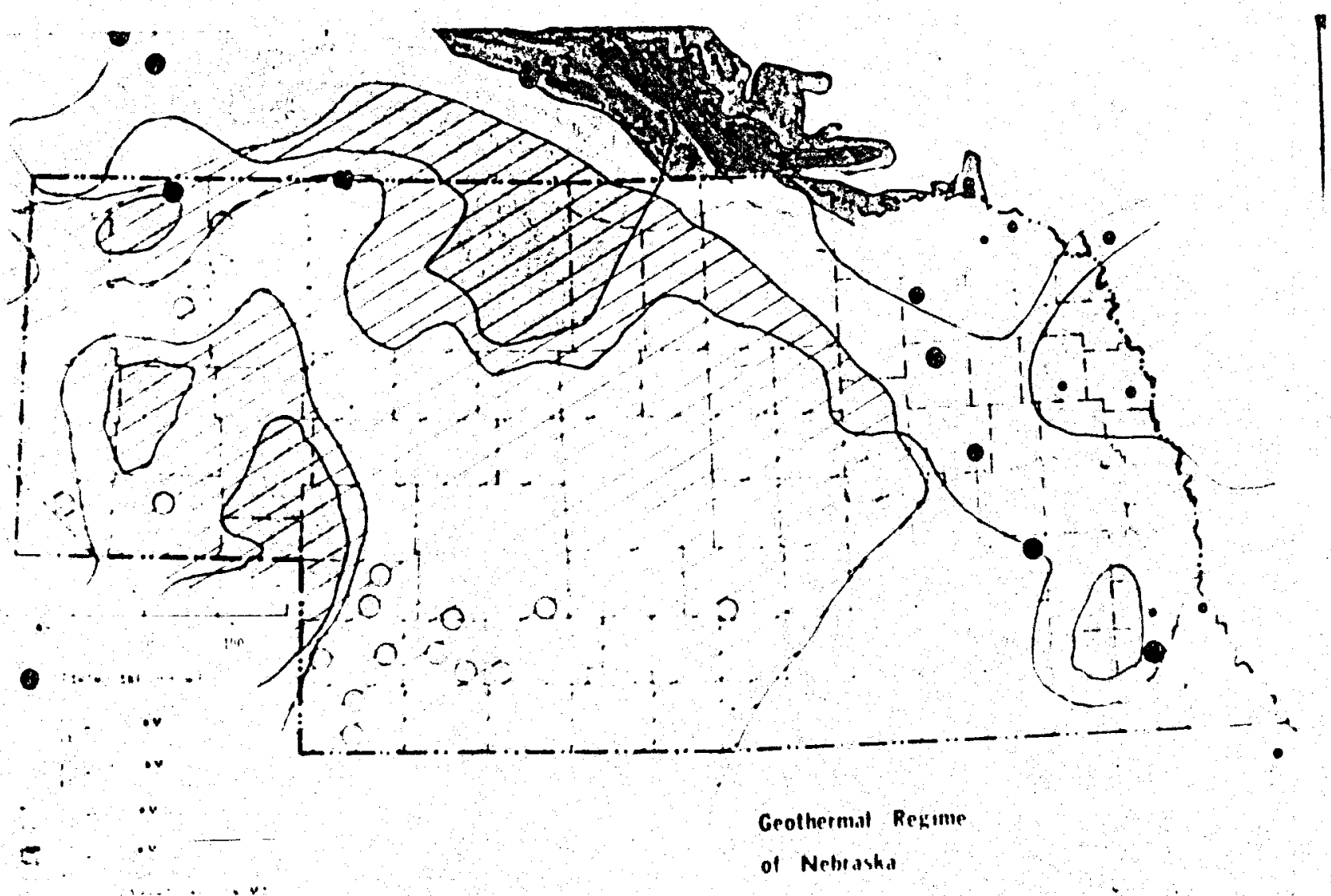




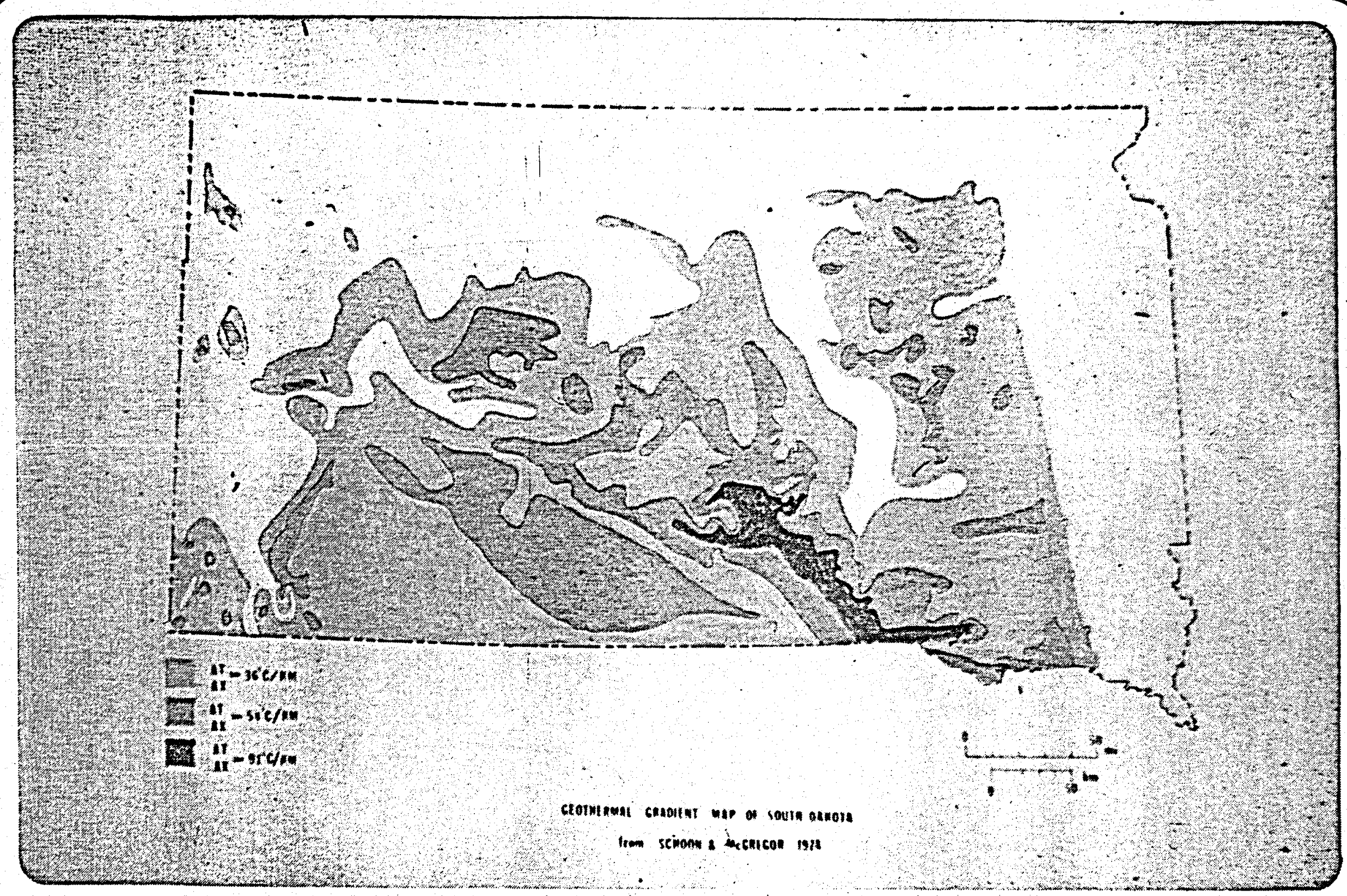




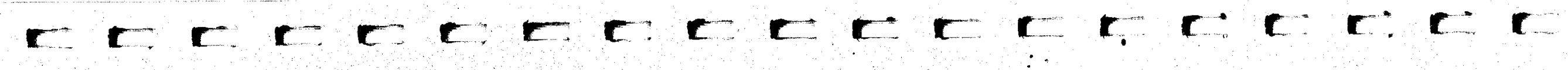

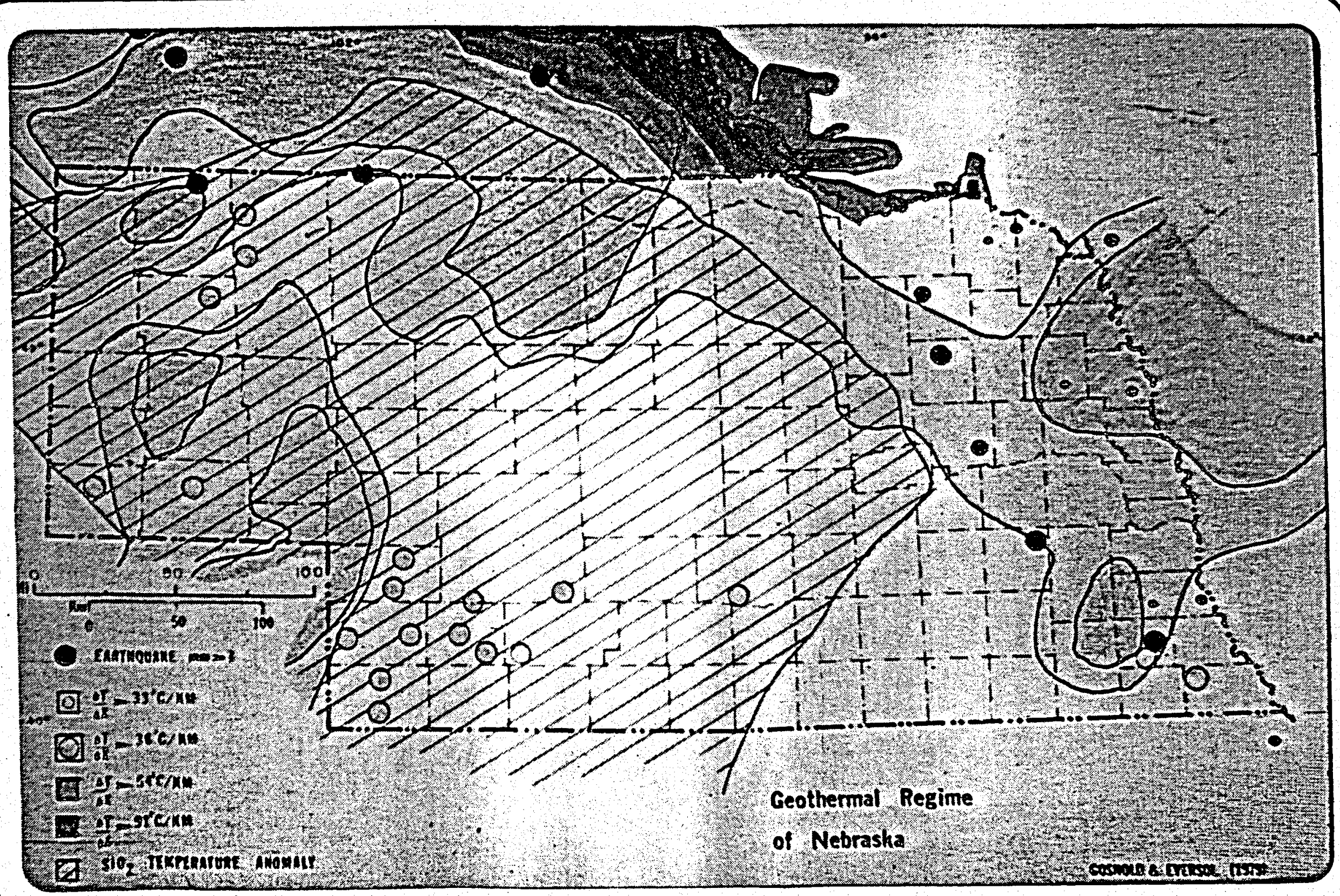


Geothermal Studies

Delaware

and

Comments Relating to Application

at the Town of Lewes

by

Kenneth Woodruff

Delaware Geological Survey 
GEOTHERMAL PROGRAM IN DELAWARE

Kenneth D. Woodruff

The Delaware Geological survey has recently completed the first year of a relatively modest program with DOE. The elements of the program included:

(1) Administrative assistance to DOE and its contractors in helping to pave the way for the test drilling in Delaware,

(2) temperature logging the DOE holes in the state,

(3) a gravity survey of primarily southern Delaware.

I'Il be discussing briefly the results of these last two items. Slide 1 - For about three years now, the DGS has been looking at the impact of possible offshore petroleum discoveries on the state. Our activities have included at least a preliminary assessment of available geophysical data in or close to the state. The common element in this assessment and in DOE's East Coast program has been the interest in the depth to basement or the thickness of the Coastal plain section. This slide shows the location of the project area (portions of the southern two counties) in relation to the offshore area and the BLM lease blocks of the last two sales. We have been attempting to relate the offshore data to our knowledge of the onshore geology with particular emphasis on determining basement depth and type.

slide 2 - There are no test holes that have penetrated basement rocks in southern Delaware. Shown here are the locations of the basement holes in adjacent states. There 
were three holes drilled near Bridgeville, DE in the 1930's for oil exploration but none of these reached basement. The deepest hole was only about 3,000 feet. DGS succeeded in locating one of these casings and was able to get a gamma log to 700 feet. The casing was blocked below this depth.

Slide 3 - These are the locations of the five 1,000 foot DOE test holes in Delaware. The numbers shown are the temperature gradients measured in degrees centigrade per kilometer. The normal temperature gradient as determined from previous measurements in other holes is about 1.1 degrees F. per 100 feet or about 20 degrees centigrade per kilometer. Clearly the highest gradient was in the Dover Air Force Base hole. The lowest gradient was in the hole at Iittle Assawoman Bay. Note however that hi. than normal gradients were measured here at Bridgeville and at Redden State Forest.

slide 4 - This map shows Bouguer gravity values contoured every 5 milligals. Our gravity stations were run with a Worden meter using elevations from the standard UsGS topographic maps as control. The elevation control was probably the greatest source of error.However this was a reconnaissance study and neither time nor funding would permit precise leveling. About 350 stations were established in eastern sussex and southeastern Kent Counties. Actual 
station spacing worked out to be about one-half to three quarters of a mile. In addition VPI provided to us all of their compiled data for the Delaware area, including some stations they ran in the Bridgeville area.

Note the relative gravity low centered around Bridgeville and the gravity high in the Bethany Beach area.

Slide 5 - Detailed gravity map - This is the same data contoured at one milligal intervals. The locations of the DOE test holes are also shown on here in red. Note that the Bridgeville hole falls nearly in the center of this gravity low and that the temperature gradient here was indeed well above normal. The Dover hole was drilled in an area of a relative gravity high and had the highest gradient as already seen. There is the suggestion of some basement structure from the gravity data but the control here was not as great as in the southern part of the state. The Dover area would seem to have some geothermal potential from just the gradient alone. However, the depth to basement at Dover is estimated at only about 2,500 to 3,000 feet which would give a bottom hole temperature of about $127^{\circ} \mathrm{F}$.

slide 6 - The local gravity values tie in very nicely with the regional trends as shown on this slide. It might have been tempting to consider the low around Bridgeville as an isolated situation however it appears to be part of a rather 
distinctive trend shown here. The high in the Bethany Beach area also confirms a high mapped by others immediately to the south in Maryland. Sabet (1977) referred to it as the "Ocean City high." Other authors have pointed out that this high corresponds to a center of sediment deposition.

Slide 7 - In 1976 Spoljaric and others used this

Landsat photo to identify linear features in a study of the structural evolution of the Delmarva Peninsula and adjacent areas. They noted that the alignment of this stream valley (feature no. 12) in southwestern Delaware and its extension to the northeast formed a prominent linear but could not. determine if the location of the valley was structurally controlled.

Slide 8 - This sketch map shows the linears identified from the Landsat imagery plotted on a map of the Delmarva peninsula. The linear discussed above, show good coorelation with the alignment of the axis of the gravity low seen in slides 5 and 6 . This at least suggests that the present day stream valley may indeed by structurally controlled.

In 1906 NOAA indicated a felt earthquake in the Seaford, $D E$. area, on the southwestern portion of the linear. A DGS seismic station located in Georgetown, a few miles east of sĚaford, has recorded about six small, local events in the last two years. The epicenters cannot be located with any precision as only the Georgetown station recorded the events. 
Slide 9 - Earlier, it was mentioned that DGS had been accessing geophysical data from the offshore areas near Delaware and attempting to determine basement depth.

This map indicates the location of the seismic lines used in this assessment. The lines are either public lines run for the USGS or speculative data which we have purchased. One profile indicated on this slide was contracted for directly by DGS and the USGS in a joint program. The program was part of a resource assessment of nearshore Delaware made by the DGS. The 24 -fold, CDP, high resolution sparker survey began at the mouth of the Capes just inside Delaware Bay, ran south to a point off Ocean City, Maryland, and then east to tie into USGS Line 10.

Slide 10 - This is an example of the data for the northernmost part of the reflection profile just described. There is no clear reflection from basement. However, nearly all of the unquestionable reflections could be correlated with known stratigraphy.

slide 11 - This is the southernmost part of the same profile. Again, we have difficulty picking basement reflections. Eventually, we were guided more by the quantitative character of the record than by specific reflections. Slide 12 - A tentative interpretation of this profile indicates a rather uneven basement with an apparent southerly 
dip and dropping off quite sharply in the southern part of the state. "Basement" as labeled on the slide, may not be crystalline basement, but could be something quite younger. Slide 13 - This is a map of the depth to crystalline basement made by contouring what we consider reliable picks on crystalline basement from all other sources. Note that the 3 kilometer line (about 9,800 feet) passes through Lewes. This indicates that on the DGS seismic lines described earlier crystalline basement was not identified.

Slide 14 - We have speculated what a cross-section to, and including crystalline basement might look like from the northern part of the state extending southeast onto the shelf as indicated here.

Slide 15 - This is highly diagrammatic but illustrates our conclusions from all of the available data. Border faults in possible Triassic age rocks may extend into the basement and could be paths for circulating fluids. This is not inconsistent with the observations from the Bridgeville area for instance, but is strictly conjecture. However, the important point is that we really don't know what's down there at any great depth. At the very least we need some seismic cross-sections backed up by a couple of basement holes. If we're really going to prove the existence of a geothermal resource beyond that of the normal gradient eventually we'll need that kind of deep data. 


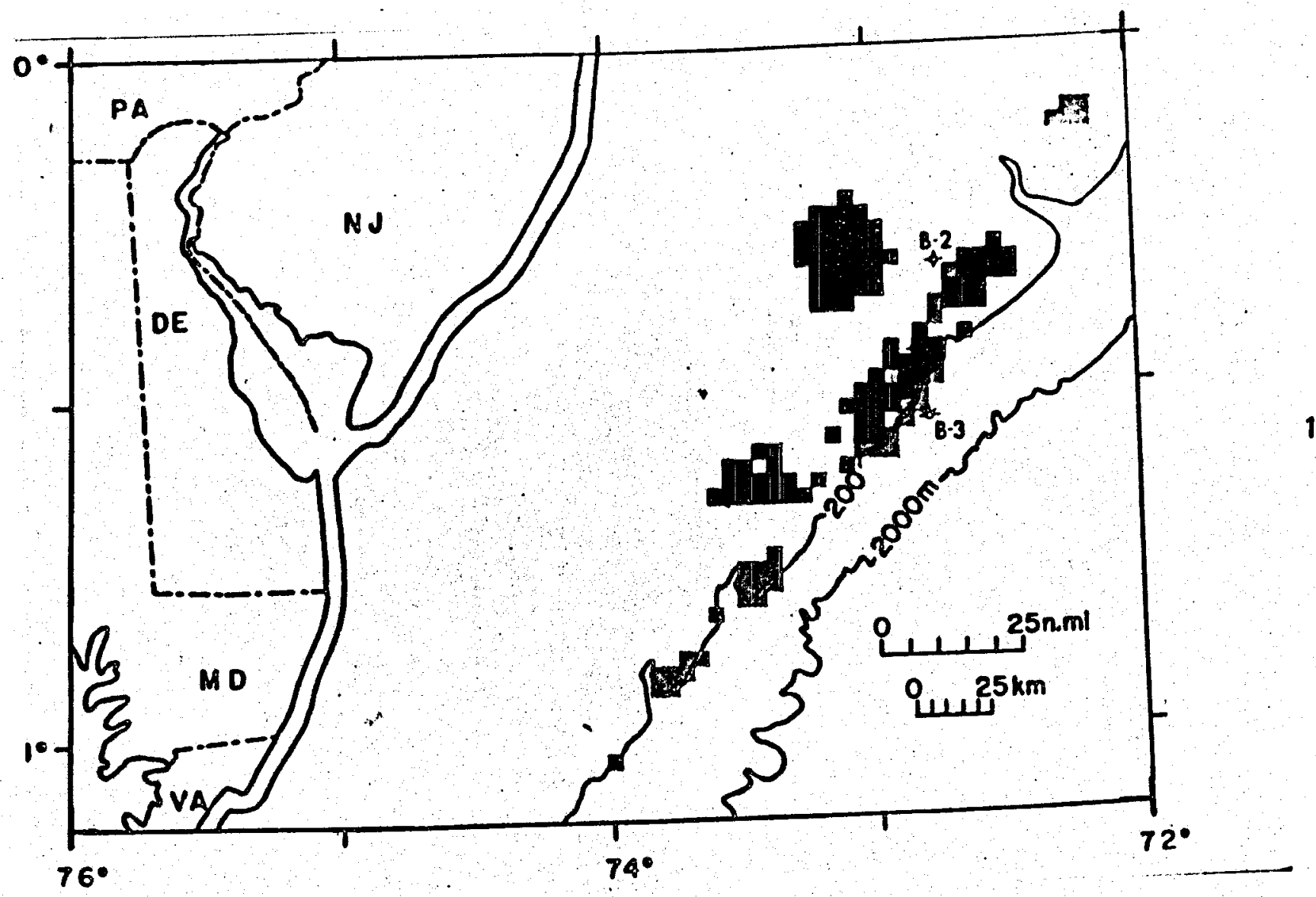

$b$

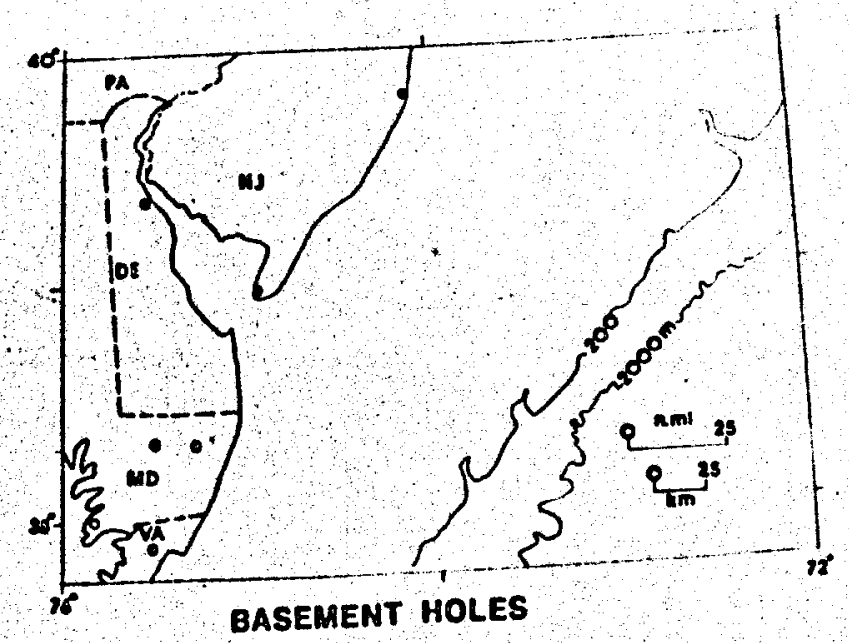





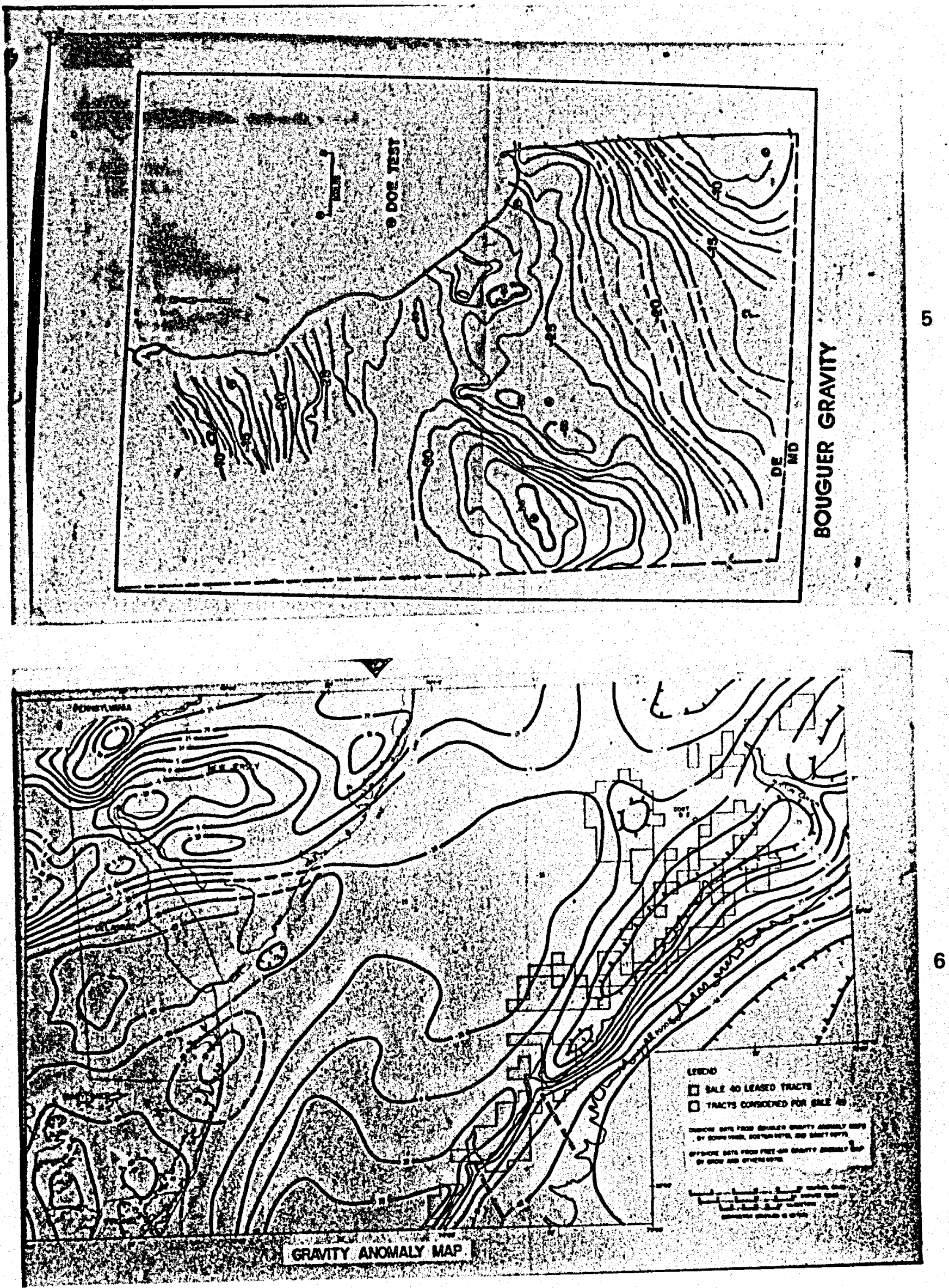



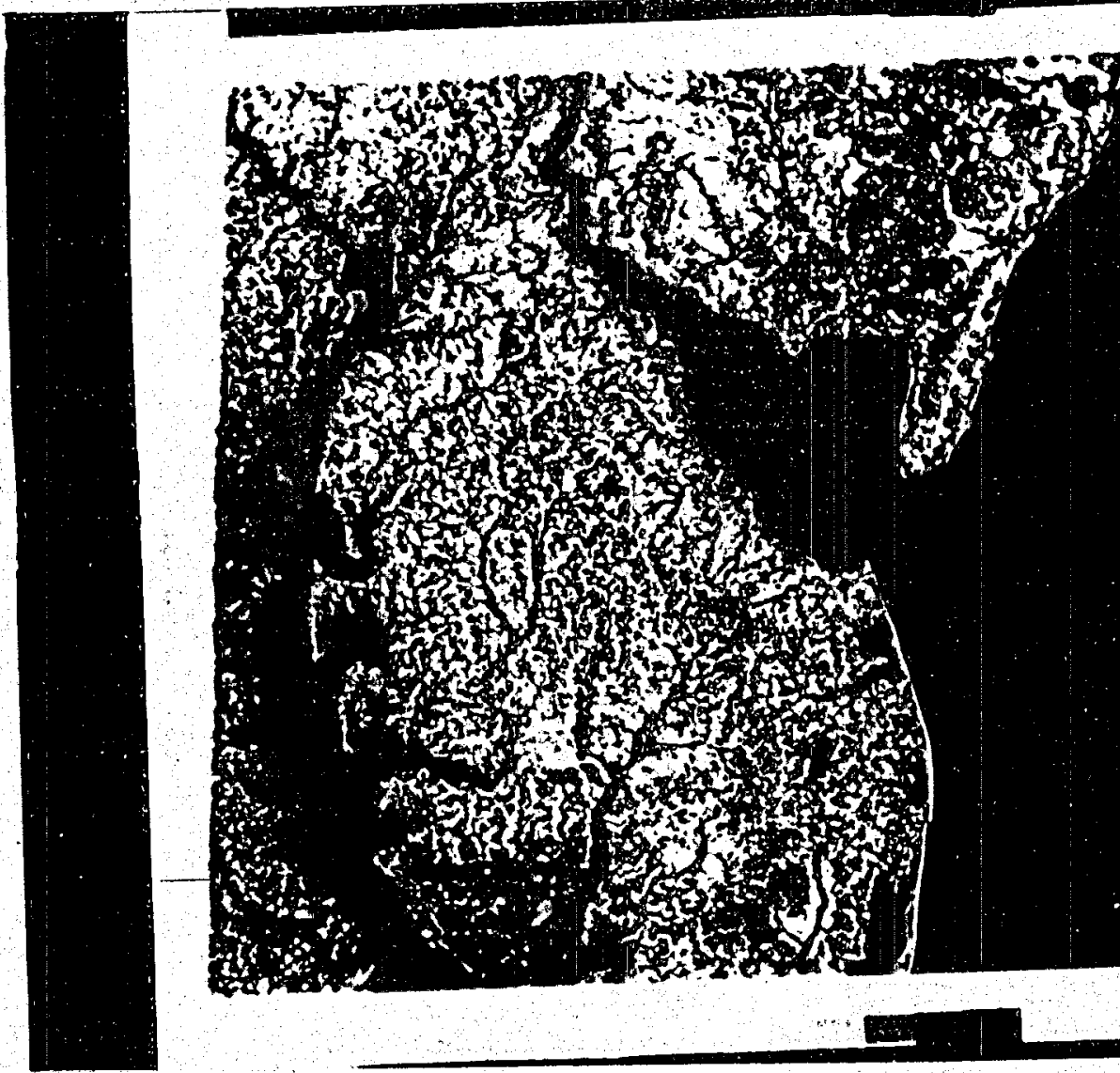

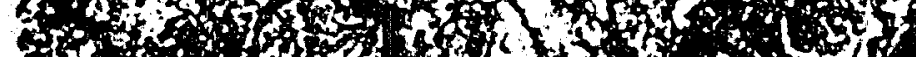

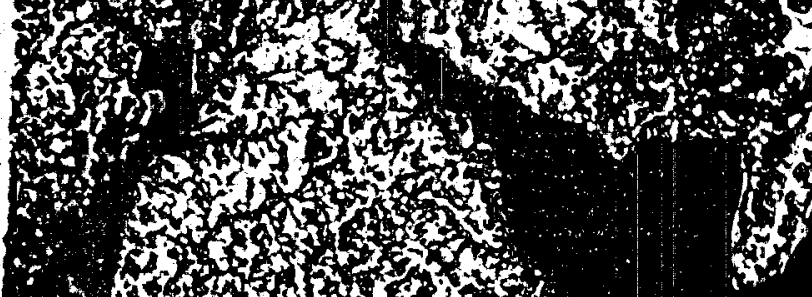

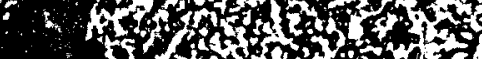
$\rightarrow 20,2010$

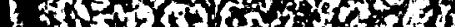

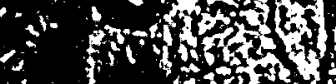

Axpitsing

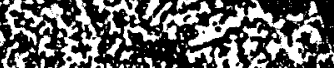

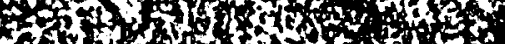

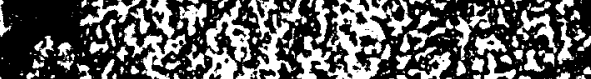
3.

t:

ax:

His.

$+3$

ats. if

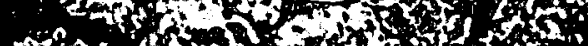

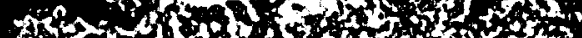
Atophes? it)

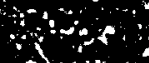

$\$$
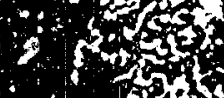

ats

$\left.14 x^{3}\right)$ 

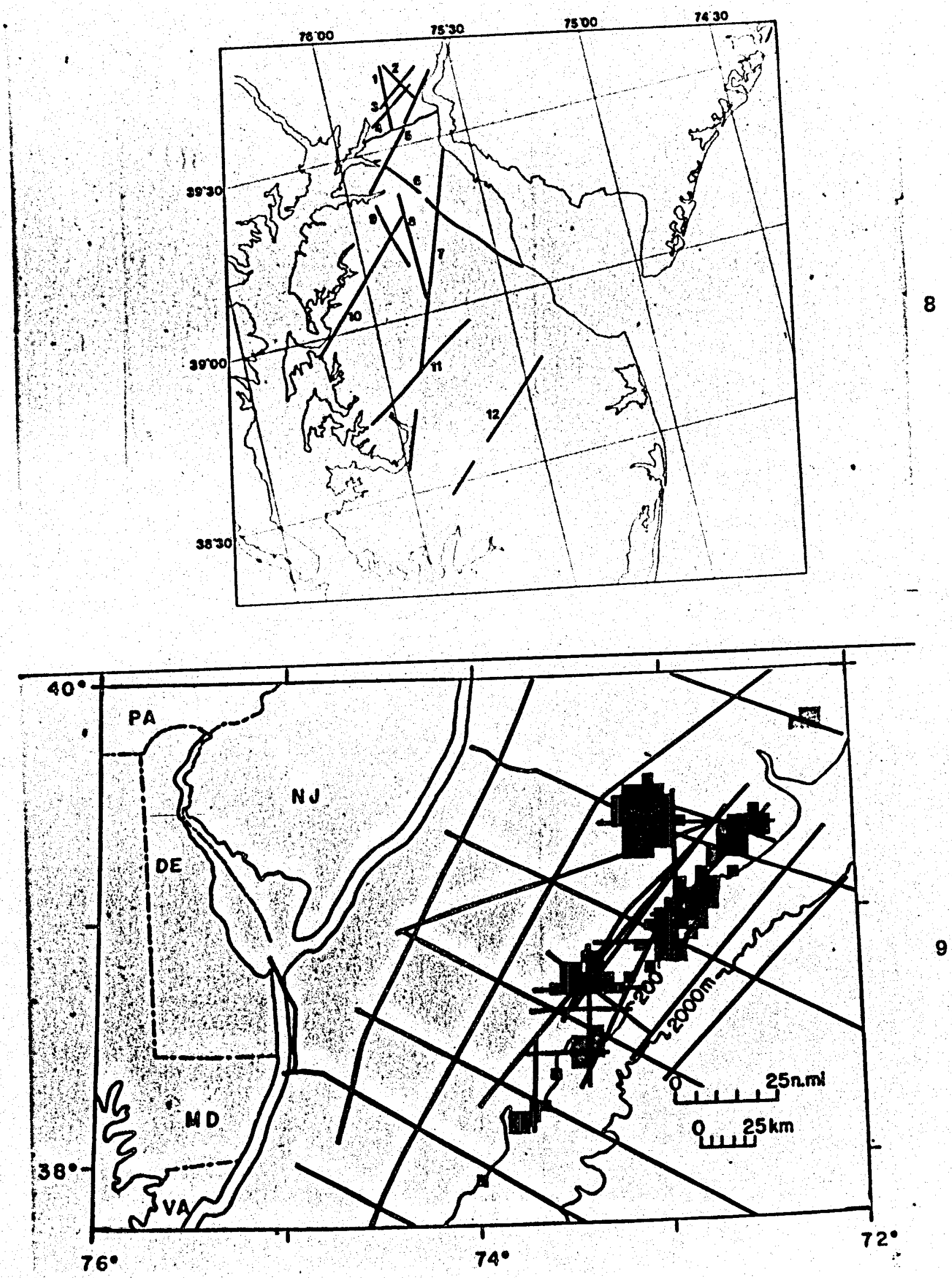


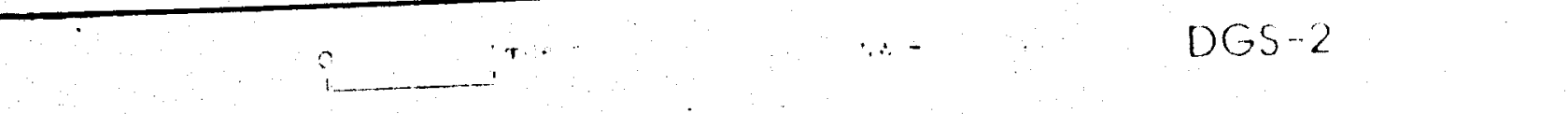

(1)

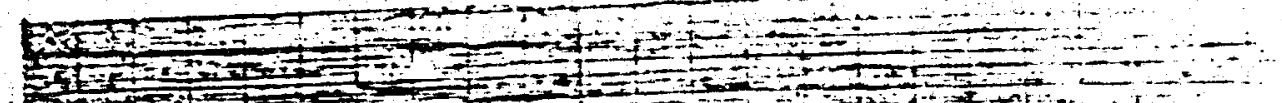

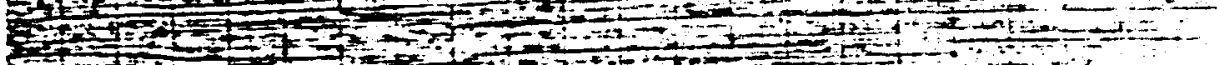

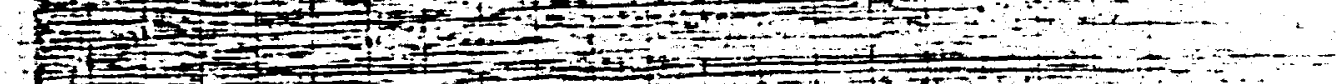

120

(3)

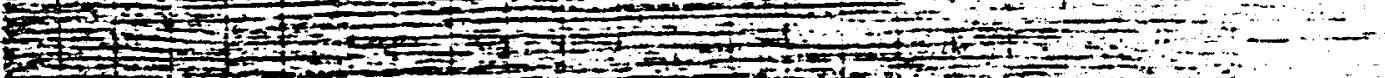

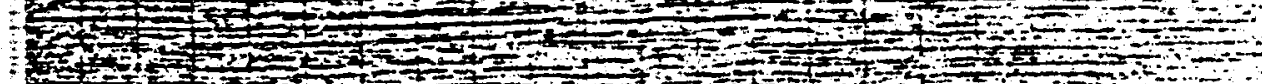

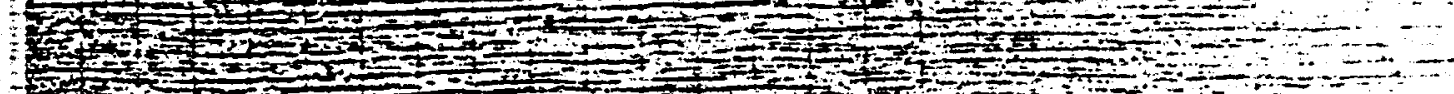

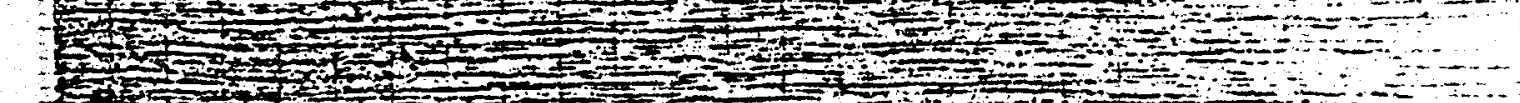

(1)

2

标

(2)

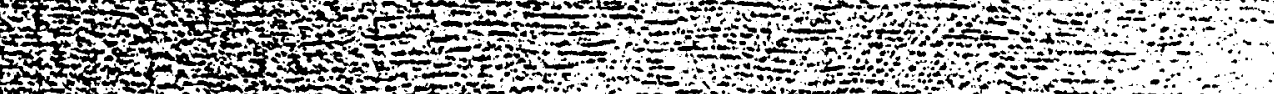

(a)

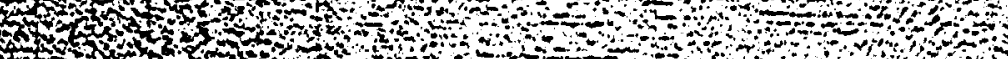

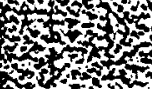

0

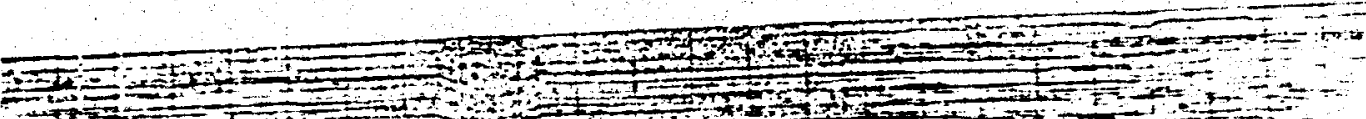

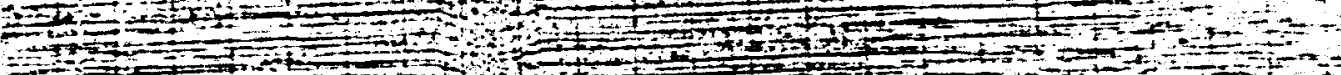

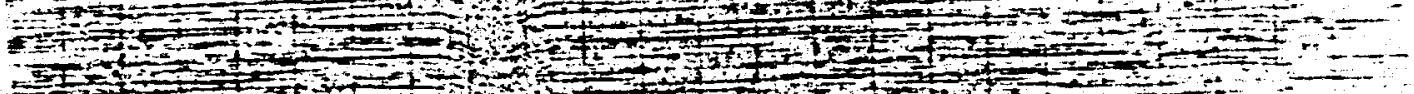

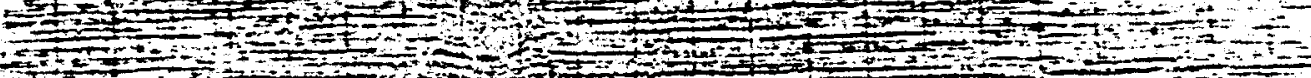

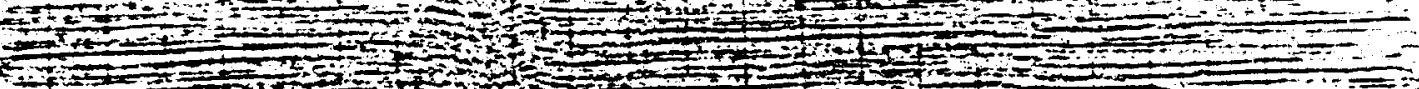

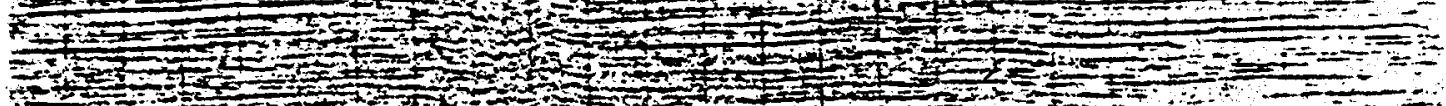

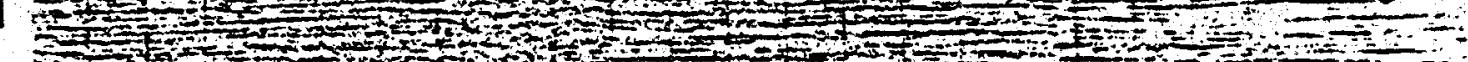

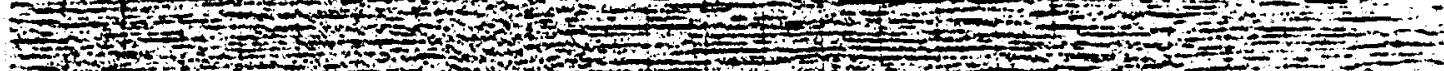

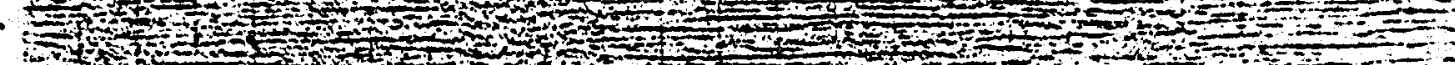

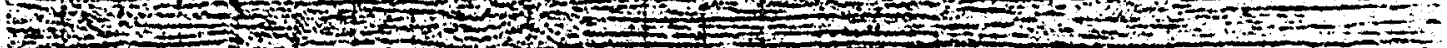

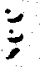

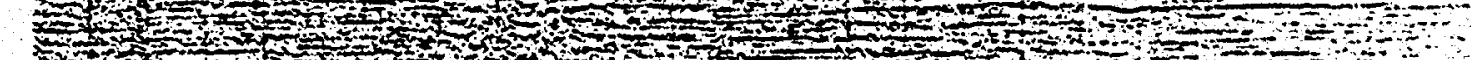

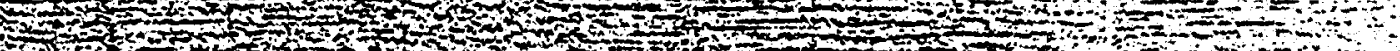

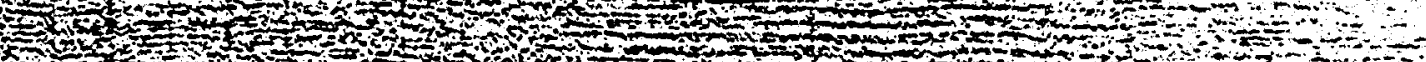

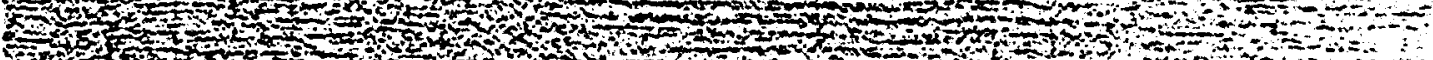

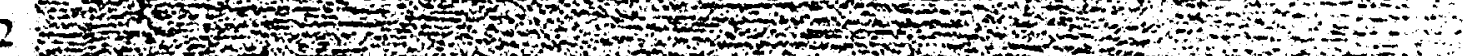

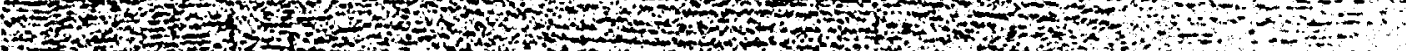

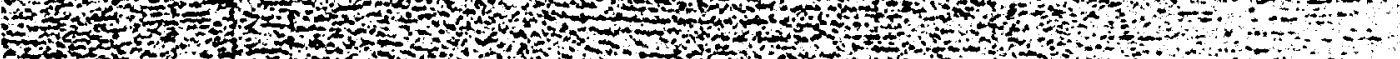

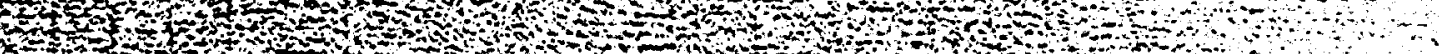

H.

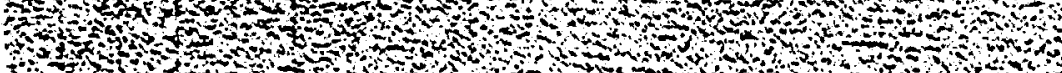

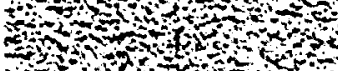

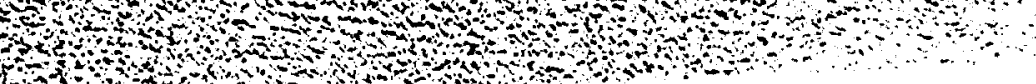



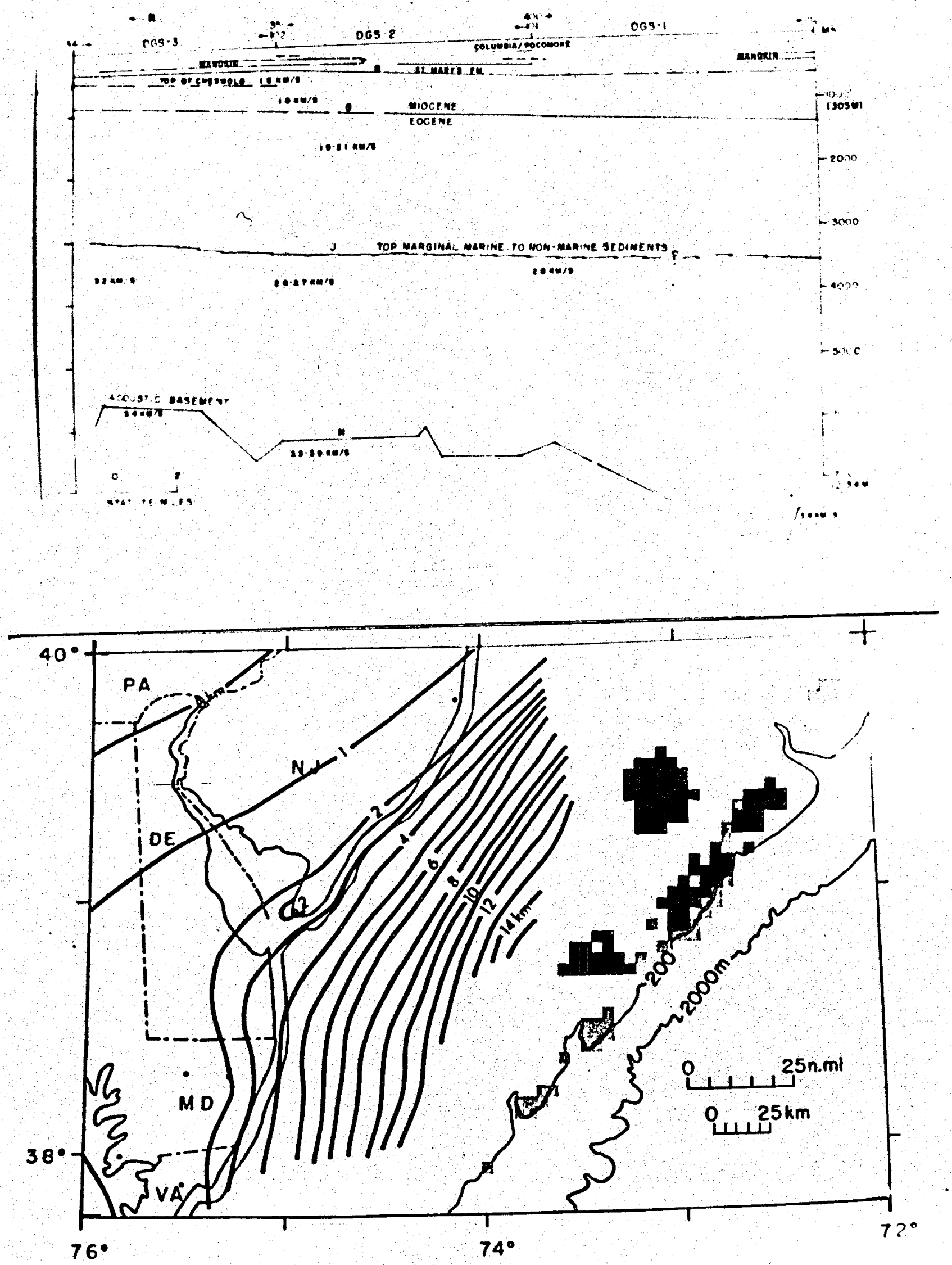


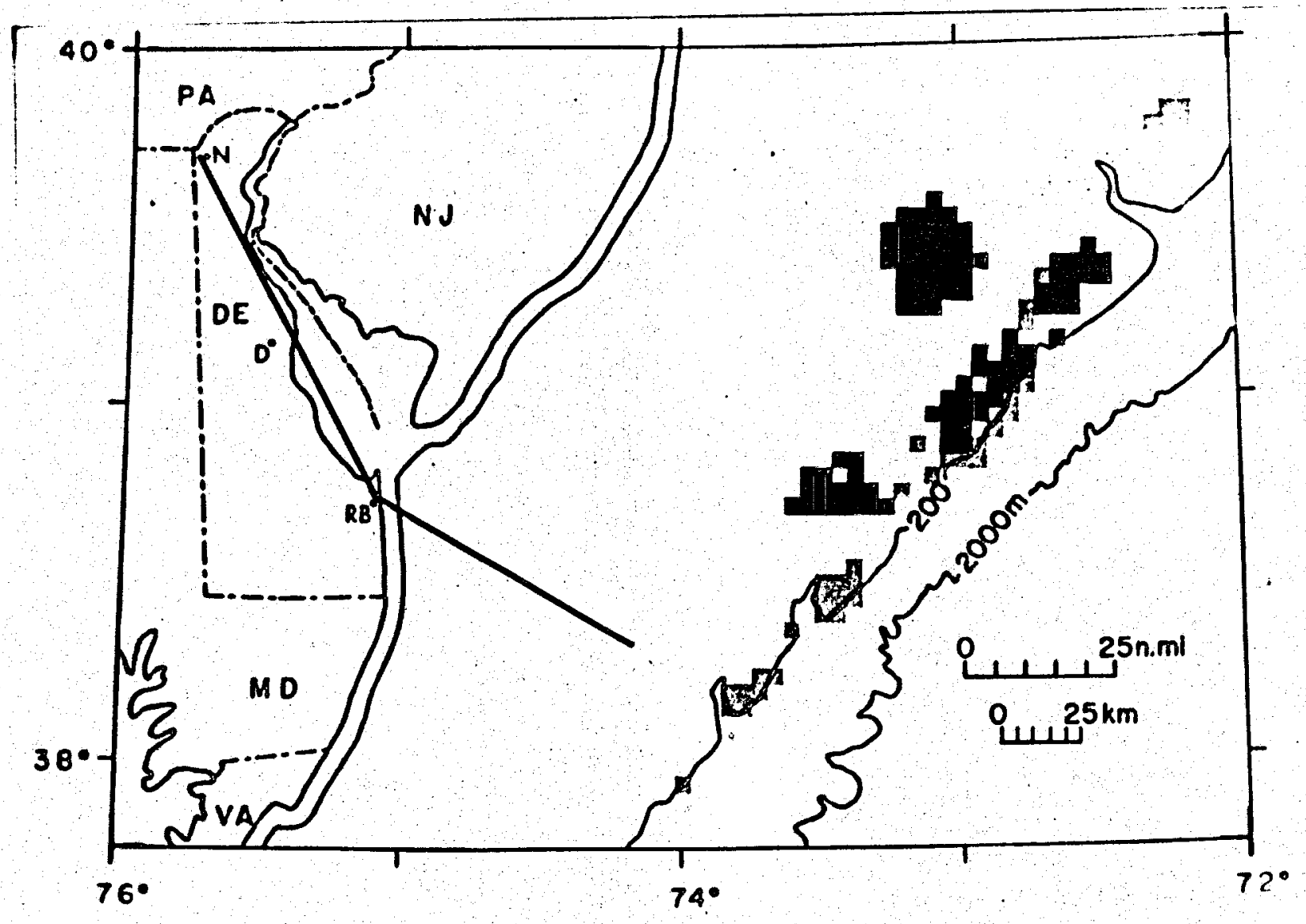

14

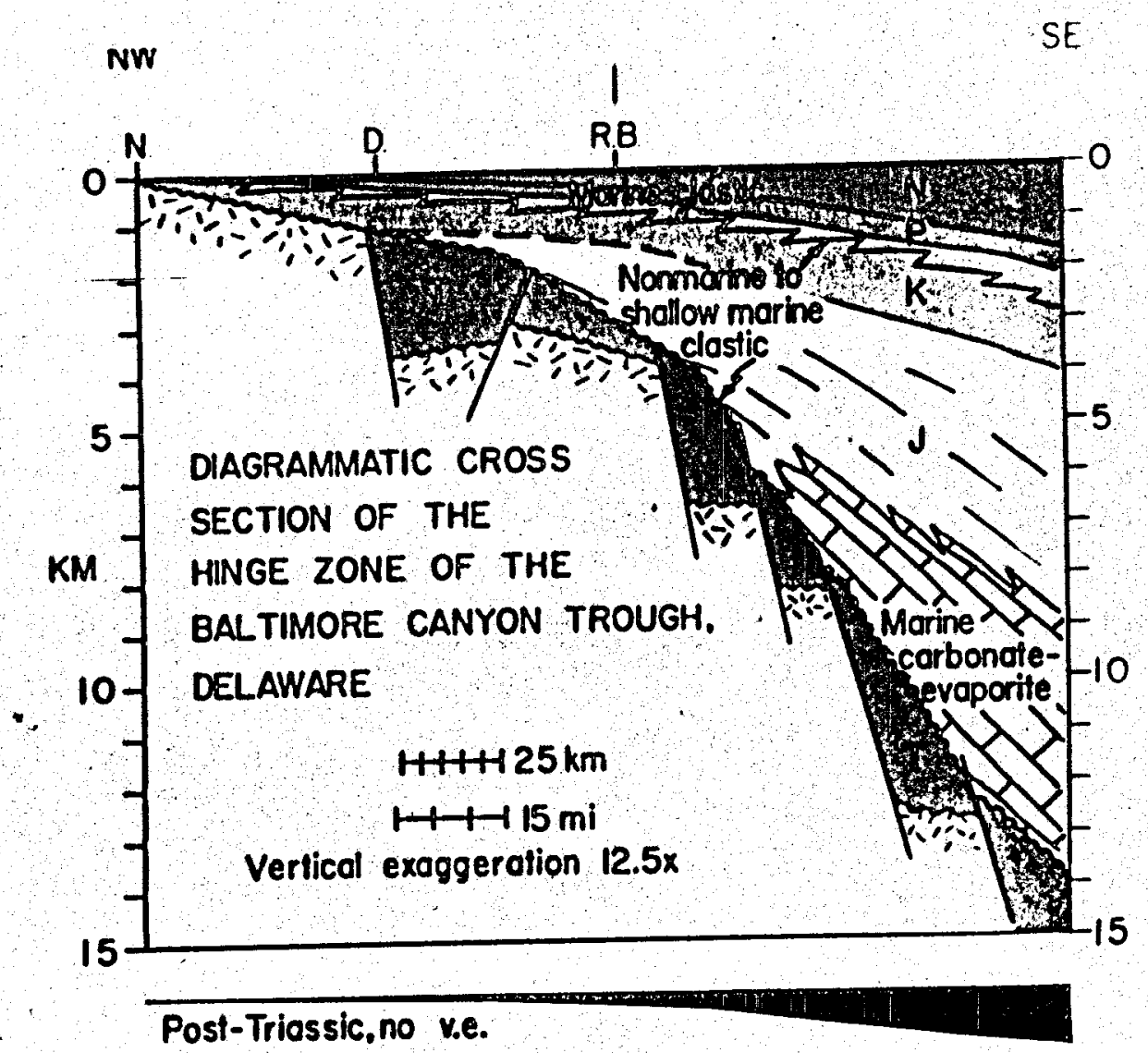




\section{Comments on Potential Geothermal Energy}

Developments in Lewes. Delaware*

The town of Lewes, Delaware is assessing the potential of developing moderate temperature hydrothermal geothermal energy for a rather varied group of potential users, all located within approximately $\frac{1}{2}$ mile area. Fig. 1 lists the potential users and the application desired by each. Fig. 2 shows the location of each potential user in relation to the town of Lewes. The developer of the resource and the operating entity supplying the geothermal energy would be the Board of Public Works of the town of Lewes.

Inquiries should be addressed to:

Mr. John P. Curtin

General Manager

Board of Public Works

P. O. Box 518

Lewes, Delaware 19958

* Mr. John Curtin could not attend. Therefore, this summary was written by Mr. F. C. Paddison 


\section{POTENTIAI APPLICATION OF GEOTHERMAL ENERGY - LEWES, DE.}

1. Space heating - Beebe Hospital

\section{Schools}

2. Chemlcal and thermal recovery from geothermal water - Barcroft co.

3. Heating water - R\&D commercial mariculture - University of Delaware

4. Heating cleanup and process water - revitalized Iish Industry -

- Fisher corp.

5. Geothermal energy provided by Tuwn of Lewes Board of Public Works 
THE JOHNS HCPKINS UNIVERSTYY APPLIED PHYSICS LABORATORY

LaURel. MarYlano

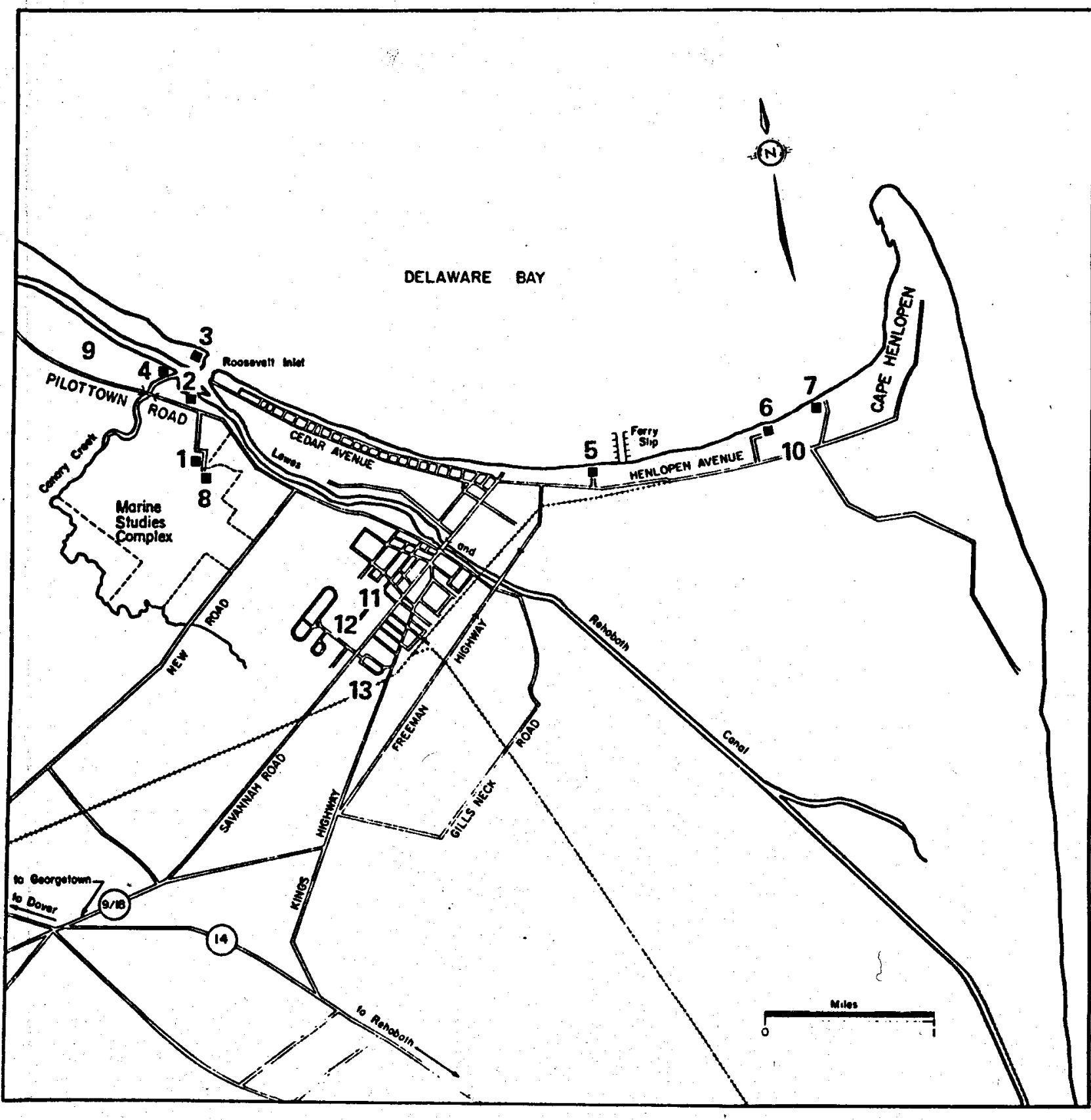

MAP OF LEWES

University of Delaware, Marine Studies Complex

Lewes, Delaware

(302) 645 - 4000

1. Main Offices/Cannon Lab

2. Marine Operations Building

3. Bayside Lab

4. Pollution Ecology Lab

5. Coast Guard Dorm

6. Sea Grant Mariculture Lab

7. Henlopen Lab and Men's Dorm
8. Site of new Mariculture Lab (completion expected in late 1978)

9. Doxi

10. Barcroft Co.

11. Beebe Hospital

12. Elementary and Junior High Schools

13. High School 


\title{
Geothermal Studies
}

\section{Alabama}

\author{
by \\ T. L. Neathery \\ Geological Survey of Alabama
}

$x \times v^{\prime}$ 


\section{ASSESSMENT OF THE GEOTHERMAL/GEOPRESSURE \\ POTENTIAL OF THE GULF COASTAL PLAIN \\ OF ALABAMA: A PROGRESS REPORT}

By

Thornton L. Neathery

Gary V. Wilson

Geological Survey of Alabama

E.A. Mancini

D.J. Benson and

George C. Wang

University of Alabama

\section{INTRODUCTION}

Geothermal and geopressure zones are known to occur in the northern Gulf of Mexico basin and along the Atlantic continental margin beneath Tertiary and Quaternary sediments. Definition and assessment of the potential geothermal and geopressure resources have recently begun in Alabama.

More than 1,900 wells have been drilled in search of petroleum and natural gas in Alabama since 1944. Of the vast quantities of data available on the subsurface conditions in Alabama, only a small fraction has been published in summary form, and none is known to assess the geothermal and geopressure potential of the region. Available information on geologic structure, stratigraphy, sand thickness, and bottom-hole temperature and pressure is deemed adequate for an initial evaluation of the geopressure/geothermal potential in the state. Hydrologic data are somewhat less adequate, 
but a great deal of information is available on porosity, permeability, and salinity of the major aquifers.

Some data are available on the spatial orientation of the stratigraphic units with respect to geologic structure, the limits of the buried Triassic basin and its possible attendant heat flow, and the location of buried major structural features.

The objective of our current research, therefore, is to bring together all available data into a comprehensive subsurface geologic data base for the identification and interpretation of potential geothermal and geopressure anomalies in the Gulf Coastal Plain of southern Alabama.

\section{GEOLOGIC SETTING}

The area of the Alabama Gulf Coastal Plain exceeds 60,000 square miles (Fig. 1); however, the area of geothermal-geopressure potential is less than 45,000 square miles. This area of geothermalgeopressure potential can be divided into two parts, the area east of the Wiggins Uplift and the area west of the Wiggins Uplift (Fig. 2). The area east of the Wiggins Uplift is underlain by Mesozoic volcanic rocks that not only may contain hot-dry rocks but also may have rock units of low thermal conductivity overlying the Mesozoic strata. In this area are flowing hot wells that apparently tap waters of the deeply buried Tuscaloosa Group. other geothermal phenomena in the area include abnormally high bottom-hole temperatures and the presence of highly metallic brines in scattered oil tests.

West of the Wiggins Uplift is the eastern margin of the Mississippi Interior Salt Basin. To date the study of geopressure and geothermal features in the Gulf Coast Province has been concentrated in this area and has dealt primarily with Tertiary 

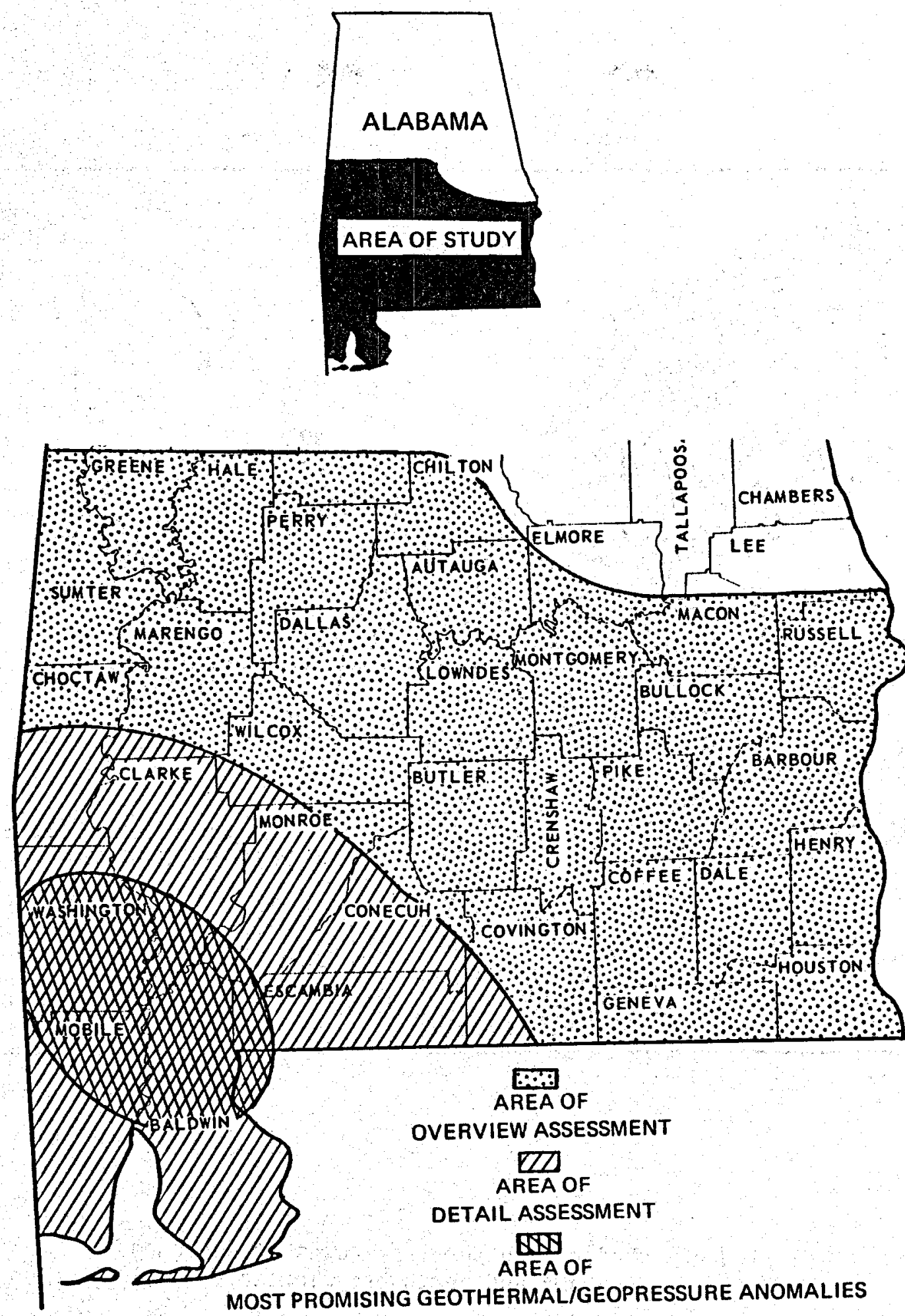

Figure 1: General area of study. 


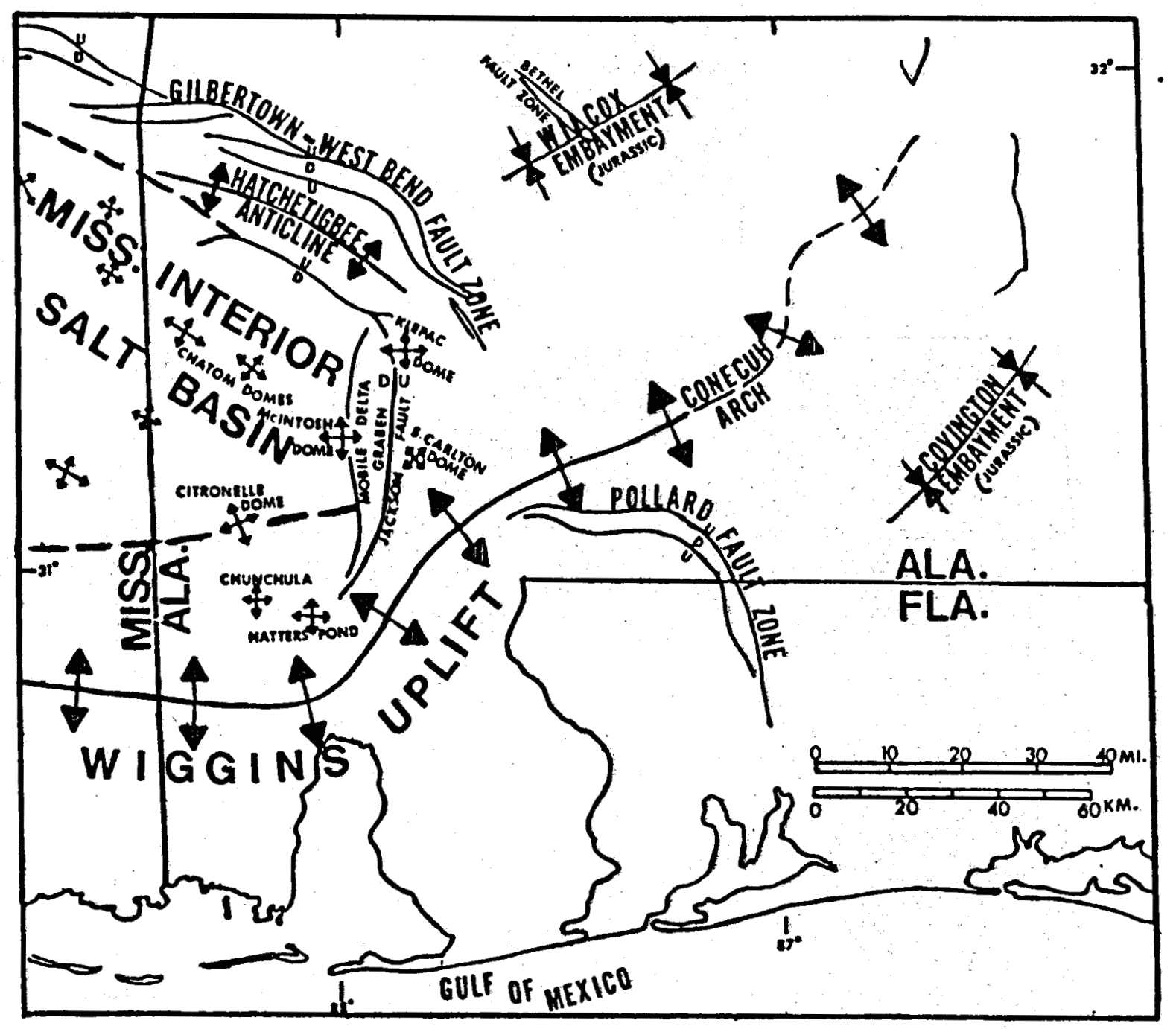

Figure 2: Major structural features of southwest Al abama and northwest Florida. 
clastics. Geopressure and geothermal studies in Alabama have focused on the older Jurassic formations (Smackover carbonate and Norphlet sandstone) in the Mississippi Interior Salt Basin and the possible igneous intrusions in the basin area. Here, the geothermal gradient is known to be erratic, with local hot spots. The origin of some of these hot spots has been correlated with the occurrence of igneous intrusions. The maintenance, enhancement, and degradation of the geopressure within the reservoir appears to be controlled by the initial porosity and permeability of the host sedimentary rock and its mode of diagenesis. The abundance of carbon dioxide, methane, and hydrogen sulfide gases in many of the developed reservoirs indicates possible mechanisms for geopressure anomalies. In Alabama, the Jurassic reservoir pressure appears to be controlled by the overlying impervious anhydrite seal.

There are a number of salt domes or suspected salt domes in southwest Alabama. Also, salt beds have been penetrated in a number of deep oil test wells. Salt flow has been recorded in some of these tests. Geopressure anomalies appear to be more common in this region as indicated by increasing mud weight, resistivity and acoustic data reported from oil tests. However, the highest geopressures are currently south of the Wiggins Uplift in Baldwin County. Hot brines are also known to occur in this area and could indicate a possible geopressure-geothermal system.

Although the foregoing is only a short synopsis of the geologic phenomena related possibly to geothermal and geopressure resources in the Alabama Gulf Coastal Plain, it does provide an intriguing data base for our studies. The geothermal-geopressure resource assessment of the Alabama Gulf Coastal Plain is proposed 
as a series of projects that may be performed independently of each other but are each directed towards a better understanding of this phenomena. By using a project-oriented approach to an assessment study, flexibility is maintained in order to respond to new data and developments.

SCOPE OF PRESENT WORK

In January of this year, the Geological Survey of Alabama, in a joint effort with the University of Alabama, Initiated a study of the geothermal and geopressure potential of Alabama. This study is being made possible by funds provided through the U.S. Department of Energy and the Geological Survey of Alabama.

The initial phase of this study involved both the identification of existing geologic data and published reports covering the Alabama Gulf Coastal Plain and also the compilation and preparation of new and unpublished subsurface data. These new types of data include structure maps, isopach maps, and cross sections of specific sedimentary units in the Coastal Plain sedimentary rock sequence. In addition, a map showing the configuration of the metamorphic and igneous basement complex is being prepared, and the evaluation of the 1ithologic character of these basement rocks is now nearing completion.

The Survey's studies have focused on the southwest part of Alabama which is located on the east flank of the Mississippi embayment of the Northern Gulf Coast Basin. Major structural features that extend into southwest Alabama from eastern Mississippi include the peripheral growth-fault system, the Mississippi Interior Salt Basin, and the Wiggins Uplift. 
The Mississippi Interior Salt Basin is being considered as a possible frontier area for the development of deep geothermal energy resources. However, this area does not display the standard characteristics that are considered to be indicative of areas of high geothermal resource potential -- namely, recent volcanism, hot springs, and near-surface thermal halos. Because these nearsurface indicators are lacking, the basic data come from the drilling of oil and gas test wells. Such data include the logs made from these we11s and the often meager down-hole temperatures taken at the time of 1ogging.

Both the Mississippi Interior Salt Basin and the Wiggins Uplift are quite apparent on a basement configuration map of the area (Fig. 3). The depth to basement, the combined thicknesses of both Cenozoic and Mesozoic sediments, in the Interior Salt Basin area of west-central Washington County is estimated to be greater than 24,000 feet. The Wiggins Uplift is a basement ridge or high located south of the salt basin.

Some correlations can be made between depths to basement and regional gravity maps. The Survey (Wilson, 1975) has compiled a regional gravity map (Fig. 4) from several sources. The Wiggins Uplift is represented by a gravity minimum or low (anomaly 8 on map) which extends from southwest Mississippi eastward into Mobile County, Alabama, thence northeastward up through conecuh County. The Interior Salt Basin, which occupies all of Washington County and parts of surrounding counties, is represented by a gravity maximum or high (anomaly 7 on map). Also, a group of gravity highs or maxima, which are thought to represent deep intracrustal rock masses or intrusions, roughly outlines the extent of thick coastal plain sediments of Jurassic age (anomalies 1 through 5) and also roughly outlines the primary areas of interest for a geothermal-resource potential study. 


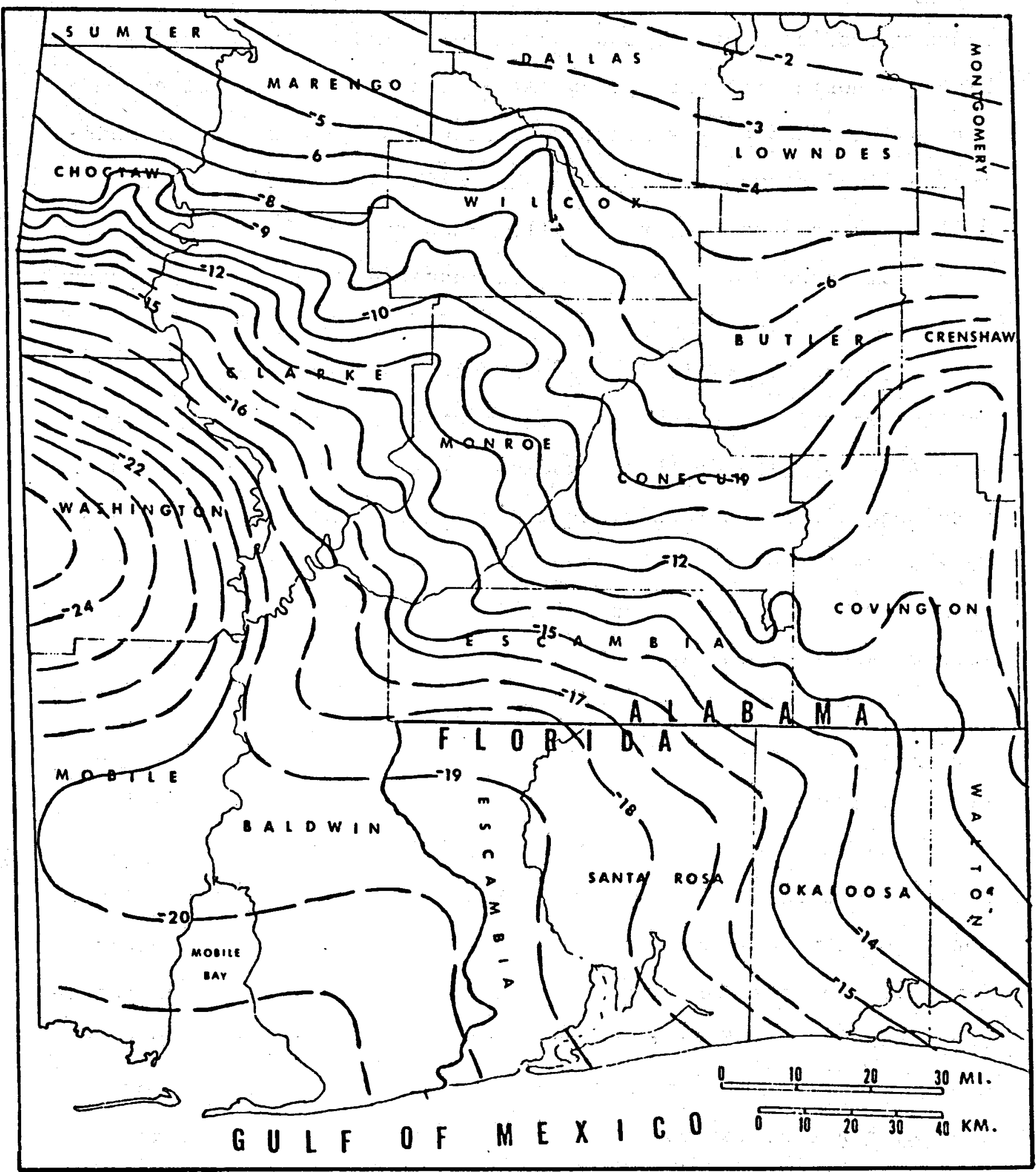

Figure 3: Configuration of the basement surface from well data. Contour values are subsea depths in thousands of feet. (Wilson, 1975) 


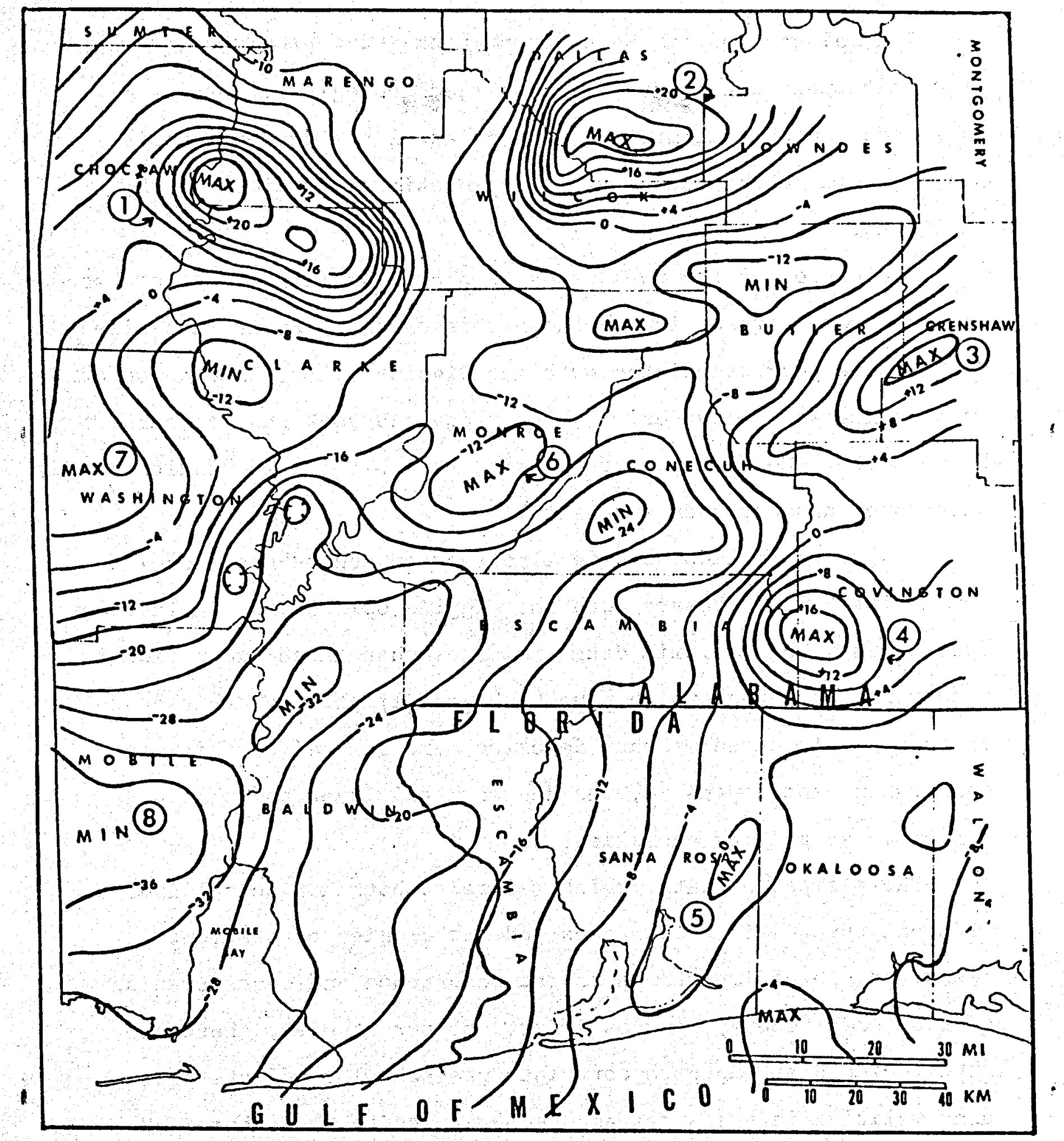

Figure 4: Bouguer gravity map of southwest Alabama and northwest Florida. Contour interval is 4 milligals. (1) Thomasville anomaly; (2) Carlowville anomaly; (3) Rutledge anomaly; (4) Fairfield anomaly; (5) Santa Rosa County. anomaly; (6) Frisco City anomaly; (7) Interior salt basin anomaly; (8) Wiggins uplift anomaly (Wilson 1975). 
Initial studies of the basement rocks have provided information sufficient to prepare a generalized geologic map of the basic rock units, delimit the boundaries of the buried Trassic basin, and mark the boundary of metamorphic alterations in the sediments.

Evaluation of the rock types of the crystalline basement has provided some information on the nature of some gravity anomalies. Much of the rock associated with the Wiggins Uplift is granite or granite gneiss. A few drill holes recovered rock that appears to be mylonite. Correlation of mylonite rock with buried faults or structures has not been successful.

A deep refraction seismic line (Warren and others, 1966) in south Mississippi crosses both the Wiggins Uplift and the Interior Salt Basin. This seismic data indicates that these two regional structural features, which have both greatly affected thicknesses of coastal plain sedimentary deposits, are related to thickness changes in, and depths to, the deep crustal layer, and thus are reflected as gravity anomalies.

These types of data, which relate to both horizontal and vertical changes in thicknesses and lithologies of basement rocks, may be of importance to the occurrence and concentration of geothermal energy sources. Parts of our studies, therefore, have included attempts to correlate geothermal gradients and abnormalities in pressures and temperatures to these basement features.

Data from approximately 1,300 o1l and gas test wells have been inventoried in the Coastal Plain area of Alabama and are presently being evaluated. Basin information such as downhole temperature measurements and drilling mud weights have been compiled. From these data, the Survey now is preparing geothermal 
gradient maps and also isothermal maps of specific horizons.

A structure contour map of the top of the Smackover Formation has been prepared as a part of our assessment study. Depths to top of Smackover range from 8,000 feet in the northeast part of the study area to greater than 18,000 feet in the southwest. A strong northwest-southeast discordance occurs near the center of the map and corresponds to a system of growth faults with displacements of as much as 3,500 feet.

Preliminary results of our data evaluation indicate that the geothermal gradients in the Alabama Coastal Plain are low to moderate, ranging from only about $1^{\circ} \mathrm{F}$ per 100 feet to about $2^{\circ}$ F per 100 feet. Temperatures as high as $300^{\circ} \mathrm{F}$, have been recorded by logging instruments; however, these high temperatures have been found on1y at depths greater than about 17,000 feet. of course, at these great depths it is not surprising that primary porosities are generally very low. The Survey is now attempting to locate areas where geopressured geothermal reservoirs may exist in zones of secondary porosity in consolidated rocks of Jurassic age, mainly carbonates of the Smackover Formation and sandstones of the Norphlet Formation. Cores taken from the Smackover Formation below a depth of 18,000 feet in the Hatter's Pond Field of Mobile County show leached oolite and intercrystalline dolomite porosity from this oil and gas-rich reservoir rock.

Studies of porosity logs, such as sonic and density logs, from oil and gas test wells are presently underway, and there are indications that in some areas of southwest Alabama, geopressured zones exist in the Haynesville Formation of Jurassic age. Favorable sections are composed primarily of interbedded anhydrite and 
shale and lesser amounts of carbonates and sandstones.

of course, the geothermal-resource potential of these deep

zones is dependent upon the presence of saline-water aquifers. Rock cuttings and cores from deep oil and gas test wells are now being studied, as well as electric and porosity logs, in an effort to determine whether or not such aquifers exist at these depths, and if so to outline their areal extent and evaluate their geothermal-resource potential.

In summary, the work on the assessment of the geopressure/ geothermal energy-resource potential of Alabama is well underway. The final analysis of the data should add significantly to the national assessment overview. 


\section{REFERENCES}

Neathery, Thornton L., and Thomas, William A., 1975, Pre-Mesozoic basement rocks of the Alabama Coastal Plain: Gulf Coast Assoc. Geol. Socs. Trans., v. 25, p. 86-99.

Warren, David H., Healy, J.H., and Jackson, Wayne H., 1966, Crustal seismic measurements in southern Mississippi: Jour. Geophysical Research, v. 71, p. 3437-3458.

Wilson, Gary V., 1975, Early differential subsidence and configuration of the northern Gulf Coast Basin in southwest Alabama and northern Florida: Gulf Coast Assoc. Geol. Socs. Trans., v. 25, p. $196-206$. 


\section{Mississippi State Geologic Survey}

DOE State Coupled Program

by

Edwin Luper*

\section{XXVII}

*Mr. Luper could not attend and accordingly, the following brief summary of the Mississippi was presented by Mr. F. C. Paddison. 
The Mississippi State Geologic Survey has issued a report by Mr. Edwin Luper entitled "Final Report - An Investigation of Potential Geothermal Energy Sources in Mississippi" with attached maps. This report documents the development of iso-temperature depths for $70,100,120,150$ and $180^{\circ} \mathrm{C}$ in the southern portion of the State of Mississippi. These maps were developed by the Survey from well logs with bottom hole temperatures in excess of $150^{\circ} \mathrm{F}$ where multiple temperature logs were made and where wells were 2.5 to 3 miles apart.

The report concludes that there are areas favorable for geothermal development and recommends that reservoir studies should follow. 


\section{MISSISSIPPI STATE GEOLOGIC SURVEY GEOTHERMAL PROGRAM}

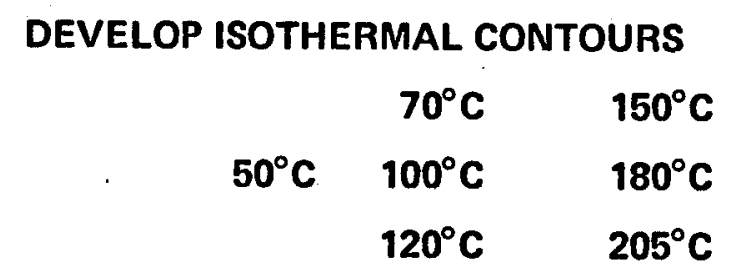

WELL LOGS SELECTED

$t>150^{\circ} \mathrm{F}$

HAD MULTIPLE RUNS

WELL SPACING 2.5 - 3 MILES

MAPS AVAILABLE

$70 \quad 150$

$100 \quad 180^{\circ} \mathrm{C}$

120

CONCLUSIONS

THERE ARE AREAS FAVORABLE FOR GEOTHERMAL. DEVELOPMENT

RESERVOIR STUDIES SHOULD FOLLOW

EDWIN LUPER 


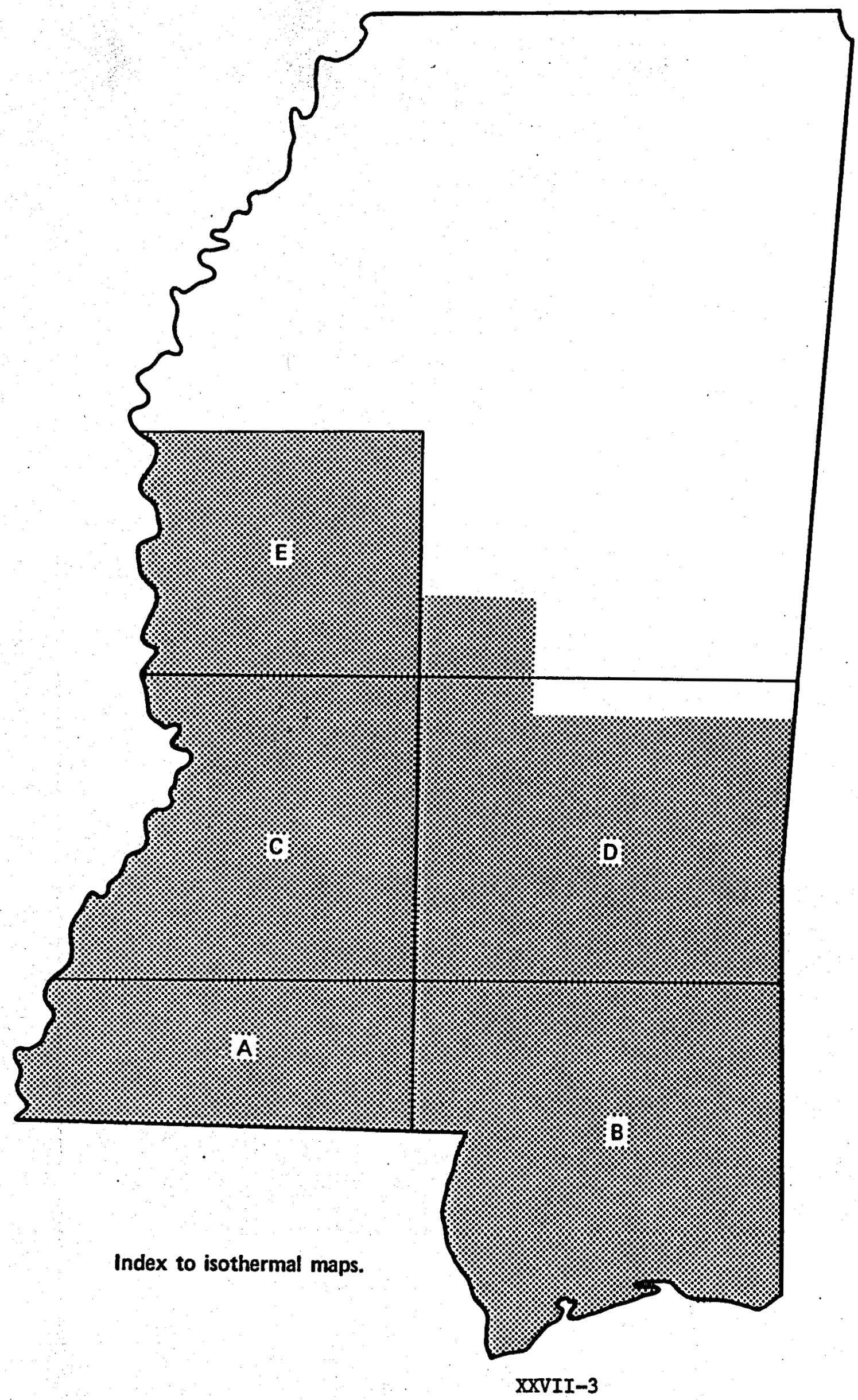


Kansas State Geologic Survey - DOE

State Coupled Program

by

Donald Steeples*

\section{XXVIII}

* Mr. Steeples could not attend and accordingly, a brief summary was presented by Dr. Brophy. The following material was sent by Mr. Steeples for inclusion in these minutes. 
KANSAS GEOLOGICAL SURVFY Environmental Geology Section
1030 A venue " $A$ ". Campus Weet The Univerelty of Kansas Linwrenco, Kanses 68044 013.804 .4001

November 26,1979

Dr. Gerald P. Brophy

Program Manager

DOE/DGE

M/S $3122 \mathrm{C}$

20 Massachusetts Ave., NW

washington, D.C. 20545

Dear Dr. Brophy:

This letter will serve as a quarterly report for Contract DE-ASO7-79ET27204 for the period August 15 - November 15, 1979. The report format follows Article A-1 (Research to be Performed by Contractor) of Appendix $A$ of the contract.

1. A. Revising and updating the geothermal gradient map of Kansas.

As suggested by UURI, the DOE reviewer, data from all individual wells are being transcribed to IBM cards to be later processed into a map. By 15 November, 1979, approximately 60,000 bottom hole depths, temperatures, and elevations had been transcribed from borehole logs to cards. Approximately 5,000 well records remain to be examined. The data will be transformed into a map in the coming months.

1. B. Conducting an aeromagnetic survey of Northwest Kansas.

This survey has been completed and data analyses and reduction will be performed during the coming year.

1. C. Conducting a preliminary correlation of major geologic features with geothermal anomalies.

This task has been delayed pending the completion of transcription of geothermal gradient data onto cards from borehole logs.

1. D. Designing and constructing thermal conductivity probes.

Parts and components are on order for the construction of thermal conductivity probes.

1.

Cooperate with USGS to drill and core two research holes into basement to analyze the hydrothermal potential of the Arbuckle Formation

Bids have been let for these holes and drilling will comence on approximately 1 December, 1979. The location of one of the holes has been changed from Sunner county, Kansas to Miami County, Kansas, because of budgetary constraints. A subcontract with Dr. David Blackwell for heat flow measurements will soon be submitted for DOE approval. 


\section{KANSASSTATE GEOLOGIC SURVEY}

GEOTHERMAL PROGRAM

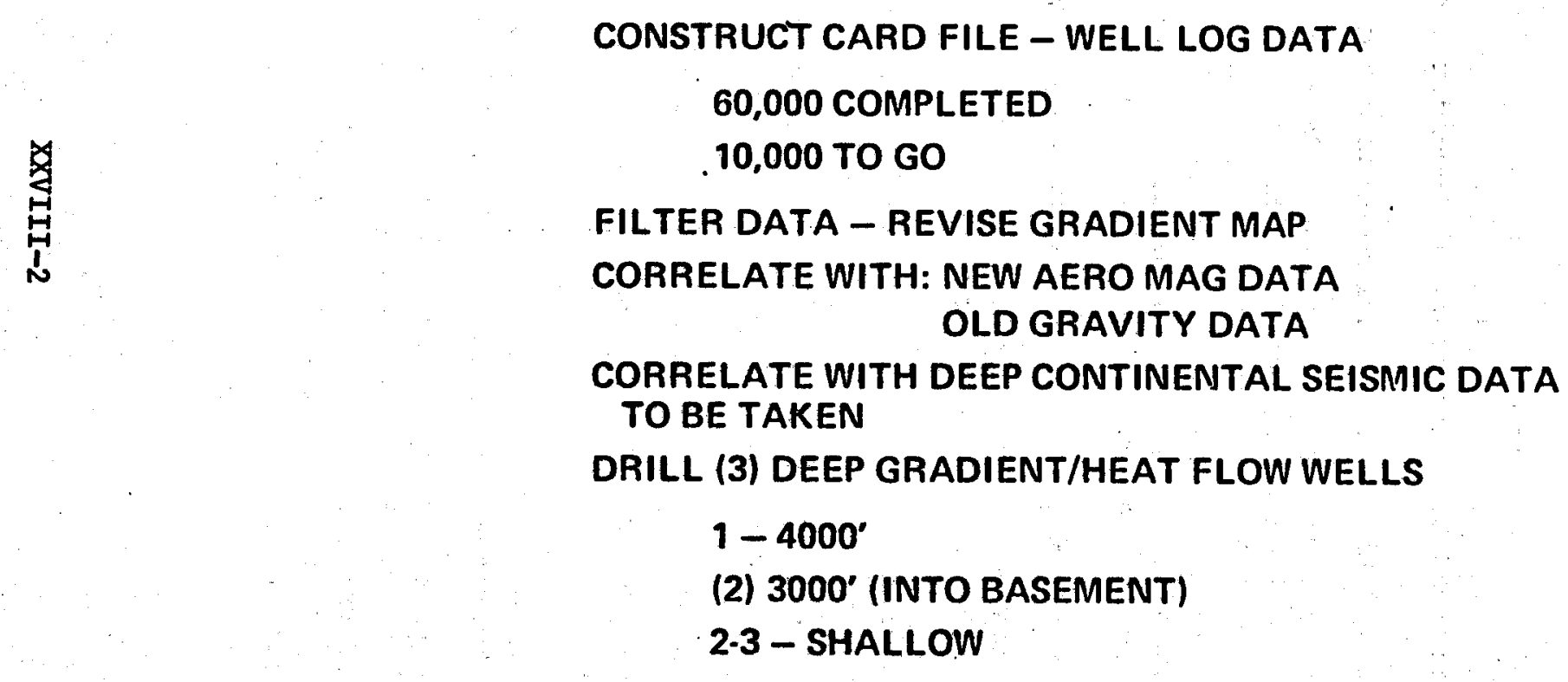

DON STEEPLES 
The Regional Aquifer System

\section{Analysis Program}

by

Gordon D. Bennett USGS/NR - Reston, Va. 


\section{THE REGIONAL AQUIFER-SYSTEM ANALYSIS PROGRAM}

Large increases in withdrawal from the Nation's ground-water reserves are expected to occur during the coming decade. Several factors will contribute to these increases, including sharply increased irrigation, water needs for energy production, water demands of expanding cities, environmental objections to new surface reservoirs, and the desire to establish droughtresistant water supply systems. The impacts of this increased withdrawal will be regional in scope, and an ability to predict and understand these regional impacts is essential for intelligent water management. To address this need the Water Resources Division has established a program of Federally-funded regional ground water studies, the Regional Aquifer-system Analysis Program.

As the term is used here, a regional aquifer system is any areally extensive set of aquifers which are linked in some way. The link may be a direct hydraulic connection among the aquifers, so that pumpage from one has an influence throughout the entire set; or it may be an external hydraulic connection, as in the case of a number of aquifers joined to a single stream system; or it may be an economic link, in the sense that the various aquifers form a common source of supply to some element of the economy; or finally it may simply be a link in the nature of the aquifers, in that they share so many characteristics that is efflcient to study the entire set in a single exercise.

A number of aquifer systems have been identified for study under this program. While each study will be designed to fit the particular problems of the study area, the general approach will be to develop a computer simulation for the overall aquifer system, supported by more detailed simulations of local subregional problem areas.

These simulations will serve a twofold purpose: (1) they will assist in forming an understanding of the natural (prepumping) flow regime, and of the changes brought about in it by human activities; and (2) they will provide a means of predicting hydraulic effects of future pumpage, artificial recharge, waste disposal or other stress, and will thus provide some of the basic information required for water management. In some studies, certain associated effects, such as land subsidence, sea water transgression, or costs of pumping, may form the subject of corallary simulations.

The simulations will be based upon a full assemblage of existing data, and upon such new data as required to fill critical gaps in the available information. In some cases collection of this new data will require extensive field operations. 
Information will also be assembled on the quality of water throughout each aquifer system, again by bringing together all existing information and collecting such field data as required to fill the gaps. An effort will be made to interpret this water quality information in terms of the original flow pattern and the changes that have occurred in response to development, as inferred from the hydraulic simulations. Using the water quality data in conjunction with predicted flow patterns as derived from the hydraulic models, some insight may be gained into future quality problems.

The regional studies are expected to complement and assist the more detailed local studies undertaken through the cooperative program of the Water Resources Division. In particular, each regional analysis should provide a framework--geologic, hydraulic and geochemical--for local investigations. In terms of simulation, the regional model will offer a method of evaluating boundary flows, both lateral and vertical, for local models. In terms of water quality; an understanding of the regional flow pattern, and of the geochemical processes that occur along the flow path, should provide a background for the study of local water chemistry.

Products from each study are expected to consist of a series of reports, beginning with summaries of data as it is assembled, and culminating in interpretive reports including the results of predictive simulations.

The program is expected to cover approximately ten years, and to utilize such advances in investigative technology as may occur over that period. The average length of study will be approximately four years. Three studies were initiated in FY 1978, including the High Plains, the Northern Great Plains and the Central Valley of California. Studies of the Southeastern Carbonate aquifers, the Northern Midwest sandstone aquiers, and the Southwest Alluvial basins were initiated in FY 1979 . Current plans are to initiate studies of the Atlantic coastal plain, the Southeast Coastal Plain and the Central Midwest Carbonates in FY 1980.

A program plan for the Southeast Coastal plain is available from the USGS Water Resources Division. It is entitled "Planning Report for the Southeastern Limestone Regional Aquifer System Analysis", Open-File Report FL-78-516. 


\section{LIST OF ATTENDEES AND INITIAL DISTRIBUTION OF THESE MINUTES}


ATTENDEES

EASTERN GEOTHERMAL TECHNICAL INFORMATION INTERCHANGE MEET ING

October $30,31,1979$

W. A. "Nab" Armfie 1d, Jr

The Armfield Organization

Burton B. Barnes

DOE/DGRM

William F. Barron JHU Center for Metro studies

G. Bennett

USGS/WRD

Rudy Black

DOE/DGE

John Bowman

Columbia LNG Corp.

Gera 1d P. Brophy

DOE/DGE

Wm. B. Chapman

APL/JHU

Mat thew E. Creamer

Wicomico county, MD

Raymond $M$ Coste11o

Burns \& Roe Indust. Service

Samue 1 Dashevsky

VPI

Richard $H$ DeKay

Va.Div. Minerul Resources

Ely Driver

TVA

Robin Dubin

JHU Center for Metro studies
200 West First st.

Winston Salem, NC 27104

12 th and Penna Aves.

Washington, D. C. 20461

Shriver Ha 11

Charles \& 34th sts.

Ba 1timore, ND 21218

National Center

Reston, VA 22092

20 Mass. Ave.

Washington, D.C. 20845

20 Montchanin Rd

Wilming ton, DE 19807

20 Mass. Ave.

Washington, D.C. 20845

Johns Hopkins Rd.

Laure 1, MD 20810

P.O. Box 870

Government Office Bldg.

Sa Iisbury, MD 21801

283 Route 17 South

Paramus, NJ

Geotherma 1 Program, VPI

Blacksburg, VA 24061

P. 0. Box 3667

Charlottesville, VA 22903

$804-293-5121$

P.O. Drawer $\mathrm{E}$

Norr is, TN 37828

Charles \& 34 th Sts.

Baltimore, ND 21218
$615-632-4460$

919-725-8061

202-633-8760

$301-338-7180$

703-860-6904

202-376-4898

302-429-5421

202-376-4898

301-953-7100

301-749-5127

201-265-8710

703-961-6112

$301-338-7180$ 
John Engle

I BS

Larry Falick EG\&G

J.W. Follin

JHU/APL

Larry A Garrett

Columbia LNG Corp.

Richard Gerson

DOE/DGRM

Richard Gleason

VPI

W.D. Gosnold, Jr .

Univ. of Nebraska - Omaha

Joseph Hanny

EG\&G Idaho

Kenneth $G$ Hilfiker

SUNY Buffalo

D.S. Hodge

SUNY Buffalo

R. Wm . Johnson

ORAU-IEA

Martin E Knebe 1

Burns \& Roe Indust.Service

Allan Kover

USGS

Joseph Lambaise

VPI

Claude: S Leffe 1, Jr. JHU/APL

Al Litchfield

Columbia .LNG Corp.
1010 Vermont Ave. N.W.

Washington, D.C. 20011

$202-789-5365$

Washington Analytical

301-840-3000

Service Center

2150 Fields Rd.

Rockville, MD 20850

Johns Hopkins Rd.

Laure 1, MD 20810

20 Montchanin Rd.

Wi lmington, DE 19807

12th \& Penna. Ave.

Washing ton D.C . 20461

Geotherma 1 Program, VPI

Blacksburg, VA 24061

Dept. of Geography \& Geology

Omaha, NE 68182

P.O. Box 1625

Idaho Falls, Idaho 83401

4240 Ridge

Amhurst, NY 14226

716-831-1852

4240 Ridge

Amhurst, NY 14226

$716-831-1852$

Oakridge Assoc. Universities

Oak Ridge, TN $\mathbf{3 7 8 3 0}$

$615-483-8411$

283 Route 17 South

201-265-8710

Paramus, NJ 07652

Nationa 1 Center

Reston, VA 22092

$703-860-6581$

Geotherma 1 Program, VPI

Blacksburg, VA 24061

$703-961-6112$

Johns Hopkins Rd.

Laure 1, MD 20810

301-953-7100

20 Montchanin Road

$302-429-5489$

301-953-7100

$302-429-5253$

$202-633-8760$

$703-961-7169$

402-554-2457

208-526-1894

Wilmington, DE 19807 
John A. Mancus

Delaware Energy office

James C. Maxwe11

LASL/DOE

Robert F. Meier

JHU/APL

Charles Mierek

DOE Region 4

T.L. Nea thery

Geological Survey of Ala.

F.C. Paddison

APL/JHU

Eric A, Peterson

DOE/DGRM

Edward P. Phillips

Worcester \& Wicomico County

Joel Renner

Gruy Federa 1

Wm. L. R. Rice

DOE/DGRM

Kenneth A. Schwarz

Md. Geologica 1 Survey

Morris S'sa lka

DOE/DGE

Wm. Staub

ORAU-IEA

Randa 11 C. Stephens

DOE/DGRM

Albert M. Stone

JHU/APL

Wm. J. Toth

JHU/APL

Ned L. Treat

ORAU-IEA
P.0. Box 1401

Dover, DE 19901

P.O. Box 1663 - MS 983

Los A lamos, NM 87545

Johns Hopkins Rd.

Laure 1, MD 20810

1655 Peachtree St

At lanta, GA 30309

P.o. Drawer 0

University, AL 35486

Johns Hopkins Rd.

Laure 1, MD 20810

12th \& Penna. Ave.

Washing ton, D.C. 20461

P.0. Box 183

Salisbury, MD 21801

2001 Jeff-Davis Hwy .

Arlington, VA 22202

12 th \& Penna. Ave.

Washington, D.C. 20461

Merryman Ha 11, JHU

Baltimore, MD 21218

20 Mass. Ave.

Washington, D.C. 20845

Oak Ridge Assoc. Univ.

Oak Ridge, TN 37830

12th \& Penna. Ave.

Washington, D.C. 20461

Johns Hopkins Rd.

Laure 1, MD 20810

Johns Hopkins Rd

Laure 1, MD 20810

Oakridge Assoc Universities

Oak Ridge, TN 37830
$302-678-5644$

$505-667-6711$

301-953-7100

404-881-2389

205-349-2852

301-953-7100

202-633-8760

301-641-0328

703-892-2700

$202-633-8760$

301-235-0771

202-376-4902

615-483-8411

202-633-8750

301-953-7100:

301-953-7100

$615-483-8411$ 
Tracy Lee Vaught

Gruy Federa 1

Roy von Briesen

JHU/APL

Wm. R. Waldrop

TVA

Kenneth $\mathbf{N}$. Weaver

Md. Geological Survey

Robert Weber

Solar Energetics

Charles Whittle

ORAU-IEA

Kenneth Woodruff

Delaware Geological Survey

James R. Young

Dunn Geoscience Corp.

Kwang Yu

JHU/APL

Receptionist:

Janice (Mrs David) Eisner
2001 Jeff-Davis Hwy.

Arlington, VA 22202

Johns Hopkins Road

Laure 1, MD 20810

P.o. Drawer $\mathbf{E}$

Norris, TN $\mathbf{3 7 8 2 8}$

Marryman Ha 11, JHU

Baltimore, MD 21218

301 s. West st.

Wilmington, DE 19801

Oakridge Assoc. Universities 615-483-8411

Oak Ridge, TN $\mathbf{3 7 8 3 0}$

Univ. of Delaware

Newark, DE 19711

$302-738-2833$

5 Northway Lane North

Latham, NY 12100

Johns Hopkins Rd.

Laure 1, MD 20810

5 18-783-8102

301-953-7100

New Hope Rd.

Berkley Springs, W.Va.

304-258-3299 25411 
EASTERN GEOTHERMAL TECHNICAL INFORMATION INTERCHANGE MEETING

\title{
AGENDA
}

\author{
Tuesday (October 30, 1979)
}

9:00

$9: 10-9: 25$

$9: 25-9: 45$

$9: 45-9: 55$

$9: 55-10: 10$

$10: 10-10: 45$

$11: 00-11: 20$

$11: 20-11: 35$

$11: 35-11: 50$

$11: 50-12: 05$

$12: 05-12: 30$

$1: 30-1: 55$

$1: 55-2: 15$

$2: 15-2: 33$

$2: 33-2: 45$

$2: 45-3200$
Welcome

What's at Berkeley Springs

Introduction

DOE/DGE Overvlew

Future Direction of Direct Heat Applications and Economic Studies

Preliminary Definition of Selected Geothermal Resources, Eastern U.S.

Mid-Atlentic and Southeastern Moderate Temperature Program - Geologic Setting and Targeting Procedures

- Coffee Break -

Hot Dry Rock Eastern Program

ORAU/EAI Program

Geothermal Industrial Use

MITRE Programs

Discussion

$$
\text { - Iunch - }
$$

Windfall Profit Tax - Summary and Status USGS Eastern Geothermal Program

The CrIsfleld Well

Crisfield Well - Transmissivity and Storage Coefficients from Crisfield Data

Geothermal Heating for the Crisfleld High School
APL

Coolfont

R. Black, DOE/RA

G. Brophy, DOE/DGE

M. Skalka, DOE/DGE

J. Renner, Gruy

R. Gleason,

J, Lambiese,

S. Dashevsky, VPI \& SU

J. Maxwe11, LASL

c. Whittle

B. Mikic, MIT
R. Stephens, DOE/RA

A. Kover, USGS/Reston

R. Schwarz, Md/Survey

K. Yu, APL

F. C. Paddison, APL 


\begin{tabular}{|c|c|}
\hline $3: 00-3: 15$ & Campbell Soup - Use of Geothermal \\
\hline $3: 15-3: 30$ & $\begin{array}{l}\text { Lewes, Delaware - Multiple Use of } \\
\text { Geothermal Energy }\end{array}$ \\
\hline & - Coffee Break - \\
\hline $3: 45-4: 00$ & ING Vapor1zation with Geothermal \\
\hline $4: 00-4: 15$ & DoD Eastern Geothermal Program \\
\hline $4: 15-4: 45$ & $\begin{array}{l}\text { Market Assessment, Atlantic Coastal } \\
\text { Plain }\end{array}$ \\
\hline $4: 45-5: 00$ & $\begin{array}{l}\text { Comparison of Potential Geothermal } \\
\text { Resources, Eastern U.S. }\end{array}$ \\
\hline $5: 00-5: 30$ & Discussion \\
\hline $5: 30$ & - Cash Bar - \\
\hline $7: 00$ & - Dinner - \\
\hline
\end{tabular}

M. Knebbel/Burns and Roe

J. Curtin, Lewes Board of Public Works

J. Bowman, Columbla Gas Co.

T. Ladd, U.S. NavFac

W. J. Toth, APL

R. F. Meter, APL

Wednesday (October 31, 1979)

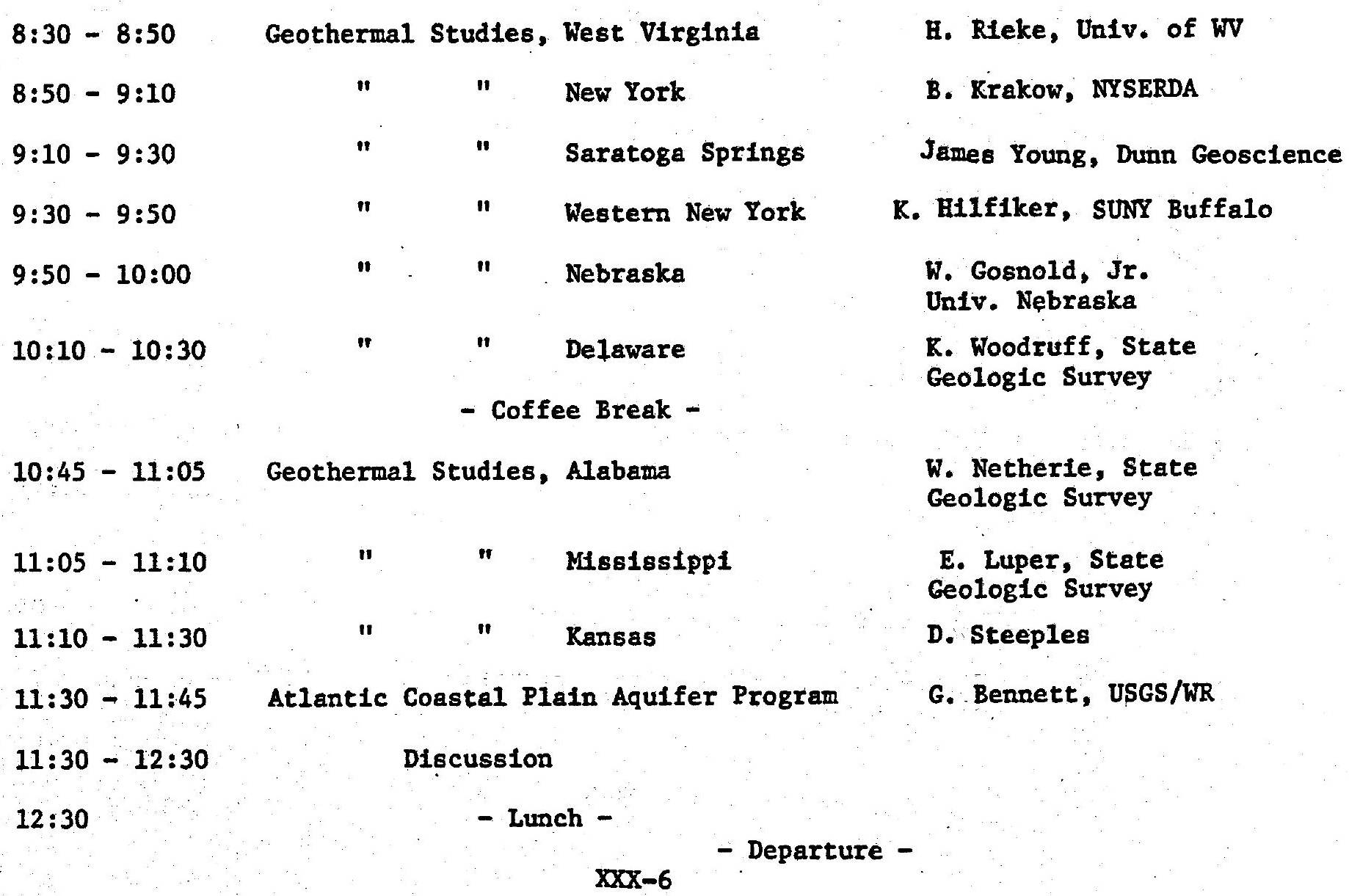


F. Abel

DOE/DGRM

12th \& Penna. Aves., N.W.

Washington, DC 20461

C. Carwile

DOE/DGE, M.S. 3344

12 th \& Penna. Aves., N.W.

Washington, DC 20461

D. H. Clements

DOE/DGRM

12th \& Penna. Aves., N.W.

Washington, DC 20461

B. G. DiBona

DOE/DGE, M.S. 3344

12th \& Penna. Aves., N.W.

Washington, DC 20461

R. A. Gray

DOE/DGE, M.S. 3344

12th \& Penna. Aves., N.W.

Washington, DC 20461

A. J. JelacIc

DOE/DGE, M.S . 3344

12th \& Penna. Aves., N.W.

Washington, DC 20461

D.B.I. Lombard

DOE/DGE, M.S. 3344

12th \& Penna. Aves., N.W.

Washington, DC 20461

R. E. Oliver

DOE/DGE, M.S. 3344

12th \& Penna. Aves., N.W.

Washington, DC 20461

J. W. Salisbury

DOE/DGE, M.S. 3344

- 12th \& Penna. Aves., N.W.

Washington, DC 20461

L. B. Werner

DOE/DGRM

12th \& Penna. Aves., N:W.

Washington, DC 20461

Mr. William C. Livingston

Regional Planner

Department of State Planning

Lower Eastern Shore Regional Office

P.0. Box 183

Salisbury, MD 21801
The Honorable Constance Lleder

office of the Secretary

State Department of Planning

301 W. Preston Street

Baltimore, MD 21201

Dr. Paul 0. Massicot

Administrator

Energy Administration

Department of Natural Resources

James State Office Building

560 Taylor Avenue

Annapolis, MD 21401

Mr. William Reinhardt

State of Maryland

Energy Pollcy Office

Suite 1302

301 W. Preston Street

Balt Imore, MD 21201

Mr. F. W. Evans

Maryland State Energy Office

301 W. Preston Street

Baltimore, MD 21201

Mr. David L. Press

State of Delaware

Executive Department

Delaware Energy office

Dover, DE 19901

Senator Harris B. McDowell III

922 Lovering Avenue.

Wilmington, DE 19806

John P. Curtin

Board of Public Works

Lewes, DE 19958

Dr. John K. Costain

Department of Geologic Sclences Virginia Polytechnic Institute Blacksburg, VA 24061

Dr. L. Glover

Department of Geologic Sclences

Geothermal Program

VPI \& SU

Blacksburg, VA 24061 
H. Herron

Gruy Federal

2001 Jefferson Davis Highway

Arlington, VA 22202

The Honorable Charles A. McClenshan Mayor

Crisfield, MD 21817

Mr. Truman F. Painton

Administrator

Edward W. McCready Hospital

Crisfield, MD 21817

Dr. H. J. Hansen

Maryland Geological Survey

Merryman Hall

Johns Hopkins University

Baltimore, MD 21218

Dr. David Hornbeck

State Superintendent of Schools

International Tower Bullding

857 E1kridge Landing Road

Linthicum, MD 21091

Harold A. Fulton (Mr.)

Superintendent of Schools

Wicomico County

P.0. Box 1538

Long Ave. \& Mt. Hermon Rd.

Sal1sbury, MD 21801

Dr. Eugene M. Karo1

Superintendent of Schools

Somerset County

Prince William Street

Princess Anne, MD 21853

Mr. Douglas A. Harbit

Department of Development

City of Newport News

2400 Washington Ave.

Newport News, VA 23607

Mr. Lowell W. Frederick

Maryland Community Administration

Economic Development

2525 Riva Road

Annapo11s, MD 21401

International District Heating Association

c/o Roberta Houser

5940 Baum Square.

Pittsburgh, PA 15206
James H. Gilliam, Jr.

Secretary

Department of Community Affairs

\& Economic Development

Dover, DE 19901

Mr. J. Harry Michael, Jr.

Chairman

Virginia Coal and Energy Comm. P.0. Box 1070

Charlottesville, VA 22902

Mr. S. Kenneth Schubart

Industrial Development Authority of

The County of Accomack Virginia

P.0. Box 194

Parksley, VA 23335

Mr. Joln Yewell

State Schoo1 Construction Department

International Tower Building

857 Elkr1dge Landing Road

Linthicum, MD 21091

Donald Shaw

VIrginia Division of Leglslative Services

P.0. BoX 3-AG

Richmond, VA 23208

Harold A. Schlenger \& Associates, Inc.

715 Park Avenue

Baltimore, MD 21211

Mr. Paul C. Mears

NASA F11ght Test Center

Wallops Island, VA 23337

Mr. Robert Weber

Solar Energetics

301 S. West Street

Wilmington, DE 19801

Virginia State Office of Emergency Energy Services

310 Turner Road

Richmond, VA 23219

Attn: T. Baylis

J. Johansen

V. W. Banks

Mr. Robert H. Stratemeyer

E-B-L EngIneers, Inc.

Salisbury, MD 21801 
Mr. Ron Schroeder

Lawrence Berkeley Laboratory

University of California

Berkeley, CA 94720

Robert E. Snyder

Completion Technology Co.

4200 Westheimer Rd. Suite 211

Houston, TX 77027

Gregory J. Nunz

P.O. Box 1663 , MS 575

University of California

Los Alamos Scientif Ic Lab.

Los Alamos, NM 87545

William Ogle

Energy Systems, Inc.

P.0. Box 3075

Anchorage, AK 99502

Dr. Lucien N. Brush, Jr.

Professor of Geography and

Environmental Eng11sh

The Johns Hopkins UnIversity

Baltimore, ND 21218

Henry Henderson

The Center for Metropolitan

Planning \& Research

The Johns Hopkins UnIversity

Baltimore, MD 21218

Allen Goodman

The Center for Metropolitan

Planning \& Research

The Johns Hopkins UnIversity

Baltimore, MD 21218

Mr. Preston RIchardson

c/o Board of Education

Snow Hill, MD 21863

Joseph Diblase

Region III

1U.S. Department of Energy

1421 Cherry Street, 10th Floor

Philadelphia, PA 19102

Clayton Nichols

Idaho operations office

U.S. Department of Energy

550 second street

Idaho Falls, ID 83401
Borivoje B. Mikic

Room 7034 B

Massachusetts Institute of Tech.

Cambridge, MA 02139

Harold J. Keohane

U.S. Dept. of Energy

Regional Representative, Reg. I

Analex Bullding - Room 700

150 Causeway Street

Boston, MA 02114

Hugh Saussy, Jr.

U.S. Dept. of Energy

Deputy Reg. Representative, Reg. I. Analex Building - Room 700

150 Causeway Street

Boston, MA 02114

William H. Smith

Deputy

324 East 11th Street

Ransas C1ty, MO 64106

Mary O'Halloran

U.S. Dept. of Energy

Regional Representative, Reg. VII

324 East 11.th Street

Kansas C1ty, NO 64106

U.S. Dept. of Energy

Regional Representative, Reg. II

26 Federal Plaza, Rm. 3206

New York, NY 10007

U.S. Dept. of Energy

Regional Representative, Reg. III

1421 Cherry St., Rm. 1001

Philadephia, PA 19102

U.S. Dept. of Energy

Reglonal Representative, Reg. IV

1655 Peachtree St., N.E.

8th Floor

Atlanta, GA 30309

U.S. Dept. of Energy

Regional Representative, Reg. V

175 West Jackson Boulevard

Room A-333

Chicago, IL 60604 
State Energy Management Board

Executive Building, Suite 203

312 Montgomery St.

Montgomery, AL 36104

Attn: Mr. Edwin Hudspeth

State Energy Office

325 Natural 01d Line B1dg.

Little Rock, AR 72201

Commissioner

Department of Planning E Energy Policy

20 Grand Street

Hartford, CT 06115

State Geologist

Department of Environmental Protection

State Office Bldg., $\mathrm{Rm} .561$

Hartford, CT 06115

Director

Energy Management Administration

108 collins B1dg.

Tallahassee, FL 32304

Bureau of Geology

Department of Natural Resources

903 West Tennessee Street

Tallahassee, FL 32304

Director, State Energy Office

270 Washington, St. S.W., Rm. 615

Atlanta, GA 30334

Attn: Mark Zwicker

Director and State Geolog 1st

Georgia Department of Natural Resources

Earth and Water Division

19 Hunter Street, S.W.

Atlanta, GA 30334

Chairman

Energy Resource Commission

2070 State office Bldg.

Springfield, IL 62706

Chief

Illinois State Geological Survey

Natural Resources Bldg.

Urbană, IL . 61801

Department of Commerce

Energy Group

7th F1oor - Consolidated Bldg.

$115 \mathrm{~N}$. Pennsylvania St.

Indianapolis, IN 46204
State Geolog Ist

Department of Natural Resources

Geological Survey

611 N. Walnut Grove

Bloomington, IN 47401

Mr. M. Van Norstrand

Chatrman

Energy Polfcy Council

Valley Bank Bldg.

300 Fourth Street

Des Moines, IA 50319

State Geologist

Iowa Geological Survey

Geological Survey Blad.

16. West Jefferson St.

Iowa City, IA 52240

Dr. W11l fam W. Hambleton

Director

Kansas Geological Survey

1930 Avenue "A", Campus West

The Untversity of Ransas

Lawrence, RS 66044

Don Steeples

1930 Avenue "A", Campus West

Kansas Geological Survey

The University of Ransas

Lawrence, KS 66044

Kansas Energy office

503 Kansas Avenue

Bm. 241

Topeka, RS 66603

Cha irman

Rentucky Energy Council

Office of the Secretary

Development Cabinet

Captial Plaza Tower

Frankfort, RY 40601

Director and State Geologist

Rentucky Geological Survey

University of Rentucky

307 Mineral Industries B1dg.

120 Graham Avenue

Lexington, KY 40506

Manager

State Fuel Allocation and Conservation office

State House

Augusta, ME 04330 
State Geolog ist

Maine Geological Survey

State Office Bldg., Rm. 211

Augusta, ME 04330

\section{Director}

Division of Standards

Executive Office of Consumer Affairs

One Ashburton Place

11th Floor

Boston, MA 02108

State Geolog1st

Massachusetts Department of Public Works

100 Nashua Street, Rm. 805

Boston, MA 02114

Michigan Energy and Resource

Research Association

728 Executive Plaza

12006 th Street

Detroit, MI 48226

State Geologist

Michigan Department of Natural Resources

Geological Survey Division

Stevens T. Mason Bldg.

Lansing, MI 48926

Minnesota Energy Agency

740 American Center B1dg.

160 East Kellogg Blvd.

St. Pau1, MN 55101

Director

Minnesota Geological Survey

University of Minnesota

1633 Eustis St.

St. Paul, MN 55108

Fuel and Energy Management

Commission

1307 Woolfolk state office B1dg.

Jackson, MS 39205

Director and State Geologist

Misslosippi Geological Survey

2525 No. West St.

Drawer 4915

Jackson, MS 39216

Attn: Edwin Luper

Director

Missour1 Energy Agency

P.0. Box 1309

Jefferson City, MO 65101
Director and State Geologist

Missouri Geological Survey

Division of Geological Survey and Water Resources

P.0. Box 250

Rolla, MO 65401

Office of Energy Coordinator and State Tax Commissioner State office Bldg.

Lincoln, NB 68509

Governor's Council on Energy

$21 / 2$ Beacon Street

Concord, NH 03301

State Geologist

Department of Resources and

Economic Development

James Ha11, Univ, of New Hampshire

Durham, NH 03824

Department of Energy

101 Commerce St.

Newark, NH 07102

State Geologist

New Jersey Bureau of Geology and Topography

P.O. Box 2809

Trenton, NJ 08625

New York Energy Research and Development Agency

Agency B1dg. No. 2

Empire State Plaza

Albany, NY 12223

Geological Survey

NY State Museum and Science Service

Education Bldg.

Albany, NY 12234

Attn: $D r$. Y. W. Isachsen

Dunn Geosclence Corporation

5 Northway Lane

North Latham, NY 12110

Attn: Mr. James R. Dunn

State Geolog 1st

New York State Geological Survey

New York State Education B1dg. Rm.973

Albany, NY 12224

Director

Energy Division

Department of Military \& Veterans Affalrs

215 East Lane street

Raleigh, NC 27611 
Director

Department of Natural and Economic Resources

Office of Earth Resources

P.0. Box 27687

Raleigh, NC 27611

Energy Advisory Council

30 East Broad Street

25th Floor

Columbus, OH : 43215

Division Chief \& State Geologist

Ohio Department of Natural Resource

Division of Geological Survey

Founta in Square, B1dg. 6

Columbus, OH 43224

Governor's Energy Council

500 North Third Street

Harrisburg, PA 17101

Director \& State Geologist

Department of Environmental Resources

Bureau of Topographic and Geological Survey

P.0. Box 2357

Harrisburg, PA 17120

State Energy Coordinator

State Energy Office

State House

Providence, RI 02903

Director

Energy Management office

1429 Senate St.

Columbia, SC 29201

State Geologist

Division of Geology, South

Carolina State Development Board

Harbison Forest Road

Columbia, SC 29201

Director

Tennessee Energy Office

250 Capitol Hill Bldg.

Nashville, TN 37219

Ernest Rebuck

Maryland Water Resources Office

Annapolis, MD 21401
State Geologist

Department of Conservation

Division of Geology

G-5 State Office BIdg.

Nashville, TN 37219

Director, State Energy Office

State Office Building

110 State St.

Montpelier, VT 05602

State Geolog ist

Vermont Geological Survey

University of Vermont

Burlington, VT 05401

Director

Virginia Energy Office

310 Turner Road

Richmond, VA 23219

Dr. H. Rieke

College of Mineral \& Energy Resources

West Virginia University

White Hall

Morgantown, WV 26506

Director

Fuel and Energy Office

$12621 / 2$ Greenbrier St.

Charleston, WV 25311

Director and State Geojogist

West Virginia Geological and

Economic Survey

P.0. Box 879 :

Morgantown, WV 26505

Director

Office of Energy Emergency: Assistance P.0. Box. 5368

Madison, WI 5.3705

Director and State Geolog 1st

Wisconsin Geological and Natural History Survey

UnIversity of Wisconsin

1815: University Avenue

Madison, WI 53706

University of Puerto Rico

Center for Energy and.

Environmenta1 Research

San Juan, PR 00906

Attn: Dr. Ismael Almodovar 